THE ECOLOGICAL IMPACTS OF MINING AT SEAFLOOR MASSIVE SULFIDE DEPOSITS ON MEGAFAUNAL ASSEMBLAGE STRUCTURE AND POPULATION CONNECTIVITY

\author{
BY \\ RACHEL ELIZABETH BOSCHEN
}

A thesis submitted to the Victoria University of Wellington in fulfilment of the requirements for the degree of

Doctor of Philosophy

Victoria University of Wellington

2016 
This thesis was conducted under the supervision of

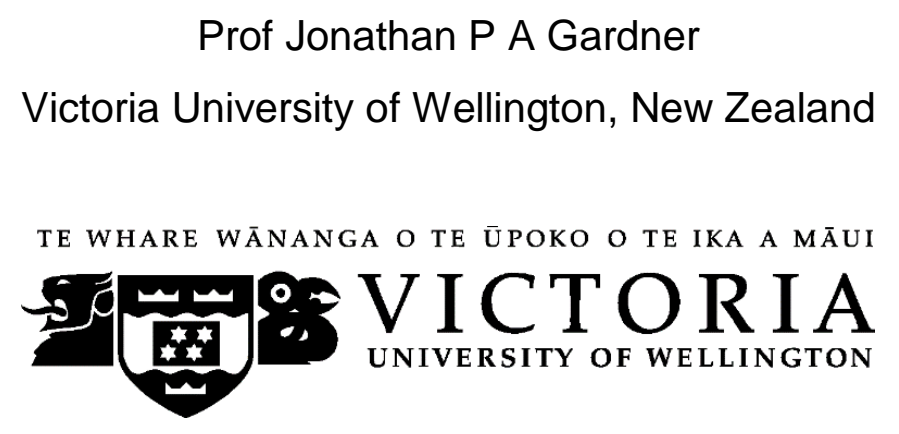

Dr Ashley A Rowden \& Dr Malcolm R Clark

National Institute of Water and Atmospheric Research, New Zealand 


\section{Abstract}

Deep-sea mining is rapidly becoming a reality, yet there are considerable gaps in our knowledge of the seabed assemblages that could be affected by mining activities. Seafloor Massive Sulfide (SMS) mining is expected to remove nearly all organisms in the immediate area and alter the remaining habitat, so that mitigation strategies for SMS mining will most likely need to include the establishment of protected areas to preserve the biodiversity that is lost at mine sites. Prospecting licences have been issued previously for SMS deposits within the New Zealand Exclusive Economic Zone (EEZ), however little is known about the seabed assemblages potentially at risk from SMS mining, particularly with respect to their structure (at multiple spatial scales) and the connectivity of assemblages at different sites. Designing studies to provide this information can be aided by turning to terrestrial, freshwater and shallow marine systems, where the fields of ecological theory, environmental management and conservation theory are better developed (Chapter 1).

Prior to detailed investigations into the assemblage structure and population connectivity of New Zealand SMS deposits, it is essential to understand the global context of SMS mining. This was undertaken through an extensive literature review of SMS deposits, including their geology, seafloor communities, impacts from mining, international and national regulation, and environmental management (Chapter 2).

In order to investigate the large-scale spatial distribution and structure of seafloor assemblages at SMS deposits, three New Zealand seamounts previously licenced for the prospecting phase of SMS mining were surveyed. Video footage from a towed camera was analysed to identify and characterise assemblages, and their association with environmental variation was investigated. Analysis of 249 video samples (each $250 \mathrm{~m}$ in length) distributed amongst the three seamounts indicated that SMS deposits support unique assemblages and that there were strong links between assemblage structure and environmental variation at a range of spatial scales. There was also a complex distribution of assemblages amongst the seamounts, suggesting a network of protected areas would be the most effective method for spatial management. Such networks should include sites that support the unique assemblages found in association with SMS deposits (Chapter 3).

The fine-scale distribution and structure of assemblages at SMS deposits was investigated by using data from a single SMS deposit, Proteus 1 , and comparing it to a Reference Site selected to have similar size and seabed characteristics to the deposit. Video footage from a Remotely Operated Vehicle (ROV) was used to identify and 
characterise assemblages, and their association with environmental conditions. Analysis of 153 video samples (each $15 \mathrm{~m}$ in length) confirmed the existence of assemblages unique to SMS deposits, and indicated that environmental characteristics specific to the deposit are responsible for the observed patterns of faunal distribution. Although five assemblages were shared between Proteus 1 and the Reference Site, six assemblages were unique to Proteus 1. This suggested that the proposed Reference Site would be inadequate on its own in terms of protecting the biological diversity present at the mine site but could contribute to a network of protected areas (Chapter 4).

The issue of connectivity was addressed by examining the genetic connectivity of populations of the endemic hydrothermal vent mussel, Gigantidas gladius. Universal markers, archived material and off-the-shelf DNA extraction kits were used to investigate a cost effective approach. The assessment utilised variation in 586 base pairs of the mitochondrial cytochrome oxidase I subunit (COI) from 150 individuals in seven populations of $G$. gladius. Small sample sizes limited the recommendations that could be made for environmental management; however interpretation of the available sequences indicated panmixia with limited genetic structure and high connectivity amongst populations. Central Kermadec Volcanic Arc populations had particularly high haplotypic diversity and migrant exchange, suggesting they could be important for maintaining regional genetic connectivity and would merit inclusion in seabed protection measures. (Chapter 5).

Establishing protected areas for biodiversity needs to utilise all of the available information. The integrated findings of this thesis highlight the need for a network of protected seabed areas along the Kermadec Volcanic Arc to help mitigate the impacts of any future SMS mining activities. These networks should be highly connected (as determined by genetic connectivity) and include both active and inactive SMS areas to conserve 1) the endemic vent fauna in active areas and 2) the unique assemblages found in both environments (Chapter 6). 


\section{Acknowledgements}

Specific acknowledgements are made at the end of each chapter; here I would like to acknowledge the help and support from individuals regarding the thesis as a whole.

Firstly, I would like to thank my supervisors; Prof Jonathan Gardner at Victoria University of Wellington (VUW) and Dr Ashley Rowden \& Dr Malcolm Clark at the National Institute of Water and Atmospheric Research (NIWA). The guidance, support and wealth of knowledge supplied by my supervisors has been essential to the completion of my PhD. I am also exceedingly grateful for the opportunities provided by my supervisors to participate in research voyages and workshops, and to present my work at international conferences.

I am very grateful to NIWA and VUW for providing the stipend and tuition fee scholarships to support my PhD. My research was conducted as part of the NIWA project 'Deep-sea mining of the Kermadec Arc - Geophysical prospectivity and environmental impacts' funded by the New Zealand Ministry of Business, Innovation and Employment.

I am also grateful to the scientists, technicians and support staff at both NIWA and VUW, not only for providing help and guidance, but for making me feel so welcome. Particular thanks go to the NIWA Invertebrate Collection team for helping me locate samples and for allowing me to dissect hundreds of vent mussels, some of which were rather smelly. I would also like to thank the various external colleagues and collaborators who provided pertinent comments on my research during conferences and workshops. My thesis also benefitted from the constructive comments of my examiners, Dr Wayne Linklater, Prof Thomas Schlacher and Prof Verena Tunnicliffe.

I am lucky to have met many colourful and talented people on my travels, both within New Zealand and overseas. My eclectic circle of friends have entertained and supported me in a multitude of ways during my $\mathrm{PhD}$, for which I am very grateful. I have had some fantastic office and laboratory mates who have encouraged me and indulged my sense of humour.

I would like to thank the medical and healthcare professionals that provided the support needed for me to complete my PhD. In particular I would like to thank the staff at the Wellington Regional Pain Management Service, Victoria University Student Health, and Willis Street Physio. It was a rough ride at times but perseverance paid off.

The biggest thank-you goes to my parents, Kate and Andy, and my sister, Hannah. They have supported me every step of the way; my family is my rock and words cannot say how much I appreciate them. Grandma Clark and Grandma Minchin passed away 
whilst I was completing my PhD but I think they would have been proud. My Dad instilled in me a love of nature from an early age, spending many hours with me sampling and classifying the inhabitants of the family pond and local streams. My sister showed me how it was possible to achieve your potential, despite difficulties, and that the journey is just as important as the destination. My mum is the most inspiring person I know, I am in awe of her resilience and determination and I am immensely proud of how far she has come.

A thesis is a journey with as many ups and downs as the Wellington landscape. But when you do finally reach the hilltop, the view makes the struggle worthwhile. It also provides a vantage point from which to scout out the next series of hills to investigate... 


\section{Table of Contents}

Abstract

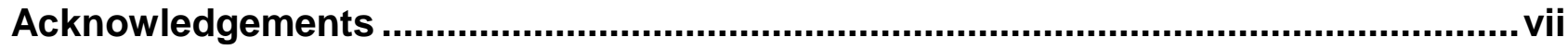

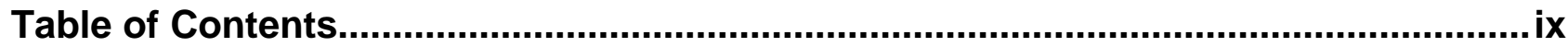

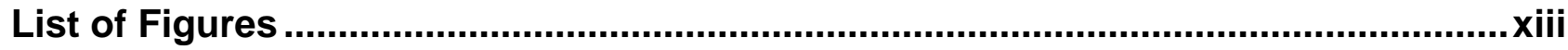

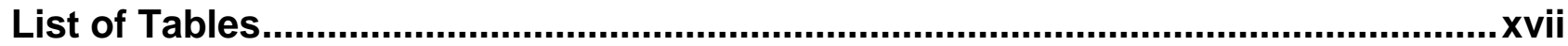

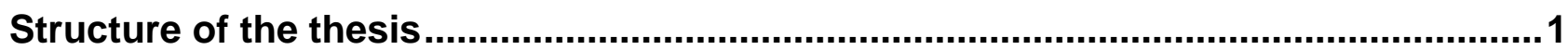

CHAPTER 1. Application of ecological and conservation theory in developing environmental management practices to mitigate the impacts of deep-sea mining ...3

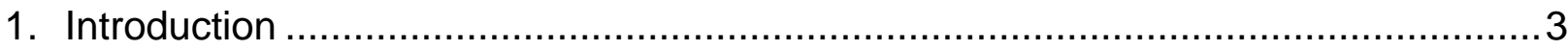

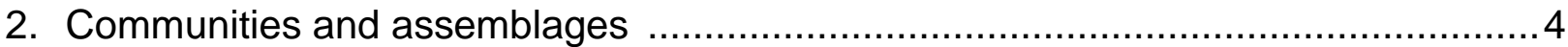

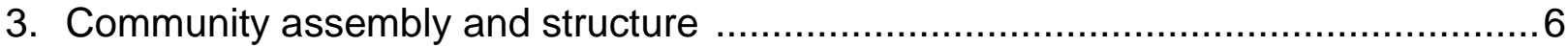

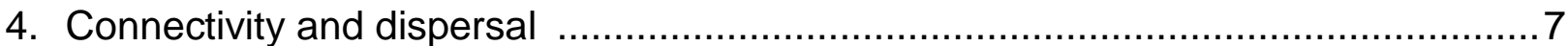

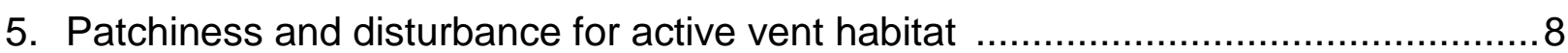

6. Patchiness and disturbance for inactive and non-hydrothermal habitat ...................9

7. Patchiness and habitat fragmentation ........................................................ 10

8. Conservation biology and spatial planning ……….........................................11

9. Developing studies to contribute to the environmental management of SMS deposits within the New Zealand EEZ ..............................................................13

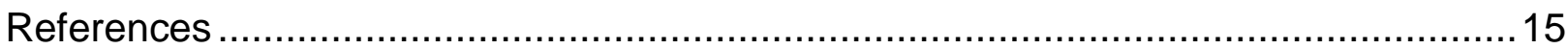

CHAPTER 2. Mining of deep-sea seafloor massive sulfides: a review of the deposits, their benthic communities, impacts from mining, regulatory frameworks and

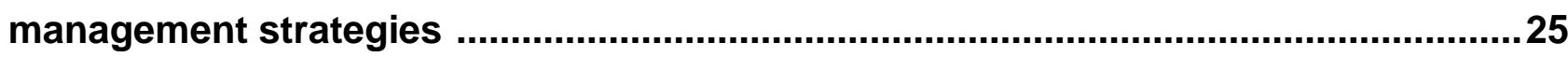

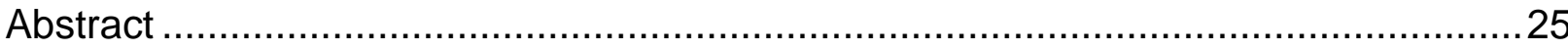

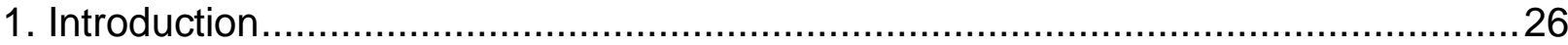

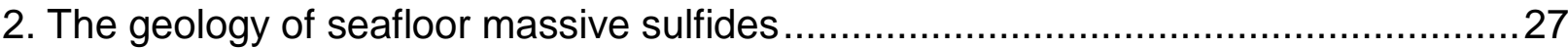

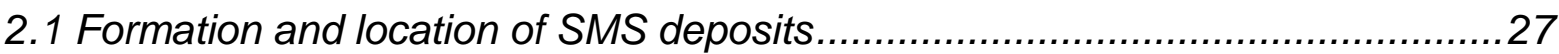

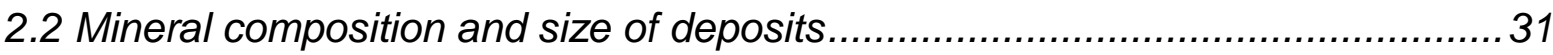

3. The benthic communities of seafloor massive sulfide deposits ...............................32

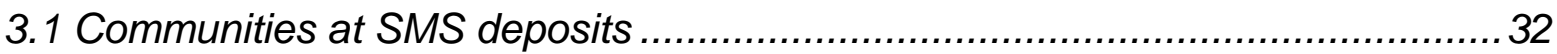

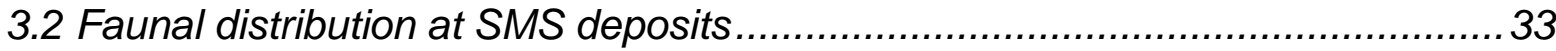

3.3 Global biogeography of SMS communities ................................................ 34

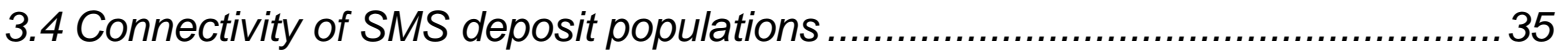

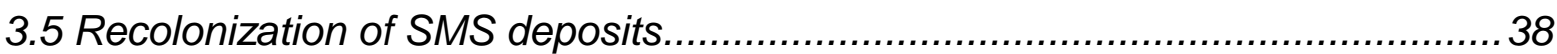




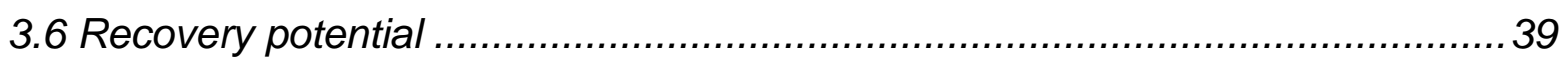

4. Impacts of SMS mining on the benthic community …........................................ 40

5. International and national regulation of SMS mining ............................................ 44

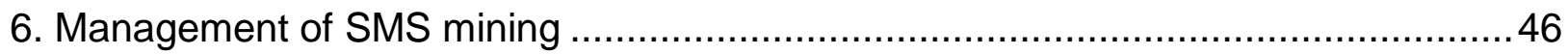

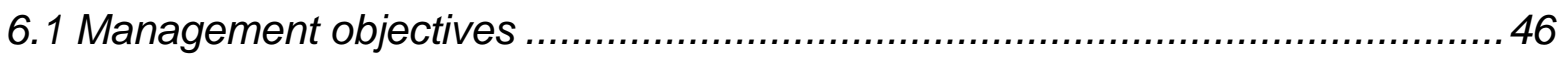

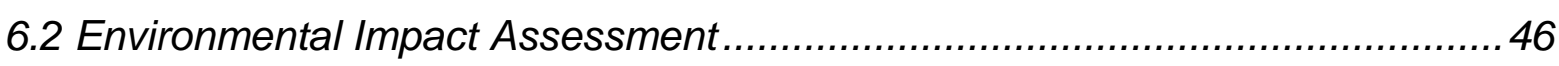

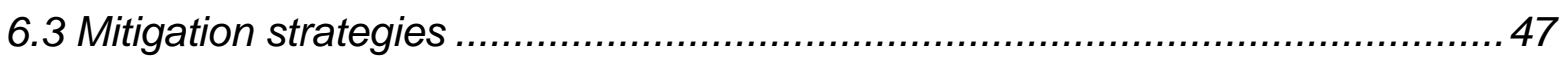

7. Methods to investigate and manage impacts from SMS mining .............................49

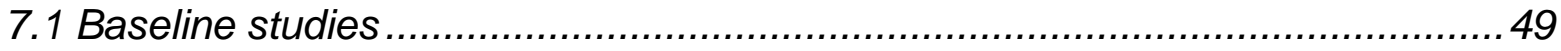

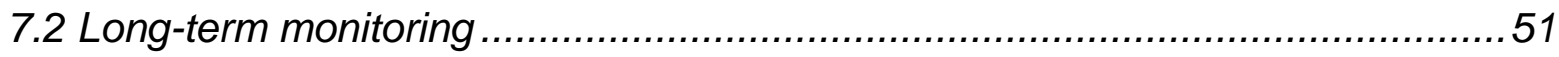

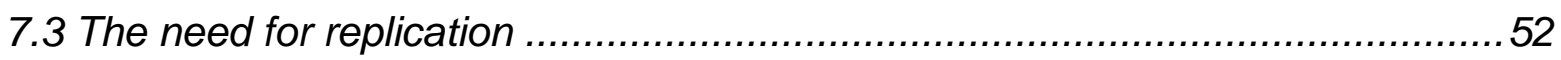

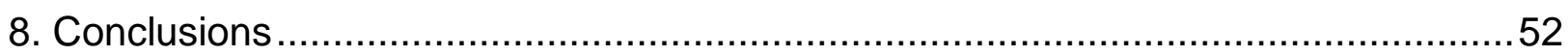

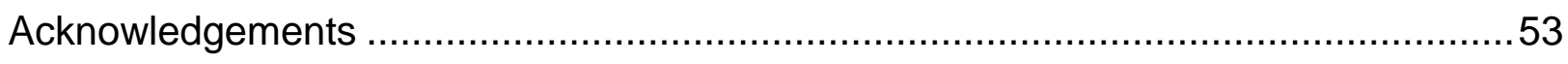

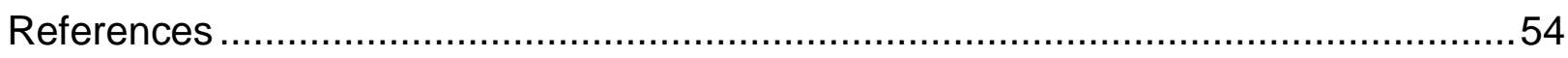

CHAPTER 3. Megabenthic assemblage structure on three New Zealand seamounts:

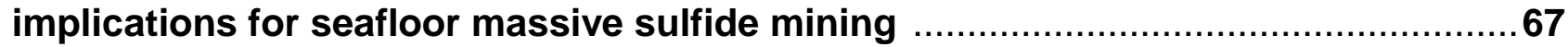

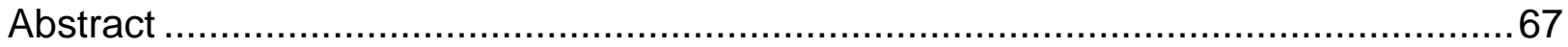

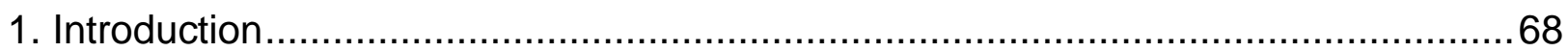

2. Materials and Methods .............................................................................. 70

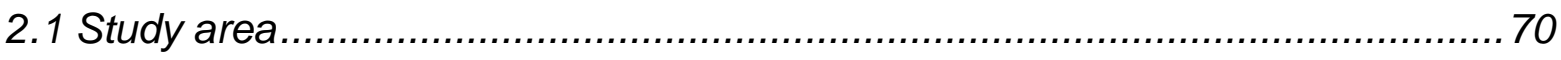

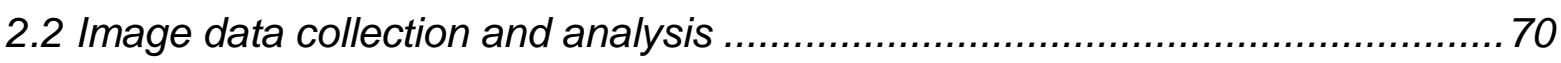

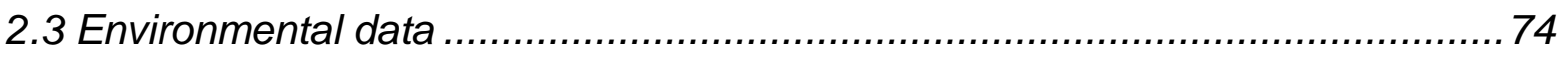

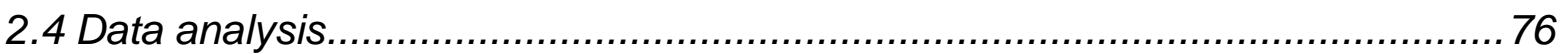

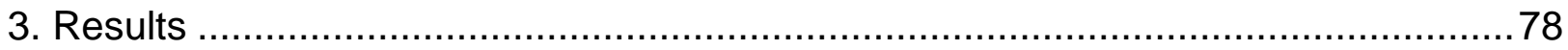

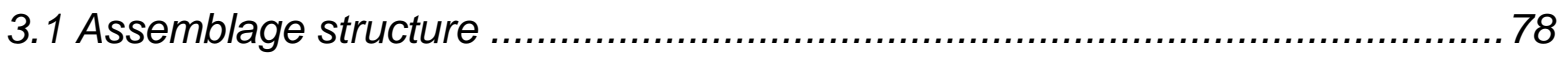

3.2 Environmental drivers of assemblage structure ......................................... 82

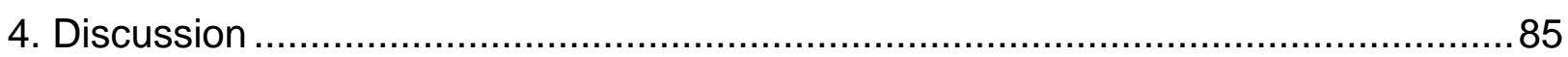

4.1 Assemblage structure and environmental drivers amongst seamounts ............85

4.2 Unique assemblage structure and the environment within seamounts .............86

4.3 Implications for the management of seafloor massive sulfide mining................88

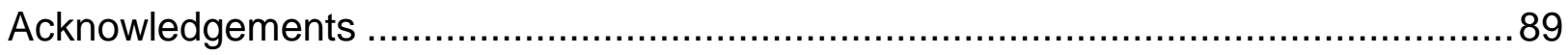

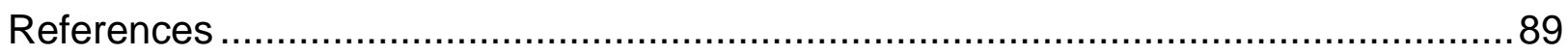

CHAPTER 4. Seafloor massive sulfide deposits support unique megafaunal assemblages: implications for seabed mining and conservation ...............................95

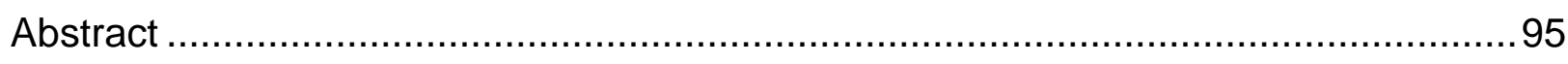




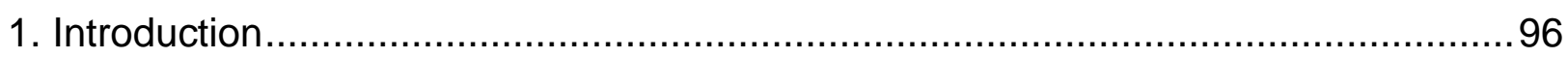

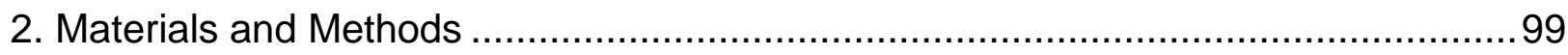

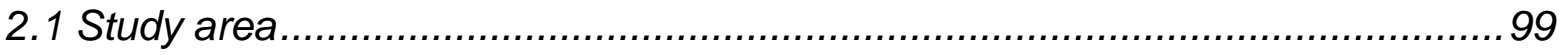

2.2 Image data collection and analysis ........................................................ 100

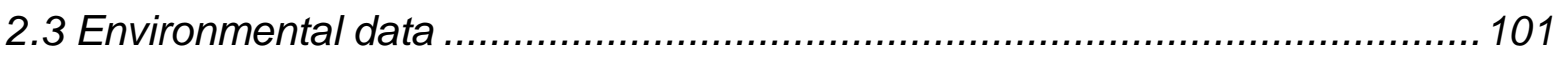

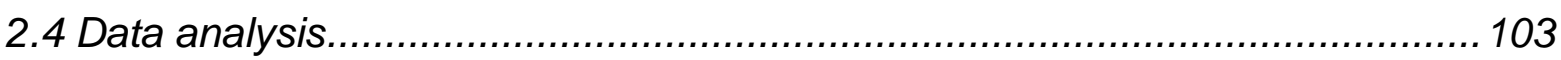

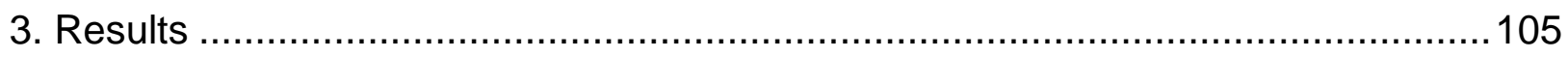

3.1 General seabed characteristics of the study sites ...................................... 105

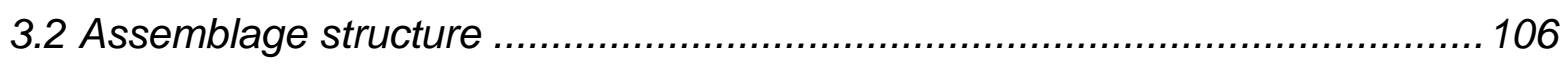

3.3 Environmental drivers of assemblage structure ..................................... 111

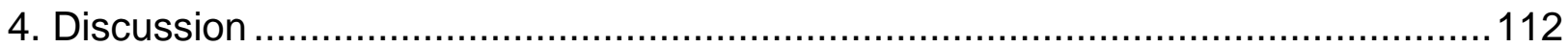

4.1 Structure of assemblages shared between Proteus 1 and the Reference site 112 4.2 Structure of assemblages unique to Proteus 1......................................... 113

4.3 Implications for seabed mining and conservation.......................................117

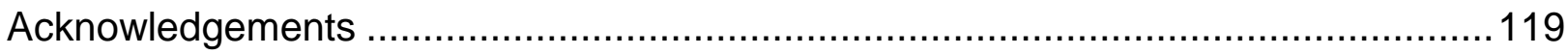

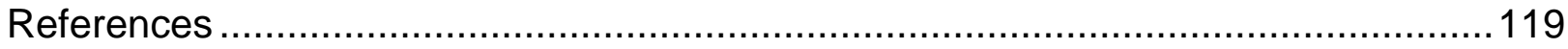

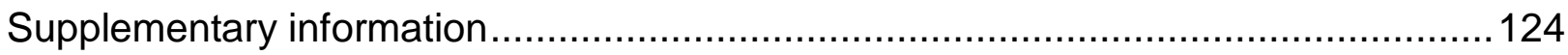

CHAPTER 5. Limitations in the use of archived vent mussel samples to assess genetic connectivity amongst seafloor massive sulfide deposits: a case study with implications for environmental management ......................................................129

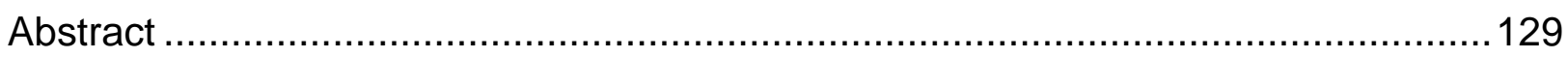

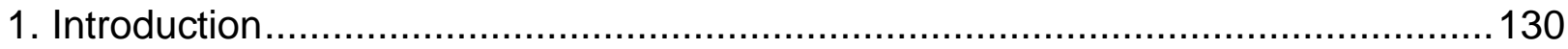

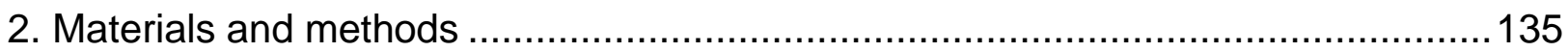

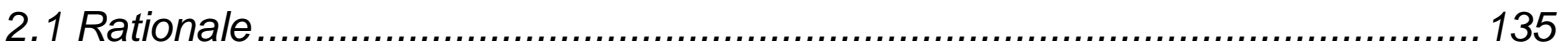

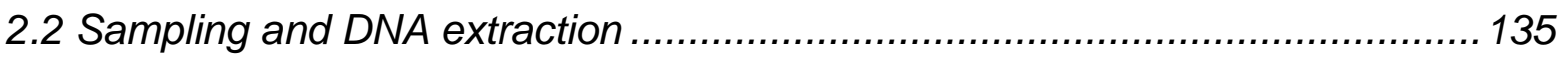

2.3 DNA sequencing - PCR conditions and primers....................................... 136

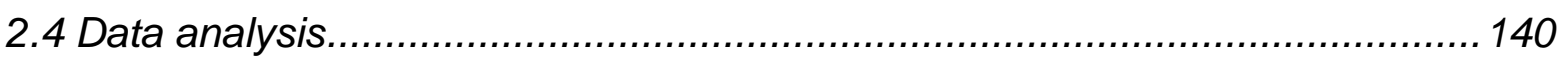

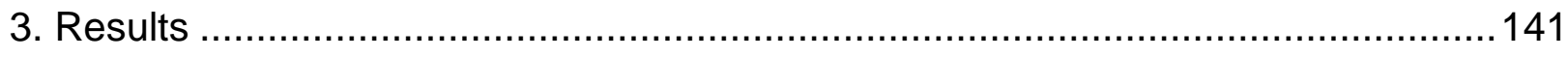

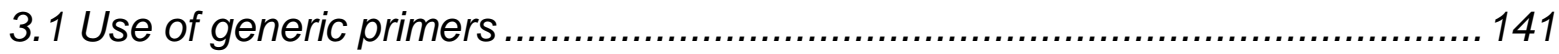

3.2 Quality control tests............................................................................. 142

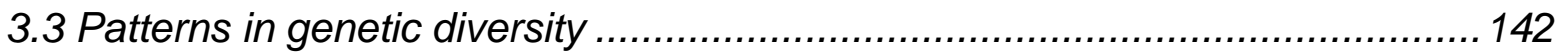

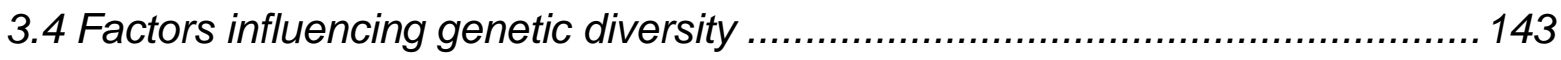

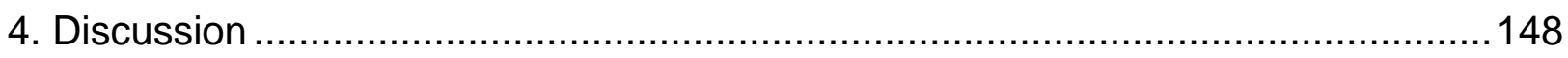

4.1 Population connectivity of Gigantidas gladius .......................................... 148 
4.2 Limitations associated with the use of archived material and generic molecular

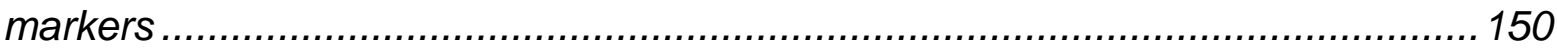

4.3 Implications for the environmental management of seafloor massive sulfide

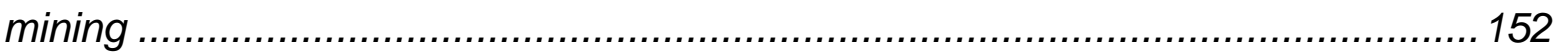

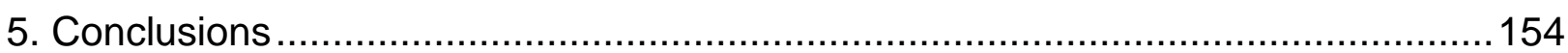

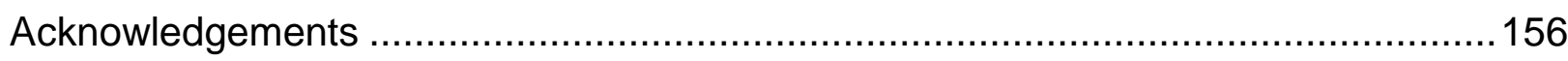

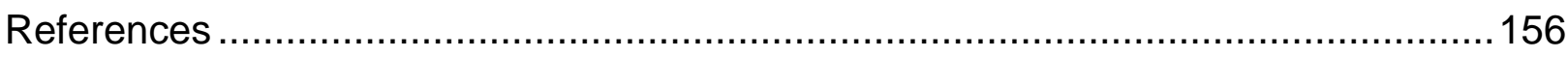

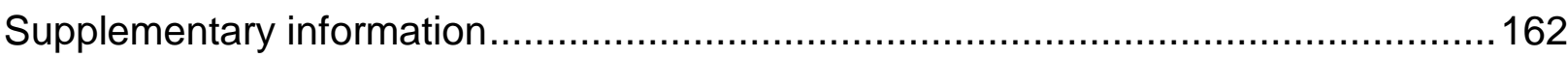

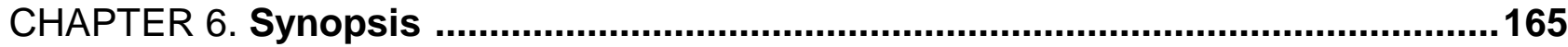

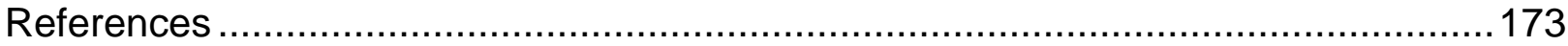




\section{List of Figures}

CHAPTER 2. Mining of deep-sea seafloor massive sulfides: a review of the deposits, their benthic communities, impacts from mining, regulatory frameworks and management strategies 25

Figure 1. Global distribution of SMS deposits. Red circles: active deposits; yellow triangles: inactive deposits. Using data from the InterRidge Database (Beaulieu, 2010). Note that more deposits are known (see Hannington et al. 2011) but their positions are not available to complete this figure.

Figure 2. Map of the global biogeography of hydrothermal vents communities, after Rogers et al. (2012). Abbreviations are CSWP: Central South West Pacific, ESR: East Scotia Ridge, IO: Indian Ocean, KA: Kermadec Arc, MAR: Mid Atlantic Ridge, NEP: Northeast Pacific, NEPR: North East Pacific Rise, NWP: North West Pacific, SEM: South of the Easter Microplate, SEPR: South East Pacific Rise, WP: Western Pacific.

CHAPTER 3. Megabenthic assemblage structure on three New Zealand seamounts: implications for seafloor massive sulfide mining .67

Figure 1. Location of the seamounts Rumble II East, Rumble II West and Brothers in relation to areas licenced for SMS prospecting (purple shading). Insert: regional context of study area including northern New Zealand mainland and Exclusive Economic Zone (purple line)

Figure 2. Distribution of towed-camera transects across the five a priori defined habitat strata (caldera floor (caldera), chimney fields (chimney), seamount cone (cone), seamount flank (flank) and caldera wall (wall)) at the three study seamounts (Rumble II East, Brothers and Rumble II West). .73

Figure 3. Multi-dimensional Scaling (MDS) plot of $200 \mathrm{~m}$ video samples labelled by seamount (A: Rumble II West (RMBIIW), Rumble II East (RMBIIE) and Brothers), a priori defined habitat strata (B: caldera floor (caldera), seamount flank (flank), seamount cone (cone), caldera wall (wall) and chimney fields (chimney)) and SIMPROF assemblages (C: $a-t)$ 79

Figure 4. Digital terrain model maps of SIMPROF assemblage $(a-t)$ distribution over the three study seamounts. Symbols with a black centre indicate assemblages unique to one seamount. Red stars indicate the locations of hydrothermal vent chimney structures from video observations .80 
Figure 5. Distance-based redundancy analysis (dbRDA) plots to give the best possible visualisation of DISTLM results in 2D space for individual environmental variables at Rumble II East (A), Brothers (B) and Rumble II West (C). The coloured dots represent the samples grouped by SIMPROF assemblage. Vectors are proportional to their contribution to the total variation.

CHAPTER 4. Seafloor massive sulfide deposits support unique megafaunal assemblages: implications for seabed mining and conservation .95

Figure 1. Location of study sites, Proteus 1 and the Reference Site, on a digital terrain model of Rumble II West Seamount. Inset: Location of Rumble II West on the Kermadec Volcanic Arc, as indicated by the star. The Arc is represented by the parallel raised areas of bathymetry (in orange) that stretch northeast from New Zealand towards Tonga......

Figure 2. Non-metric Multi-dimensional scaling (MDS) plot of $15 \mathrm{~m}$ video samples labelled by (A) site (Proteus 1 and Reference) and (B) SIMPROF assemblages (I to $\mathrm{XI}$ ). In $2 \mathrm{~B}$, assemblage symbols are as follows; filled upward pointing triangles: hydrothermal vent fauna; filled squares: corals and Dermechinus; filled downward triangles: shrimps; hollow circles: corals, crinoids and sponges; and hollow diamonds: mixed corals. Filled symbols: assemblages only found at Proteus 1, hollow symbols: assemblages found at both Proteus 1 and the Reference Site. ..108

Figure 3. Digital terrain model maps of SIMPROF assemblage (I to XI) distribution over Proteus $1(A)$ and the Reference Site (B). The thick pale grey lines indicate the spatial extent of each site. 109

Figure 4. Distance-based redundancy analysis (dbRDA) plot to visualise DISTLM results in 2-dimensional space for individual environmental variables across the two sites, Proteus 1 and the Reference Site. The coloured symbols represent SIMPROF assemblages (I to XI). Assemblage symbols are as follows; filled upward pointing triangles: hydrothermal vent fauna; filled squares: corals and Dermechinus; filled downward triangles: shrimps; hollow circles: corals, crinoids and sponges; and hollow diamonds: mixed corals. Filled symbols: assemblages only found at Proteus 1; hollow symbols: assemblages found at both Proteus 1 and the Reference site. Vectors length is proportional to their contribution to the total variation (see Table 4).

Figure 5. In situ seabed images including (A) corals, crinoids and sponges assemblages; (B-D) hydrothermal vent fauna assemblages; $(E, F)$ corals and Dermechinus assemblages. Note not all inactive chimneys were colonised $(F)$ and 
inactive chimneys existed in close proximity to active chimneys (B). Arrows indicate Vulcanolepas osheai stalked barnacles (C) and Bathymodiolus sp. mussels (D). Images $A, B, E$ and $F$ are ROV stills, $C$ and $D$ are video frame grabs. Image credit: Neptune Minerals Inc.

Figure 6. Location of $(A)$ hydrothermal vent fauna and bacterial mat, and (B) hydrothermal features within the Proteus 1 site, as determined by video observations.

Figure S1. MDS plot of $10 \mathrm{~m}$ video segments, plotted by site. Dark blue triangles: Proteus 1; light blue squares: Reference Site 124

Figure S2. MDS plot of $10 \mathrm{~m}$ video segments, plotted by SIMPROF assemblage ( $p=$ 0.05). Each different colour/shape of symbol represents an assemblage type .....124

Figure S3. MDS plot of $15 \mathrm{~m}$ video segments, plotted by site. Dark blue triangles: Proteus 1; light blue squares: Reference Site 125

Figure S4. MDS plot of $15 \mathrm{~m}$ video segments, plotted by SIMPROF assemblage ( $p=$ 0.05). Each different colour/shape of symbol represents an assemblage type .....125

Figure S5. MDS plot of $20 \mathrm{~m}$ video segments, plotted by site. Dark blue triangles: Proteus 1; light blue squares: Reference Site 126

Figure S6. MDS plot of $20 \mathrm{~m}$ video segments, plotted by SIMPROF assemblage ( $p=$ 0.05). Each different symbol represents an assemblage type 126

Figure S7. MDS plot of $25 \mathrm{~m}$ video segments, plotted by site. Dark blue triangles: Proteus 1; light blue squares: Reference Site 127

Figure S8. MDS plot of $25 \mathrm{~m}$ video segments, plotted by SIMPROF assemblage $(p=$ 0.05). Each different symbol represents an assemblage type 127 CHAPTER 5. Limitations in the use of archived vent mussel samples to assess genetic connectivity amongst seafloor massive sulfide deposits: a case study with implications for environmental management

Figure 1. Gigantidas gladius sample locations along the Kermadec Volcanic Arc. Solid line indicates the New Zealand EEZ. Grey squares are samples used in this study, white triangles are excluded samples and black areas indicate where prospecting licenses have been issued for SMS mining.... 133

Figure 2. Gigantidas gladius adults and juveniles in situ at Rumble V Seamount, on the periphery of an active hydrothermal vent $(A)$, in clumps on the seabed $(B)$ and within the sediment, predated upon by the asteroid Sclerasterius eructans $(C)$. Images are from the joint New Zealand-USA 2005 NOAA 'Ring of Fire Expedition'. Image credit NIWA 134 
Figure 3. Rarefaction curves for haplotype diversity for all Gigantidas gladius individuals (A) and per population (B); populations 6 and 7 were too small for rarefaction analysis

Figure 4. Haplotype diversity along the Kermadec Volcanic Arc for the seven populations of Gigantidas gladius. Each haplotype is represented by a different coloured slice of the pie chart. ' $n$ ' is the number of individuals sequenced per population, 'Hap' is the number of haplotypes. 146

Figure 5. Minimum-spanning haplotype network for all Gigantidas gladius individuals from the seven populations. Circle size is proportional to the number of individuals with that haplotype, lines indicate relatedness of haplotypes. Line breaks indicate mutational steps in the connectivity between haplotypes

Figure 6. Suggested stepwise plan for using archived biological material in population genetic connectivity assessments with the aim to inform environmental

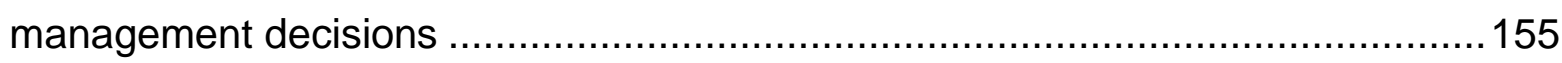

Figure 1. The location of marine boundaries, protected areas, SMS prospecting licenses and seamounts along the Kermadec Volcanic Arc, relative to New Zealand. Main figure: the New Zealand Exclusive Economic Zone (EEZ: green line), the Kermadec Benthic Protection Area (BPA) and the proposed Kermadec Ocean Sanctuary (blue diagonal lines), Tectonic Reach BPA (purple hash), Neptune Minerals Inc. prospecting licence areas (dark brown), and seamounts coded by hydrothermal activity; no hydrothermal activity detected (no activity: pale green triangles) and active (red triangles). The three labelled seamounts (Brothers, Rumble II West, Rumble II East) are the locations for the three studies. Inset: New Zealand mainland and EEZ 


\section{List of Tables}

CHAPTER 2. Mining of deep-sea seafloor massive sulfides: a review of the deposits, their benthic communities, impacts from mining, regulatory frameworks and management strategies

Table 1. Summary of SMS deposit locations and depths using the InterRidge Database (Beaulieu, 2010) Note that more deposits are known (see Hannington et al. 2011) but their positions and physical characteristics (active/inactive, depth) are not available to complete this table.

Table 2. Summary of the potential impacts on the biological environment from SMS mining at Solwara 1, PNG, summarised from Coffey Natural Systems (2008b). Environment classifications: benthic (seafloor); bathypelagic (water column $>1000$ m); mesopelagic (water column $200-1000$ m); epipelagic (water column $<200 \mathrm{~m}$ ). Spatial scales: site $(<1 \mathrm{~km}$ from project location); local $(1-10 \mathrm{~km})$; regional $(>10$ $\mathrm{km})$. Temporal scale: short duration $(<1 \mathrm{yr}$, generally for duration of project); prolonged ( $>1 \mathrm{yr}$ after completion of project).

Table 3. Potential impacts on the benthic community from mining activities, combined from Van Dover (2007) and Van Dover (2011)

CHAPTER 3. Megabenthic assemblage structure on three New Zealand seamounts: implications for seafloor massive sulfide mining .67

Table 1. Distribution of video transects and $200 \mathrm{~m}$ samples and their respective depth ranges, across the three seamounts and a priori defined habitat strata; caldera (caldera floor), wall (caldera wall), cone (seamount cone), flank (seamount flank), and chimney (chimney fields)

Table 2. Hierarchy used to describe substrata, including information on morphology/particle size class and chemical staining; '-' indicates no descriptor...75

Table 3. Taxa composition determined by SIMPER for the SIMPROF assemblages unique to each of the three seamounts; Rumble II East (RMBIIE), Brothers, and Rumble II West (RMBIIW), and shared between seamounts. For assemblages found at multiple seamounts, ${ }^{a}$ shared between Rumble II East and Brothers, ${ }^{b_{f o u n d}}$ at all three seamounts, 'shared between Rumble II East and West. Group similarity indicates the percentage similarity between $200 \mathrm{~m}$ samples within the assemblage group. The cut off for cumulative percentage to the group similarity was $50 \%$. Group o was unique to Rumble II East but only consisted of one $200 \mathrm{~m}$ sample and so could not be characterised by SIMPER analysis 
Table 4. DISTLM Pseudo- $F$ values for the amongst-seamount (All) and withinseamount (RMBIIE, Brothers and RMBIIW) analyses. Displayed are the environmental variable groups selected by DISTLM as part of the best model, '-' indicates the group was available for the analysis but not selected as part of the best model.

Table 5. DISTLM Pseudo- $F$ values for the within-seamount (RMBIIE, Brothers and RMBIIW) analysis when variables were made available to the model individually. Displayed are the environmental variable groups selected by DISTLM as part of the best models, '-' indicates the variable was available for the analysis but not selected as part of the best model. Co-correlates were variables that correlated with another variable at $\mathrm{R}=0.9$ or greater and were subsequently excluded from the analyses. SD: standard deviation.

\section{CHAPTER 4. Seafloor massive sulfide deposits support unique assemblages:} implications for seabed mining and conservation.

Table 1. Substratum hierarchical classification developed from the geological observations to include information on consolidation, broad type, physical and chemical properties. Dead coral and dead vent mussel shells were added to the classification from additional observation in OFOP; '-' indicates no descriptor..... 102

Table 2. Topographic summary of Proteus 1 and the Reference Site. Means and standard deviations (SD) of topographic variables were calculated at native resolution $\left(1 \mathrm{~m}^{2}\right)$. The total area of each site was also calculated. *Northness and eastness were calculated as the cosine and sine of the aspect values respectively, which are unit less. ${ }^{* *}$ Measures of curvature have units of $1 / 100$ ( $z$ units)........... 105

Table 3. Taxa identified during analysis of video segments. Where numbers are included in the name (e.g. Hexactinellidae 1) this indicates a distinct taxon was observed but it could not be identified to species level .................................... 107

Table 4. Taxon composition determined by SIMPER for the SIMPROF assemblages (I to $\mathrm{XI}$ ) at Proteus 1 and the Reference Site. Group similarity indicates the percentage similarity between $15 \mathrm{~m}$ samples within the assemblage group. The cutoff for cumulative percentage to group similarity was $99.9 \%$.

Table 5. DISTLM Pseudo- $F$ values when variables were made available to the model collectively (grouped) or individually (ungrouped). Displayed are the environmental variables and groups selected by DISTLM as part of the best model; '-' indicates the field is not applicable. SD: standard deviation. 
CHAPTER 5. Limitations in the use of archived vent mussel samples to assess genetic connectivity amongst seafloor massive sulfide deposits: a case study with implications for environmental management

Table 1. Gigantidas gladius specimens used for analysis from the NIWA Invertebrate Collection. For latitude and longitude, '-' refers to decimal degrees South and West respectively 138

Table 2. Primers and PCR cycle regimes 139

Table 3. Group structure used for AMOVA tests. Numbers in brackets relate to the group number that populations were assigned to for each AMOVA analysis. KVAN: Kermadec Volcanic Arc North, KVAC: Kermadec Volcanic Arc Central, KVAS: Kermadec Volcanic Arc South

Table 4. Basic population statistics summary information 143

Table 5. The number of migrants per generation between pairs of populations 144

Table 6a. Results for AMOVA grouped as metapopulation 144

Table 6 b. Pairwise testing between populations. Red: significant $P$-value (5\%). Top section of matrix, P-values; bottom of matrix, $\Phi_{\mathrm{ST}}$ 144

Table S1. Gigantidas gladius specimens catalogued in the NIWA Invertebrate Collection but excluded from the analysis. *Fisheries trip locations reported to one decimal place. For latitude and longitude, '-' refers to decimal degrees South and West respectively 162 


\section{Structure of the thesis}

This thesis was completed through publications. Each chapter (excepting Chapter 1 and Chapter 6 ) has been published in a peer-reviewed journal. The relevant publication details are listed below. These publications were often multidisciplinary and as a result were multiauthor. The majority of the data collection, all of the data analysis and all of the manuscript preparation were completed by the primary author, Rachel E Boschen. Additional input to the final manuscripts was provided by the co-authors, as detailed below.

CHAPTER 2. Mining of deep-sea seafloor massive sulfides: a review of the deposits, their benthic communities, impacts from mining, regulatory frameworks and management strategies

Boschen RE, Rowden AA, Clark MR, Gardner JPA (2013) Ocean and Coastal Management 84, 54-67.

- Ashley A Rowden, Malcolm R Clark, Jonathan PA Gardner: editorial suggestions and comments on the final manuscript.

CHAPTER 3. Megabenthic assemblage structure on three New Zealand seamounts: implications for seafloor massive sulfide mining

Boschen RE, Rowen AA, Clark MR, Barton SJ, Pallentin A, Gardner JPA (2015) Feature Article in Marine Ecology Progress Series 523, 1- 14.

- Ashley A Rowden, Malcolm R Clark: involvement in the original survey design and data collection; provided guidance on the statistical analyses and comments on the final manuscript

- Sophie J Barton: provided video observations of the seabed substrata; processed the backscatter data; contributed to developing the substrata hierarchy

- Arne Pallentin: provided assistance with Arc GIS; created the $200 \mathrm{~m}$ track files used for analysis; extracted the topographic values from multibeam data

- Jonathan PA Gardner: editorial suggestions and comments on the final manuscript. 
CHAPTER 4. Seafloor massive sulfide deposits support unique megabenthic assemblages: implications for seabed mining and conservation

Boschen RE, Rowen AA, Clark MR, Pallentin A \& Gardner JPA (2016) Marine Environmental Research 115, 78-88.

- Ashley A Rowden: involvement in the original survey design and data collection; provided guidance on the statistical analyses and comments on the final manuscript

- Malcolm R Clark, Jonathan PA Gardner: editorial suggestions and comments on the final manuscript

- Arne Pallentin: provided assistance with Arc GIS; extracted the topographic values from multibeam data.

CHAPTER 5. Limitations in the use of archived vent mussel samples to assess genetic connectivity amongst seafloor massive sulfide deposits: a case study with implications for environmental management

Boschen RE, Rowen AA, Clark MR, Gardner JPA (2015) Frontiers in Marine Science, 2, 114.

- Ashley A Rowden, Malcolm R Clark: assisted in the original collection of archived material; provided editorial suggestions and comments on the final manuscript

- Jonathan P A Gardner: involved in the original study design; provided guidance on the laboratory work and statistical analysis of data; supplied comments on the final manuscript 


\section{CHAPTER 1. Application of ecological and conservation theory in developing environmental management practices to mitigate the impacts of deep-sea mining}

\section{Introduction}

Anthropogenic pressure on ecosystems is increasing, species extinctions are at an unprecedented level, and with growing human populations, the destruction of natural resources looks set to continue (Pimm et al. 2014). Halting the progress of humanity may not be possible, however measures can be established to mitigate some of the effects and even take steps towards restoring areas that have been damaged. One of the most implemented mitigation strategies is the provision of suitable protected areas; "an area of land and/or sea especially dedicated to the protection and maintenance of biological diversity, and of natural and associated cultural resources, and managed through legal or other effective means" (IUCN 1994, page 7).

The Convention on Biological Diversity (CBD) calls for signatory countries to conserve $17 \%$ of terrestrial environments, and $10 \%$ of coastal and marine areas by 2020 through "ecologically representative and well connected systems of protected areas and other effective area-based conservation measures" (United Nations Environment Programme 2011). However, established protected areas globally only cover approximately $13 \%$ of terrestrial and $3 \%$ of marine habitats, falling sadly short of the CBD goals (Watson et al. 2014). For marine habitats, $3 \%$ is arguably a misleading figure; $94 \%$ of marine protected areas allow harmful activities, such as fishing, meaning that less than $1 \%$ of the ocean is fully protected from human activities (Costello and Ballantine 2015). Many protected areas have been established for socio-economic reasons, with insufficient regard to biological suitability; and where networks of sites have been designated, the connectivity of these networks has often not been assessed (Gaston et al. 2008, Joppa and Pfaff 2009). Designating protected areas when information is limited is challenging; however as the influence of anthropogenic disturbance spreads to the more inaccessible areas of our planet, there will be an increasing need to establish protected areas in environments where ecological information is sorely lacking.

An ecosystem where there is increasing demand for environmental management is the deep sea, where current anthropogenic pressures include the disposal of rubbish, dumping of chemical and radioactive waste, extraction of oil and gas, and other extractive activities such as fishing and deep-sea mining (Ramirez-Llodra et al. 2011). More than 
25000 species have been described from the deep sea to date (Glover et al. 2016); with the deep sea accounting for $90 \%$ of the ocean, and a predicted global total of 540000 marine species (Appeltans et al. 2012), it is expected that many deep-sea species remain undescribed. If appropriate environmental management strategies are not promptly established, we risk losing deep-sea species before they have been discovered. Unfortunately the remoteness of the deep sea and associated high cost of study has led to a relative paucity of information, particularly regarding disturbance and recovery dynamics.

One of the challenges facing environmental managers is deep-sea mining. There are multiple mineral resources currently of interest, including polymetallic nodules, polymetallic seamount crusts and hydrothermally-formed seafloor massive sulfides (SMS). The latter resource will be mined in the southwest Pacific before 2020 (Baker and Beaudoin 2013), with the first commercial deep-sea mining licence issued to Nautilus Minerals Inc. in 2011 (Nautilus Minerals Inc. 2016). Despite being discovered in 1977 (Corliss et al. 1979), current information on the hydrothermal environment and associated communities is arguably inadequate to inform suitable mitigation strategies. New vent sites, communities and species are still being discovered and we have limited appreciation of the community structure and biological connectivity amongst vent sites, information that is essential for establishing a coherent network of protected areas. The fields of ecological and conservation theory are better developed in terrestrial, freshwater and shallow marine systems; by seeking to apply models and theories from these environments we can broaden our understanding of potential management strategies for the deep sea and direct resources intelligently towards future research.

\section{Communities and assemblages}

Studies in ecology are complicated by a lack of consistent terminology; for starters, there are no 'standard' definitions of community, population or ecosystem (Jax 2006). One of the earliest and most widely accepted definitions of community is from Whittaker, who defines a community as a combination of "populations of plants, animals, bacteria, and fungi that live in an environment and interact with one another, forming together a distinctive living system with its own composition, structure, environmental relations, development, and function" (Whittaker 1970, p1). However, not every community contains all of these elements, for example deep-sea communities occur below the euphotic zone and in the absence of sunlight, do not support plants or other photosynthetic organisms. Later definitions capture the essence of Whittaker's concept but are applicable to a wider range of environments, such as that of Holyoak, where a community is defined as "the individuals 
of all species that potentially interact within a single patch or local area of a habitat" (Holyoak et al. 2005, p8). Based on this definition, communities at deep-sea habitats, such as a seamount flank or hydrothermal vent chimney, would consist of all species present, from bacteria through meio-, micro-, macro- and megafauna. As it is not possible to census every species in a community, generally only a subset of species present are considered; such subsets are termed 'assemblages'. The use of 'assemblage' is also seen as being 'neutral', without implications of specific relationships between the organisms present (Allaby 1998). Despite 'assemblage' being the more technically correct term for many ecological studies, the majority of theory discusses species groupings in terms of 'communities'.

The communities colonising SMS deposits licensed for mining activities have been poorly studied; only one published paper specifically addresses the community structure of a licenced deposit (Collins et al. 2012). However, four decades of research on hydrothermal vent communities can inform our expectations of the general ecology of SMS deposits. Deposits provide three broad habitat types; hydrothermally active areas, hydrothermally inactive areas, and non-hydrothermal hard substrata, such as lava and volcaniclastic rock (Van Dover 2011). Different communities colonise these habitats; active areas are colonised by a vent community that is reliant on hydrothermal activity to survive and cannot exist away from active vents (Van Dover 2000). Both inactive SMS areas and non-hydrothermal hard substrata are colonised by a peripheral community of sessile suspension-feeders (Galkin 1997, Collins et al. 2012), which can develop large populations in close proximity to active vents by utilising the additional food sources, such as bacterial mat dislodged from the vents (Erickson et al. 2009). Inactive areas also present the possibility of a further community adapted to the weathered sulfide environment of inactive deposits (Van Dover 2011). Each of these communities are vulnerable to mining disturbance, with mining activities expected to remove all large organisms and their habitat in the immediate area to be mined, along with downstream effects from turbidity plumes (Van Dover 2011, 2014). In order to develop suitable mitigation strategies for seabed mining, it is important to understand how these very different communities assemble and how they are structured, including relationships with the SMS deposit environment. 


\section{Community assembly and structure}

Community assembly is the construction and maintenance of local communities through sequential arrival of potential colonists from an external species pool (Drake 1991, Warren et al. 2003). Historically, there were two opposing views of community assembly; either assembly occurred through coincidental association resulting from fluctuation in immigration of colonists and environmental variation (Gleason 1926); or communities formed 'super-organisms' assembled through discrete units that eventually together form a stable climax (Clements 1936). The concept that communities formed from discrete assemblages was later disputed (Whittaker 1951, 1956) and it became more generally accepted that the degree to which a community structures depends on many factors, including the number of species in the regional pool, their dispersal ability, niche overlap and the environmental variability (Gravel et al. 2006).

Multiple theories have been developed to explain the patterns observed in community structuring. These include the concept of 'assembly rules' (Diamond 1975a), which determine how communities form as subsets of species from a larger pool of those species available within the region. One of the first models of assembly was dubbed 'the island paradigm', which stems from MacArthur and Wilson's 'neutral' equilibrium theory of Island Biogeography (MacArthur and Wilson 1967). In this model, the number of species in a habitat is solely determined by the balance between the colonization rate of species from a species pool and the local extinction rate of a species. The model assumes immigrants are provided externally (e.g. from the mainland) and that adjacent patches (or islands) do not exchange immigrants.

Whilst the island model was applicable in the case of off-shore islands, it is too simplistic to account for the exchange of migrants between multiple habitat patches within a region, where there is no single supply of immigrants. This resulted in the development of the metacommunity model, when a collection of local patches undergo community assembly through dispersal of species between patches (Wilson 1992, Leibold et al. 2004). Complementing the model of metacommunities was that of metapopulations; where a group of populations in a region are spatially separated but are connected through the movement of individuals amongst populations in different habitat patches (Levins 1969, 1970, Hanski and Gilpin 1991). Although individual populations may become extinct in a region, the balance between patch extinction and recolonization allows the population as a whole (the metapopultion) to persist in a region, even though it may not be present in any one patch at any one time (Kareiva and Wennergren 1995). 


\section{Connectivity and dispersal}

The concepts of metapopulations, metacommunities and patch dynamics are particularly important when considering the community structure of habitats at risk from SMS mining, such as seamount-hosted hydrothermal vents. These generally occur along tectonic plate boundaries, so that a single source of immigrants, as in the concept of one mainland and many islands, is unlikely. Marine organisms with planktonic larval stages can disperse further than terrestrial organisms by orders of magnitude (Kinlan and Gaines 2003), whilst the influence of current flow on larval dispersal means some habitat patches may contribute more immigrants to the metacommunity than others. This forms the basis of source-sink dynamics; populations that experience a net out-flow of individuals are known as source populations, whilst populations that cannot be sustained without a source of migrants are sink populations (Pulliam 1988). Dispersal amongst these populations is the 'glue' that keeps metapopulations together (With 2004).

The connectivity of vent communities has largely been studied using genetic methods, although there has also been considerable development in the use of biophysical models to estimate dispersal distances of deep-sea larvae (Hilário et al. 2015). Population genetics studies have identified four general models of connectivity and dispersal amongst populations: 1) the island model, where gene flow occurs without geographical bias; 2) the isolation by distance or stepping-stone model, where genetic differentiation increases with geographical distance; 3) segment-scale divergence, where genetic differentiation is associated with offsets between ridge segments; and 4) ridgescale isolation, where isolation by distance occurs along a ridge axis (Vrijenhoek, 1997, 2010). There is also the concept of panmixia, where all individuals in a metapopultion are potential partners, resulting in high gene flow and no significant genetic differences between populations. The two most common models within vent communities are the isolation by distance model and panmixia; for the management of deep-sea mining it is essential to know which of these models are operating for a species (Boschen et al. 2016a). In the case of panmixia, removal of any given population through mining disturbance may have little effect on the genetic diversity and health of the metapopulation. In the case of isolation by distance, increasing genetic differentiation with distance means distant populations are less likely to exchange larvae and so become genetically differentiated. The maintenance of populations existing under the isolation by distance model may be reliant on a stepping-stone supply of larvae from vent sites along a ridge, meaning a site farther down the chain could be starved of recruits if an intermediary site is removed. To maintain the genetic diversity and physical distribution of the 
metapopulation, it is important to identify source populations in the chain to ensure these populations are not lost through mining activities (Boschen et al. 2016a). It should also be considered that larval supply from distant communities may only be possible with the appropriate hydrodynamic regime; in the case of seamount-hosted vents, there is greater occurrence of larval retention, resulting in high local recruitment but reduced colonisation potential for new vent habitat, both within and amongst neighbouring seamounts (Metaxas 2011).

\section{Patchiness and disturbance for active vent habitat}

Seamount-hosted hydrothermal communities are of particular concern for seabed mining, as they tend to have a patchy distribution along arc and back-arc systems, with restricted larval dispersal between sites compared to along-axis vent communities (Metaxas 2011). Such communities include those colonising the first SMS deposit to be issued a commercial mining licence, Solwara 1, offshore of Papua New Guinea (Nautilus Minerals Inc. 2016). Seamounts occur as islands on the seafloor; SMS deposits occur as patches on these seamounts; and within the deposits themselves, hydrothermal activity is not homogenously distributed, resulting in a mosaic of hydrothermally active and inactive areas. Even within a single active chimney complex, variation in fluid flow and character across the complex will result in patchy microhabitats (Sen et al. 2013, Podowski et al. 2010, Podowski et al. 2009, Marsh et al. 2012, Sarrazin et al. 1999, Cuvelier et al. 2009). The nested character of habitat heterogeneity results in a complex distribution of SMS communities, involving multiple spatial scales; such complexity should be considered when developing environmental management strategies for SMS mining.

Of the communities at SMS deposits, those colonising active hydrothermal vents have received the greatest amount of research attention (Van Dover 2011, 2014). These communities are typified by low diversity but high biomass (Grassle 1985), with rapid growth rates of individuals (Lutz et al. 1994); all characteristics of communities in disturbed environments, or 'r-selected' species (Pianka 1970). In general, disturbance tends to increase spatial heterogeneity at multiple spatial scales (Wu and Loucks 1995, Halford et al. 2004), with the mosaic of patches formed from disturbance experiencing succession along alternative trajectories and at different rates, further enhancing patchiness, so that adjacent patches are at different stages of succession (Walker and del Moral 2003). Ephemeral habitats can also lead to heterogeneity over time; wood-rotting fungi cause their habitat patch to rot away (Siitonen et al. 2005) and epiphytic mosses find their tree ultimately falls over (Snall et al. 2005). 
At the micro-distribution scale, fluctuations in hydrothermal fluid flow and character can alter the habitat over short timescales, resulting in the loss of some patches and the creation of others (Sarrazin et al. 1997, Sen et al. 2014). Individual chimneys in a complex can wane and eventually become inactive; chimneys can collapse and re-grow; some inactive orifices may even regain hydrothermal activity as fluids flux (Sarrazin et al. 1999). Whole vent fields can be paved over by lava during volcanic eruptions, resulting in catastrophic loss of habitat (Lutz et al. 1994, Tunnicliffe et al. 1997, Shank et al. 1998).

Even within the same environment, community structure can diverge amongst locations as a result of stochastic variation in the history of species arrivals (Samuels and Drake 1997, Belyea and Lancaster 1999, Fukami et al. 2005, Chase 2003). This means the species composition of colonisers at a newly disturbed site could be different from those previously inhabiting the site, even with an identical regional species pool. The composition of colonisers for newly formed vent habitat can depend on larval supply; if catastrophic eruption removes all of the vent communities in the immediate vicinity, colonisers can be from more distant vent communities, resulting in a shift in community composition (Mullineaux et al. 2010).

Patchiness of communities can also result from biological interactions, with competition leading to limited membership of a community and resource partitioning (Schoener 1974). The influence of competition on patchiness can also be observed within vent communities, where temperature and sulfide tolerances determine the ability of certain vent gastropods to compete for vent habitat on active chimneys (Podowski et al. 2010, Podowski et al. 2009, Sen et al. 2013). Ultimately, the succession of organisms that colonise vents is not reliably directional; it is influenced by a complex array of abiotic and biotic variables exhibiting spatial and/or temporal heterogeneity, resulting in a mosaic of communities from various successional stages (Sarrazin et al. 1997, Shank et al. 1998).

\section{Patchiness and disturbance for inactive and non-hydrothermal habitat}

The other two habitats at SMS deposits, inactive sulfide structures and non-hydrothermal hard substrata, support very different communities from those found at vents (Van Dover 2011, 2014). Both inactive areas and non-hydrothermal hard substrata can support an array of generally sessile, long lived and slow growing suspension-feeders, including sponges, hydroids, corals, anemones, squat lobsters, ophiuroids and holothurians (Galkin 1997, Van Dover and Hessler 1990, Collins et al. 2012). These taxa take advantage of the 
elevated hard substrata provided by inactive SMS deposits, but are not restricted to inactive areas; many are also found at neighbouring elevated non-hydrothermal hard substrata (Van Dover 2011). However, these organisms do tend to occur in greater densities in close proximity to hydrothermal activity, demonstrating patchy distributions over 10's to 100's of meters (Arquit 1990, Sudarikov and Galkin 1995, Galkin 1997). Very little research has been conducted on the communities colonising inactive and nonhydrothermal substrata proximal to hydrothermal vents; so little in fact, that there is still the possibility of a community unique to the weathered sulfide environment that has yet to be discovered (Van Dover 2011).

The hydrothermally inactive sulfide habitat could be viewed as a boundary between the chemosynthetically-based communities at vents, and the surrounding deep-sea communities reliant on photosynthetically-produced material exported from the surface waters. In terrestrial environments, boundaries of spatially heterogeneous habitats can have specific properties different from habitats that abut the boundary (Strayer et al. 2003), with boundaries (also known as 'edges', 'seres' or 'ecotones' in terrestrial ecology) often exhibiting higher species diversity than surrounding areas (Cox 1993). In terrestrial environments, these boundaries are some of the most productive habitat (Dodds 2009) and are considered generally beneficial to wildlife (Yahner 1988) with some species specifically adapted to boundary habitats (Cox 1993). The potential significance of inactive sulfide habitat, in terms of community diversity and endemic species, presents an important consideration for deep-sea mining, especially in cases where inactive deposits may be preferentially targeted.

\section{Patchiness and habitat fragmentation}

The different communities found at SMS deposits, with their adaptation to different deposit habitats, are likely to respond differently to fragmentation. Habitat fragmentation is the reduction in habitat and/or sizes of populations of species dependent on that habitat (Andren 1994, Fahrig 1997, 2003). Division of any remaining habitat into patches means each patch will experience at least partial isolation from other fragments (Fahrig 2003). Increased habitat fragmentation will negatively influence connectivity between habitats; this increases the risk of localised extinctions associated with demographic stochasticity, which are expected to be more common in small fragments than in more continuous tracts (Griffen and Drake 2008).

By removing all large organisms in the immediate area to be mined and altering the remaining habitat (Van Dover 2011, 2014), SMS mining would be expected to increase 
habitat fragmentation for communities colonising deposits. Although vent communities are naturally spatially fragmented and have adapted to a spatially and temporally variable environment with frequent disturbance, mining activity as an added cause of habitat fragmentation could still prove detrimental (Van Dover 2011). The fauna colonising inactive areas and other hard substrata are not endemic to these areas, and so are potentially not as vulnerable to habitat fragmentation; however, these fauna tend to have slower growth rates than vent specialists and are expected to take longer to recover (Van Dover 2011). Similar fauna at seamounts that were subjected to trawling showed no signs of recovery over a 5 to $10 \mathrm{yr}$ period following disturbance (Williams et al. 2010). Without knowing how connected communities at inactive areas and other hard substrata are to others in the region, it is difficult to predict the effect habitat fragmentation may have on their persistence within the metacommunity.

\section{Conservation biology and spatial planning}

Before developing strategies to mitigate the effects of anthropogenic disturbance, environmental managers must first decide which aspects of biodiversity they are aiming to conserve. In the broadest sense, biodiversity is "the variability among living organisms from all sources including, inter alia, terrestrial, marine and other aquatic ecosystems and the ecological complexes of which they are part; this includes diversity within species, between species and of ecosystems" (Glowka et al. 1994, p16). In the case of SMS mining, this would mean developing strategies that conserve all components of the community, from bacteria to megafauna, and not just at a species level, but to include the genetic diversity amongst populations. This is a daunting prospect, especially when there are so many unknowns regarding SMS deposit ecology.

Conservation methods strive for efficiency, with the aim of protecting the largest number of conservation targets in the fewest sites or at the lowest cost (Possingham and Wilson 2005). Taking into consideration that SMS mining is expected to remove all large organisms and their associated habitat in the immediate area to be mined (Van Dover 2011), there appears little scope for mitigation at the actual mine site. The main management strategy currently proposed is the designation of protected areas (also known as 'set-aside' sites, 'reference' sites or 'preservation reference zones') to preserve all aspects of biodiversity that could otherwise be lost from the region through mining. These areas should have similar physical and biological characteristics to the mine site and should be located so as not to be impacted by mining activities (Coffey Natural Systems 2008, Collins et al. 2013). 
Only one SMS mining project has so far implemented the set-aside strategy, and has opted for a single protected area with similar biological characteristics to the mine site (Collins et al. 2012). In shallow marine systems, there is a general move towards multiple protected areas as part of a network (IUCN 2008); even within the deep sea, networks of chemosynthetic ecosystem reserves (CERs) have been proposed as a way to protect the diversity, structure, function and resilience of vent ecosystems in the likelihood of mineral extraction (International Seabed Authority 2011, Van Dover et al. 2012). This leads to questions regarding protected area design; how large do sites need to be, and in the case of network design; how many sites are required for the network to be effective?

In the terrestrial environment, these questions resulted in the 'SLOSS' (Single Large or Several Small) debate: namely, are two small reserves more effective than one large reserve in conserving the maximum number of species (Gilpin and Diamond 1980, Higgs and Usher 1980, Diamond 1975b, 1976, Simberloff and Abele 1976)? The answer is not straight forward and depends upon the spatial heterogeneity of habitats in the region and characteristics of the communities colonising them. If communities are distributed uniformly throughout a region, a single large preserve contains more species than several small reserves; however, when a region contains major habitat gradients or centres of diversity, a single preserve would not hold as many species as several smaller reserves located in different areas of the region (Simberloff and Abele 1976, 1982).

Protecting a network of smaller sites also has the advantage of spreading protection across multiple populations of a species, rather than concentrating it in a single reserve (Cox 1993); for communities at risk from catastrophic conditions, a subdivision of reserves provides the best guarantee that species will survive somewhere within the set of preserves (Quinn and Hastings 1987; although see Gilpin 1988, Quinn and Hastings 1988). As SMS habitat and communities are patchily distributed and at risk from extensive natural disturbances (such as paving with lava during volcanic eruption; Lutz et al. 1994, Tunnicliffe et al. 1997, Shank et al. 1998), a network of multiple smaller reserves would be more prudent than a single large reserve; unless that reserve were of sufficient size to encompass an entire region containing a network of SMS communities.

It is widely accepted within ecology that habitat is unlikely to persist indefinitely in any one location, and that changes within the landscape result in patches of habitat that locally fluctuate amongst successional changes. This is of particular concern for hydrothermal vent habitat; whilst the hydrothermal activity of a vent field can persist for thousands of years (Jamieson et al. 2013), individual SMS deposits, and chimney complexes and vents within a deposit, can switch on and off over just a few years (Sen et 
al. 2014, Sarrazin et al. 1997). One way to accommodate this would be encompass whole deposits within the network, so that temporal and spatial fluctuations in hydrothermal activity and associated shifts in community dynamics can be represented.

Another way to address shifts in habitat type within a protected area over time would be to adopt a less static approach, such as active adaptive management (Walters and Holling 1990). This approach enables systematic evaluation of management strategy outcomes and if they are not working, to refine management strategies and evaluate the success of the changes. This allows managers to select the best performing management options but whether it could be practically applied in an SMS mining context remains to be seen. Such an approach would require detailed and continued monitoring; communities colonising inactive and non-hydrothermal vent substrata, being similar to those at seamounts, are expected to take decades to recover (Van Dover 2011, Williams et al. 2010). As a consequence, adopting an adaptive management approach would be a substantial commitment.

Terrestrial studies have demonstrated that landscape persistence and maximum population size depends not only on the number and size of habitat patches available but the ability of individuals to move between patches (Kareiva and Wennergren 1995); protected areas need to be connected to be effective. In terrestrial environments, connection between protected areas can be provided by habitat corridors (Macclintock et al. 1977, Rosenberg et al. 1997); this is not an option for SMS communities, whose inhabitants are predominantly sessile or with limited adult movement and whose habitat is naturally spatially fragmented. Instead, connectivity between sites is maintained by larval dispersal (Hilário et al. 2015, Boschen et al. 2016a). Maintaining connectivity amongst sites is necessary to facilitate genetic exchange and for the maintenance of healthy populations (International Seabed Authority 2011, Van Dover et al. 2012, Boschen et al. 2016a). However, determining connectivity within a network of protected areas requires detailed information on larval dispersal and development, local current regimes and the genetic structure of populations; much of which remains unknown in the deep sea (Hilário et al. 2015).

\section{Developing studies to contribute to the environmental management of SMS deposits within the New Zealand EEZ}

SMS deposits rich in silver and gold occur within the New Zealand Exclusive Economic Zone (EEZ) along the Kermadec Volcanic Arc (de Ronde et al. 2011). These deposits 
occur at exploitable depths (Wright 1994, Wright et al. 1998, Wright and Gamble 1999), with prospecting licences to investigate these resources issued to Neptune Minerals Inc. in 2002 (https://permits.nzpam.govt.nz/aca/). Despite hydrothermal communities first being recorded from the Arc in 2000, there has been very little published on the distribution and structure of these communities (Clark and O'Shea 2001, Rowden et al. 2003) and no research on the communities inhabiting the inactive and non-hydrothermal hard substrata in close proximity to active vents. If suitable management strategies are to be devised to mitigate the effects of SMS mining along the Arc, there needs to be detailed information on the communities that could be at risk from mining activities. Such information is an essential input for determining the spacing and location of protected areas along the Arc, if they are to form a coherent network.

The studies outlined in this thesis were designed jointly to provide some of the information needed to design such a network. The Introduction outlines the ecological and conservation theory pertinent to SMS deposit communities, providing the scientific rationale for the research that follows (Chapter 1 ). Very few studies have been conducted on the ecology of licenced SMS deposits; to place the New Zealand deposits in perspective, a global literature review was conducted on all aspects of SMS deposit environment and ecology (Chapter 2: Boschen et al. 2013). To address the complexity of heterogeneity at seamount-hosted SMS deposits, the influence of hydrothermal activity on assemblage structure at sites licenced for prospecting within New Zealand was investigated at two spatial scales. The first study assessed the assemblage structure of the megabenthos both within and amongst three seamounts with different levels of hydrothermal activity (Chapter 3: Boschen et al. 2015b). The second study compared a proposed mine site and reference site within one of the study seamounts to determine the suitability of the proposed reference site as a potential protected area (Chapter 4: Boschen et al. 2016b). These two studies also sought to determine if there was a unique assemblage colonising inactive sulfide areas. The final study began to assess the connectivity amongst areas licenced for prospecting along the Arc through determining the population genetic connectivity of a New Zealand-endemic hydrothermal vent species (Chapter 5: Boschen et al. 2015a). The findings from these studies were brought together in a final Synopsis (Chapter 6) to discuss how a protected area network could be formed along the Kermadec Volcanic Arc, and to provide recommendations for developing the emerging field of SMS deposit ecology. 


\section{References}

Allaby M (1998) Oxford dictionary of ecology, 2nd ed. Oxford University Press, New York, NY.

Andren H (1994) Effects of habitat fragmentation on birds and mammals in landscapes with different proportions of suitable habitat: A review. Oikos 71, 355-366.

Appeltans W, Ahyong ST, Anderson G, Angel MV, Artois T, Bailly N, Bamber R, Barber A, Bartsch I, Berta A, Blazewicz-Paszkowycz M, Bock P, Boxshall G, Boyko CB, Brandão SN, Bray RA, Bruce NL, Cairns SD, Chan T-Y, Cheng L, Collins AG, Cribb T, CuriniGalletti M, Dahdouh-Guebas F, Davie PJF, Dawson MN, de Clerck O, Decock W, de Grave S, de Voogd NJ, Domning DP, Emig, CC, Erséus C, Eschmeyer W, Fauchald K, Fautin DG, Feist SW, Fransen CHJM, Furuya H, Garcia-Alvarez O, Gerken S, Gibson D, Gittenberger A, Gofas S, Gómed-Daglio L, Gordon DP, Guiry MD, Hernandez F, Hoeksema BW, Hopcroft RR, Jaume D, Kirk P, Koedam N, Koenemann S, Kolb JB, Kristensen RM, Kroh A, Lambert G, Lazarus DB, Lemaitre R, Longshaw M, Lowry J, Macpherson E, Madin LP, Mah C, Mapstone G, McLaughlin PA, Mees J, Meland K, Messing CG, Mills CE, Molodtsova TN, Mooi R, Neuhaus B, Ng PKL, Nielsen C, Norenburg J, Opresko DM, Osawa M, Paulay G, Perrin W, Pilger JF, Poore GCB, Pugh P, Read GB, Reimer JD, Rius M, Rocha RM, Saiz-Salina JI, Scarabine V, Schierwater B, Schmidt-Rhaesa A, Schnabel KE, Schotte M, Schuchert P, Schwabe E, Segers H, Self-Sullivan C, Shenkar N, Siegel V, Sterrer W, Stöhr S, Swalla B, Tasker ML, Thuesen EV, Timm T, Todaro MA, Turon X, Tyler S, Uetz P, van der Land J, Vanhoorne B, van Ofwegen LP, van Soest RWM, Vanaverbeke J, Walker-Smith G, Walter TC, Warren A, Williams GC, Wilson SP, Costello MJ (2012) The Magnitude of Global Marine Species Diversity. Current Biology 22, 2189-2202.

Arquit AM (1990) Geological and hydrothermal controls on the distribution of megafauna in

Ashes Vent Field, Juan de Fuca Ridge. Journal of Geophysical Research-Solid Earth and Planets 95, 12947-12960.

Baker E, Beaudoin Y (eds.) (2013) Deep sea minerals: sea floor massive sulphides, a physical, biological, environmental, and technical review, Vol 1A. Secretariat of the Pacific Community, 52 pp.

Belyea LR, Lancaster J (1999) Assembly rules within a cotingent ecology. Oikos 86, 401416.

Boschen RE, Collins PC, Tunnicliffe V, Carlsson J, Gardner JPA, Loew J, McCrone A, Metaxas A, Sinniger F, Swaddling A (2016a) A primer for use of genetic tools in 
selecting and testing the suitability of set-aside sites protected from deep-sea seafloor massive sulfide mining activities. Ocean \& Coastal Management 122, 37-48.

Boschen RE, Rowden AA, Clark MR, Gardner JPA (2015a) Limitations in the use of archived vent mussel samples to assess genetic connectivity among seafloor massive sulfide deposits: a case study with implications for environmental management. Frontiers in Marine Science 2, 1-14.

Boschen RE, Rowden AA, Clark MR, Barton SJ, Pallentin A, Gardner JPA (2015b) Megabenthic assemblage structure on three New Zealand seamounts: implications for seafloor massive sulfide mining. Marine Ecology Progress Series 523, 1-14.

Boschen RE, Rowden AA, Clark MR, Gardner JPA (2013) Mining of deep-sea seafloor massive sulfides: A review of the deposits, their benthic communities, impacts from mining, regulatory frameworks and management strategies. Ocean \& Coastal Management 84, 54-67.

Boschen RE, Rowden AA, Clark MR, Pallentin A, Gardner JPA (2016b) Seafloor massive sulfide deposits support unique megafaunal assemblages: implications for seabed mining and conservation. Marine Environmental Research 115, 78-88.

Chase JM (2003) Community assembly: when should history matter? Oecologia 136, 489498.

Clark MR, O'Shea S (2001) Hydrothermal vent and seamount fauna from the southern Kermadec Ridge, New Zealand. InterRidge News 10, 14-17.

Clements FE (1936) Nature and structure of the climax. Journal of Ecology 24, 252-284.

Coffey Natural Systems (2008) Environmental Impact Statement, Solwara 1 project, Nautilus Minerals Niugini limited, Main Report, Vol A. Coffey Natural Systems, Brisbane, Australia, $222 \mathrm{pp}$.

Collins PC, Kennedy R, Copley JT, Boschen RE, Forde J, Se-Jong J, Lindsay D, Marsh L, Nye V, Patterson A, Watanabe H, Yamamoto H, Carlsson J, Thaler AD (2013b) VentBase: developing a consensus among stakeholders in the deep-sea regarding Environmental Impact Assessment for deep-sea mining - a workshop report. Marine Policy 42, 334-336.

Collins PC, Kennedy R, Van Dover CL (2012) A biological survey method applied to seafloor massive sulphides (SMS) with contagiously distributed hydrothermal-vent fauna. Marine Ecology Progress Series 452, 89-107.

Corliss JB, Dymond J, Gordon LI, Edmond JM, von Herzen RP, Ballard RD, Green K, Williams D, Bainbridge A, Crane K, van Andel TH (1979) Submarine thermal springs on the Galápagos Rift. Science 203, 1073-1083. 
Costello MJ, Ballantine B (2015) Biodiversity conservation should focus on no-take Marine Reserves: $94 \%$ of Marine Protected Areas allow fishing. Trends in Ecology \& Evolution 30, 9, 507-509.

Cox GW (1993) The design of natural preserves. Conservation Ecology. Wm. C. Brown Communications, Inc., Dubuque, IA, pp 300-309.

Cuvelier D, Sarrazin J, Colaço A, Copley J, Desbruyères D, Glover AG, Tyler P, Santos RS (2009) Distribution and spatial variation of hydrothermal faunal assemblages at Lucky Strike (Mid-Atlantic Ridge) revealed by high-resolution video image analysis. Deep-Sea Research Part I-Oceanographic Research Papers 56, 2026-2040.

de Ronde CEJ, Massoth GJ, Butterfield DA, Christenson BW, Ishibashi J, Ditchburn RG, Hannington MD, Brathwaite RL, Lupton JE, Kamenetsky VS, Graham IJ, Zellmer, GF, Dziak RP, Embley RW, Dekov VM, Munnik F, Lahr J, Evans LJ, Takai K (2011) Submarine hydrothermal activity and gold-rich mineralization at Brothers Volcano, Kermadec Arc, New Zealand. Mineralium Deposita 46, 541-584.

Diamond JM (1975a) Assembly of Species Communities. In: Cody ML, Diamond JM (eds.) Ecology and evolution of communities. Harvard University Press, Cambridge, MA, pp 342-445.

Diamond JM (1975b) The island dilemma: lessons of modern biogeographic studies for the design of natural reserves. Biological Conservation 7, 129-146.

Diamond JM (1976) Island biogeography and conservation: strategy and limitations. Science 193, 1027-1029.

Dodds WK (2009) Theories. Laws, theories, and patterns in ecology. University of California Press Ltd., Berkeley and Los Angeles, pp 67-143.

Drake JA (1991) Community-assembly mechanics and the structure of an experimental species ensemble. The American Naturalist 137, 1-26.

Erickson KL, Macko SA, Van Dover CL (2009) Evidence for a chemoautotrophically based food web at inactive hydrothermal vents (Manus Basin). Deep-Sea Research Part IITopical Studies in Oceanography 56, 1577-1585.

Fahrig L (1997) Relative effects of habitat loss and fragmentation on population extinction. The Journal of Wildlife Management 61, 603-610.

Fahrig L (2003) Effects of habitat fragmentation on biodiversity. Annual Review of Ecology, Evolution, and Systematics 34, 487-515.

Fukami T, Bezemer TM, Mortimer SR, van der Putten WH (2005). Species divergence and trait convergence in experimental plant community assembly. Ecology Letters 8, 12831290. 
Galkin SV (1997) Megafauna associated with hydrothermal vents in the Manus Back-Arc Basin (Bismarck Sea). Marine Geology 142, 197-206.

Gaston KJ, Jackson SF, Cantú-Salazar L, Cruz-Piñón G (2008) The ecological performance of protected areas. Annual Review of Ecology, Evolution, and Systematics 39, 93-113.

Gilpin ME, Diamond JM (1980) Subdivision of nature reserves and the maintenance of species diversity. Nature, 285, 567-568.

Gilpin ME (1988) A comment on Quinn and Hastings: extinction in subdivided habitats. Conservation Biology 2, 290-292.

Gleason HA (1926) The individualistic concept of the plant association. Bulletin of the Torrey Botanical Club 53, 7-26.

Glover AG, Higgs N, Horton T (2016) World register of deep-sea species [Online]. Available: http://www.marinespecies.org/deepsea (accessed May 16th 2016).

Glowka L, Burhenne-Guilmin F, Synge H, McNeely JA, Gündling L (1994) A guide to the convention on biological diversity. Environmental Policy and Law 30. IUCN - The World Conservation Union, Gland Switzerland and Cambridge UK, 161 pp.

Grassle JF (1985) Hydrothermal vent animals: distribution and biology. Science 229, 713717.

Gravel D, Canham CD, Beaudet M, Messier C (2006) Reconciling niche and neutrality: the continuum hypothesis. Ecology Letters 9, 399-409.

Griffen BD, Drake JM (2008) Effects of habitat quality and size on extinction in experimental populations. Proceedings of the Royal Society of London B: Biological Sciences 275, 2251-2256.

Halford A, Cheal AJ, Ryan D, Williams DM (2004) Resilience to large-scale disturbance in coral and fish assemblages on the Great Barrier Reef. Ecology 85, 1892-1905.

Hanski I, Gilpin M (1991) Metapopulation dynamics: brief history and conceptual domain. Biological Journal of the Linnean Society 42, 3-16.

Higgs AJ, Usher MB (1980) Should nature reserves be large or small? Nature 285, 5766, 568-569.

Hilário A, Metaxas A, Gaudron S, Howell K, Mercier A, Mestre N, Ross RE, Thurnherr A, Young $C$ (2015) Estimating dispersal distance in the deep sea: challenges and applications to marine reserves. Frontiers in Marine Science, 2, 1-14.

Holyoak M, Leibold MA, Mouquet NM, Holt RD, Hoopes MF (2005) Metacommunities: a framework for large-scale community ecology. In: Holyoak M, Leibld MA, Holt RD 
(eds.) Metacommunities: spatial dynamics and ecological communities. University of Chicago Press, Chicago, IL, pp 1-31.

International Seabed Authority (2011) Environmental management of deep-sea chemosynthetic ecosystems: justification of and considerations for a spatially-based approach. ISA Technical Study Series, 9. International Seabed Authority, Kingston, Jamaica, $79 \mathrm{pp}$.

IUCN (1994). Guidelines for protected areas management categories. IUCN Commission on National Parks and Protected Areas and the World Conservation Monitoring Centre, Cambridge UK and Gland Switzerland, 83 pp.

IUCN (2008) Establishing resilient marine protected area networks - making it happen. IUCN World Commission on Protected Areas (IUCN-WCPA), National Oceanic and Atmospheric Administration and The Nature Conservancy, Washington, DC, 118 pp. Jamieson JW, Hannignton MD, Clague DA, Kelley DS, Delaney JR, Holden JF, Tivey MK, Kimpe LE (2013) Sulfide geochronology along the Endeavour Segment of the Juan de Fuca Ridge. Geochemistry, Geophysics, Geosystems 14, 2084-2099.

Jax K (2006) Ecological units: definitions and application. The quarterly review of biology 81, 237-58.

Joppa LN, Pfaff A (2009) High and far: biases in the location of protected areas. Plos One 4, e8273.

Kareiva P, Wennergren U (1995) Connecting landscape patterns to ecosystem and population processes. Nature 373, 299-302.

Kinlan BP, Gaines SD (2003) Propagule dispersal in marine and terrestrial environments: a community perspective. Ecology 84, 2007-2020.

Leibold MA, Holyoak M, Mouquet NM, Amaraskare P, Chase JM, Hoopes MF, Holt RD, Shurin JB, Law R, Tilman D, Loreau M, Gonzalez A (2004) The metacommunity concept: a framework for multi-scale community ecology. Ecology Letters 7, 601-613.

Levins R (1969) Some demographic and genetic consequences of environmental heterogeneity for biological control. Bulletin of the Entomological Society of America $15,237-240$.

Levins R (1970) Extinction. In: Gesternhaber M (ed.) Some mathemetical problems in biology. American Mathematical Society, Providence, RI, pp 77-107.

Lutz RA, Shank TM, Fornari DJ, Haymon RM, Lilley MD, Vondamm KL, Desbruyères D (1994) Rapid growth at deep-sea vents. Nature 371, 663-664.

MacArthur R, Wilson E (1967). The Theory of Island Biogeography, Princeton University Press, Princeton, NJ, 203 pp. 
Macclintock L, Whitcomb RF, Whitcomb BL (1977) Evidence for the value of corridors and minimization of isolation in preservation of biotic diversity. American Birds 31, 6-16.

Marsh L, Copley JT, Huvenne VAI, Linse K, Reid WDK, Rogers AD, Sweeting CJ, Tyler PA (2012) Microdistribution of faunal assemblages at deep-sea hydrothermal vents in the Southern Ocean. Plos One 7, e48348.

Metaxas A (2011) Spatial patterns of larval abundance at hydrothermal vents on seamounts: evidence for recruitment limitation. Marine Ecology Progress Series 437, 103-117.

Mullineaux LS, Adams DK, Mills SW, Beaulieu SE (2010). Larvae from afar colonize deepsea hydrothermal vents after a catastrophic eruption. Proceedings of the National Academy of Sciences of the United States of America 107, 7829-7834.

Nautilus Minerals Inc. (2016) The pipeline: PNG [Online]. Available: http://www.nautilusminerals.com/irm/content/png.aspx?RID=258 (accessed May 16th 2016).

Pianka ER (1970) On r- and K-Selection. The American Naturalist 104, 592-597.

Pimm SL, Jenkins CN, Abell R, Brooks TM, Gittleman JL, Joppa LN, Raven PH, Roberts CM, Sexton OJ (2014) The biodiversity of species and their rates of extinction, distribution, and protection. Science 344, 6187, 12467521.

Podowski EL, Ma S, Luther GW, Wardrop D, Fisher CR (2010) Biotic and abiotic factors affecting distributions of megafauna in diffuse flow on andesite and basalt along the Eastern Lau Spreading Center, Tonga. Marine Ecology Progress Series 418, 25-45.

Podowski EL, Moore TS, Zelnio KA, Luther GW, Fisher CR (2009) Distribution of diffuse flow megafauna in two sites on the Eastern Lau Spreading Center, Tonga. Deep Sea Research Part I: Oceanographic Research Papers 56, 2041-2056.

Possignham HP, Wilson KA (2005) Biodiversity: Turning up the heat on hotspots. Nature 436, 919-920.

Pulliam HR (1988) Sources, sinks and population regulation. American Naturalist 132, 652-661.

Quinn JF, Hastings A (1987) Extinction in subdivided habitats. Conservation Biology 1, 198-209.

Quinn JF, Hastings A (1988) Extinction in subdivided habitats: reply to Gilpin. Conservation Biology 2, 293-296.

Ramirez-Llodra E, Tyler PA, Baker MC, Bergstad OA, Clark MR, Escobar E, Levin, LA, Menot L, Rowden AA, Smith CR, Van Dover CL (2011) Man and the last great wilderness: human impact on the deep sea. Plos One 6, 8, e22588. 
Rosenberg DK, Noon BR, Meslow EC (1997) Biological corridors: form, function and efficacy. BioScience 47, 677-687.

Rowden AA, Clark MR, O'Shea S, Mcknight DG (2003) Benthic biodiversity of seamounts on the southern Kermadec Volcanic Arc. Marine Biodiversity Biosecurity Report 3, National Institute of Water and Atmospheric Research, Wellington, New Zealand, 23 pp.

Samuels CL, Drake JA (1997) Divergent perspectives on community convergence. Trends in Ecology and Evolution 12, 427-432.

Sarrazin J, Juniper SK, Massoth G, Legendre P (1999) Physical and chemical factors influencing species distributions on hydrothermal sulfide edifices of the Juan de Fuca Ridge, northeast Pacific. Marine Ecology Progress Series 190, 89-112.

Sarrazin J, Robigou V, Juniper SK, Delaney JR (1997) Biological and geological dynamics over four years on a high-temperature sulfide structure at the Juan de Fuca Ridge hydrothermal observatory. Marine Ecology Progress Series 153, 5-24.

Schoner TW (1974) Resource partitioning in ecological communities. Science 185, 27-39.

Sen A, Becker EL, Podowski EL, Wickes LN, Ma S, Mullaugh KM, Hourdez S, Luther GW III, Fisher CR (2013) Distribution of mega fauna on sulfide edifices on the Eastern Lau Spreading Center and Valu Fa Ridge. Deep-Sea Research Part I-Oceanographic Research Papers 72, 48-60.

Sen A, Podowski E, Becker E, Shearer E, Gartman A, Yücel M, Hourdez S, Luther GW III, Fisher $C$ (2014) Community succession in hydrothermal vent habitats of the Eastern Lau Spreading Center and Valu Fa Ridge, Tonga. Limnology and Oceanography 59, 1510-1528.

Shank TM, Fornari DJ, Von Damm KL, Lilley MD, Haymon RM, Lutz RA (1998) Temporal and spatial patterns of biological community development at nascent deep-sea hydrothermal vents (9 degrees 50 ' N, East Pacific Rise). Deep-Sea Research Part IITopical Studies in Oceanography 45, 465-515.

Siitonen P, Lehtinen A, Siitonen M (2005) Effects of forest edges on the disturbance, abundance and regional persistence of wood-rotting fungi. Conservation Biology 19, 250-260.

Simberloff DS, Abele LG (1982) Refuge design and island biogeographic theory: effects of fragmentation. The American Naturalist 120, 41-50.

Simberloff DS, Abelle LG (1976) Island biogeography theory and conservation practice. Science 191, 285-286. 
Snall T, Ehrlen J, Rydin H (2005) Colonization-extinction dynamics of an epiphyte metapopulation in a dynamic landscape. Ecology 86, 106-115.

Strayer DL, Power ME, Fagan WF, Pickett STA, Belnap J (2003) A classification of ecological boundaries. BioScience 53, 723-729.

Sudarikov SM, Galkin SV (1995) Geochemistry of the Snake Pit vent field and its implications for vent and non-vent fauna. In: Parson LM, Walker CL, Dixon DR (eds.) Hydrothermal vents and processes, Vol 87. Geological Society of London, London, UK, pp 319-327.

Tunnicliffe V, Embley RW, Holden JF, Butterfield DA, Massoth GJ, Juniper SK (1997) Biological colonization of new hydrothermal vents following an eruption on Juan de Fuca Ridge. Deep-Sea Research Part I-Oceanographic Research Papers 44, 16271644.

United Nations Environment Programme (2011) Strategic plan for biodiversity 2011-2020: Further information related to the technical rational for the Aichi Biodiversity Targets, including potential indicators and milestones. Conference of the parties to the convention on biological diversity, 14 March 2011 Nagoya, Japan. UNEP/CBD/COP/10/INF/12/Rev.1, $31 \mathrm{pp}$.

Van Dover CL (2000) The ecology of deep-sea hydrothermal vents. Princeton University Press, Princeton, NJ, 424 pp.

Van Dover CL (2011) Mining seafloor massive sulphides and biodiversity: what is at risk? ICES Journal of Marine Science 68, 341-348.

Van Dover CL (2014) Impacts of anthropogenic disturbances at deep-sea hydrothermal vent ecosystems: a review. Marine Environmental Research 102, 59-72.

Van Dover CL, Hessler RR (1990) Spatial variation in faunal composition of hydrothermal vent communities on the East Pacific Rise and Galapagos Spreading Center. In: McMurray GR (ed.) Gorda Ridge: a seafloor spreading center in the United States' Exclusive Economic Zone. Springer New York, New York, NY, pp 253-264.

Van Dover CL, Smith CR, Ardron J, Dunn D, Gjerde K, Levin L, Smith S (2012) Designating networks of chemosynthetic ecosystem reserves in the deep sea. Marine Policy 36, 378-381.

Vrijenhoek RC (1997) Gene flow and genetic diversity in naturally fragmented metapopulations of deep-sea hydrothermal vent animals. Journal of Heredity 88, 285293.

Vrijenhoek RC (2010) Genetic diversity and connectivity of deep-sea hydrothermal vent metapopulations. Molecular Ecology 19, 4391-4411. 
Walker LR, del Moral R (2003) Denudation: the creation of a barren substrate. Primary succession and ecosystem rehabilitation. Cambridge University Press, Cambridge, UK, pp 14-51.

Walters CJ, Holling CS (1990) Large-scale management experiments and learning by doing. Ecology 71, 2060-2068.

Warren PH, Law R, Weatherby AJ (2003) Mapping the assembly of protist communities in microcosms. Ecology 84, 1001-1011.

Watson JEM, Dudley N, Segan DB, Hockings M (2014) The performance and potential of protected areas. Nature 515, 67-73.

Whittaker RH (1951) A criticism of the plant association and climax concepts. Northwest Science 25, 17-31.

Whittaker RH (1956) Vegatation of the great Smoky Mountains. Ecological Monographs 26, 1-20.

Whittaker RH (1970) Introduction. Communites and Ecosystems. The Macmillan Company, Toronto, ON, pp 1-5.

Williams A, Schlacher TA, Rowden AA, Althaus F, Clark MR, Bowden DA, Stewart R, Bax NJ, Consalvey M, Kloser RJ (2010) Seamount megabenthic assemblages fail to recover from trawling impacts. Marine Ecology 31, 183-199.

Wilson EO (1992) The diversity of life. Belknap Press, Cambridge, MA, 440 pp.

With KA (2004) Metapopulation dynamics: perspectives from landscape ecology. In: Hanski I, Gaggiotti OE (eds.) Ecology, genetics and evolution of metapopulations. Academic Press, San Diego, CA, pp 23-44.

Wright IC (1994) Nature and tectonic setting of the southern Kermadec submarine arc volcanoes: an overview. Marine Geology 118, 217-236.

Wright IC, de Ronde CEJ, Faure K, Gamble JA (1998) Discovery of hydrothermal sulfide mineralization from southern Kermadec Arc volcanoes (SW Pacific). Earth and Planetary Science Letters 164, 335-343.

Wright IC, Gamble JA (1999) Southern Kermadec submarine caldera arc volcanoes (SW Pacific): caldera formation by effusive and pyroclastic eruption. Marine Geology 161, 207-227.

Wu J, Loucks OL (1995) From balance of nature to hierarchical patch dynamics: a paradigm shift in ecology. Quarterly Review of Biology 70, 439-466.

Yahner RH (1988) Changes in wildlife communities near edges. Conservation Biology 2, 333-339. 


\title{
CHAPTER 2. Mining of deep-sea seafloor massive sulfides: a review of the deposits, their benthic communities, impacts from mining, regulatory frameworks and management strategies.
}

\begin{abstract}
Seafloor massive sulfide (SMS) deposits form in a suite of hydrothermal settings across a range of depths. Many deposits are of a tonnage and mineral grade comparable to land deposits and are attractive to mining companies. Economically viable deposits can be either active or inactive, with different biological communities present at each. These benthic communities may include specially adapted and endemic fauna that could be severely impacted by mining activity. Although there is currently no active SMS mining, recent research from Industry and scientific investigations is able to inform decisions on the management of SMS deposits, including appropriate mitigation strategies to minimise the impact of mining activities. Mitigation strategies will likely focus on facilitating recolonization of areas impacted by mining, spatial management with open and closed areas and reducing the effects of sediment plumes from mining activity. Regulation of mining activity at SMS deposits can be complex, falling under national and international legislation alongside codes of practice issued by industry and other stakeholders. Despite decades of research effort, there are still many unknowns about the ecology of SMS deposits, in particular for inactive SMS sites and the genetic and demographic connectivity of populations amongst deposits. With considerable industry interest in the exploitation of SMS deposits in the Western South Pacific Ocean, there is an urgent need to assess the potential impact of SMS mining, particularly on the benthic fauna, so that appropriate management strategies can be designed and implemented.
\end{abstract}




\section{Introduction}

Seafloor Massive Sulfide (SMS) deposits are areas of hard substratum with high base metal and sulfide content that form through hydrothermal circulation and are commonly found at hydrothermal vent sites. The high base metal content, along with commercially exploitable concentrations of gold and silver, have interested mining companies for decades with some of the first exploration and feasibility studies in the marine environment occurring in the 1980s at $21^{\circ} \mathrm{N}$ on the East Pacific Rise (Crawford et al. 1984) and in the Red Sea (Amann 1985). Initial assessments of global marine mineral resources included SMS deposits (Emery and Skinner 1977) even before the hydrothermal vents that formed them were discovered in 1977 (Corliss et al. 1979). However, the cost of extraction, falling mineral prices and technological barriers appeared to halt potential SMS mining in the deep sea before it became a commercial reality (Van Dover 2011). Recent increases in mineral prices and mineral demand through the industrialisation of countries such as China and India, alongside technological advances has led to SMS mining becoming economically viable, with particular interest in SMS deposits in the Exclusive Economic Zones (EEZ) of Papua New Guinea (PNG) and New Zealand (NZ). In PNG, exploration licenses and mining leases were granted by the government in 1997 and 2011 respectively (http://www.nautilusminerals.com/). In NZ, the potential for deep-sea hydrothermal deposits was first assessed more than 20 years ago (Glasby and Wright, 1990) with large areas of seabed along the Kermadec and Colville Ridges being licensed for prospecting in 2002 (http://www.nzpam.govt.nz/cms/online-services/current-permits/).

Hydrothermally active sites are known to host unique communities of organisms dependent on the metal and sulfide-rich vent fluids that support the chemosynthetic bacteria at the base of the food web (reviewed in Van Dover 2000). Such communities are of considerable interest to science, in particular for biogeographic studies (e.g. Moalic et al. 2012) and understanding the origin of life on Earth (e.g. Corliss et al. 1981). These benthic communities are vulnerable to disturbance and localised loss; mining SMS deposits will remove all benthic organisms inhabiting the substratum, with any highturbidity, and potentially toxic sediment plumes resulting from mining activities likely to impact upon benthic communities downstream (Coffey Natural Systems 2008b). Recovery of communities at SMS deposits disturbed by mining activities will rely on re-colonisation from neighbouring populations, however, other than detailed studies at sites in PNG (Thaler et al. 2011, Collins et al. 2012), very little is known about the connectivity (genetic or demographic) of populations or the spatial distribution of benthic fauna at SMS deposits. 
Management strategies are required that can conserve the special biological communities and ecology of SMS deposits whilst enabling economically viable extraction of their valuable mineral resources (Van Dover 2011, International Seabed Authority 2011). Such resource management requires a robust legislative framework, clear management objectives, and comprehensive information on the SMS deposits themselves, their wider environment and the biological communities they support. Unfortunately, there are considerable gaps in our understanding of the ecology of SMS deposits that prevent the refining of existing legislation to better manage activities at SMS deposits (International Seabed Authority 2011). This review aims to summarise the current knowledge on SMS deposits, their benthic biological communities, the probable impacts of mining, existing legislative frameworks and management strategies to regulate mining, with particular reference to the proposed mining of the Manus Basin in the PNG EEZ, and the Kermadec volcanic arc system in the NZ EEZ. In particular, this review is designed to provide the necessary background information for those involved in managing SMS resources.

\section{The geology of seafloor massive sulfides}

\subsection{Formation and location of SMS deposits}

SMS deposits form through hydrothermal activity; cold seawater percolates down through the seafloor, is heated through geothermal energy, becomes buoyant and rises, dissolving metals and sulfides from the surrounding rocks. These hydrothermal systems can be low intensity (typically $<200^{\circ} \mathrm{C}$ ), which are generally thought unimportant in the formation of SMS deposits, or high-intensity (typically $200-400^{\circ} \mathrm{C}$ ), which although located at fewer more discreet sites, tend to concentrate mineral deposits (Rona 1985). The location of SMS deposit formation depends on circulation. In 'leaky' systems, mixing of primary hydrothermal fluids and seawater occurs beneath the seafloor so that SMS deposits occur within the oceanic crust, whereas in 'tight' systems hydrothermal fluids are expelled through vents where they mix with seawater to precipitate SMS deposits on the seafloor (Rona 1985). Rapid precipitation of metal sulfides from their host hydrothermal fluid in tight systems leads to chimney formation, with chimney collapse and coalescence forming sulfide mounds (Humphris et al. 1995).

SMS deposits can also form where hypersaline seawater in the subsurface hydrothermal convection system enhances the emission of metal-rich vent fluid. This fluid then becomes trapped by the density-stratified brines and precipitates out onto the basin floor, such as in the Red Sea (Bäcker and Schoell 1972, Amann 1985, Rona 1985, Alt et 
al. 1987). As well as SMS (also known as polymetallic sulfide deposits (PMS), henceforth referred to as SMS) typically associated with high-temperature vents, there are various other deposits associated with hydrothermal activity. These include low-temperature hydrothermal vents and associated mineral deposits (LTH), near-field metalliferous sediments (NFS), distal metalliferous sediments (DIS) and vein and breccia deposits (VSD). LTH are typically found at the margins of high-temperature vent fields and have low sulfide mineral accumulations; NFS consist of metal-rich particulates from hightemperature vent plume fallout; DIS are also formed from plume fallout but at greater distance from the plume source, and VSD occur where faulting and uplift exposes the mineralised stock work of a hydrothermal vent system (Hannington et al. 2002). Of these mineral deposits, SMS are the only deposits currently being investigated for commercial exploitation. SMS deposits can be either inactive or active, with continued hydrothermal activity required to build on existing deposits. However, the distinction between active and inactive deposits is not always clear, with rapid switching in activity of deposits complicating the definition of active and inactive areas (Coffey Natural Systems 2008b).

According to the InterRidge vent database, there are approximately 600 hydrothermal vents known globally from plume signals or direct observations (Beaulieu 2010), with many more vents expected to be discovered from unchartered waters (Baker and German 2004). Recent estimates suggest that at mid-ocean ridges alone, there are approximately 700 vent sites to discover (Baker and German 2004). Plume signal detection has been used to identify the location of many hydrothermal vent sites and their associated SMS deposits but this technique will underestimate SMS deposit distribution because inactive portions of the mid-ocean ridge system may host inactive deposits thousands of years old (Hannington et al. 2011). Recent estimates of global SMS deposits suggest deposits occur on average every $100 \mathrm{~km}$ along the oceanic plate boundaries with approximately 900 modern deposits globally (Hannington et al. 2011). From the approximately 600 hydrothermal vents discovered, there are only 95 confirmed SMS deposits on the publically available InterRidge Database (Beaulieu, 2010), although since the database was last updated, more deposits have been identified, increasing the current total to 165 (Hannington et al. 2011). These deposits have a broad spatial distribution (Fig. 1) and have been found across a range of depths (Table 1), with the shallower, more easily accessible (and so more economically viable) deposits likely to be mined first (Rona 2003). 


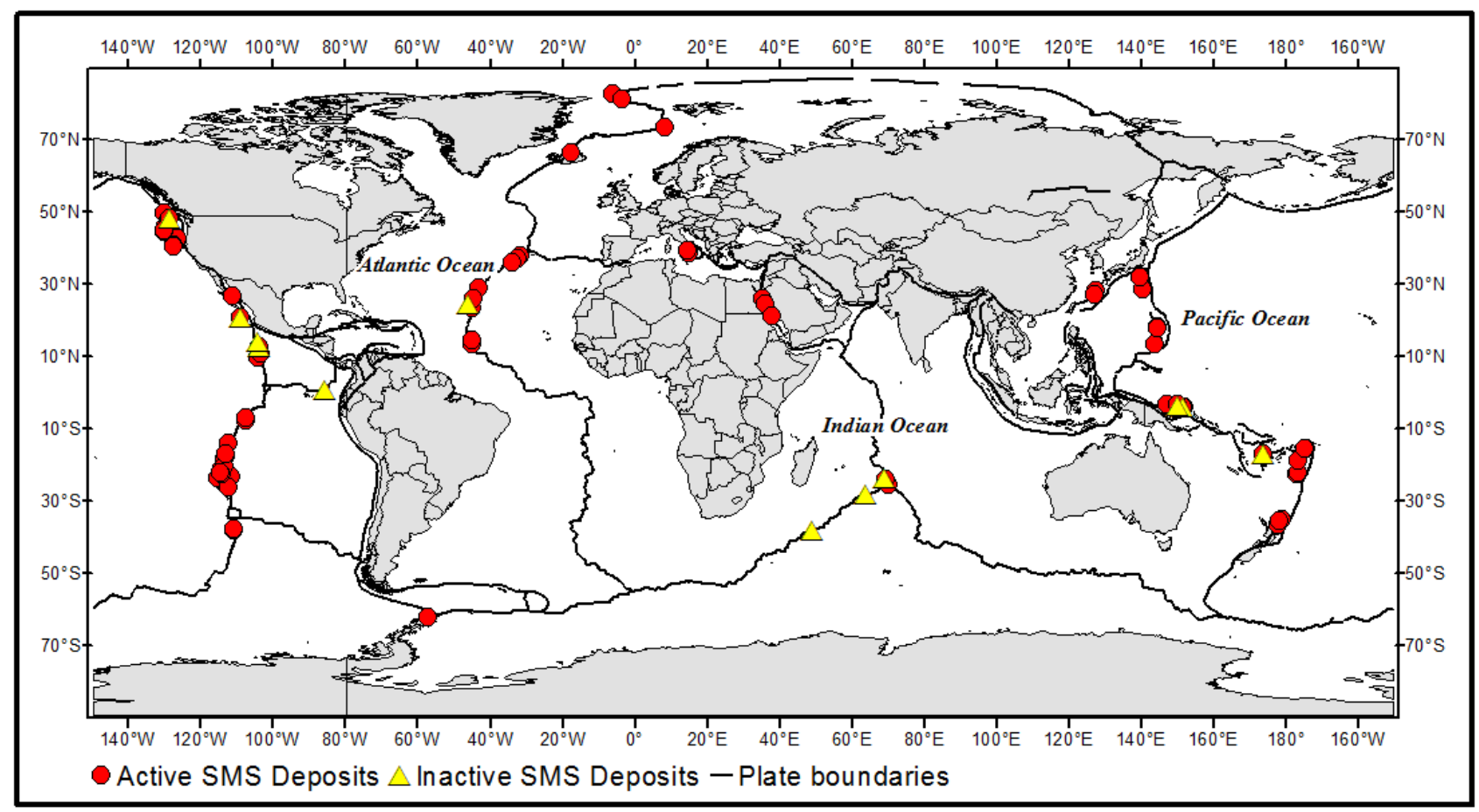

Figure 1. Global distribution of SMS deposits. Red circles: active deposits; yellow triangles: inactive deposits. Using data from the InterRidge Database (Beaulieu 2010). Note that more deposits are known (see Hannington et al. 2011) but their positions are not available to complete this figure.

SMS deposits have been found in many hydrothermal vent localities and in a variety of hydrothermal settings. These include along fast-spreading ridges, such as the East Pacific Rise (Francheteau et al. 1979, Spiess et al. 1980), slow spreading ridges, such as the Mid-Atlantic Ridge (Kong et al. 1985, Rona et al. 1986, Fouquet et al. 1994, Krasnov et al. 1995, Murton et al. 1995) and the Central Indian Ridge (Herzig and Plüger 1988, Plüger et al. 1990, Halbach et al. 1998) and ultraslow ridges, such as the Mid-Cayman Spreading Centre (Connelly et al. 2012).

Large SMS deposits associated with metal enriched sediments have been found in the Red Sea (Bäcker and Schoell 1972, Amann 1985, Rona 1985, Alt et al. 1987). SMS deposits have also been found in sediment-filled basins in the Gulf of California (Lonsdale et al. 1980), on sedimented ridges along the Juan de Fuca Ridge (Mottl et al. 1994, Zierenberg et al. 1996) and in association with felsic volcanism in the Eastern Manus Basin (Binns and Scott 1993). Known deposits are also located in back-arc spreading centres, such as the Central Manus Basin (Both et al. 1986), Mariana Trough (Craig et al. 1986, Kastner et al. 1986), Lau Basin (Fouquet et al. 1991), Okinawa Trough (Halbach et 
al. 1989), East Scotia Ridge (Rogers et al. 2012) and along arc systems, such as the Kermadec Arc (Wright et al. 1998, Stoffers et al. 1999, de Ronde et al. 2001).

Table 1. Summary of SMS deposit locations and depths using the InterRidge Database (Beaulieu 2010) Note that more deposits are known (see Hannington et al. 2011) but their positions and physical characteristics (active/inactive, depth) are not available to complete this table.

\begin{tabular}{|c|c|c|c|}
\hline Ocean & Region & Activity & $\begin{array}{l}\text { Maximum or Single Reported } \\
\text { Depth }(\mathrm{m}) \text { of individual deposits }\end{array}$ \\
\hline \multirow{4}{*}{ Indian } & Red Sea & Active & $1540-2200$ \\
\hline & \multirow[b]{2}{*}{ Central Indian Ridge } & Active & $2460-3320$ \\
\hline & & Inactive & 2850 \\
\hline & Southwest Indian Ridge & Inactive & $1500-2940$ \\
\hline Mediterranean & Aeolian Arc, Tyrrhenian Sea & Active & $200-1000$ \\
\hline Southern Ocean & Bransfield Strait & Active & 1080 \\
\hline \multirow[b]{12}{*}{ North Pacific } & Explorer Ridge & Active & 1850 \\
\hline & Gorda Ridge & Active & $2800-3300$ \\
\hline & Gulf of California & Active & 2000 \\
\hline & Izu-Bonin Arc & Active & $1110-1360$ \\
\hline & \multirow[b]{2}{*}{ Juan de Fuca Ridge } & Active & $1540-2450$ \\
\hline & & Inactive & 2400 \\
\hline & Galapagos Rift & Inactive & 2600 \\
\hline & Mariana Arc & Active & 1470 \\
\hline & Mariana Trough & Active & $3640-3676$ \\
\hline & \multirow[b]{2}{*}{ Northern East Pacific Rise } & Active & $2520-2650$ \\
\hline & & Inactive & $2000-2600$ \\
\hline & Okinawa Trough & Active & $740-1450$ \\
\hline \multirow[b]{8}{*}{ South Pacific } & Kermadec Arc & Active & $930-1800$ \\
\hline & Lau Basin & Active & $1764-2500$ \\
\hline & \multirow[b]{2}{*}{ Manus Basin } & Active & $1500-2500$ \\
\hline & & Inactive & $1920-2500$ \\
\hline & \multirow[b]{2}{*}{ North Fiji Basin } & Active & $1980-2000$ \\
\hline & & Inactive & 2000 \\
\hline & Pacific-Antarctic Ridge & Active & $2200-2240$ \\
\hline & Southern East Pacific Rise & Active & $2270-3000$ \\
\hline \multirow[b]{4}{*}{ Arctic } & Kolbeinsey Ridge & Active & 400 \\
\hline & Lena Trough & Active & 4000 \\
\hline & Mohns Ridge & Active & 2400 \\
\hline & Gakkel Ridge & Active & 4100 \\
\hline \multirow[b]{2}{*}{ North Atlantic } & \multirow[b]{2}{*}{ Northern Mid Atlantic Ridge } & Active & $865-3670$ \\
\hline & & Inactive & 3900 \\
\hline
\end{tabular}


Whether a deposit is from a fast-spreading or slow-spreading centre will influence the distribution and frequency of occurrence of SMS deposits (Rona 1985), affecting the mineral grade and economic viability of mining a deposit. The hydrothermal setting of deposits also affects their density, with active deposits at slow and fast spreading ridges occurring on average every $174 \mathrm{~km}$ and $54 \mathrm{~km}$ respectively (Hannington et al. 2011), whilst back-arc spreading centres host deposits at similar densities to slow spreading ridges (Hannington et al. 2011). There is also the potential for a large number of inactive unknown sites, so the spacing of inactive deposits is uncertain.

\subsection{Mineral composition and size of deposits}

Deposits are typically enriched with base metals (iron, zinc, copper and lead), sulfides and numerous other elements, including calcium, lead, gold, silver, arsenic, cobalt, molybdenum and platinum (Krasnov et al. 1995). The exact mineral composition of deposits varies according to hydrothermal activity, tectonic setting and the section of the deposit sampled. For example, although active deposits from the Mid-Atlantic Ridge (MAR), East Pacific Rise (EPR), Central Indian Ridge (CIR), Lau Basin and Okinawa Trough are broadly comparable in iron, zinc and copper concentrations (Halbach et al. 1989, Fouquet et al. 1991, Krasnov et al. 1995), deposits from back-arc basins tend to have lower iron and higher gold content than from Mid Ocean Ridge (MOR) systems (Von Damm 1990). There are subtle differences between active and inactive deposits, with active deposits at MOR systems having a higher calcium content and inactive deposits being enriched with silver and gold (Krasnov et al. 1995). The temperature of venting will influence mineral composition with high $\left(>300^{\circ} \mathrm{C}\right)$ and low $\left(<300^{\circ} \mathrm{C}\right)$ temperature venting associated with copper and zinc enrichment respectively (Hannington and Scott 1988), such as in deposits from the CIR (Halbach et al. 1998). The percentage metal composition may also vary within deposits, with concentrations of iron, copper and zinc all increasing with increasing penetration of deposits in the Okinawa Trough (Halbach et al. 1989). Precious metals also occur in high concentrations in SMS deposits, with the most gold-rich deposits also containing the highest silver, arsenic and lead concentrations, typically in low-temperature Zn-rich deposits (Hannington et al. 1986). The gold and silver composition of SMS deposits depends on numerous site-dependent factors, including temperature, $\mathrm{pH}$, total reduced sulfur concentrations, salinity and the oxidation state of the hydrothermal fluid (Hannington and Scott 1988).

Recent estimates suggest that global massive sulfide deposits in the modern volcanic zones of the global ocean amount to $6 \times 10^{8}$ tonnes, with an estimated copper 
and zinc mass of $3 \times 10^{7}$ tonnes, comparable to the discovered metal in modern massive sulfide deposits on land (Hannington et al. 2011). As well as having ore grades comparable to land deposits (Hannington et al. 2011), SMS deposits in the sea can occur on a scale comparable to them, although many land deposits are an order of magnitude greater in size (Hoagland et al. 2010). The size of SMS deposits can vary widely, such as at the TAG and Broken Spur sites along the MAR. The TAG site includes an SMS mound $250 \mathrm{~m}$ diameter and $50 \mathrm{~m}$ high, topped with hydrothermal vent chimneys (Rona et al. 1986), whilst the Broken Spur site hosts at least five sulfide mounds ranging in size from 5 $\mathrm{m}$ high and $3 \mathrm{~m}$ diameter to $40 \mathrm{~m}$ high with a $20 \mathrm{~m}$ base (Murton et al. 1995). Deposits at MAR are comparable in size to those at the Southern Explorer Ridge where ten of the largest sulfide mounds had a diameter of $150 \mathrm{~m}$ and depth of $5 \mathrm{~m}$, amounting to a total of 2.7 - 4.5 million tonnes of SMS deposit (Hannington and Scott 1988). Estimates of gold and silver deposits at Southern Explorer Ridge alone amount to $2.0-3.4$ tonnes of gold and 255 - 396 tonnes of silver (Hannington and Scott 1988).

The SMS deposits that will likely be amongst the first to be mined occur in the Manus Basin, north of PNG. Investigations have identified a mineralised ore body at a site called "Solwara 1" consisting of a mound $2 \mathrm{~km}$ in diameter rising $200 \mathrm{~m}$ above the seafloor. The ore consists of $870,000-1300000$ tonnes, containing $6.8-7.5 \%$ weight copper and $4.8-7.2 \mathrm{~g} \mathrm{t}^{-1}$ of gold (Coffey Natural Systems 2008b). Other deposits currently being explored for mining potential include those in the NZ EEZ along the Kermadec arcback arc system (Wright et al. 1998, Stoffers et al. 1999, de Ronde et al. 2001), where deposits exist at exploitable depths of $150-200 \mathrm{~m}$ in the Bay of Plenty (Stoffers et al. 1999), $870-930 \mathrm{~m}$ at Clark Seamount (Malahoff 2008) and as deep as $1150-1800 \mathrm{~m}$ at Brothers Seamount (Wright et al. 1998). Deposits at Brothers Seamount are also rich in base (Wright et al. 1998) and precious (de Ronde et al. 2011) metals with high concentrations of copper, zinc, iron and gold (up to $15.3 \%$ weight, $18.8 \%$ weight, $19.1 \%$ weight and $91 \mathrm{~g} \mathrm{t}^{-1}$ respectively).

\section{The benthic communities of seafloor massive sulfide deposits}

\subsection{Communities at SMS deposits}

Two main types of benthic communities are found at SMS deposits, a chemosynthetic community of hydrothermal vent specialists inhabiting active deposits; and a community of background fauna colonising inactive deposits (also known as periphery and halo fauna). A third community is also hypothesised to exist, comprising specialised fauna adapted to the unique chemical environment of weathering inactive deposits (Van Dover 2007, 2011). 
The community of hydrothermal vent specialists has been studied in great detail at numerous locations - see reviews by Lutz and Kennish (1993) and Van Dover (2000). This community is supported by chemosynthetic bacteria reliant on the methane or sulfide-rich vent fluids for primary production (Karl et al. 1980). Many vent specialists are in symbiosis with these chemosynthetic bacteria and can only survive in close proximity to vent fluid emissions. For example, the tubeworm Riftia pachyptila has no mouth or gut and obtains its energy from the endosymbiotic bacteria housed within a specialised sack-like organ, the trophosome (Cavanaugh et al. 1981, Felbeck 1981, Jones 1981). Hydrothermal vent fauna typically have high biomass and low diversity (Grassle 1985) compared to the background fauna, with certain species, such as $R$. pachyptila, having rapid growth rates enabling colonisation of new vent habitat (Lutz et al. 1994). Despite relatively low diversity, there have been more than 500 new species described from hydrothermal vents, with more expected to be described as more vent fields are discovered (Desbruyéres et al. 2006). The degree of activity, whether venting is high or low temperature, will also influence the communities present, with different species associated with high and low temperature venting.

The community of background fauna colonising inactive deposits has not been as well studied with the majority of research effort being directed at vent communities. The background fauna resembles fauna of seamount communities with organisms typically being sessile, filter-feeding, long lived and slow growing, including taxa such as sponges, hydroids, corals, anemones, squat lobsters, ophiuroids and holothurians (Galkin 1997, Van Dover and Hessler, 1990 Collins et al. 2012). These taxa take advantage of the hard substrata provided by inactive SMS deposits.

There have not been any studies to date confirming or refuting the existence of the third community, the hypothesised specialised fauna hosted by weathering inactive deposits. Van Dover (2007) has noted that there are species that have been described from inactive sulfide deposits, including the polynoid polychaete, Eunoe alvinella, and the archaeogastropod limpets Neolepetopsis verruca and Neolepetopsis densata, although whether these species are restricted to particular inactive deposits remains to be seen.

\subsection{Faunal distribution at SMS deposits}

At the deposit scale, biological communities show distinct zonation in relation to distance from hydrothermal vent emissions. There is a central vent zone dominated by vent fauna, a distal vent zone with maximum densities of non-vent fauna and a non-vent impact zone with higher densities of non-vent fauna relative to regional values (Arquit 1990). The 
distance at which these zones occur in relation to active hydrothermal venting will differ between SMS deposit sites. For example, at Snake Pit, MAR, the central vent zone occurred within $10-80 \mathrm{~m}$ of active black smoker chimneys and the distal vent zone occurred 120 - 180 m from active chimneys (Sudarikov and Galkin 1995). At Ashes vent field, JdFR, the central vent zone extended for $100 \mathrm{~m}$ from the vents, the distal vent zone occurred at $100-725 \mathrm{~m}$ and the non-vent impact zone extended from $725-1300 \mathrm{~m}$ (Arquit 1990). The high density of fauna around vent sites relative to background levels, known as the 'halo' effect, also occurs in the Manus Basin, PNG. Inactive SMS deposits in the vent periphery were found to host a range of invertebrates with greater densities (Galkin 1997), including sponges, hydroids, corals, anemones, squat lobsters, ophiuroids and holothurians. High densities of background fauna in proximity to vents are thought to occur through enhanced food supply, with tissue stable isotope values indicating the contribution of a chemosynthetic food source to halo fauna diet (Erickson et al. 2009).

The geochemical environment also varies within single active deposits, with a complicated micro-distribution of habitat patchiness supporting complex distributions. For example, at hydrothermal vents on the East Scotia Ridge the faunal assemblage consisting of Kiwa sp., gastropods, barnacles and anemones displayed zonation at both within-chimney and between-chimney scales (Marsh et al. 2012).

\subsection{Global biogeography of SMS communities}

SMS communities often exist in relative isolation with distances of anything between 100s and 1000 s of $\mathrm{km}$ between vent fields, potentially restricting genetic mixing between sites through limited larval dispersal. On a global scale, tectonic processes can isolate hydrothermal vent fields over millions of years, leading to speciation and the formation of unique biological communities that can be broadly separated into biogeographic provinces (e.g. Van Dover et al. 2002).

The patchy nature of sampling within hydrothermal settings has led to an evolving appreciation of hydrothermal vent biogeography with province boundaries re-defined as sampling effort has increased and new hydrothermal vent fields have been discovered. The first biogeographic province model had seven provinces (Tunnicliffe 1997), whilst subsequent models identified four (Mironov et al. 1998), five (Moalic et al. 2012), six (Van Dover et al. 2002, Bachraty et al. 2009), and eight provinces (Tunnicliffe et al. 1998, Tyler and Young 2003). A recent review by Rogers et al. (2012) proposes a total of 11 biogeographic provinces (Fig. 2) comprising the Mid-Atlantic Ridge (MAR), East Scotia Ridge (ESR), Northeast Pacific (NEP), North East Pacific Rise (NEPR), South East Pacific 
Rise (SEPR), South of the Easter Microplate (SEM), Indian Ocean (IO), Northwest Pacific (NWP), West Pacific (WP), Central/Southwest Pacific (CSWP) and the Kermadec Arc (KA). These provinces are distinguished by faunal composition and structure of the vent communities, and particularly by their most abundant species.

As more vent fields are discovered, more biogeographic provinces may be identified or increased sampling could better define gradients and lead to fewer separate provinces. It is also possible that some locations will be identified to be of particular importance as sources or stepping stones for the dispersal of fauna amongst the distinct provinces (Moalic et al. 2012).

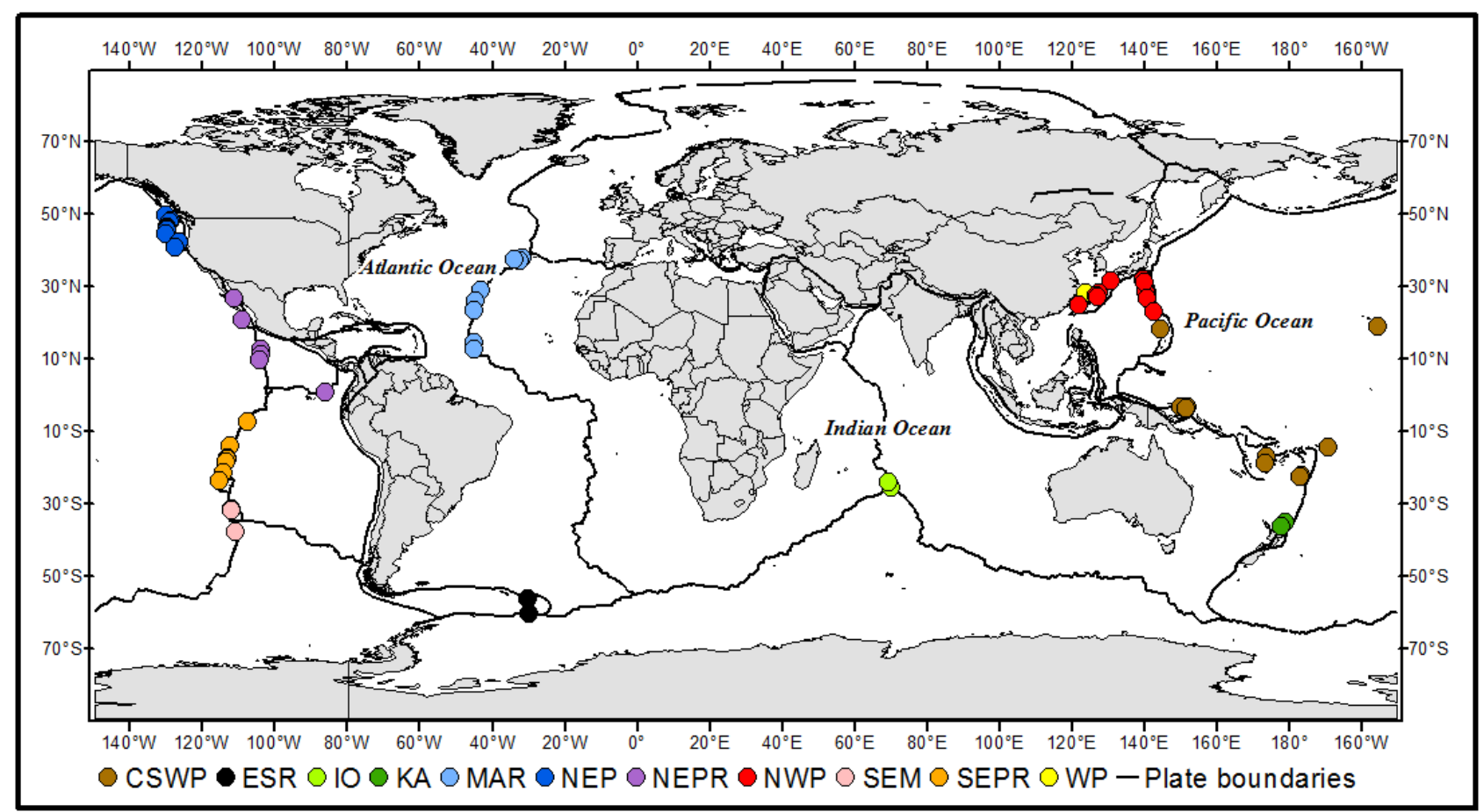

Figure 2. Map of the global biogeography of hydrothermal vents communities, after Rogers et al. (2012). Abbreviations are CSWP: Central South West Pacific, ESR: East Scotia Ridge, IO: Indian Ocean, KA: Kermadec Arc, MAR: Mid Atlantic Ridge, NEP: Northeast Pacific, NEPR: North East Pacific Rise, NWP: North West Pacific, SEM: South of the Easter Microplate, SEPR: South East Pacific Rise, WP: Western Pacific.

\subsection{Connectivity of SMS deposit populations}

Population connectivity (defined here in terms of genetic connectivity as opposed to demographic connectivity) is controlled by a suite of factors, including the local hydrographic regime, the distance between sites, small spatial-scale habitat suitability, the evolutionary history of the population in question, and life history characteristics (Gardner et al. 2010, Reisser et al. 2011, Wei et al. 2013). The connectivity and dispersal of 14 vent 
endemic species was reviewed by Vrijenhoek (1997), who suggested that vent species fall under four models of connectivity and dispersal; 1) the island model, where gene flow occurs without geographical bias; 2) the isolation by distance or stepping-stone model, where genetic differentiation increases with geographical distance; 3) segment-scale divergence, where genetic differentiation is associated with offsets between ridge segments; and 4) ridge-scale isolation, where isolation by distance occurs along a ridge axis. The island model includes species such as Bathymodiolus thermophilus and Calyptogena magnifica; the stepping-stone model includes $R$. pachyptila; segment-scale divergence includes Alvinellid worms and ridge-scale isolation includes the brooding amphipod Ventiella sulfuris.

If populations within a region demonstrate high genetic connectivity then there is mixing between the populations, implying areas disturbed by mining could be recolonized by other populations in the region without significant loss of genetic diversity. Hydrothermal vent fauna populations can demonstrate high levels of genetic connectivity, such as Ifremeria nautilei populations from Manus Basin, where connectivity was assessed using mitochondrial DNA $\mathrm{COI}$ sequence variation and nine nuclear microsatellite markers (Thaler et al. 2011). There was no population structure at patch (within a structure, such as a chimney), mound (between chimneys at a deposit) or site (between deposits) scale (Thaler et al. 2011). This suggests that local populations are highly connected by gene flow. Patterns of apparent genetic connectivity can also depend on the markers used. For example, high connectivity amongst $R$. pachyptila populations along a $4000 \mathrm{~km}$ stretch of the northern EPR and Galapagos Rift was inferred from comparing ten enzyme encoding loci (Black et al. 1994). However, a study using amplified fragment length polymorphisms as a genomic DNA fingerprinting technique found differentiation amongst $R$. pachyptila populations from all regions and within each region, suggesting a more patchy population structure with some individuals separated by just $400 \mathrm{~m}$ being genetically distinguishable (Shank and Halanych 2007). The most recent investigation using one mitochondrial and three nuclear gene loci suggests the connectivity of $R$. pachyptila populations decreases with geographic distance supporting a linear stepping-stone model of dispersal (Coykendall et al. 2011).

The pelagic larval development (PLD) of a species has major implications for population connectivity, with a longer PLD likely to lead to greater population connectivity. As such, the life history characteristics of vent fauna can help explain observed patterns in genetic connectivity between populations. For example, the free-swimming, lecithotrophic Waréns larva of $I$. nautilei, and the subsequent planktotrophic larval stage are thought to 
provide high dispersal capability (Reynolds et al. 2010) and contribute to the lack of population structure (high levels of gene flow) within the Manus Basin (Thaler et al. 2011). When life history characteristics are combined with information on the local hydrographic regime, models can be produced predicting the connectivity of populations. In the case of $R$. pachyptila, its wide dispersal ability results from a long larval life span (average 38 days, Marsh et al. 2001). However, the hydrodynamics can affect dispersal distance. Current reversals at $9^{\circ} \mathrm{N}$ along the EPR restrict dispersal distances to $<100 \mathrm{~km}$ and along axis flow at $13^{\circ} \mathrm{N}$ enables dispersal distances of up to $245 \mathrm{~km}$ (Marsh et al. 2001). The physical structure of an environment will influence the hydrodynamics and hence larval dispersion and population connectivity. For example, there is larval retention within axial valleys at sites along JdFR and Explorer Ridge, where larvae are retained within vent fields or even sections of a ridge (Metaxas 2004). Populations at hydrothermal vents on seamounts also demonstrate high larval retention (Metaxas 2011). For example, along the Mariana and Kermadec Arcs, populations are patchily distributed and spatially constrained (Metaxas 2011).

Populations of vent fauna may be connected with populations from other chemosynthetic environments. Although the majority of vent species have only been found at vent sites, approximately $5 \%$ of vent species have been found at other chemosynthetic environments, including whale falls and seeps, and a further $9 \%$ are found at other nonvent habitats (Wolff 2005). These environments have been controversially proposed as potential 'stepping-stones' for vent fauna, aiding colonisation of chemosynthetic habitat over longer distances (Smith 1989), although this could only be possible for the few species shared between vents and other chemosynthetic environments. Within the New Zealand region, at least one solemyid clam, Acharax clarificata and one sponge, Pseudosuberites sp., have been found at both seeps and active vent sites, with certain genera also shared between seep and active vent sites in the region (Baco et al. 2010). At vent sites on the MAR, the ophiuroid Ophioctenella acies was found only at active vents (Tyler et al. 1995, Stöhr and Segonzac 2005), whilst the other four ophiuroids at active vent sites, Ophiactis tyleri, Ophiocten centobi, Ophiomitra spinea and Ophiotreta valenciennesi rufescens, were also found in neighbouring non-vent habitats (Stöhr and Segonzac 2005). In addition, O. acies is known to inhabit methane seeps in the northwest Atlantic (Van Dover et al. 2003). 


\subsection{Recolonization of SMS deposits}

Hydrothermal vent species are vulnerable to habitat loss through mining activities but if vents remain active following disturbance, deposits could re-build. Rapid re-growth of chimneys was observed during exploration of proposed mining sites at Solwara 1 in PNG, where $58 \mathrm{~cm}$ of new chimney lattice formed within 12 months and in one case, $60 \mathrm{~cm}$ formed within 2 days of disturbance (Coffey Natural Systems 2008a). In time, these new deposits could be colonised by fauna from nearby vent communities.

Recolonization of SMS deposits will most commonly occur via transport of larvae as the distances between vent sites are generally too great for colonisation by motile adults. Experiments to investigate recolonization commonly involve the provision of artificial substrata, which are recovered after a certain time and assessed for recruitment. These experiments can be used to deduce temporal and spatial patterns in recruitment and colonisation that can form the basis of predictions about recolonization following mining disturbance. At $9^{\circ} 50^{\prime} \mathrm{N}$ on the EPR, basalt blocks were deployed to assess the influence of neighbouring $R$. pachyptila, Tevnia jerichonana and B. thermophilus colonies on settlement of tubeworms (Hunt et al. 2004). In addition, basalt blocks deployed at the JdFR were used to assess the spatial variation of colonisation and influence of vent fluid properties and biological interactions on the colonisation process (Kelly et al. 2007, Kelly and Metaxas 2008). Colonisation experiments at diffuse vents at Axial Volcano, JdFR, revealed more diverse and rich faunal assemblages colonising complex habitats, such as a sponge-like matrix, than the basalt-like substrate most similar to the seafloor (Kelly and Metaxas 2008).

Natural recolonization events have occurred at a much larger scale than experimental observations, following eruptions along the JdFR (Lutz et al. 1994) and EPR at $9^{\circ} \mathrm{N}$ (Tunnicliffe et al. 1997), which killed the established vent communities. These large scale natural events point to a rapid recolonization by vent fauna, with JdFR vents recolonised by the dominant taxon Ridgeia piscesae within 7 months, and a return of onethird of the regional vent species pool within 2 years (Tunnicliffe et al. 1997). At $9^{\circ} \mathrm{N}$, EPR, $30 \mathrm{~cm}$ long $T$. jerichonana and $1.5 \mathrm{~m}$ long $R$. pachyptila were established within $1 \mathrm{yr}$ and 2 yr respectively (Lutz et al. 1994) demonstrating rapid growth rates. Such rapid recolonisation can only occur where re-colonising organisms are able to disperse across the distance between vent communities or where a section of the community is retained to seed new populations (Tunnicliffe et al. 1997), as in the case of $9^{\circ} \mathrm{N}$ where re-colonisation was thought to occur from surviving adults (Haymon et al. 1993), revealing the importance of self-recruitment to the settlement and recolonization process. Recolonization may occur 
more slowly at sites where populations are patchily distributed and spatially constrained with high larval retention, such as at hydrothermal vents on seamounts along the Mariana and Kermadec Arcs (Metaxas 2011). Such populations have high local recruitment but low potential for colonisation of new locations (Metaxas 2011) suggesting a limited ability to recolonise areas disturbed by mining activity.

Recolonization may not always be by the same species that comprised the original vent community. Following an eruption at EPR 9 56' N in 2006 (Tolstoy et al. 2006), there was significant change in the species composition of larval supply and colonists compared with the larval supply and colonists prior to the eruption. As all biological communities at active SMS deposits were removed between $9^{\circ} 47^{\prime} \mathrm{N}$ and $10^{\circ} 08^{\prime} \mathrm{N}$, colonising larvae must have been supplied from more distant vent communities, resulting in a shift in community composition (Mullineaux et al. 2010).

\subsection{Recovery potential}

Information on the connectivity of populations and the recolonization ability of species can inform assessment on the recovery potential for populations disturbed by mining activity. Unfortunately there are few species from SMS deposits where both the population connectivity and recolonization potential have been assessed. Certain species appear to have a high recovery potential, such as $I$. nautilei within the Manus Basin, where high levels of population connectivity (Thaler et al. 2011) suggest individual populations have a relatively high recovery potential with mining activity likely to have a minimal impact on genetic diversity within the region. Other species, with different life history characteristics and dispersal mechanisms, could be more vulnerable to disturbance. $R$. pachyptila population connectivity decreases with geographic distance, supporting a suspected 'stepping-stone' method of dispersal (Coykendall et al. 2011), meaning that recolonization could be prevented if one of the 'stepping-stones' is removed by mining activity. Hence, despite the rapid growth rate of $R$. pachyptila, its ability to rapidly recolonise areas subjected to natural disturbance (Lutz et al. 1994) and its long larval life span (Marsh et al. 2001), it may have a lower recovery potential than I. nautilei.

The rates of recovery of benthic communities are likely to vary between fast- and slow-spreading sites, with fast-spreading sites likely to rebuild deposits through hydrothermal activity quicker leading to suitable habitat for recolonization becoming more rapidly available. Arc systems, such the Mariana and Kermadec Arcs, are thought to have a lower recovery potential than mid-ocean spreading centres as a result of the patchily distributed and spatially constrained populations (Metaxas 2011). Whilst recolonization 
following mining-induced disturbance may be relatively quick at some locations, natural disturbances will continue alongside those attributable to mining (Van Dover 2011), with the compound effect of anthropogenic and natural disturbances likely to increase the recovery time for active deposit communities.

The possibility of 'stepping-stone' refuges for vent species in the form of other chemosynthetic habitats could increase the recovery potential for species found in multiple chemosynthetic environments. These refuges would only be available to the few species found in multiple habitats, with the rest of the SMS community potentially having a lower recovery potential. An example is the ophiuroid fauna at vent sites along the MAR (Tyler et al. 1995, Van Dover et al. 2003, Stöhr and Segonzac 2005), where similar species within the same community may have different recovery potential from disturbance, in part due to the possible role of refuge sites. The existence of ranges in recovery potential within the same community makes it difficult to generalise the recovery potential of vent communities as a whole.

Although widespread background fauna are not endemic to inactive SMS deposits, and their populations are potentially not as vulnerable to habitat loss as vent specialists, background fauna tend to have slower growth rates than vent specialists and as a consequence the recovery times from disturbance are expected to be longer (Van Dover 2011). The recovery time for background fauna is likely to be on the timescale of years or even decades, with similar megafaunal assemblages at seamounts that have been subjected to trawling showing no signs of recovery over a 5 to $10 \mathrm{yr}$ period following the cessation of disturbance (Williams et al. 2010).

If the hypothesised community containing specialist fauna at inactive deposits is found to exist, then this community would be the group most vulnerable to disturbance from mining activity. These fauna are likely to be restricted to specific deposits and will suffer habitat loss without the prospect of inactive deposits being replaced through hydrothermal activity. Until the existence of this community is confirmed, its potential for recovery is impossible to predict.

\section{Impacts of SMS mining on the benthic community}

Mining of SMS deposits consists of three stages, prospecting, exploration and exploitation, all of which have associated impacts. Prospecting is the search for SMS deposits, including an estimation of deposit size, distribution, composition and economic value. Exploration follows prospecting and involves the analysis of defined deposits, the use and testing of mining equipment and facilities and undertaking environmental, technical, 
economic and commercial studies. The final exploitation phase involves the recovery for commercial purposes of SMS and the extraction of the minerals contained, including the construction and operation of mining, processing and transportation systems (International Seabed Authority 2010).

To date, no commercial SMS mining activity has occurred anywhere in the world. The lack of a precedent makes it difficult to predict the potential impacts (Coffey Natural Systems 2008b). According to the International Seabed Authority (2011), impacts will also be different at the various mining stages, with exploitation likely to have a high-intensity of direct impact, a local scale of spatial activity $(<1000 \mathrm{~m})$ and an activity duration of years. The probability of an accidental event causing environmental damage is small, although the persistence of impact following mining activity could continue for decades in the absence of effective mitigation or restoration activities (International Seabed Authority 2011).

Impacts of SMS mining are predicted to occur across all marine environments (benthic, bathypelagic, mesopelagic and epipelagic) ranging from site to regional scale over both short and prolonged durations (summarised in Table 2) (Coffey Natural Systems 2008b). Within the benthic environment alone, there is a range of habitats including both hard and soft substrata with different communities residing on or in each. The benthic organisms also span a range of sizes, including the microfauna $(<63 \mu \mathrm{m})$, meiofauna, (63 $-500 \mu \mathrm{m})$, macrofauna $(500 \mu \mathrm{m}-5 \mathrm{~cm}$ ) and megafauna $(>5 \mathrm{~cm})$, with different ecological characteristics, including the nature and extent of dispersal, mobility, feeding strategies and trophic interactions. Such a suite of habitats, faunal assemblages and ecologies means that the response of benthic organisms to SMS mining will vary widely, complicating any attempt to generalise the identification and mitigation of impacts. The nature and the scale of those impacts (both spatial and temporal) are also likely to be different at different deposits. Table 2 summarises the only site-specific impact assessment currently available (see Coffey Natural Systems 2008b for full assessment), but different sites may have additional impacts to consider. The impacts from SMS mining will also vary with the methods and equipment used. For example, the predicted impacts from the proposed SMS mining methods of the Japan Deep Sea Technology Association (DESTA) are more varied with a greater risk of smothering (Fukushima and Okamatsu 2010) than those for Solwara 1 outlined in Table 2. 
Modelling studies of the dispersal of unconsolidated sediment discharge at Solwara 1 indicated that increased sedimentation thicknesses of up to $500 \mathrm{~mm}$ may occur within 1 $\mathrm{km}$ of the discharge site (Coffey Natural Systems 2008b). Some particulate material may extend up to $10 \mathrm{~km}$ from the site, but settle at lower than natural rates. Existing sediment thicknesses at and around Solwara 1 are $6 \mathrm{~m}$ deep in places (Coffey Natural Systems 2008b). Return water plumes may extend $5-10 \mathrm{~km}$ from the mining site, with maximum deposit thickness of $0.1 \mathrm{~mm}$ and rates of settling less than existing deep-sea sedimentation rates (Coffey Natural Systems 2008b). Sediment and water column plumes will disperse with distance, and hence "downstream" effects will be less than at the site where they are formed. This dilution will mean there is a gradient of impact, with effects lessening with distance away from the mining site. The potential distance and depth of sedimentation effects will vary amongst sites, and will need to be assessed in any prospective mining area. With regards to the toxicity of these plumes, it is thought that high concentrations of heavy metals will pose minimal risk to the fauna adapted to active SMS deposits (Coffey Natural Systems 2008b). However, this material may prove toxic to fauna adapted to inactive deposits or the general background fauna.

Impacts specific to benthic communities at SMS deposits were reviewed by Van Dover $(2007,2011)$, and are summarized in Table 3. Alongside the obviously negative impacts of mining, such as the loss of sulfide habitat and biodiversity, the search for commercially viable deposits and the environmental surveys carried out by or for mining companies, will have benefits for science (reviewed by Van Dover 2007, 2011). The discovery of new SMS sites will occur at a faster pace, and there will be an improved understanding of SMS deposit ecology through the involvement of scientists in impact assessment studies and long term monitoring programs. Through industry-led scientific programs, new species could be discovered and the knowledge of life in extreme environments will expand. 
Table 2. Summary of the potential impacts on the biological environment from SMS mining at Solwara 1, PNG, summarised from Coffey Natural Systems (2008b). Environment classifications: benthic (seafloor); bathypelagic (water column > $1000 \mathrm{~m}$ ); mesopelagic (water column $200-1000$ $\mathrm{m}$ ); epipelagic (water column $<200 \mathrm{~m}$ ). Spatial scales: site $(<1 \mathrm{~km}$ from project location); local (1 $10 \mathrm{~km})$; regional $(>10 \mathrm{~km})$. Temporal scale: short duration $(<1 \mathrm{yr}$, generally for duration of project); prolonged (> $1 \mathrm{yr}$ after completion of project).

\begin{tabular}{|c|c|c|}
\hline Environment & Impact & Scale \\
\hline \multirow[t]{8}{*}{ Benthic } & $\begin{array}{l}\text { Change in seafloor surface structure from habitat } \\
\text { removal }\end{array}$ & $\begin{array}{l}\text { Site, short duration - } \\
\text { prolonged }\end{array}$ \\
\hline & $\begin{array}{l}\text { Smothering of organisms by sediment plume } \\
\text { generation from seafloor mining tool activity }\end{array}$ & Site, short duration \\
\hline & Change in species diversity from organism loss & $\begin{array}{l}\text { Site, short duration - } \\
\text { prolonged }\end{array}$ \\
\hline & $\begin{array}{l}\text { Smothering of organisms from loss of material from } \\
\text { riser transfer pipe }\end{array}$ & Site, short duration \\
\hline & $\begin{array}{l}\text { Loss of adjacent communities by changed } \\
\text { hydrothermal activity }\end{array}$ & $\begin{array}{l}\text { Site, short duration - } \\
\text { prolonged }\end{array}$ \\
\hline & $\begin{array}{l}\text { Smothering effects of plumes discharged at depth } \\
\text { from dewatering }\end{array}$ & Local, short duration \\
\hline & Reduced water quality from hydraulic leak & Site, short duration \\
\hline & $\begin{array}{l}\text { Toxic effects on benthic organisms from loss of } \\
\text { material from riser transfer pipe }\end{array}$ & Site, short duration \\
\hline \multirow[t]{3}{*}{ Bathypelagic } & $\begin{array}{l}\text { Toxic effects of plumes discharged at depth from de- } \\
\text { watering }\end{array}$ & $\begin{array}{l}\text { Local, short duration - } \\
\text { prolonged }\end{array}$ \\
\hline & $\begin{array}{l}\text { Loss of organisms attracted to suction area by SMT } \\
\text { lights }\end{array}$ & Site, short duration \\
\hline & Reduction of bioluminescence by plume generation & Local, short duration \\
\hline \multirow[t]{2}{*}{$\begin{array}{l}\text { Bathypelagic, } \\
\text { mesopelagic, } \\
\text { epipelagic }\end{array}$} & $\begin{array}{l}\text { Toxic effects on pelagic biota, including } \\
\text { bioaccumulation from release of metals into water } \\
\text { column }\end{array}$ & $\begin{array}{l}\text { Local - regional, short } \\
\text { duration }\end{array}$ \\
\hline & $\begin{array}{l}\text { Disturbance of cetaceans by noise from mining and } \\
\text { vessel equipment }\end{array}$ & $\begin{array}{l}\text { Local - regional, short } \\
\text { duration }\end{array}$ \\
\hline \multirow[t]{3}{*}{ Epipelagic } & $\begin{array}{l}\text { Nutrient increase and increased productivity from } \\
\text { discharge of macerated waste and treated sewage }\end{array}$ & Site, short-duration \\
\hline & $\begin{array}{l}\text { Toxic effects from spillage of ore or hazardous } \\
\text { material from the mining surface vessel }\end{array}$ & Site, short duration \\
\hline & $\begin{array}{l}\text { Death of indigenous fauna resulting from exotic } \\
\text { species introduction via ballast water and hulls }\end{array}$ & Regional, prolonged \\
\hline
\end{tabular}


Table 3. Potential impacts on the benthic community from mining activities, combined from Van Dover $(2007,2011)$.

\begin{tabular}{|l|}
\hline Potential impacts on the benthic community from mining activities \\
\hline Loss of sulfide habitat \\
\hline Degradation of sulfide habitat quality \\
\hline Modification of fluid flux regimes \\
\hline Local, regional, or global extinction of endemic or rare taxa \\
\hline Decreased diversity (at all levels: genetic, species, phylogenetic, habitat, etc.) \\
\hline Decreased seafloor primary production \\
\hline Modification of trophic interactions \\
\hline Risk of transplanting organisms from one mining site to another \\
\hline Exposure of surrounding seafloor habitats (non-sulfide) to sediment and heavy metal deposition \\
\hline Cumulative impacts of multiple habitat loss events within a region \\
\hline Lost opportunity to gain knowledge about what is currently not known \\
\hline
\end{tabular}

\section{International and national regulation of SMS mining}

The management of SMS mining is controlled by different legislation according to the jurisdiction under which the proposed mining project falls. Within the EEZ or legal continental shelf of a country, all mining regulation and management falls under national jurisdiction. All seabed that does not fall within the EEZ or legal continental shelf of a country is termed 'the Area' and is managed by the International Seabed Authority (ISA) as determined by the 1982 United Nations Convention on the Law Of the Sea. All States party to the Convention must apply to the ISA for licences to prospect, explore and exploit mineral resources in the Area. The ISA has issued regulations governing prospecting and exploration for SMS deposits, which were adopted in May 2010 (International Seabed Authority, 2010). Contractors must establish environmental baselines against which impacts from mining activities can be assessed, carry out environmental monitoring programmes, and take measures to prevent, reduce, and control pollution and other hazards to the marine environment (see sections 6 and 7). Contractors must assess if serious harmful effects to vulnerable marine ecosystems, such as those associated with hydrothermal vents, will occur as a results of mining activity, and applications for mining can be rejected where substantial evidence indicates the risk of serious harm to the marine environment.

Other international conventions, such as the Stockholm Declaration (1972) (http://www.unep.org/Documents), the Rio Declaration (http://www.unep.org/Documents), the Convention on Biodiversity (http://www.cbd.int/convention/text/) and the World Summit on Sustainable Development (2002) (http://www.un.org/isummit/html/documents/summit docs.html), influence the drafting of marine mining legislation by signatory countries. The Stockholm and Rio 
Declarations emphasise the need for environmental protection and environmental impact assessment in sustainable development, alongside the need to share scientific knowledge and adopt the 'precautionary principle'. The Convention on Biodiversity also supports the precautionary principle alongside endorsing an ecosystem approach to management and area-based management tools. The World Summit on Sustainable Development calls for representative networks of marine protected areas to promote conservation and management of the oceans.

As well as legislation, there are two main codes of conduct issued by stakeholder groups that are concerned with activities at SMS deposits; the InterRidge Statement of Commitment to Responsible Research Practices (Devey et al. 2007, http://www.interridge.org/IRStatement) and the International Marine Minerals Society (IMMS) Code for Environmental Management of Marine Mining (International Marine Minerals Society 2011). The InterRidge Statement acknowledges that scientific research can affect communities at hydrothermal vents and signatories agree to avoid activities that can impact the sustainability of vent communities or lead to long-term degradation of vent sites, including avoiding non-essential collections and transplanting material between sites. The IMMS Code consists of a statement of environmental principles for marine mining and operating guidelines for application by industry, regulatory agencies, scientists and other interested parties. It is a voluntary code that aims to encourage environmental best practice and transparency in commercial operations. The Code also emphasises the precautionary approach, the involvement of local and scientific communities and responsible and sustainable development. The Code emphasises a need to "consider biological resource potential and value of living organisms at potential marine mining sites as well as the mineral resource potential and value". The IMMS Code also highlights the need for procedures that aid in the recruitment, re-establishment and migration of biota following mining activities and supports the study of undisturbed, comparable habitats that are close to the mining site before, during and after mining activities.

The only SMS mining project to date that has been granted a mining lease is within the territorial waters of $P N G$ and is principally governed by two items of national legislation, the Mining Act (1992) and the Environment Act (2000). The Mining Act declares all minerals to be owned by the national government and controls all exploration, processing and transport of minerals. The Environment Act is administered by the Department of Environment and Conservation (http://www.dec.gov.pg/legislation.html) and requires an Environmental Impact Statement (see section 6.0) prior to permits for mining being granted, with further conditions including installation of monitoring equipment, 
undertaking an environmental management program, baseline studies and a rehabilitation program. An area where mining is still at the exploratory stage is within the NZ EEZ, which falls under two pieces of national legislation. The Crown Minerals Act 1991 legislates for minerals within the 12 nautical mile limit, but the potential sites for SMS mining exists beyond this, yet still within the EEZ. The Exclusive Economic Zone and Continental Shelf (Environmental Effects) Act (2012) manages the environmental effects of numerous activities, including SMS mining, beyond the 12 nautical mile limit. The Act has only recently been enacted, and regulations governing activities are still being developed (as of June 2013).

\section{Management of SMS mining}

\subsection{Management Objectives}

Management of mining at SMS deposits will depend on the development of objectives that that are specific to a country or to a particular situation. However, most management objectives will aim to balance the exploitation of resources and conservation of SMS ecosystems. These objectives will drive the subsequent science and management measures necessary to avoid, mitigate and remedy impacts. Management objectives should include conservation goals for ecosystems associated with SMS deposits (Van Dover et al. 2012), such as "to protect the natural diversity, ecosystem structure, function and resilience of... vent communities" (International Seabed Authority 2011), whilst enabling responsible utilisation of mineral resources.

\subsection{Environmental Impact Assessment}

Assessing and predicting the potential impacts of SMS mining on the marine environment is a requirement of the ISA regulations (International Seabed Authority 2010) and the Stockholm and Rio Conventions. An environmental impact assessment (EIA) usually includes an initial 'desk-top' scoping study, and field-based environmental or baseline surveys and an ecological risk assessment (ERA) (Collins et al. 2013a). EIA involves evaluating the probable environmental impacts of a proposed project or development, taking into consideration beneficial and adverse socio-economic, cultural and humanhealth impacts. Following identification of potential impacts, the likelihood of events occurring and the potential severity of those impacts are used to estimate risk. Based on this assessment of risk, mitigation strategies can be proposed that either reduce the likelihood of events occurring or reduce their potential severity, and hence the overall risk associated with the activity. As such, the potential impacts associated with SMS mining will 
vary according to the proposed mining methods. The results of the EIA (including the effects of proposed activities and any mitigation strategies) are summarised in an Environmental Impact Statement (EIS). The EIS is a document that incorporates an overall assessment of the mining project, providing managers with proposed measures to minimise environmental impact and maximise legislative compliance (Collins et al. 2013a). General recommendations (a "template") for EIS were developed at a specific ISA workshop (International Seabed Authority 2012) and it is expected that any EIS submitted to the ISA will "substantially comply" with these recommendations (International Seabed Authority 2012). The general template includes a need for description of the offshore environment, including the biological environment. There should be a description of the effects on individuals, communities, populations and metapopulations, within the pelagic, mid-water and benthic environments. Developers must also submit an Environmental Management Plan, including sections on mitigation and management, monitoring, and reporting.

\subsection{Mitigation strategies}

Mitigation strategies vary according to what part of the environment they are trying to protect and the nature and extent of impacts of the mining. In the case of benthic communities, there are two main potential impacts from SMS mining, although there are also many others (see section 4.0). The first is the loss of all organisms in the immediate area of mining operations and the second is the smothering of organisms in the general vicinity by potentially toxic sediment plumes. For the first, proposed mitigation strategies should aim at maximising the potential for recolonization of areas impacted by mining from surrounding populations and the preservation of undisturbed communities similar to the impacted community. For the second, mitigation strategies should aim at reducing the concentration, size and toxicity of particles in sediment plumes associated with various mining activities.

Enhancing the recruitment and re-establishment of biota following mining is one of the recommendations of the IMMS Code (International Marine Minerals Society 2011). This can be achieved through 'set aside' areas, used exclusively as 'impact reference zones" and "preservation references zones" as stipulated by the ISA (International Seabed Authority 2010). Impact reference zones are used to assess the effects of activities on the marine environment whilst preservation reference zones are areas where there is no mining to ensure representation of an un-impacted seabed biota. These sites should be upstream, support a similar biological community and be far enough away not to be 
impacted by mining, yet close enough to supply colonising larvae to the impacted site (Van Dover 2007). For example, off PNG the South Su reference site is located $2 \mathrm{~km}$ upstream of the Solwara 1 mining site and has a similar biological community to the mining site, suggesting it could act as a suitable set aside site and an effective supply of larvae for recolonization of Solwara 1 (Collins et al. 2012). Nautilus Minerals Inc., the company licenced to mine off PNG, also proposes to enhance recolonization through quasipermanent refuge areas, where the temperature is too great for the seafloor mining tool to operate $\left(>35^{\circ} \mathrm{C}\right)$, and temporary refuges. Temporary refuge sites will not be mined until there are signs of recovery from mining activity at other sites, enabling local retention of organisms that could supply recently mined zones in Solwara 1 with colonising larvae. Nautilus also propose to re-locate fauna from mined sites to temporary refuges or even outside of the mining area to help retain an adult spawning population that would aid recolonization. In addition, Nautilus propose to deploy artificial hard substrata for recolonization by slow-growing sessile taxa such as corals in regions where inactive SMS deposits have been mined (Coffey Natural Systems 2008b). However, the colonising communities will probably differ according to the substrate provided (Kelly and Metaxas 2008), which should be taken into consideration. There is also a range in life history characteristics and so recolonization potential of species at SMS deposits, which must be considered when formulating management or mitigation strategies.

Reducing the concentration, size and toxicity of particles in sediment plumes can be achieved through modifications to mining equipment or procedures. In the case of Nautilus (Coffey Natural Systems 2008b), the suction mouth of the seafloor mining tool is designed for minimal escape of suspended material during cutting. The material returned to the bathypelagic environment following dewatering at the surface is planned to contain material $<8 \mu \mathrm{m}$ in diameter, reducing both the grain size and quantity of sediment able to contribute to smothering effects. Assessment of natural suspended sediment concentrations within the area to be mined suggests that the benthic community may have adapted to a relatively high suspended sediment environment, with the additional sediment load from mining activity potentially having little effect (Coffey Natural Systems 2008b). By reducing the escape of suspended material through suction mouth design, minimising the time that waste from dewatering spends at the surface undergoing geochemical change and releasing this waste $25-50 \mathrm{~m}$ above the seabed, the risk of exposure to toxic plumes is limited (Coffey Natural Systems 2008b).

As well as site or deposit scale mitigation measures, such as set aside areas and modifications to mining equipment, there is also a need for larger scale mitigation 
measures as part of spatial management. It is important to identify spatial management goals for SMS communities at various levels, including site, deposit, region and even biogeographic province level. Spatial management of SMS sites through a series of open and set aside sites (i.e. closed areas) would ensure the retention of undisturbed examples of the SMS communities targeted by SMS mining. Set aside areas should ideally be present as part of a larger network of protected areas to enable ecosystem level conservation. Networks of chemosynthetic ecosystem reserves (CERs) have been proposed as a way to protect the diversity, structure, function and resilience of these ecosystems alongside managing the use of the ecosystem's mineral resources (International Seabed Authority 2011). Any network of protected areas should also be distributed amongst biogeographic provinces in order to ensure adequate representation of the different faunas (International Seabed Authority 2011). For example, tubeworm and clam dominated communities of the South East Pacific Rise Province (Corliss et al. 1979, Spiess et al. 1980) may respond differently to disturbance compared to shrimp and mussel dominated communities of the Mid-Atlantic Ridge Province (Murton et al. 1995) or the Kiwa crab and stalked barnacle communities of the East Scotia Ridge Province (Rogers et al. 2012). The relative sizes of these provinces may also contribute to their vulnerability to disturbance. Smaller biogeographic provinces, such as the Kermadec Arc province, NZ, may be more vulnerable to localised and total extinctions, although as more vent fields are discovered the relative sizes of provinces may change. The spatial design of CERs at hydrothermal vents hosting SMS deposits should follow the Dinard Guidelines, as outlined by the International Seabed Authority (2011). The first marine protected area designated for its hydrothermal vent fields, the "Endeavour Hydrothermal Vents Marine Protected Area," is also the world's first CER, containing five vent fields split between four management areas catering for observational research, education and outreach and more intrusive research (http://www.pac.dfo-mpo.gc.ca/oceans/protection/mpazpm/endeavour/docs/EHV-CHE-mgmtplan-gestion-eng.pdf).

\section{Methods to investigate and manage impacts from SMS mining}

\subsection{Baseline studies}

There needs to be a comprehensive baseline study carried out before any mining operation begins, in order to measure the subsequent impacts of mining at a site (International Seabed Authority 2010, International Marine Minerals Society 2011). The study should assess the marine environment at and in the vicinity of the proposed site, and should take into consideration seasonal and inter-annual variation in environmental 
parameters. As well as data on the geophysical, geochemical, geological and oceanographic environment, this baseline study needs to comprehensively describe the biological communities. In the case of the benthic fauna, this should include faunal distribution patterns, population connectivity and ecological characteristics relevant to vulnerability and recovery potential. Detailed recommendations for the baseline part of the environmental study were developed by a specific ISA workshop (International Seabed Authority 2004) and were recently reviewed at an international workshop, VentBase 2012 (Collins et al. 2013b, http://www.ventbase.org/).

Faunal distribution patterns at SMS deposits are closely linked to the geochemical environment, with different communities existing at active and inactive deposits. A single mining site is likely to contain numerous active and inactive deposits, leading to complicated within-site faunal distribution patterns. To investigate both within-site and within-deposit faunal distribution patterns, biological communities should ideally be observed in situ using video or still image transects collected by manned/unmanned submersibles or towed camera equipment (Collins et al. 2013a). The subsequent distribution maps can be used to infer potential connectivity between populations, inform targeted biological sampling and link the distribution of fauna with hydrothermal emissions and/or particular substrates. Knowledge of such associations twinned with distribution maps of active and inactive SMS deposits along imaged transects can then be used to predict the distribution of faunal communities in un-surveyed areas across the mining site and its vicinity. These maps can help plan the distribution of mining and set aside areas, minimising disturbance to important habitat and communities.

Ecotoxicological investigations should form an important part of the baseline study, in particular in establishing acceptable concentrations of heavy metals from discharge of mining waste. For example, the high natural background levels of heavy metals at Solwara 1 led to the conclusion that the proposed concentrations of mining waste discharge would not have any measurable effects on the highly-adapted, specialised hydrothermal vent fauna (Coffey Natural Systems 2008b). However, the background fauna and fauna at inactive SMS deposits are not adapted to a high heavy metal environment and could be vulnerable to mining waste discharge. One of the issues with standard ecotoxicology studies and bioassays is that the test organisms are generally from shallow water environments, so the effect of physiological adaptations to the deep-sea environment (pressure, darkness, cold) is not considered. For example, the test organisms used by Nautilus for ecotoxicology tests were the alga Nitzshia closterium, the marine copepod Acartia sinjiensis, and the amphipod Mekita plumulosa, none of which occur at Solwara 1 
(Coffey Natural Systems 2008b). The alternative would be to use deep-sea organisms, preferably those found at inactive SMS deposits or as background fauna, but maintaining these organisms at appropriate environmental conditions throughout a bioassay would be challenging and the cost potentially prohibitive. Acute bioassays could be completed in situ using an ROV but these assays need to be repeated over time to be informative about the chronic and accumulative effects of mining waste discharge.

\subsection{Long-term monitoring}

The effects of SMS mining need to be continually assessed as part of a long-term monitoring programme (International Seabed Authority 2010). Co-operation with the ISA in the monitoring of environmental impacts is explicit in the applications for both prospecting and exploration by contractors in the Area. Annual reports detailing the implementation and results of the monitoring programme are mandatory, ensuring impacts from mining are constantly reviewed and assessed (International Seabed Authority 2010). The proposed mining at Solwara 1 in PNG is also subject to national requirements for monitoring programmes under the Environmental Act 2000, with Nautilus having developed a detailed plan both for baseline studies and subsequent monitoring (Coffey Natural Systems 2008b).

Monitoring programs will utilise baseline data to measure any changes in the environment as a result of mining activity. For example, faunal distribution surveys can be repeated and the maps generated compared with baseline survey data to quantify changes in the spatial extent of key species over time in response to SMS mining. Settlement plates can be deployed to assess whether the colonising community has the same species composition as the previous community and/or set aside area. Genetic analysis comparing the fauna colonising artificial or newly-generated natural substrate to the original populations could enable the source of colonisers to be identified and the suitability of set aside areas to be assessed. The monitoring program needs to be implemented at suitable spatial and temporal scales (International Marine Minerals Society, 2011), although the appropriate length of long-term study required is at present unclear. Levels of natural variation need to be evaluated before any appreciable operations begin, in order to establish fluctuations that could, for example, be seasonal or related to changing chemical conditions. Also, following disturbance, succession of species composition and abundance is to be expected, and so any monitoring must span sufficient time. Recovery from natural disturbance at sites along the EPR (Lutz et al. 1994, Mullineaux et al. 2010) and Juan de Fuca Ridge (Tunnicliffe et al. 1997) and the rapid regrowth of deposits at Solwara 1 (Coffey Natural Systems 2008a) indicate that monitoring 
for a few years following the cessation of mining activities may be sufficient. However, experimental polymetallic nodule mining resulted in disturbance to the benthic community assemblage for at least 26 years following mining activity (Miljutin et al. 2011), suggesting that in keeping with the precautionary principle, suitable long-term monitoring could be on the scale of decades rather than years.

Monitoring programmes by themselves are all very well, but they need to be evaluated against pre-determined decision rules. The latter will be derived from management objectives, and involve a management response when a monitored parameter value exceeds a certain level. For example, mining may have to stop in an area if sediment plume deposition thicknesses exceed a certain depth.

\subsection{The need for replication}

The design of baseline, impact and long-term monitoring studies also needs to consider the importance of replication to address the natural environmental variability at SMS sites at both temporal and spatial scales. Ideally, this should utilise a design similar to BACl (before-after-control-impact, Green (1979)) or Beyond BACl (Underwood 1991, Underwood 1992), with multiple un-impacted (control or set aside) and impacted (mined) sites (Collins et al. 2013a). However, BACl design at SMS sites will probably be asymmetrical with the potential for multiple un-impacted sites but only one impacted site (Underwood 1991, Underwood 1992), as mining is likely to be concentrated at one site. There is also the question of cost. Coastal or shallow water impact studies may be able to investigate multiple sites but the logistics (time and cost) of investigating multiple sites in deep-sea SMS mining impact studies may be prohibitive. Although costly, replication is as important in forming robust scientific conclusions within the deep sea as it is within the coastal zone and only through using methodologies as rigorous as those in the coastal zone can SMS ecosystems be effectively managed under the precautionary principle (Collins et al. 2013b).

\section{Conclusions}

Although SMS mining is still at the prospecting and exploratory phase, exploitation of SMS deposits will probably occur in the next few years in the Western Pacific. Globally, numerous deposits have been identified from a suite of hydrothermal environments and depths, with a range in deposit size and mineral content. SMS deposits can either be hydrothermally active or inactive, although the distinction between these is not always clear. As well as commercially viable ore, deposits are also host to complex biological 
communities. These include a chemosynthetic community of hydrothermal vent specialists adapted to active deposits and a community of background fauna inhabiting inactive deposits. There is also the potential for another community to exist at inactive deposits adapted to the weathered sulfide habitat. Benthic communities demonstrate complex distributions at deposits, with the vent communities also exhibiting particularly constrained biogeographic patterns. The connectivity, recolonization and potential recovery of populations at SMS deposits have not been studied in detail; vent populations have been investigated at various locations but the ecology of populations at inactive deposits is largely unknown. As there is no precedent for SMS mining, predicting the impacts is challenging. However, impacts are predicted to occur across all marine environments ranging from site to regional scale over short and prolonged durations. The nature of these impacts will vary between deposit locations and with the equipment and methods used. Regulation of SMS mining falls under different legislation according to the jurisdiction under which the proposed project falls. Within the EEZ or legal continental shelf of a country, SMS mining is regulated by national legislation; outside of this, projects are regulated by international instruments implemented by the International Seabed Authority. There are also various codes issued by stakeholders to encourage best practice in activities at SMS deposits. Current regulations generally demonstrate commitment to the protection of the marine environment but without considerably more information on SMS deposit ecology it will be a challenge to make decisions on suitable management and mitigation strategies. Management of SMS mining should include the development of clear management objectives, a comprehensive environmental impact assessment, implementation of suitable mitigation strategies, establishment of a long term monitoring program, and clear decision rules associated with changes. It should be acknowledged that alongside the negative impacts of SMS mining on the communities at deposits, there is also an opportunity for improved understanding of deposit ecology through involvement with industry surveys and assessments and that there is a global need for the minerals found in SMS deposits.

\section{Acknowledgments}

REB and AAR acknowledge the fruitful discussions with VentBase 2012 workshop participants, which helped inform this article. REB is supported by PhD scholarship funding from the National Institute of Water and Atmospheric Research and Victoria University of Wellington. 


\section{References}

Alt JC, Lonsdale P, Haymon R, Muehlenbachs K (1987) Hydrothermal sulfide and oxide deposits on seamounts near $21^{\circ} \mathrm{N}$, East Pacific Rise. Geological Society of America Bulletin 98, 157-168.

Amann H (1985) Development of Ocean Mining in the Red Sea. Marine Mining 5, 103 116.

Arquit AM (1990) Geological and hydrothermal controls on the distribution of megafauna in Ashes Vent Field, Juan de Fuca Ridge. Journal of Geophysical Research-Solid Earth and Planets 95, 12947-12960.

Bachraty C, Legendre P, Desbruyères D (2009) Biogeographic relationships among deepsea hydrothermal vent faunas at global scale. Deep-Sea Research Part IOceanographic Research Papers 56, 1371-1378.

Bäcker H, Schoell M (1972) New Deeps with Brines and Metalliferous Sediments in the Red Sea. Nature Physical Science 240, 153-58.

Baco AR, Rowden AA, Levin LA, Smith CR, Bowden DA (2010). Initial characterization of cold seep faunal communities on the New Zealand Hikurangi margin. Marine Geology 272, 251-259.

Baker ET, German CR (2004) On the global distribution of hydrothermal vent fields. In: German CR, Lin J, Parson LM (eds.) Mid-ocean ridges: Hydrothermal interactions between the lithosphere and oceans. Geophysical Monograph Series 148. American Geophysical Union, Washington, DC, pp 245-266.

Beaulieu SE (2010) InterRidge Global database of active submarine hydrothermal vent fields: prepared for InterRidge, Version 2.0. World Wide Web electronic publication.

Binns RA, Scott SD (1993) Actively forming polymetallic sulfide deposits associated with felsic volcanic rocks in the eastern Manus Back-Arc Basin, Papua New Guinea. Economic Geology 88, 2226-2236.

Black MB, Lutz RA, Vrijenhoek RC (1994) Gene flow among vestimentiferan tube worm (Riftia pachyptila) populations from hydrothermal vents of the Eastern Pacific. Marine Biology 120, 33-39.

Both R, Crook K, Taylor B, Brogan S, Chappell B, Frankel E, Liu L, Sinton J, Tiffin D (1986) Hydrothermal chimneys and associated fauna in the Manus Back-Arc Basin, Papua New Guinea. Eos Transactions American Geophysical Union 67, 489-490.

Cavanaugh CM, Gardiner SL, Jones ML, Jannasch HW, Waterbury JB (1981) Prokaryotic cells in the hydrothermal vent tube worm Riftia pachyptila Jones: possible chemoautotrophic symbionts. Science 213, 340-342. 
Coffey Natural Systems (2008a) Environmental Impact Statement, Solwara 1 project, Nautilus Minerals Niugini Limited, Executive Summary. Coffey Natural Systems, Brisbane, Australia, $42 \mathrm{pp}$.

Coffey Natural Systems (2008b) Environmental Impact Statement, Solwara 1 project, Nautilus Minerals Niugini Limited, Main Report, Vol A. Coffey Natural Systems, Brisbane, Australia, $222 \mathrm{pp}$.

Collins PC, Kennedy R, Van Dover CL (2012) A biological survey method applied to seafloor massive sulphides (SMS) with contagiously distributed hydrothermal-vent fauna. Marine Ecology Progress Series 452, 89-107.

Collins PC, Croot P, Carlsson C, Colaço A, Grehan A, Hyeong K, Kennedy R, Mohn C, Smith S, Yamamoto H, Rowden A (2013a) A primer for the Environmental Impact Assessment of mining at seafloor massive sulfide deposits. Marine Policy 42, 198-209.

Collins PC, Kennedy R, Copley JT, Boschen RE, Forde J, Se-Jong J, Lindsay D, Marsh L, Nye V, Patterson A, Watanabe H, Yamamoto H, Carlsson J, Thaler AD (2013b) VentBase: Developing a consensus among stakeholders in the deep-sea regarding environmental impact assessment for deep-sea mining - a workshop report. Marine Policy 42, 334-336.

Connelly DP, Copley JT, Murton BJ, Stansfield K, Tyler PA, German CR, Van Dover CL, Amon D, Furlong M, Grindlay N, Hayman N, Huhnerbach V, Judge M, Le Bas T, McPhail S, Meier A, Nakamura K, Nye V, Pebody M, Pedersen RB, Plouviez S, Sands C, Searle RC, Stevenson P, Taws S, Wilcox S (2012) Hydrothermal vent fields and chemosynthetic biota on the world's deepest seafloor spreading centre. Nature Communications 3, 620 .

Corliss JB, Baross JA, Hoffmann SE (1981) An hypothesis concerning the relationship between submarine hot springs and the origin of life on Earth. Oceanologica Acta 4 (suppl), 59-69.

Corliss JB, Dymond J, Gordon LI, Edmond JM, von Herzen RP, Ballard RD, Green K, Williams D, Bainbridge A, Crane K, van Andel TH (1979) Submarine thermal springs on the Galápagos Rift. Science 203, 1073-1083.

Coykendall DK, Johnson SB, Karl SA, Lutz RA, Vrijenhoek RC (2011) Genetic diversity and demographic instability in Riftia pachyptila tubeworms from eastern Pacific hydrothermal vents. BMC Evolutionary Biology 11, 96.

Craig H, Horibe Y, Farley KA, Welhan JA, Kim K-R, Hey RN (1986) Hydrothermal vents in the Mariana Trough: results of the first Alvin dives. Eos Transactions American Geophysical Union 68, 44, 1531. 
Crawford AM, Hollingshead SC, Scott SD (1984) Geotechnical engineering properties of deep-ocean polymetallic sulfides from $21^{\circ} \mathrm{N}$, East Pacific Rise. Marine Mining 4, 337354.

de Ronde CEJ, Baker ET, Massoth GJ, Lupton JE, Wright IC, Feely RA, Greene RR (2001) Intra-oceanic subduction-related hydrothermal venting, Kermadec Volcanic Arc, New Zealand. Earth and Planetary Science Letters 193, 359-369.

de Ronde CEJ, Massoth GJ, Butterfield DA, Christenson BW, Ishibashi J, Ditchburn RG, Hannington MD, Brathwaite RL, Lupton JE, Kamenetsky VS, Graham IJ, Zellmer, GF, Dziak RP, Embley RW, Dekov VM, Munnik F, Lahr J, Evans LJ, Takai K (2011) Submarine hydrothermal activity and gold-rich mineralization at Brothers Volcano, Kermadec Arc, New Zealand. Mineralium Deposita 46, 541-584.

Desbruyéres D, Segonzac M, Bright M (2006) (eds.) Handbook of deep-sea hydrothermal vent fauna, 2nd edition. Biologiezentrum der Oberösterreichischen Landsmuseen, Linz, Austria, $544 \mathrm{pp}$.

Devey CW, Fisher CR, Scott S (2007) Responsible science at hydrothermal vents. Oceanography 20, 162-171.

Emery KO, Skinner BJ (1977) Mineral deposits of the deep-ocean floor. Marine Mining 1, $1-71$.

Endeavour Hydrothermal Vents Marine Protected Area Management Plan 2010-2015

[Online]. Available: http://www.pac.dfo-mpo.gc.ca/oceans/protection/mpazpm/endeavour/docs/EHV-CHE-mgmtplan-gestion-eng.pdf (accessed March 15th 2013).

Erickson KL, Macko SA, Van Dover CL (2009) Evidence for a chemoautotrophically based food web at inactive hydrothermal vents (Manus Basin). Deep-Sea Research Part IITopical Studies in Oceanography 56, 1577-1585.

Exclusive Economic Zone and Continental Shelf (Environmental Effects) Act 2012 [Online]. Available: http://www.legislation.govt.nz/act/public/2012/0072/latest/DLM3955428.html (accessed March 15th 2013).

Felbeck H (1981) Chemoautotrophic potential of the hydrothermal vent tube worm, Riftia pachyptila Jones (Vestimentifera). Science 213, 336-338.

Fouquet Y, Charlou JL, Costa I, Donvall JP, Radford-Knoery J, Pellé H, Ondréas H, Lourenço N, Ségonzac M, Tivey MK (1994) A detailed study of the Lucky Strike hydrothermal site and discovery of a new hydrothermal site: Menez Gwen; preliminary results of the DIVA1 Cruise (5-29 May, 1994). InterRidge News 3, 2, 14-17. 
Fouquet Y, Stackelberg UV, Charlou JL, Donval JP, Erzinger J, Foucher JP, Herzig P, Muhe R, Soakai S, Wiedicke M, Whitechurch H (1991) Hydrothermal activity and metallogenesis in the Lau Back-Arc Basin. Nature 349, 778-781.

Francheteau J, Juteau T, Rangan C (1979) Basaltic pillars in collapsed lava-pools on the deep ocean-floor. Nature 281, 209-211.

Fukushima T, Okamatsu A (2010) Current issues in seafloor massive sulfide mining development. Proceedings of the Twentieth International Offshore and Polar Engineering Conference, 20-25th June 2010, Beijing, China. The International Society of Offshore and Polar Engineers (ISOPE), pp 181-185.

Galkin SV (1997) Megafauna associated with hydrothermal vents in the Manus Back-Arc Basin (Bismarck Sea). Marine Geology 142, 197-206.

Gardner JPA, Bell JJ, Constable HB, Ritchie PA, Zuccarello GC (2010) Multi-species coastal marine connectivity: a literature review with recommendations for further research. New Zealand Aquatic Environment and Biodiversity Report 48. Ministry of Fisheries, Wellington, New Zealand, $47 \mathrm{pp}$.

Glasby GP, Wright IC (1990) Marine mineral potential in New Zealand's Exclusive Economic Zone. Marine Mining 9, 403-427.

Grassle JF (1985) Hydrothermal vent animals: distribution and biology. Science 229, 713717.

Green RH (1979) Sampling design and statistical methods for environmental biologists. Wiley, New York, NY, 272 pp.

Halbach P, Blum N, Münch U, Plüger W, Garbe-Schönberg D, Zimmer M (1998) Formation and decay of a modern massive sulfide deposit in the Indian Ocean. Mineralium Deposita 33, 302-309.

Halbach P, Nakamura K, Wahsner M, Lange J, Sakai H, Käselitz L, Hansen RD, Yamanoll M, Post J, Prause B, Seifert R, Michaelis W, Teichmann F, Kinoshitall M, Märten A, Ishibashi J, Czerwinski S, Blum N (1989) Probable modern analogue of Kuroko-type massive sulphide deposits in the Okinawa Trough back-arc basin. Nature 338, 496499.

Hannington M, Jamieson J, Monecke T, Petersen S, Beaulieu S (2011) The abundance of seafloor massive sulfide deposits. Geology 39, 1155-1158.

Hannington M, Petersen S, Herzig P, Jonasson IR (2002) A global database of seafloor hydrothermal systems, including a digital database of geochemical analyses of seafloor polymetallic sulfides: prepared for the International Seabed Authority, central data $\begin{array}{llll}\text { repository, } & \text { Version } & 1.0 & \text { Annline]. }\end{array}$ 
iron.isa.org.jm/images/vents-sulphides/documentation ver1.doc (accessed March $15^{\text {th }}$ 2013).

Hannington MD, Peter JM, Scott SD (1986) Gold in sea-floor polymetallic sulfide deposits. Economic Geology 81, 1867-1883.

Hannington MD, Scott SD (1988) Gold and silver potential of polymetallic sulfide deposits on the sea floor. Marine Mining 7, 271-285.

Haymon RM, Fornari DJ, Von Damm KL, Lilley MD, Perfit MR, Edmond JM, Shanks WC 3rd, Lutz RA, Grebmeier JM, Carbotte S, Wright D, McLaughlin E, Smith M, Beedle N, Olson E (1993) Volcanic eruption of the mid-ocean ridge along the East Pacific Rise crest at $9^{\circ} 45-52^{\prime} \mathrm{N}$ : direct submersible observations of seafloor phenomena associated with an eruption event in April, 1991. Earth and Planetary Science Letters 119, 85-101. Herzig PM, Plüger WL (1988) Exploration for hydrothermal activity near the Rodriguez Triple Junction, Indian Ocean. The Canadian Mineralogist 26, 721-736.

Hoagland P, Beaulieu S, Tivey MA, Eggert RG, German C, Glowka L, Lin J (2010) Deepsea mining of seafloor massive sulfides. Marine Policy 34, 728-732.

Humphris SE, Herzig PM, Miller DJ, Alt JC, Becker K, Brown D, Brugmann G, Chiba H, Fouquet $Y$, Gemmell JB, Guerin G, Hannington MD, Holm NG, Honnorez JJ, Iturrino GJ, Knott R, Ludwig R, Nakamura K, Petersen S, Reysenbach AL, Rona PA, Smith S, Sturz AA, Tivey MK, Zhao X (1995) The internal structure of an active sea-floor massive sulfide deposit. Nature 377, 713-716.

Hunt HL, Metaxas A, Jennings RM, Halanych KM, Mullineaux LS (2004) Testing biological control of colonization by vestimentiferan tubeworms at deep-sea hydrothermal vents (East Pacific Rise, $9^{\circ} 50^{\prime} \mathrm{N}$ ). Deep-Sea Research Part I-Oceanographic Research Papers 51, 225-234.

Independent State of Papua New Guinea Department of Environment and Conservation Legislation [Online]. Independent State of Papua New Guinea Department of Environment and Conservation. Available: http://www.dec.gov.pg/legislation.html (accessed March 15th 2013).

International Marine Minerals Society (2011) Code for environmental management of marine mining [Online]. Available: http://www.immsoc.org/IMMS downloads/2011 SEPT 16 IMMS Code.pdf (accessed March 15th 2013).

International Seabed Authority (2007) Polymetallic sulphides and cobalt-rich ferromanganese crusts deposits: establishment of environmental baselines and an associated monitoring programme during exploration. Proceedings of the International 
Seabed Authority Workshop, 6-10 September 2004. International Seabed Authority, Kingston, Jamaica, 482 pp.

International Seabed Authority (2010) Regulations on prospecting and exploration for polymetallic sulphides in the Area. ISBA/16/A/12/Rev.1. International Seabed Authority, Kingston, Jamaica, 49 pp.

International Seabed Authority (2011) Environmental management of deep-sea chemosynthetic ecosystems: justification of and considerations for a spatially-based approach. ISA Technical Study Series, 9. International Seabed Authority, Kingston, Jamaica, $79 \mathrm{pp}$.

International Seabed Authority (2012) Environmental management needs for exploration and exploitation of deep sea minerals. ISA Technical Study Series, 10. International Seabed Authority, Kingston, Jamaica, $47 \mathrm{pp}$.

InterRidge (2009) InterRidge statement of commitment to responsible research practices at deep-sea hydrothermal vents [Online]. Available: http://www.interridge.org/IRStatement (accessed December 19th 2012).

Jones ML (1981) Riftia pachyptila Jones: Observations on the vestimentiferan worm from the Galápagos Rift. Science 213, 333-336.

Karl DM, Wirsen CO, Jannasch HW (1980) Deep-sea primary production at the Galápagos hydrothermal vents. Science 207, 1345-1347.

Kastner M, Craig H, Sturz A (1986) Hydrothermal deposition in the Mariana Trough: preliminary mineralogical investigation. Eos Transactions American Geophysical Union 68, 1531.

Kelly N, Metaxas A (2008) Diversity of invertebrate colonists on simple and complex substrates at hydrothermal vents on the Juan de Fuca Ridge. Aquatic Biology 3, 271281.

Kelly N, Metaxas A, Butterfield D (2007) Spatial and temporal patterns of colonization by deep-sea hydrothermal vent invertebrates on the Juan de Fuca Ridge, NE Pacific. Aquatic Biology 1, 1-16.

Kong L, Ryan WBF, Mayer LA, Detrick RS, Fox PJ, Manchester K (1985) Bare-rock drill sites, ODP Legs 106 and 109: Evidence for hydrothermal activity at $23^{\circ} \mathrm{N}$ on the MidAtlantic Ridge. Eos Transactions American Geophysical Union 66, 936.

Krasnov SG, Cherkashev GA, Stepanova TV, Batuyev BN, Krotov AG, Malin BV, Maslov MN, Markov VF, Poroshina IM, Samovarov MS, Ashadze AM, Lazareva LI, Ermolayev IK (1995) Detailed geological studies of hydrothermal fields in the North Atlantic. In: 
Parson LM, Walker CL, Dixon DR (eds.) Hydrothermal vents and processes, Vol 87. Geological Society of London, London, UK, pp 43-64.

Lonsdale PF, Bischoff JL, Burns VM, Kastner M, Sweeney RE (1980) A high-temperature hydrothermal deposit on the seabed at a Gulf of California Spreading Center. Earth and Planetary Science Letters 49, 8-20.

Lutz RA, Kennish MJ (1993) Ecology of deep-sea hydrothermal vent communities - a review. Reviews of Geophysics 31, 211-242.

Lutz RA, Shank TM, Fornari DJ, Haymon RM, Lilley MD, Vondamm KL, Desbruyères $D$ (1994) Rapid growth at deep-sea vents. Nature 371, 663-664.

Malahoff A (2008) Opportunities and challenges in polymetallic sulfide mining in the Kermadec Ridge and back arc basins. The 33rd International Geological Congress, 6 14th August 2008, Oslo, Norway.

Marsh AG, Mullineaux LS, Young CM, Manahan DT (2001) Larval dispersal potential of the tubeworm Riftia pachyptila at deep-sea hydrothermal vents. Nature 411, 77-80.

Marsh L, Copley JT, Huvenne VAI, Linse K, Reid WDK, Rogers AD, Sweeting CJ, Tyler PA (2012) Microdistribution of faunal assemblages at deep-sea hydrothermal vents in the Southern Ocean. Plos One 7, e48348.

Metaxas A (2004) Spatial and temporal patterns in larval supply at hydrothermal vents in the northeast Pacific Ocean. Limnology Oceanography 49, 1949-1956.

Metaxas A (2011) Spatial patterns of larval abundance at hydrothermal vents on seamounts: evidence for recruitment limitation. Marine Ecology Progress Series 437, 103-117.

Miljutin DM, Miljutina MA, Arbizu PM, Galeron J (2011) Deep-sea nematode assemblage has not recovered 26 years after experimental mining of polymetallic nodules (ClarionClipperton Fracture Zone, Tropical Eastern Pacific). Deep-Sea Research Part IOceanographic Research Papers 58, 885-897.

Mining Act 1992 and Regulation [Online]. Available: http://www.mra.gov.pg/Portals/2/Publications/MINING ACT\%201992.pdf $\quad$ (accessed March 15th 2013).

Ministry of Economic Development. Current permits NZ Petroleum and Minerals [Online]. Available: http://www.nzpam.govt.nz/cms/online-services/current-permits/ (accessed March 15th 2013).

Mironov AN, Gebruk AV, Mosjalev LI (1998) Biogeography patterns of the hydrothermal vent fields: a comparison with non-vent biogeography. Cahiers de Biologie Marine 39, 367-368. 
Moalic Y, Desbruyères D, Duarte CM, Rozenfeld AF, Bachraty C, Arnaud-Haond S (2012) Biogeography revisited with network theory: retracing the history of hydrothermal vent communities. Systematic Biology 61, 127-137.

Mottl MJ, Davis EE, Fisher AT, Slack JF (eds.) (1994) Proceedings of the Ocean Drilling Program, Scientific Results, Vol 139. College Station, Texas.

Mullineaux LS, Adams DK, Mills SW, Beaulieu SE (2010). Larvae from afar colonize deepsea hydrothermal vents after a catastrophic eruption. Proceedings of the National Academy of Sciences of the United States of America 107, 7829-7834.

Murton BJ, Van Dover CL, Southward E (1995) Geological setting and ecology of the Broken Spur hydrothermal vent field: 29 degree 10 minute $\mathrm{N}$ on the Mid-Atlantic Ridge. In: Parson LM, Walker CL, Dixon DR (eds.) Hydrothermal vents and processes, Vol 87. Geological Society of London, London, UK, pp 33-41.

Nautilus Minerals Inc. (2013) Nautilus Minerals Inc. home page [Online]. Available: http://www.nautilusminerals.com/s/Home.asp (accessed March 15th 2013).

Plüger WL, Herzig PM, Becker KP, Deissmann G, Schöps D, Lange J, Jenisch A, Ladage S, Richnow HH, Schulze T, Michaelis W (1990). Discovery of hydrothermal fields at the Central Indian Ridge. Marine Mining 9, 73-86.

Reisser CMO, Bell JJ, Wood AR, Gardner JPA (2011) Connectivity, small islands and large distances: The Cellana strigilis limpet complex in the Southern Ocean. Molecular Ecology 20, 3399-3413.

Reynolds KC, Watanabe H, Strong EE, Sasaki T, Uematsu K, Miyake H, Kojima S, Suzuki Y, Fujikura K, Kim S, Young CM (2010) New molluscan larval form: brooding and development in a hydrothermal vent gastropod, Ifremeria nautilei (Provannidae). Biological Bulletin 219, 7-11.

Rogers AD, Tyler PA, Connelly DP, Copley JT, James R, Larter RD, Linse K, Mills RA, Garabato AN, Pancost RD, Pearce DA, Polunin NV, German CR, Shank T, BoerschSupan PH, Alker BJ, Aquilina A, Bennett SA, Clarke A, Dinley RJ, Graham AG, Green DR, Hawkes JA, Hepburn L, Hilário A, Huvenne VA, Marsh L, Ramirez-Llodra E, Reid WD, Roterman CN, Sweeting CJ, Thatje S, Zwirglmaier K (2012) The discovery of new deep-sea hydrothermal vent communities in the Southern Ocean and implications for biogeography. Plos Biology 10, e1001234.

Rona PA (1985) Hydrothermal mineralization at slow-spreading centers: Red Sea, Atlantic Ocean and Indian Ocean. Marine Mining 5, 117-145.

Rona PA (2003) Resources of the sea floor. Science 299, 673-674. 
Rona PA, Klinkhammer G, Nelsen TA, Trefry JH, Elderfield H (1986) Black smokers, massive sulphides and vent biota at the Mid-Atlantic Ridge. Nature 321, 33-37.

Shank TM, Halanych KM (2007) Toward a mechanistic understanding of larval dispersal: insights from genomic fingerprinting of the deep-sea hydrothermal vent tubeworm Riftia pachyptila. Marine Ecology-an Evolutionary Perspective 28, 25-35.

Smith CR (1989) Vent fauna on whale remains. Nature 341, 27-28.

Spiess FN, Macdonald KC, Atwater T, Ballard R, Carranza A, Cordoba D, Cox C, Garcia VMD, Francheteau J, Guerrero J, Hawkins J, Haymon R, Hessler R, Juteau T, Kastner M, Larson R, Luyendyk B, Macdougall JD, Miller S, Normark W, Orcutt J, Rangin C (1980) East Pacific Rise: hot springs and geophysical experiments. Science 207, 14211433.

Stoffers P, Wright IC, de Ronde CEJ, Hannington MD, Vilinger H, Herzig P, Shipboard scientific party (1999) Little-studied Arc-Backarc system in the spotlight. Eos Transactions American Geophysical Union 80, 353-364.

Stöhr S, Segonzac M (2005) Deep-sea ophiuroids (Echinodermata) from reducing and non-reducing environments in the North Atlantic Ocean. Journal of the Marine Biological Association of the United Kingdom 85, 383-402.

Sudarikov SM, Galkin SV (1995) Geochemistry of the Snake Pit vent field and its implications for vent and non-vent fauna. In: Parson LM, Walker CL, Dixon DR (eds.) Hydrothermal vents and processes, Vol 87. Geological Society of London, London, UK, pp 319-327.

Thaler, AD, Zelnio, K, Saleu W, Schutltz TF, Carlsson J, Cunningham C, Vrijenhoek RC, Van Dover CL (2011) The spatial scale of genetic subdivision in populations of Ifremeria nautilei, a hydrothermal vent gastropod from the southwest Pacific. BMC Evolutionary Biology 11, 372.

Tolstoy M, Cowen JP, Baker ET, Fornari DJ, Rubin KH, Shank TM, Waldhauser F, Bohnenstiehl DR, Forsyth DW, Holmes RC, Love B, Perfit MR, Weekly RT, Soule SA, Glazer B (2006) A sea-floor spreading event captured by seismometers. Science 314, 1920-1922.

Tunnicliffe V (1997) Hydrothermal vents: a global system. In: Deep Sea Research in subduction zones, spreading centers and backarc basins, JAMSTEC Technical Reports, pp 105-114.

Tunnicliffe V, Embley RW, Holden JF, Butterfield DA, Massoth GJ, Juniper SK (1997) Biological colonization of new hydrothermal vents following an eruption on Juan de 
Fuca Ridge. Deep-Sea Research Part I-Oceanographic Research Papers 44, 16271644.

Tunnicliffe V, McArthur AG, McHugh D (1998) A biogeographical perspective of the deepsea hydrothermal vent fauna. In: Blaxter JHS, Southward AJ, Tyler PA (eds.) Advances in Marine Biology. Academic Press, Waltham, MA, pp 353-442.

Tyler PA, Paterson GJL, Sibuet M, Guille A, Murton BJ, Segonzac M (1995) A new genus of ophiuroid (Echinodermata: Ophiuroidea) from hydrothermal mounds along the MidAtlantic Ridge. Journal of the Marine Biological Association of the United Kingdom 75, 977-986.

Tyler PA, Young CMY (2003) Dispersal at hydrothermal vents: a summary of recent progress. Hydrobiologia 503, 9-19.

Underwood A (1991) Beyond BACl: Experimental designs for detecting human environmental impacts on temporal variations in natural populations. Marine and Freshwater Research 42, 569-587.

Underwood AJ (1992) Beyond BACl: the detection of environmental impacts on populations in the real, but variable, world. Journal of Experimental Marine Biology and Ecology 161, 145-178.

United Nations (2012) The Convention on Biological Diversity [Online]. Available:

http://www.cbd.int/doc/legal/cbd-en.pdf (accessed April 4th, 2013).

United Nations. Report of the World Summit on Sustainable Development [Online]. Available:

http://daccess-ddsny.un.org/doc/UNDOC/GEN/N02/636/93/PDF/N0263693.pdf?OpenElement (accessed April 4th, 2013).

United Nations. United Nations Convention on the Law of the Sea. [Online] Available: http://www.un.org/Depts/los/convention agreements/texts/unclos/unclos e.pdf (accessed April 4th, 2013).

United Nations Environment Programme. Declaration of the United Nations Conference on the Human Environment [Online]. Available:

http://www.unep.org/Documents.Multilingual/Default.asp?documentid=97\&articleid=150 $\underline{3}$ (accessed December 19th 2012).

United Nations Environment Programme. Rio Declaration on Environment and Development [Online]. Available: http://www.unep.org/documents. multilingual/default.asp?documentid=78\&articleid=116 $\underline{3}$ (accessed December 19th 2012). 
Van Dover CL (2000) The ecology of deep-sea hydrothermal vents. Princeton University Press, Princeton, NJ, 424 pp.

Van Dover CL (2007) The biological environment of polymetallic sulphides deposits, the potential impact of exploration and mining on this environment, and data required to establish environmental baselines in exploration areas. In: Polymetallic sulphides and cobalt-rich ferromanganese crusts deposits: establishment of environmental baselines and an associated monitoring programme during exploration. International Seabed Authority, Kingston, Jamaica, pp 169-190.

Van Dover CL (2011) Mining seafloor massive sulphides and biodiversity: what is at risk? ICES Journal of Marine Science 68, 341-348.

Van Dover CL, Aharon P, Bernhard JM, Caylor E, Doerries M, Flickinger W, Gilhooly W, Goffredi SK, Knick KE, Macko SA, Rapoport S, Raulfs EC, Ruppel C, Salerno JL, Seitz RD, Sen Gupta BK, Shank T, Turnipseed M, Vrijenhoek R (2003) Blake Ridge methane seeps: characterization of a soft-sediment, chemosynthetically based ecosystem. Deep-Sea Research Part I-Oceanographic Research Papers 50, 281-300.

Van Dover CL, German CR, Speer KG, Parson LM, Vrijenhoek RC (2002) Evolution and biogeography of deep-sea vent and seep invertebrates. Science 295, 1253-1257.

Van Dover CL, Hessler RR (1990) Spatial variation in faunal composition of hydrothermal vent communities on the East Pacific Rise and Galapagos Spreading Center. In: McMurray GR (ed.) Gorda Ridge: a seafloor spreading center in the United States' Exclusive Economic Zone. Springer New York, New York, NY, pp 253-264.

Van Dover CL, Smith CR, Ardron J, Dunn D, Gjerde K, Levin L, Smith S (2012) Designating networks of chemosynthetic ecosystem reserves in the deep sea. Marine Policy 36, 378-381.

VentBase 2012: Standardising ecological assessments for hydrothermal vent ecosystems [Online]. Available: http://www.ventbase.org/ (accessed March 15th 2013).

Von Damm KL (1990). Seafloor hydrothermal activity: black smoker chemistry and chimneys. Annual Review of Earth and Planetary Science 18, 173-204.

Vrijenhoek RC (1997) Gene flow and genetic diversity in naturally fragmented metapopulations of deep-sea hydrothermal vent animals. Journal of Heredity 88, 285293.

Wei K, Wood AR, Gardner JPA (2013) Population genetic variation in the New Zealand greenshell mussel: locus-dependent conflicting signals of weak structure and high gene flow balanced against pronounced structure and high self-recruitment. Marine Biology 160, 931-949. 
Williams A, Schlacher TA, Rowden AA, Althaus F, Clark MR, Bowden DA, Stewart R, Bax NJ, Consalvey M, Kloser RJ (2010) Seamount megabenthic assemblages fail to recover from trawling impacts. Marine Ecology 31, 183-199.

Wolff, T., 2005. Composition and endemism of the deep-sea hydrothermal vent fauna. Cahiers de Biologie Marine 46, 97-104.

Wright IC, de Ronde CEJ, Faure K, Gamble JA (1998) Discovery of hydrothermal sulfide mineralization from southern Kermadec Arc volcanoes (SW Pacific). Earth and Planetary Science Letters 164, 335-343.

Zierenberg RA, Fouquet Y, Miller DJ and leg 169 Shipboard scientific party (1996) The roots of seafloor sulphide deposits: preliminary results from ODP Leg 169 drilling in Middle Valley and Escanaba Trough. Eos American Geophysical Union Transactions $77,765$. 


\title{
CHAPTER 3. Megabenthic assemblage structure on three New Zealand seamounts: implications for seafloor massive sulfide mining
}

\begin{abstract}
Seamounts are recognized for their biological importance, and more recently, mineral wealth. However, in most cases the biological information required to assess the risk to seamount assemblages from mining is lacking. This study uses towed video footage and environmental data to investigate the patterns of megafaunal distribution, assemblage structure and association with environmental variables, both within and amongst three seamounts along the Kermadec volcanic arc in the New Zealand Exclusive Economic Zone. These seamounts represent different levels of hydrothermal activity with an overlapping depth range; Rumble II East has no history of hydrothermal activity, Brothers is hydrothermally active and Rumble II West is predominantly inactive. All three seamounts fall within an area previously licenced for the prospecting phase of seafloor massive sulfide (SMS) mining. In total, 186 putative taxa were identified from video samples and assigned to 20 assemblages. Both seamount and a priori defined habitat (nested within seamount) contributed to explaining variation in assemblage structure, with a mixture of shared and unique assemblages found at each seamount. Magnetivity, as proxy for hydrothermal activity, explained the majority of variation in assemblage structure amongst seamounts, with depth, topography, substratum (and magnetivity for Brothers) explaining the majority within seamounts. Environmental management implications include the need to designate a network of 'set-aside' sites both within and amongst seamounts to adequately protect the range of faunal assemblages present. This study also suggests inactive SMS areas may support faunal assemblages not found elsewhere within the region and would require suitable protection from mining activities.
\end{abstract}




\section{Introduction}

Seamounts have considerable biological value, as potential stepping stones for dispersal (Hubbs 1959, Wilson and Kaufmann 1987), oases of high faunal abundance and biomass (Rowden et al. 2010b) and hotspots of species richness (Samadi et al. 2006, Morato et al. 2010), although not all seamounts have these characteristics (see review by Rowden et al. 2010a).

Seamount assemblages vary at multiple spatial scales, from habitat patches within a single seamount to variation amongst seamounts in the same or in different regions (Clark et al. 2010). For example, at Horizon Guyot in the central North Pacific, aspects of the megafauna demonstrated random or patchy distribution at scales of $10-1000 \mathrm{~m}$ with strong correlation to hard substratum distribution (Kaufmann et al. 1989). The degree of habitat diversity within a seamount can also influence faunal diversity, as found in the Gulf of Alaska, where the seamount with the greatest diversity in habitat (topography and relief) was characterized by the highest relative faunal diversity (Raymore 1982). Seamount habitats and faunal communities are shaped by a suite of environmental variables including light levels, water column productivity and chemistry, hydrodynamic regime, seamount geomorphology, substratum type and hydrothermal activity (reviewed by Clark et al. 2010).

Seamounts are vulnerable to anthropogenic pressures such as fishing (Clark and Tittensor 2010) and, in the future, seabed mining (Halfar and Fujita 2007). Mineral resources at seamounts include cobalt-rich ferromanganese crust (also known as cobaltrich crust or polymetallic crust), and seafloor massive sulfide (SMS) deposits. Of these two deposit types, SMS is expected to be mined at a commercial scale in the western Pacific in the near future (Nautilus Minerals Inc.: home page at www.nautilusminerals). SMS deposits form through hydrothermal circulation to create areas of hard substratum rich in sulfides and base metals. There are currently 165 deposits known globally (Hannington et al. 2011), which occur across a range of hydrothermal settings, as reviewed by Boschen et al. (2013).

Hydrothermal activity has considerable influence on benthic assemblages inhabiting seamounts that host SMS deposits. Hydrothermally active areas are colonised by a chemosynthetic assemblage of hydrothermal vent specialists (reviewed by Van Dover 2000, 2014). Hydrothermal vent fauna are typified by high biomass and low diversity (Grassle 1985) and rapid growth rates (Lutz et al. 1994). Hydrothermally inactive areas are colonised by 'background' fauna typical of hard substrata on seamounts, such as the sponges, hydroids, corals, anemones, squat lobsters, ophiuroids and holothurians 
inhabiting inactive areas of the Manus Basin (Galkin 1997). Over a scale of 10s to $100 \mathrm{~s}$ of meters, chemosynthetic and background faunal assemblages exhibit zonation based on proximity to hydrothermal flow, with chemosynthetic assemblages existing in close proximity to hydrothermal flow, and background assemblages existing at the vent periphery (Arquit 1990, Sudarikov and Galkin 1995). It has also been hypothesised that a third assemblage may exist at SMS deposit sites, one specific to the unique chemical environment of weathering inactive SMS deposits (Van Dover 2007, 2011).

In order to assess the vulnerability of seamount benthic fauna to mining activities, it is important to describe the structure and evaluate the variability of benthic assemblages, both amongst and within seamounts. There are very few studies investigating seamount faunas associated with mineral deposits. At Cross Seamount in the Hawaiian Archipelago, cobalt-rich crust deposits were characterised by low diversity and low abundance of benthic megafauna (Grigg et al. 1987). A later study along the Hawaiian Seamount Chain found differences in benthic assemblage structure between seamounts located inside and outside the cobalt-rich crust region, driven by relative species composition and abundance, rather than species richness (Schlacher et al. 2014). The only study characterising benthic assemblages at delineated SMS deposits was conducted at a proposed mine and reference site in the Manus Basin, off Papua New Guinea. Here Collins et al. (2012) found three faunal assemblages in active areas, which were distinct from a 'peripheral assemblage' of Abyssocladia sponges, amphipods, stalked barnacles, squat lobsters, lepetodrilid limpets and thyasirid clams.

The main objective of the present study was to determine the broad scale spatial variability in benthic megafaunal structure within and amongst seamounts of commercial interest for their SMS deposits along the Kermadec Volcanic Arc, within the New Zealand Exclusive Economic Zone (EEZ). This included the objective to investigate the hypothesised existence of an assemblage specific to inactive SMS deposits (Van Dover 2007,2011 ). The study also aimed to identify the environmental variables associated with patterns in benthic assemblage structure. Assessing the variability in assemblage structure within and amongst seamounts, and in particular how SMS deposits contribute to assemblage structure in the region, will provide information essential to the environmental management of any future mining activities. 


\section{Materials and Methods}

\subsection{Study area}

Three seamounts were targeted for survey; Rumble II East, Brothers and Rumble II West (Fig. 1). These volcanoes were chosen to span a range of environments; Rumble II East is hydrothermally inactive with no SMS deposits, Brothers has large hydrothermally active areas where SMS deposits are forming, and Rumble II West is predominantly hydrothermally inactive with inactive SMS deposits. These seamounts are ideal for a comparative study because they lie within $0.5^{\circ}$ of latitude and have overlapping depth ranges (Rumble II East: 907 - 3017 m (Wright 1994); Brothers: 1350 - 2250 m (Wright and Gamble 1999); Rumble II West: 1194 - 2994 m (Wright 1994)). Both Brothers and Rumble II West have SMS deposits of potential interest to mining companies, with prospecting permits for both seamounts having been issued to Neptune Minerals in 2002 (Fig. 1, https://www.nzpam.govt.nz/cms/banner template/CMINPSCURR).

\subsection{Image data collection and analysis}

Photographic transect data (video and still images) were collected during Leg 2 of the TAN1007 cruise on R.V. Tangaroa between $29^{\text {th }}$ May and $11^{\text {th }}$ June in 2010. Imagery was obtained using the NIWA Deep-Towed Imaging System (DTIS) with a high definition digital video camera (Sony $1080 \mathrm{i}$ format) angled $45^{\circ}$ forwards and a vertically orientated still image camera (Canon EOS 400D $10 \mathrm{mp}$ ). The ship travelled at $0.5-1 \mathrm{kt}$ with the camera system being towed approximately $2-4 \mathrm{~m}$ above the seabed. A total of 51 transects over the 3 seamounts were of sufficient quality for analysis. Transects were distributed randomly amongst broad scale habitat strata (caldera floor, caldera wall, seamount cone, seamount flank, and chimney fields) defined a priori based on general topography from a multibeam survey undertaken during Leg 1 of the TAN1007 cruise on R.V. Tangaroa between $12^{\text {th }}$ and $29^{\text {th }}$ May in 2010 (Fig. 2). Transects were conducted to have as much overlap in depth range as possible between the same habitats on each seamount (Table 1). For analysis of the video (analysis of still images is not considered here), transects were divided into $200 \mathrm{~m}$ long contiguous samples (using GIS) to enable greater spatial resolution of faunal distribution data. Two of the $200 \mathrm{~m}$ samples (each with only one faunal observation along their length) were excluded for statistical analysis purposes, leaving a total of 249 video samples (Table 1). 
The video samples were analysed using the Ocean Floor Observation Protocol (OFOP) software (version 3.3.4a, Scientific Abyss Mapping Services, http://www.ofop-bysams.eu/). Syncing video footage and navigation files through OFOP enables users to generate automatically geo-referenced faunal observation files during footage playback. All fauna were identified to the best taxonomic resolution possible. Some fauna could be confidently identified to species level but the majority could only be identified to family level or higher. The faunal records obtained from video analysis were in the form of count data, which due to changes in altitude along transects and the continuous nature of recording observations in OFOP, could not be translated to a true abundance. Instead, the frequency of observations was used to give an indication of relative abundance. The faunal observations from OFOP files were matched to their respective $200 \mathrm{~m}$ sample using a script written in R (http://www.r-project.org/). Video samples where the camera altitude above the seabed was $<1.0 \mathrm{~m}$ or $>5.0 \mathrm{~m}$ were excluded to avoid bias in faunal observations resulting from camera altitude and consequent changes in image quality. The altimeter malfunctioned during one transect (station 33), so altimetry data were obtained by regression using the distance between the laser scaling dots on 101 still images from stations where altimetry was known. This regression was then applied to 128 images from station 33, to match the faunal observations in OFOP to their nearest altitude measurement as calculated from the images. Matched resemblance matrix tests (RELATE) in PRIMER 6 (Clarke and Gorley 2006) were used to assess whether the altitude within the range chosen for analysis and the percentage of excluded observations had an influence on the faunal distribution patterns observed. These pre-analysis tests revealed that neither altitude nor percentage of excluded observations had an influence that may be likely to confound the main analysis (i.e. the Rho values were very small; altitude $=0.087$, number of excluded observations $=0.002$ ). 


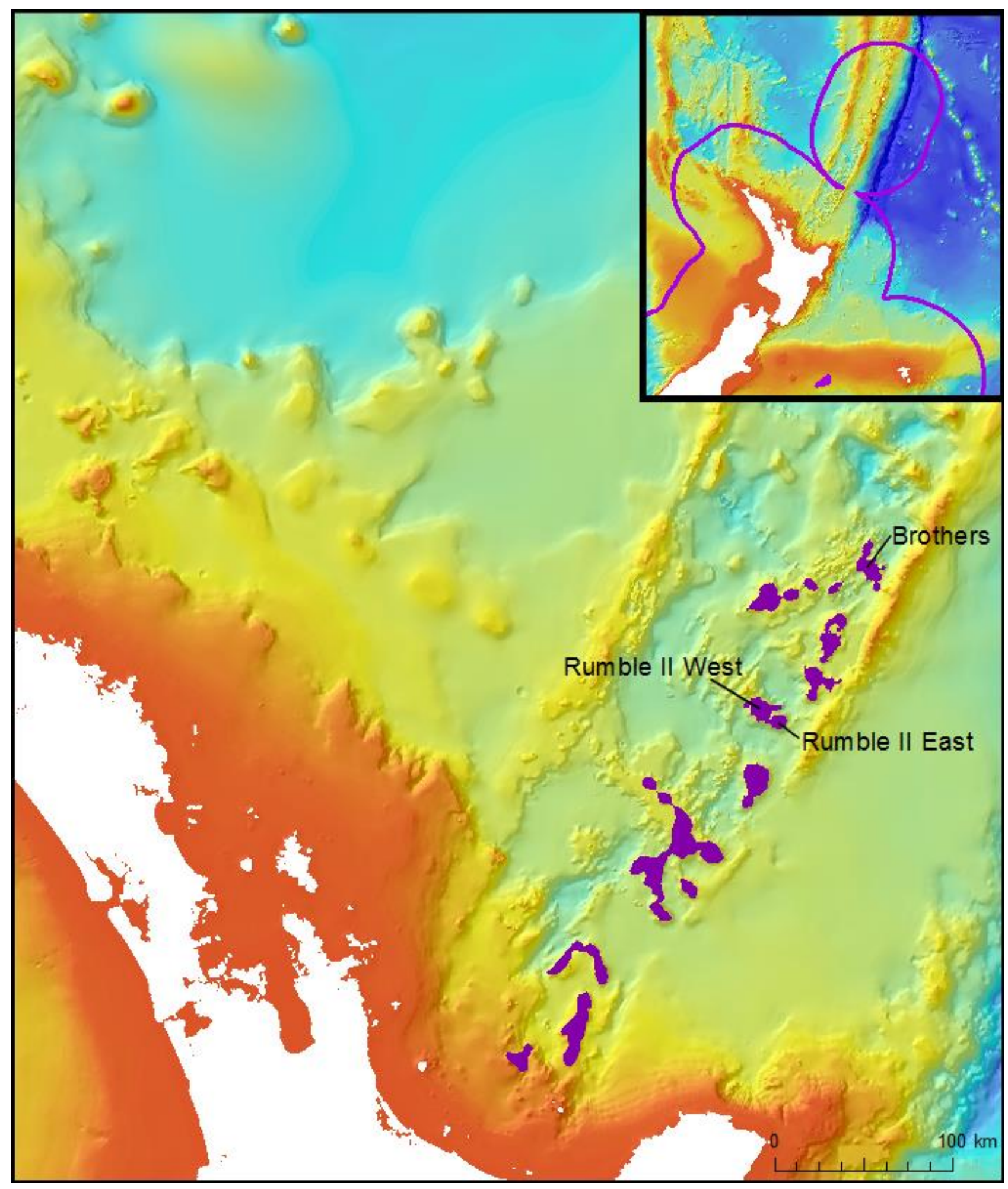

Figure 1. Location of the seamounts Rumble II East, Rumble II West and Brothers in relation to areas licenced for SMS prospecting (purple shading). Insert: regional context of study area including northern New Zealand mainland and Exclusive Economic Zone (purple line). 

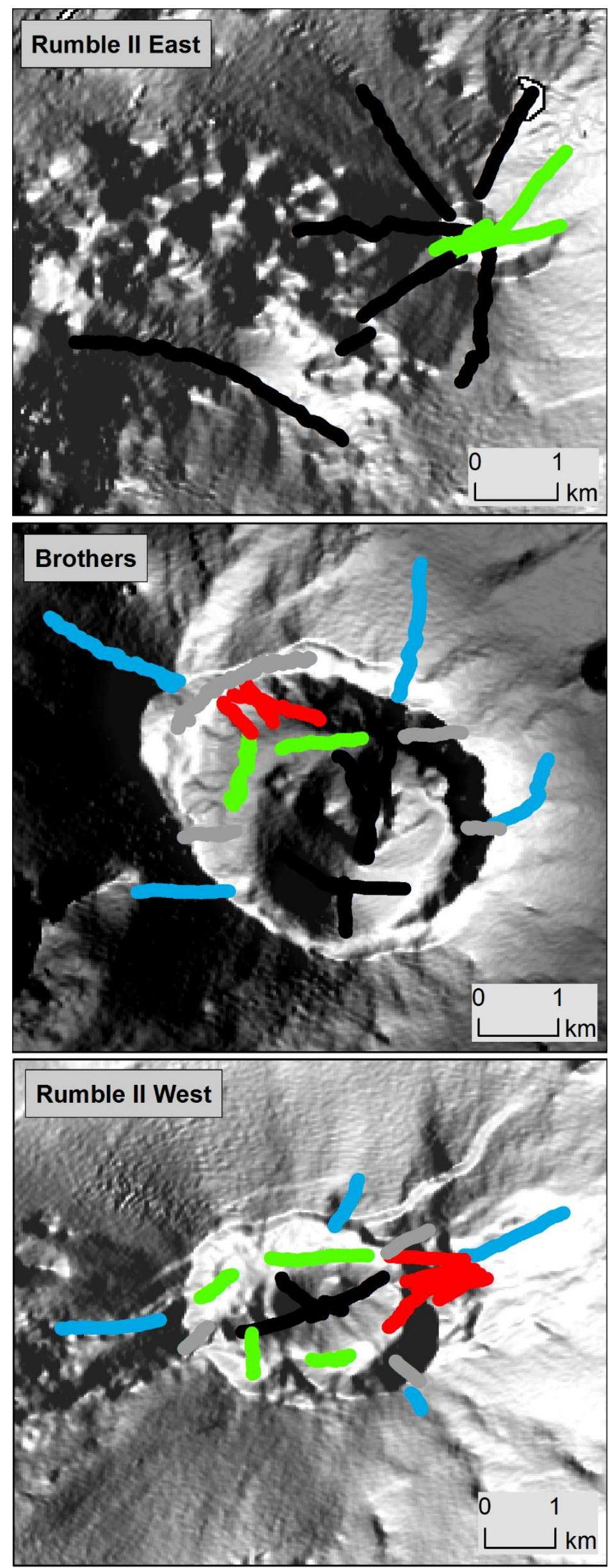

Caldera $\bullet$ Chimney $\bullet$ Cone $\bullet$ Flank $\bullet$ Wall
Figure 2. Distribution of towedcamera transects across the five $a$ priori defined habitat strata (caldera floor (caldera), chimney fields (chimney), seamount cone (cone), seamount flank (flank) and caldera wall (wall)) at the three study seamounts (Rumble II East, Brothers and Rumble II West). 
Table 1. Distribution of video transects and $200 \mathrm{~m}$ samples and their respective depth ranges, across the three seamounts and a priori defined habitat strata; Caldera (caldera floor), wall (caldera wall), cone (seamount cone), flank (seamount flank), and chimney (chimney fields).

\begin{tabular}{|l|l|l|l|l|}
\hline Seamount & Habitat substratum & Transects & $\begin{array}{l}\text { \# of 200 m } \\
\text { samples }\end{array}$ & Depth range (m) \\
\hline \multirow{2}{*}{$\begin{array}{l}\text { Rumble II } \\
\text { East }\end{array}$} & Cone & 8 & 59 & $940-2110$ \\
\cline { 2 - 5 } & Caldera & 4 & 17 & $1020-1400$ \\
\hline \multirow{5}{*}{ Brothers } & Cone & 5 & 22 & $1200-1730$ \\
\cline { 2 - 5 } & Flank & 5 & 30 & $1350-1960$ \\
\cline { 2 - 5 } & Caldera & 2 & 11 & $960-1880$ \\
\cline { 2 - 5 } & Wall & 4 & 22 & $1390-1700$ \\
\cline { 2 - 5 } & Chimney & 3 & 11 & $1530-1910$ \\
\hline \multirow{3}{*}{\begin{tabular}{l} 
Wumble II \\
\cline { 2 - 5 }
\end{tabular}} & Cone & 4 & 14 & $1160-1450$ \\
\cline { 2 - 5 } & Flank & 4 & 16 & $1340-1450$ \\
\cline { 2 - 5 } & Caldera & 4 & 6 & $1180-1460$ \\
\cline { 2 - 5 } & Wall & 3 & 23 & $940-2110$ \\
\cline { 2 - 5 } & Chimney & 5 & 249 & \\
\hline
\end{tabular}

\subsection{Environmental data}

Substratum type was described and identified from the video using OFOP. Substratum was described in a hierarchical fashion to include information on morphology/particle size class and potential chemical staining (Table 2). Substratum was quantified through semicontinuous recording with observations being made every few seconds.

Position information was obtained from the DTIS navigation file. Additional environmental data - depth, backscatter (acoustic reflectivity), rugosity, aspect, slope and three measures of curvature (curvature, plan curvature, profile curvature: used to describe the relative position of terrain features) - were extracted from multibeam data, collected using an EM300 multibeam echo-sounder (IMHO) and processed using C\&C Technologies HydroMap. Cleaned data were gridded to $25 \mathrm{~m}$ cell size resolution and exported to ESRI grid formats for use in ArcGIS. Backscatter data derived from multibeam were processed using SonarScope (Augustin and Lurton 2005). Processing consisted of statistical compensation of the signal as a function of its incidence angle on the seafloor, to attenuate the strong signal from specular reflection at nadir and the rapid decrease of the signal strength with increasing incidence angle (Hughes Clarke et al. 1997, Le Chenadec et al. 2007, Fonseca et al. 2009). Magnetivity data were collected at $500 \mathrm{~m}$ resolution over all three seamounts during TAN1007 using a Sea Spy Magnetics overhauser magnetometer, with data acquisition at $1 \mathrm{~Hz}$ using Marine Magnetics Sealink software. Magnetivity data were also obtained at $25 \mathrm{~m}$ resolution for Brothers Seamount (see Caratori Tontini et al. 2012a, 2012b). The mean and standard deviation for each of the 
multibeam-derived variables and magnetivity at both spatial scales were calculated for each $200 \mathrm{~m}$ video sample. This was achieved by splitting the $200 \mathrm{~m}$ DTIS line segments into points with $1 \mathrm{~m}$ spacing along track, and adding the grid cell value of all relevant layers as an attribute to the point layer. Mean and standard deviation for each relevant attribute value were than calculated for all points of one segment, generating a list of line segments and the mean and standard deviation for the underlying grid cell values. Means and standard deviations were calculated at different grid sizes (25 $\mathrm{m}$ and focal means 3, 5, 7 and 15) to enable environmental influences on assemblage structure to be investigated at the most appropriate spatial scale. Focal means consisted of $3 \times 3,5 \times 5,7 \times 7$ and $15 \times 15$ grid cells of the original $25 \mathrm{~m}$ grids.

Table 2. Hierarchy used to describe substrata, including information on morphology/particle size class and chemical (Iron and Sulfur) staining; '-' indicates no descriptor

\begin{tabular}{|c|c|c|}
\hline Sediment type & Sediment descriptor & Final class \\
\hline \multirow[t]{4}{*}{ Lava } & - & Lava \\
\hline & Iron & Lava iron \\
\hline & Sulfur & Lava sulfur \\
\hline & Vent & Lava vent \\
\hline \multirow[t]{3}{*}{ Chimney } & - & Chimney \\
\hline & Sulfur & Chimney sulfur \\
\hline & Vent & Chimney vent \\
\hline \multirow{3}{*}{ Boulders } & - & Boulders \\
\hline & Sulfur & Boulders sulfur \\
\hline & Vent & Boulders vent \\
\hline \multirow[t]{2}{*}{ Cobbles } & - & Cobbles \\
\hline & Sulfur & Cobbles sulfur \\
\hline \multirow[t]{3}{*}{ Pebbles } & - & Pebbles \\
\hline & Sulfur & Pebbles sulfur \\
\hline & Vent & Pebbles vent \\
\hline \multirow[t]{3}{*}{ Gravel } & - & Gravel \\
\hline & Sulfur & Gravel sulfur \\
\hline & Vent & Gravel vent \\
\hline \multirow[t]{2}{*}{ Sand } & - & Sand \\
\hline & Sulfur & Sand sulfur \\
\hline Muddy sediment & - & Muddy sediment \\
\hline Consolidated sediment & - & Consolidated sediment \\
\hline \multirow[t]{3}{*}{ Crust } & - & Crust \\
\hline & Iron & Crust iron \\
\hline & Vent & Crust vent \\
\hline
\end{tabular}




\subsection{Data analysis}

The faunal distribution data from the video samples were analysed using multivariate routines in the statistical software package PRIMER 6 (Clarke and Gorley 2006) with PERMANOVA+ (Anderson et al. 2008). Prior to analysis, count data were transformed. After trialling a range of transforms, square root transformation was used, as it downweighted the effect of abundant fauna sufficiently for the signal from rarer taxa to be observed, whilst still enabling the relative differences in abundance of taxa to influence the patterns in assemblage structure. A Bray-Curtis resemblance matrix was created from the transformed data. Hierarchical Cluster Analysis (CLUSTER) was performed on the resemblance matrix with a SIMPROF test (at $p=0.05$ ) to determine sample group structure in the faunal data, i.e. identify 'assemblages'. Multidimensional Scaling (MDS) plots were produced to visualise patterns in the grouping of samples associated with seamount, habitat and SIMPROF assemblage group. Similarity Percentages - species contributions (SIMPER) was performed on the transformed data to identify the taxa characterising each SIMPROF assemblage group (with a $50 \%$ cumulative cut off).

The spatial variability in the assemblage structure, both amongst and within seamounts, was described using Permutational MANOVA (PERMANOVA). Prior to PERMANOVA, the potential effect of multivariate dispersion was assessed using a Distance-based test for homogeneity of multivariate dispersions (PERMDISP), with 999 permutations. Deviations from centroid was chosen as the method giving the best overall results in terms of type I error and power (Anderson 2006). PERMDISP analyses suggested there was significant dispersion for both seamount $(F=6.9058$, df1 $=2$, df2 = 246, $p[$ perm $]=0.001)$ and habitat $(F=6.9012$, df1 $=4$, df2 $=244, p[$ perm $]=0.001)$ but as this dispersion occurred equally amongst different levels of the factors, it was not expected to affect the PERMANOVA results.

The effects of Seamount and Habitat nested within Seamount were assessed using PERMANOVA, with Type III (partial) sums of squares, permutations of residuals under mixed model and 999 permutations. Type III (partial) sums of squares was chosen as the most conservative model in which the order that terms are fitted is not important (Anderson et al. 2008). Permutation of residuals under a mixed model was selected as having the best power and being the most accurate regarding type I error (Anderson and Legendre 1999, Anderson and ter Braak 2003). 
The effect of environmental parameters on assemblage structure was assessed both amongst and within seamounts using Distance based linear models (DISTLM). Prior to DISTLM, draftsman plots and correlation matrices were produced to assess the distribution of each variable and to identify co-correlating variables. Where pairs of variables had a Pearson's correlation coefficient of 0.9 or larger, one of the co-correlating variables was excluded from the analysis (Anderson et al. 2008). If variables demonstrated skew within the draftsman plots, they were square root transformed to normalise their distribution. Initially, DISTLM was run with topographic variables at different grid sizes (25 $\mathrm{m}$, and focal means $3,5,7$ and 15) to assess which spatial scale best explained the assemblage structuring observed. Focal mean 15 (covering an area of $0.14 \mathrm{~km}^{2}$ ) had the highest $R^{2}$ value for both the grouped variable and ungrouped variable models and was chosen for all further analysis.

For the amongst-seamount analysis, the environmental variables were grouped according to data type; depth, topography (rugosity, curvature, plan-curvature, profilecurvature, slope), magnetivity, substratum (backscatter and all substratum types without obvious hydrothermal signatures), substratum hydrothermal (substratum with observed venting, sulfur or iron staining), habitat heterogeneity (the standard deviation of environmental variables), and 2D space (latitude and longitude). Space was ultimately excluded from the analysis to avoid autocorrelation issues. DISTLM was performed by grouping variables by indicator as described above, with selection based on the Akaike Information Criterion (AIC), step-wise selection procedure and 999 permutations. AIC selection was chosen as the method to create the most parsimonious model, as it adds a 'penalty' for increases in the number of the predictor variables (Anderson et al. 2008). Step-wise selection was chosen as it allows for both the addition and removal of a term to the model at each step (Anderson et al. 2008).

For the within-seamount analysis, DISTLM was first performed using the grouping of variables above, and then with the environmental variables ungrouped to investigate which individual variables were driving the observed patterns of environmental association with assemblage structure. For both of the above, DISTLM was performed using the same parameters as for the amongst-seamount analysis. Distance-based redundancy analysis ( $\mathrm{dbRDA}$ ) plots were used to provide the best possible 2D visualisation of DISTLM results for individual environmental variables at each of the three seamounts, with samples grouped by their SIMPROF assemblage and vectors proportional to their contribution to the total variation. 
Assemblages identified by SIMPROF were mapped, using ArcMap 10, over digital terrain models generated from multibeam data.

\section{Results}

\subsection{Assemblage structure}

In total, 186 putative taxa were identified from 249 video samples across the three seamounts. Cluster analysis indicated that the faunal records from the $200 \mathrm{~m}$ samples grouped both by seamount and by habitat within a seamount, which was visualised by MDS (Fig. 3A and B). PERMANOVA results indicated a significant influence of seamount $(\mathrm{df}=2, \mathrm{SS}=1.30 \mathrm{E} 5, \mathrm{MS}=65055$, Pseudo- $F=27.2, p[$ perm $]=0.001)$ and habitat nested within seamount $(\mathrm{df}=9, \mathrm{SS}=1.08 \mathrm{E}, \mathrm{MS}=12036$, Pseudo- $F=5.03, p[$ perm $]=0.001)$ on faunal distribution.

SIMPROF analysis identified 20 assemblages across the three seamounts, which were visualised by MDS (Fig. 3C). Six of these assemblages ( $d, f, j, l, q \& t)$ were shared amongst seamounts, whilst 14 assemblages were unique to individual seamounts (Fig. 4). Of the shared assemblages, four were found at all seamounts $(f, j, I \& t)$, one was shared between Rumble II East and Brothers ( $d$ ) and one was shared between Rumble II East and Rumble II West (q). Rumble II East had a total of 14 assemblages, eight of which were unique. Rumble II East assemblages required three to five taxa to make up $50 \%$ of the cumulative similarity between samples within an assemblage (Table 3). Brothers had eight assemblages, three of which were unique, with only one taxon required to make up $50 \%$ cumulative similarity within an assemblage (Table 3). Rumble II West had eight assemblages, three of which were unique, with between one and three taxa required to make up $50 \%$ cumulative similarity within an assemblage (Table 3 ). The spatial location of unique assemblages on Brothers $(a \& s)$ and Rumble II West $(b, k \& n)$ coincided with records of hydrothermal vent chimney structures (Fig. 4); chimneys were generally hydrothermally active on Brothers and inactive on Rumble II West. 


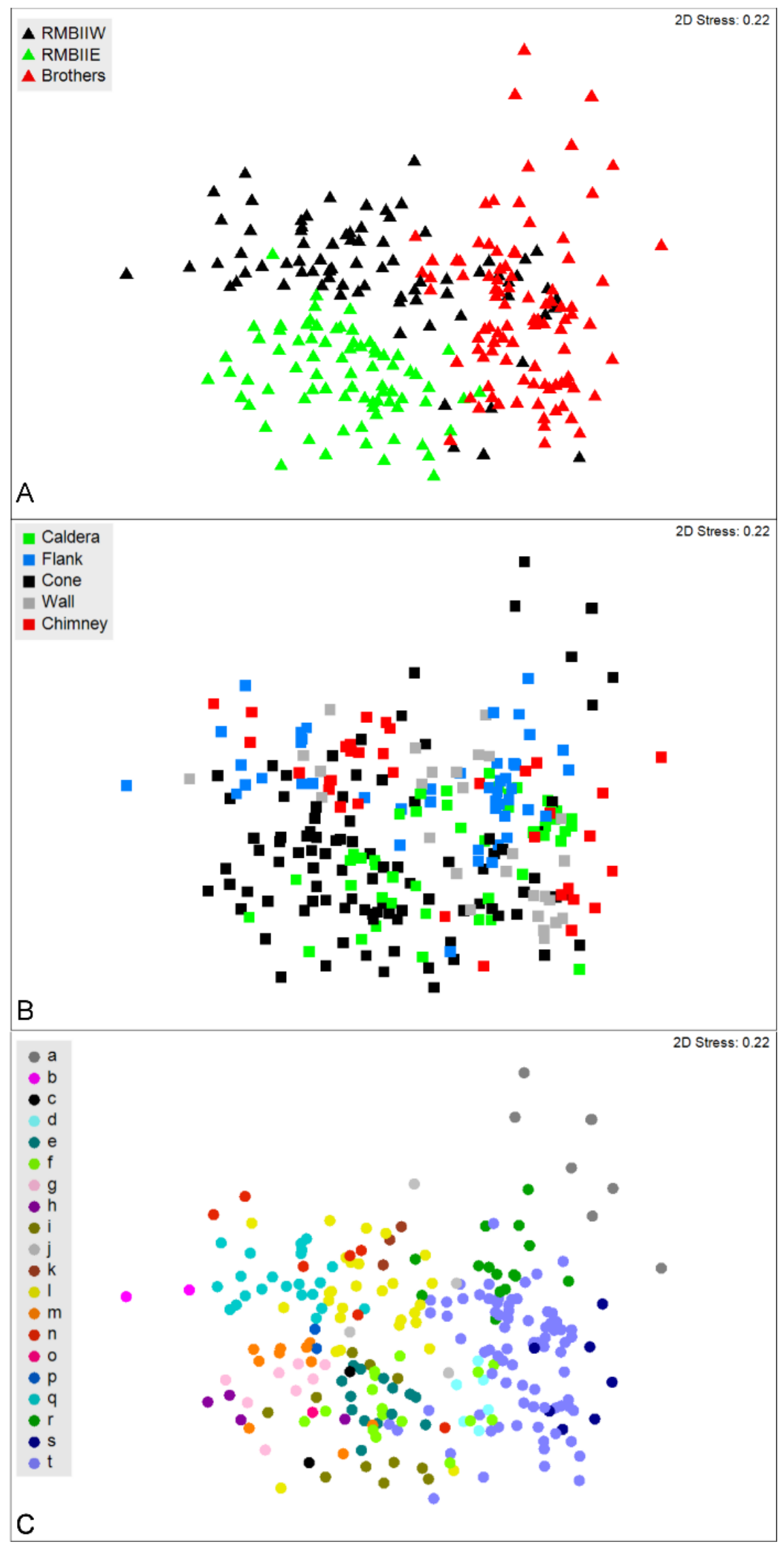

Figure 3.

Multi-dimensional Scaling (MDS) plot of $200 \mathrm{~m}$ video samples labelled by seamount (A: Rumble II West (RMBIIW), Rumble II East (RMBIIE) and Brothers), a priori defined habitat strata (B: caldera floor (caldera), seamount flank (flank), seamount cone (cone), caldera wall (wall) and chimney fields (chimney)) and SIMPROF assemblages (C: $a-t)$. 

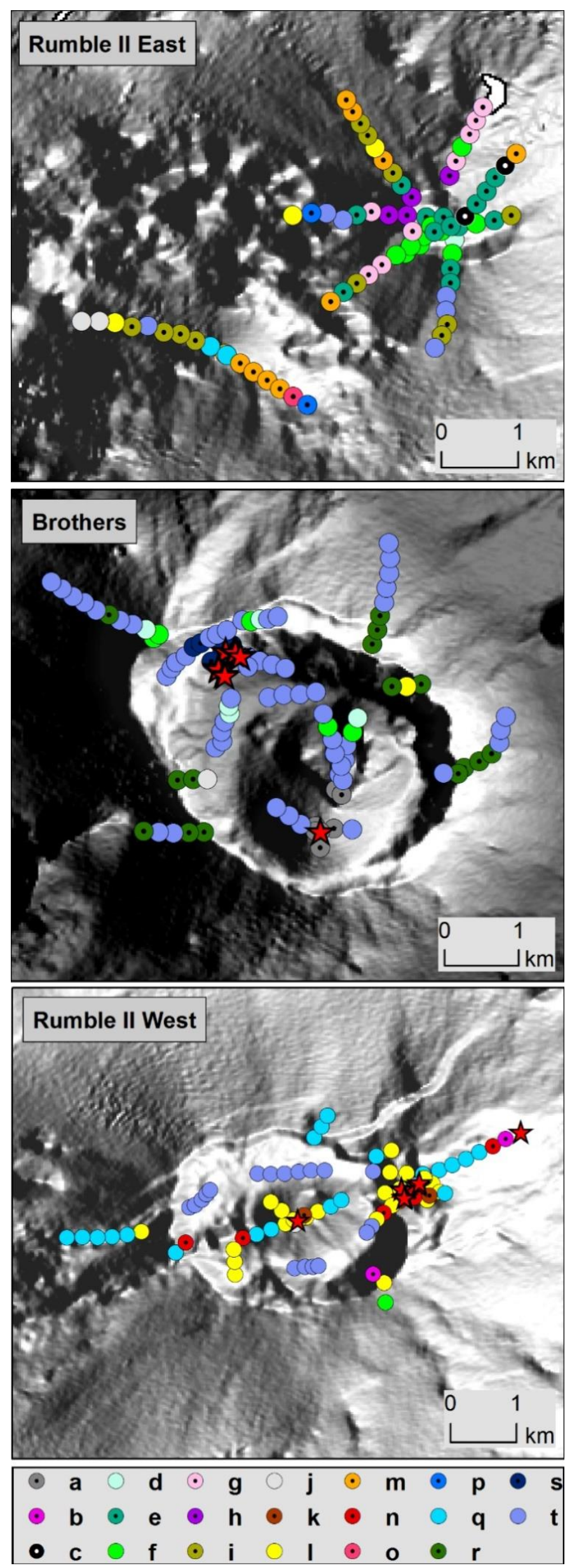

Figure 4. Digital terrain model maps of SIMPROF assemblage $(a-t)$ distribution over the three study seamounts. Symbols with a black centre indicate assemblages unique to one seamount. Red stars indicate the locations of hydrothermal vent chimney structures from video observations. 
Table 3. Taxa composition determined by SIMPER for the SIMPROF assemblages unique to each of the three seamounts; Rumble II East (RMBIIE), Brothers, and Rumble II West (RMBIIW), and shared between seamounts. For assemblages found at multiple seamounts, ashared between Rumble II East and Brothers, b found at all three seamounts, 'shared between Rumble II East and West. Group similarity indicates the percentage similarity between $200 \mathrm{~m}$ samples within the assemblage group. The cut off for cumulative percentage to the group similarity was $50 \%$. Group $o$ was unique to Rumble II East but only consisted of one $200 \mathrm{~m}$ sample and so could not be characterised by SIMPER analysis.

\begin{tabular}{|c|c|c|c|}
\hline Seamount & $\begin{array}{l}\text { Group: } \\
\text { similarity } \\
\%\end{array}$ & Taxa (contributing \%) & $\begin{array}{l}\text { Cumulative } \\
\%\end{array}$ \\
\hline \multirow[t]{7}{*}{ RMBIIE } & c: 32.44 & $\begin{array}{llll}\text { Actiniaria } 2 & (22.05), \quad \text { Ascidiacea } & 3 & \text { (15.59), } \\
\text { Farreidae/Euretidae 2 (15.59) } & & \\
\end{array}$ & 53.23 \\
\hline & e: 47.05 & $\begin{array}{l}\text { Xenophyophoroidea (27.68), } \\
\text { Hexactinellida } 4(11.49)\end{array}$ & 53.89 \\
\hline & $g: 43.61$ & $\begin{array}{l}\text { Xenophyophoroidea }(15.93) \text {, Hexactinellida } 4 \text { (13.98), } \\
\text { Farreidae/Euretidae } 2 \quad(10.13), \text { Stylasteridae (7.73), } \\
\text { Comatulida (7.30) }\end{array}$ & 55.12 \\
\hline & h: 47.04 & $\begin{array}{l}\text { Primnoidae/Isididae } 4 \text { (16.99), Rossella sp } 1 \text { (15.70), } \\
\text { Hexactinellida } 4 \text { (11.95), Xenophyophoroidea (9.26) }\end{array}$ & 53.89 \\
\hline & $i: 36.33$ & $\begin{array}{l}\text { Zoantharia-colonised stalk (16.81), Hydrozoa } 3 \text { (16.25), } \\
\text { Caridea (12.53), Hyalonema (Oonema) bipinnulum } \\
(10.26)\end{array}$ & 55.86 \\
\hline & $m: 45.40$ & Brachiopoda (41.98), Comatulida (7.75), Caridea (6.76) & 56.48 \\
\hline & $p: 48.09$ & $\begin{array}{l}\begin{array}{l}\text { Farreidae/Euretidae } 2 \\
\text { Caridea (15.27) }\end{array} \\
\text { (21.60), Comatulida (19.32), }\end{array}$ & 56.19 \\
\hline \multirow[t]{3}{*}{ Brothers } & a: 42.26 & Alvinocarididae/Hippolytidae (58.38) & 58.38 \\
\hline & $r: 58.40$ & Polychaeta (tubes) (66.56) & 66.56 \\
\hline & s: 59.96 & Echiura $2(66.16)$ & 66.16 \\
\hline \multirow[t]{3}{*}{ RMBIIW } & b: $\mathbf{3 3 . 9 0}$ & Comatulida (58.58) & 58.58 \\
\hline & $k: 42.90$ & Echiura (29.25) & 61.45 \\
\hline & $n: 32.71$ & $\begin{array}{l}\text { Scleractinia (branching) } \\
\text { Schizopathidae (9.88) }\end{array}$ & 58.16 \\
\hline \multirow{6}{*}{$\begin{array}{l}\text { Shared } \\
\text { between } \\
\text { seamounts }\end{array}$} & d: $54.86^{\mathrm{a}}$ & Xenophyophoroidea (51.18) & 51.18 \\
\hline & $f: 42.87^{b}$ & Xenophyophoroidea (61.56) & 61.56 \\
\hline & $j: 36.35^{b}$ & Ophiurida (74.95) & 74.95 \\
\hline & $l: 30.71^{b}$ & $\begin{array}{l}\text { Ophiurida (16.11), Caridea (14.91), Echiura } 1 \text { (8.62), } \\
\text { Comatulida (7.81), Xenophyophoroidea (6.98) }\end{array}$ & 54.42 \\
\hline & $q: 39.94^{c}$ & $\begin{array}{l}\text { Comatulida (20.35), Scleractinia (branching) (19.23), } \\
\text { Schizopathidae (7.84), Primnoidae/Isididae } 11 \text { (6.47) }\end{array}$ & 53.88 \\
\hline & $t: 34.37^{b}$ & Caridea $(56.65)$ & 56.65 \\
\hline
\end{tabular}




\subsection{Environmental drivers of assemblage structure}

The environmental drivers of differences in assemblage structure both amongst and within seamounts were identified using DISTLM. Amongst seamounts, the environmental variable groups included in the best model $\left(A I C=1958.7, R^{2}=0.32, R S S=5.62\right)$ were (in order of decreasing importance) magnetivity, depth, substratum, and topography (Table 4). Within seamounts, for Rumble II East the best model (AIC $=591.15, R^{2}=0.38, R S S=$ 1.22E 5) included depth, topography and substratum (Table 4.). The best DISTLM model for Brothers $\left(\mathrm{AIC}=732.16, \mathrm{R}^{2}=0.47, \mathrm{RSS}=1.33 \mathrm{E} 5\right.$ ) included topography, depth, substratum and magnetivity (Table 4). At Rumble II West, the best model (AIC $=604.41$, $R^{2}=0.43, R S S=1.30 E$ 5) selected substratum, depth and topography (Table 4). Substratum hydrothermal and habitat heterogeneity were not included in the best model for any of the analyses.

The contribution of individual environmental variables to the models was assessed by running a DISTLM where the variables were ungrouped (Table 5). At Rumble II East, there were 24 variables available, of which six were included in the best model (AIC = $588.36, R^{2}=0.26, R S S=1.46 E 5$ ). For Brothers, there were 41 environmental variables available, 12 of which were included in the best model $\left(\mathrm{AIC}=724.57, \mathrm{R}^{2}=0.44\right.$, RSS = 1.39E 5). Rumble II West had 31 environmental variables available, with 16 of these being included in the best model ( $\left.\mathrm{AIC}=599.47, \mathrm{R}^{2}=0.47, \mathrm{RSS}=1.22 \mathrm{E} 5\right)$. Depth was the only environmental variable to be included in the model for each of the three seamounts. The top three variables in terms of Pseudo- $F$ values were depth, lava and plan curvature at Rumble II East; depth, curvature and backscatter at Brothers; and boulders, depth and profile curvature at Rumble II West (Table 5). The importance of individual variable contribution to the models is visualised in the Distance-based redundancy analysis (dbRDA) plots (Fig. 5). 
Table 4. DISTLM Pseudo- $F$ values for the amongst-seamount (All) and within-seamount (RMBIIE, Brothers and RMBIIW) analyses. Displayed are the environmental variable groups selected by DISTLM as part of the best model, '-' indicates the group was available for the analysis but not selected as part of the best model.

\begin{tabular}{|l|l|l|l|l|}
\hline \multirow{2}{*}{$\begin{array}{l}\text { Environmental variable } \\
\text { group }\end{array}$} & \multicolumn{4}{|l|}{ Seamount Pseudo- $\boldsymbol{F}$ values } \\
\cline { 2 - 5 } & All & RMBIIE & Brothers & RMBIIW \\
\hline Topographic & 4.039 & 2.484 & 5.029 & 1.949 \\
\hline Depth & 6.882 & 6.935 & 3.745 & 2.231 \\
\hline Magnetivity & 15.967 & - & 2.374 & - \\
\hline Substratum & 5.421 & 1.859 & 2.542 & 3.508 \\
\hline Substratum hydrothermal & - & - & - & - \\
\hline Habitat heterogeneity & - & - & - & - \\
\hline
\end{tabular}

Table 5. DISTLM Pseudo- $F$ values for the within-seamount (RMBIIE, Brothers and RMBIIW) analysis when variables were made available to the model individually. Displayed are the environmental variable groups selected by DISTLM as part of the best models, '-' indicates the variable was available for the analysis but not selected as part of the best model. Co-correlates were variables that correlated with another variable at $R=0.9$ or greater and were subsequently excluded from the analyses. SD: standard deviation.

\begin{tabular}{|c|c|c|c|c|c|}
\hline \multirow{2}{*}{$\begin{array}{l}\text { Environmental } \\
\text { group }\end{array}$} & \multirow{2}{*}{$\begin{array}{l}\text { Environmental } \\
\text { variable }\end{array}$} & \multicolumn{3}{|c|}{ Seamount Pseudo- $F$ values } & \multirow{2}{*}{$\begin{array}{l}\text { Co-correlates } \\
{ }^{*} \mathrm{RMBIIE} \\
\text { ^RMBIIW }\end{array}$} \\
\hline & & RMBIIE & Brothers & RMBIIW & \\
\hline \multirow[t]{6}{*}{ Topography } & Plan curvature & 3.444 & - & 2.189 & Curvature $^{\star \wedge}$ \\
\hline & Profile curvature & 1.929 & - & 3.158 & Curvature ${ }^{\star \wedge}$ \\
\hline & Curvature & - & 7.114 & - & - \\
\hline & Aspect & - & 4.816 & 1.972 & - \\
\hline & Slope & - & 3.389 & 1.814 & SD depth^ \\
\hline & Rugosity & - & - & 1.905 & - \\
\hline Depth & Depth & 6.935 & 8.317 & 7.061 & - \\
\hline Magnetivity & Magnetivity $500 \mathrm{~m}$ & - & 3.889 & 1.830 & - \\
\hline \multirow[t]{6}{*}{ Substratum } & Lava & 5.574 & - & 1.986 & - \\
\hline & Crust & - & 4.323 & 1.680 & - \\
\hline & Boulders & - & - & 11.317 & - \\
\hline & Cobbles & - & - & 2.467 & - \\
\hline & Gravel & - & 3.465 & 2.283 & - \\
\hline & Backscatter & 2.351 & 6.138 & - & - \\
\hline \multirow{3}{*}{$\begin{array}{l}\text { Substratum } \\
\text { hydrothermal }\end{array}$} & Chimney vent & - & 4.008 & 1.831 & - \\
\hline & Chimney & - & - & 1.851 & - \\
\hline & Crust iron staining & - & - & 0.000 & - \\
\hline \multirow{2}{*}{$\begin{array}{l}\text { Habitat } \\
\text { heterogeneity }\end{array}$} & SD slope & 2.093 & 2.952 & - & - \\
\hline & SD magnetivity & - & - & 2.448 & - \\
\hline
\end{tabular}




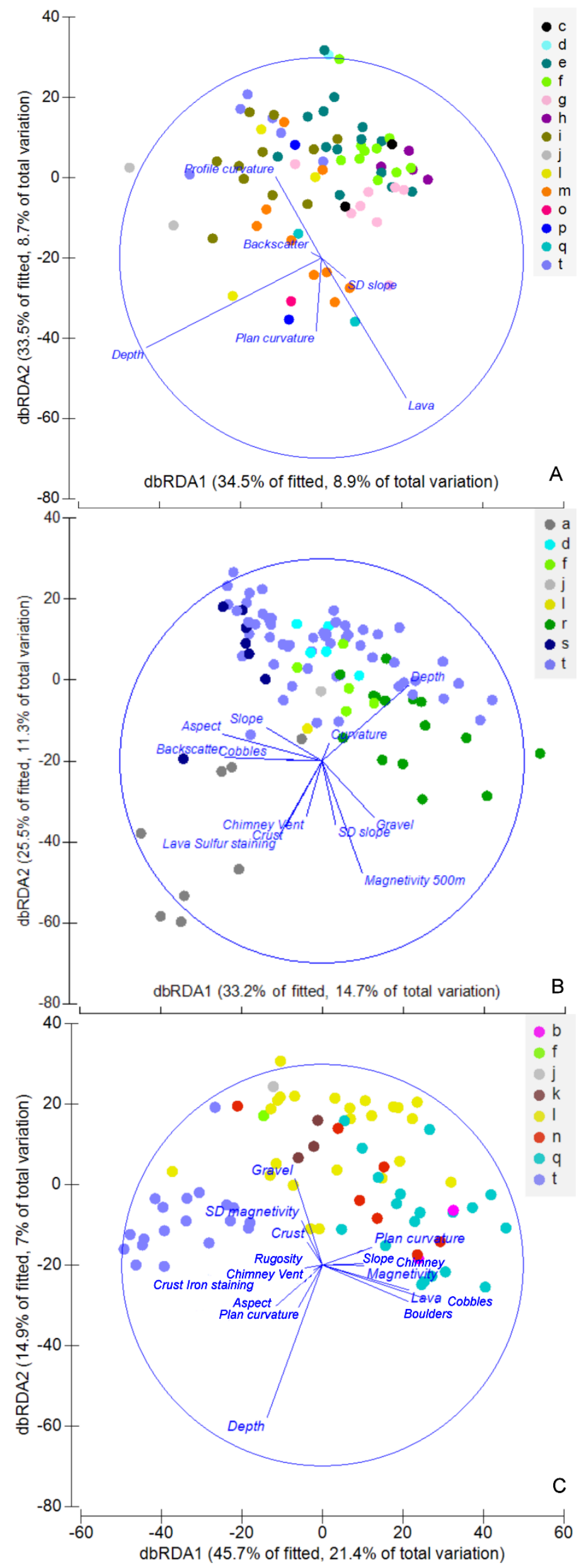

Figure 5. Distance-based redundancy analysis (dbRDA) plots to give the best possible visualisation of DISTLM results in 2D space for individual environmental variables at Rumble II East (A), Brothers (B) and Rumble II West (C). The coloured dots represent the samples grouped by SIMPROF assemblage. Vectors are proportional to their contribution to the total variation. 


\section{Discussion}

\subsection{Assemblage structure and environmental drivers amongst seamounts}

The seamounts selected for this study, Rumble II East, Brothers and Rumble II West, have different levels of hydrothermal activity and were expected to support different benthic assemblages. Analysis revealed that patterns in megabenthic assemblage structure differed both amongst seamounts and amongst habitats within seamounts. The patchwork of habitats observed at the studied seamounts also occurs elsewhere along the Kermadec Volcanic Arc at Rumble III and Rumble V seamounts, with highly variable species diversity and density within and amongst seamounts (Clark and O'Shea 2001, Rowden et al. 2003). Patchy faunal distribution is common at seamounts generally, such as at Cross and Jasper seamounts (Genin et al. 1986, Grigg et al. 1987) and Horizon Guyot (Kaufmann et al. 1989), where variability in the distribution of sessile filter feeders was associated with the occurrence of rocky prominences. These patterns reflect the variability of available habitats, where high between-habitat diversity supports high total seamount diversity (McClain et al. 2010).

The environmental drivers of assemblage structure amongst the three seamounts were magnetivity, depth, substratum and topography. Magnetivity can be a proxy for hydrothermal activity (Caratori Tontini et al. 2012a), with lower values occurring in regions of hydrothermal activity. The results of this study suggest that at the seamount scale, hydrothermal activity (either current or past) is the main driver of differences amongst the three seamounts. Substratum and depth were also important influences on benthic assemblage composition on the Lord Howe Rise, Australia (Anderson et al. 2011), whilst substratum is an important structuring factor at seamounts generally, such as for coral communities associated with the stable rocky outcrops of Lo'ihi seamount, Hawai'i (Grigg et al. 1997). As well as being a key factor in the present study, topography also influenced community structure at Patton Seamount in the Gulf of Alaska, with the greatest diversity in topography and relief being associated with the highest faunal diversity (Raymore 1982).

There were 6 assemblages shared amongst the seamounts $(d, f, j, l, q \& t)$. The protozoan xenophyophores dominating assemblages $d \& f$ were also common in patches of soft sediment on the Lord Howe Rise (Anderson et al. 2011), the summit of Horizon Guyot and Magellan Rise in the North Pacific (Kaufmann et al. 1989) and seamounts in the eastern Pacific off Mexico (Levin et al. 1986). The ophiuroids dominating assemblages $j \&$ I are typically dominant components of the deep-sea benthic fauna on both hard and soft substrata (O'Hara 2007) and are abundant at other seamounts, such as Admiralty 
Seamount in the Antarctic (Bowden et al. 2011). Assemblage $t$ was dominated by caridean shrimp and was especially prevalent at the two seamounts with current (Brothers) and relatively recent (Rumble II West) hydrothermal activity, which may suggest a vent association. A similar situation occurs at Kick'em Jenny volcano in the Caribbean, where shrimp with no record of vent association exist in large numbers within the crater, potentially trapped during their downward diel vertical migration and subsequently becoming opportunistic vent residents (Wishner et al. 2005). Assemblage $q$ was restricted to Rumble II East and West and was dominated by the long-lived and slow-growing filter feeders typically associated with seamount hard substratum; comatulid crinoids, branching stony coral, schizopathid corals and primnoid/isidid corals. Assemblage $q$ was not found on hydrothermally active Brothers, consistent with the findings of Clark and O'Shea (2001), who noted similar communities were almost entirely absent from hydrothermally active Rumble III and Rumble V seamounts. The absence of sessile filter feeding organisms was also noted at the volcanically and hydrothermally active peak of Northwest Rota-1 Volcano in the Mariana Arc (Limen et al. 2006) and has been attributed to environmental disturbance and the potentially "hostile" geochemical conditions of hydrothermal activity (Grigg 1997).

\subsection{Unique assemblage structure and the environment within seamounts}

The unique assemblages at Rumble II East ( $c, e, g, h, i, m \& p)$ were generally characterised by filter feeders, typical of communities associated with hard substratum on seamounts, such as ascidians, hexactinellid and stalked sponges, comatulid crinoids, brachiopods, stylasterids, primnoid/isidid corals and anemones. The occurrence of xenophyophores, with their preference for soft sediment, however also suggests a degree of habitat patchiness within some of the samples. The abundance of sessile filter feeding organisms at Rumble II East can be partially explained by the distribution of lava and plan curvature, which were in the model and in combination define the occurrence of continuous hard substratum (lava) as well as ridges and valleys to funnel the currents (plan curvature: Wilson et al. (2007)).

The unique assemblages at Brothers $(a, r \& s)$ had lower diversity, with each assemblage dominated by a single taxon; alvinocarid/hippolytid vent shrimp, tubed polychaete worms and echiuran worms respectively. The vent shrimp and echiuran worm assemblages occur within areas of hydrothermal activity, with their low diversity being typical of hydrothermal vent communities (Grassle 1985). The alvinocarid/hippolytid shrimp at Brothers are presumed to be reliant on chemosynthetic vent bacteria (Ahyong 2009), in 
a fashion similar to the closely related vent shrimp Rimicaris exoculata (Van Dover et al. 1988, Wirsen et al. 1993, Pond et al. 1997). Within the Southwest Pacific, alvinocarid shrimp also dominate hydrothermal communities on the active peak of Northwest Rota-1 Volcano (Limen et al. 2006), whilst Lebbeus hippolytid shrimp are exclusive to hydrothermally active sites, such as within the Manus and Lau Basins and the Okinawa Trough (Komai et al. 2012). The echiuran worms of assemblage $s$ are not considered to be vent endemic. However, large populations may have established themselves in vent sediments in response to high levels of organic matter and hydrogen sulfide, as echiuran worms have been observed to dominate organically enriched intertidal areas (Stull et al. 1986). The dominance of polychaete and echiuran worms can be partially explained by curvature and backscatter in the model. Curvature is important for describing the relative position of terrain features and inferring current flow (Wilson et al. 2007), whilst backscatter is affected by the substratum characteristics of the seabed. In combination, curvature and backscatter represent the current flow and nature of the seabed and will influence the feeding ability of tube-dwelling polychaetes and echiurans (filter feeders and surface deposit feeders respectively).

The unique assemblages at Rumble II West $(b, k \& n)$ exhibited relatively low diversity and high dominance, similar to the unique assemblages found at Brothers. Whilst assemblage $n$ had higher diversity (branching stony corals, caridean shrimp and schizopathid corals), $k$ and $b$ were dominated by one taxon, echiuran worms and comatulid crinoids respectively. Although Rumble II West is generally considered hydrothermally inactive, previous hydrothermal activity may have enriched the sediments enabling large populations of echiuran worms to establish, as observed at Brothers. The high abundance of crinoids at Rumble II West has also been observed on the hard substrate of other seamounts, such as Davidson and Pioneer off California (Lundsten et al. 2009) and Admiralty Seamount (Bowden et al. 2011). The abundance of crinoids and corals in certain unique Rumble II West assemblages can be partially explained by the factors of boulders and profile curvature in the model. Taken in combination, boulders and profile curvature identify elevated hard substratum, with higher current flow suitable for filter feeders. The occurrence of unique assemblages on Rumble II West coincided with video observations of hydrothermally inactive chimney structures, indicative of SMS areas. These chimneys provide elevated hard substratum and would be suitable habitat for filter feeders, as observed in the Manus Basin, where inactive chimneys are also colonised by sessile, filter feeding organisms, such as sponges, hydroids, corals, anemones, squat lobsters, ophiuroids and holothurians (Galkin 1997, Collins et al. 2012). 


\section{3 Implications for the management of seafloor massive sulfide mining}

The studied seamounts occur within areas originally licenced for SMS prospecting within the New Zealand EEZ. Prior to this study, little was reported on benthic assemblage structure at these seamounts, information essential for developing mitigation strategies for SMS mining.

The present study suggests considerable variability in habitat and biodiversity amongst seamounts. This is also the case when comparing seamounts of similar hydrothermal activity along the Kermadec Volcanic Arc; the alvinocarid/hippolytid shrimp observed on Brothers are absent from Rumble III, whilst the vent-endemic mussel Gigantidas gladius found at Rumble III and V is not present at Brothers (Clark and O'Shea 2001, Rowden et al. 2003). This has important implications for designing suitable strategies for mitigating the impact of mining activities on benthic fauna. One of these proposed strategies is the provision of 'set-aside' areas to preserve similar habitat and associated biodiversity within the region (International Seabed Authority 2010, Collins et al. 2013a, Collins et al. 2013b). The high variability in seamount assemblages implies that protecting one seamount to enable mining at an adjacent seamount may not be a suitable strategy. Instead, to conserve the suite of assemblages present, it may be necessary to protect multiple seamounts or a network of sites. As impacts for SMS mining are expected to be localised (e.g. the majority of sedimentation impacts should occur within $1 \mathrm{~km}$ of the mining site: Coffey Natural Systems (2008)), a network of smaller set-aside sites distributed within and amongst neighbouring seamounts may be a suitable strategy.

The unique assemblages at Rumble II West also suggests inactive SMS areas may support assemblages not found elsewhere in the region; individual taxa within these assemblages may be widely distributed but the grouping of taxa to form these assemblages appears to be unique. This provides some support for the hypothesis that the unique environment of weathered inactive SMS deposits could host specific fauna (Van Dover, 2007, 2011). The possibility of unique assemblages at inactive SMS deposits should be considered when designating set-aside sites, if they are to preserve local assemblage structure. 


\section{Acknowledgements}

We thank the crew and scientists aboard both legs of the TAN1007 cruise on R.V. Tangaroa. TAN1007 and the research reported here are part of the National Institute of Water and Atmospheric Research (NIWA) project 'Deep-sea mining of the Kermadec Arc Geophysical prospectivity and environmental impacts' funded by the New Zealand Ministry of Business, Innovation and Employment (formally the Foundation for Research Science and Technology) (contract CO1X0702). We thank Fabio Caratori Tontini (GNS Science) for providing the $25 \mathrm{~m}$ resolution backscatter data over Brothers and Vidette McGregor (NIWA) for assistance with the 'R' scripts. We also thank taxonomists at NIWA (Owen Anderson, Niki Davey, Michelle Kelly, Sadie Mills, Kate Neill, Geoff Read, Kareen Schnabel and Di Tracey) and the image analysis team (Dave Bowden, Caroline Chin, Rob Stewart, Peter Marriott and Alan Hart) for assistance. REB and SJB are supported by PhD scholarship funding from NIWA and Victoria University of Wellington. We are also grateful for the comments provided on this manuscript by three anonymous reviewers.

\section{References}

Ahyong S (2009) New species and new records of hydrothermal vent shrimps from New Zealand (Caridea: Alvinocarididae, Hippolytidae). Crustaceana 82, 775-794.

Anderson MJ (2006) Distance-based tests for homogeneity of multivariate dispersions. Biometrics 62, 245-253.

Anderson MJ, Gorley RN, Clarke KR (2008) PERMANOVA for PRIMER: Guide to software and statistical methods. PRIMER-E, Plymouth, UK, $214 \mathrm{pp}$.

Anderson MJ, Legendre P (1999) An empirical comparison of permutation methods for tests of partial regression coefficients in a linear model. Journal of Statistical Computation and Simulation 62, 271-303.

Anderson MJ, ter Braak CJF (2003) Permutation tests for multi-factorial analysis of variance. Journal of Statistical Computation and Simulation 73, 85-113.

Anderson TJ, Nichol SL, Syms C, Przeslawski R, Harris PT (2011) Deep-sea bio-physical variables as surrogates for biological assemblages, an example from the Lord Howe Rise. Deep-Sea Research Part II-Topical Studies in Oceanography 58, 979-991.

Arquit AM (1990) Geological and hydrothermal controls on the distribution of megafauna in Ashes vent field, Juan de Fuca Ridge. Journal of Geophysical Research: Solid Earth 95, 12947-12960. 
Augustin JM, Lurton X (2005) Image amplitude calibration and processing for seafloor mapping sonars. Oceans 2005 - Europe, 20-23 June 2005, Brest, France. Vol 1, pp 698-701.

Boschen RE, Rowden AA, Clark MR, Gardner JPA (2013) Mining of deep-sea seafloor massive sulfides: a review of the deposits, their benthic communities, impacts from mining, regulatory frameworks and management strategies. Ocean and Coastal Management 84, 54-67.

Bowden DA, Schiaparelli S, Clark MR, Rickard GJ (2011) A lost world? Archaic crinoiddominated assemblages on an Antarctic seamount. Deep-Sea Research Part II-Topical Studies in Oceanography 58, 119-127.

Caratori Tontini F, Davy B, de Ronde CEJ, Embley RW, Leybourne M, Tivey MA (2012a) Crustal magnetization of Brothers Volcano, New Zealand, measured by autonomous underwater vehicles: geophysical expression of a submarine hydrothermal system. Economic Geology 107, 1571-1581.

Caratori Tontini F, de Ronde CEJ, Yoerger D, Kinsey J, Tivey M (2012b) 3-d focused inversion of near-seafloor magnetic data with application to the Brothers Volcano hydrothermal system, southern Pacific Ocean, New Zealand. Journal of Geophysical Research: Solid Earth 117, B10102.

Clark MR, O'Shea S (2001) Hydrothermal vent and seamount fauna from the southern Kermadec Ridge, New Zealand. InterRidge News 10, 14-17.

Clark MR, Rowden AA, Schlacher T, Williams A. Consalvey M, Stocks KI, Rogers AD, O'Hara TD, White M, Shank TM, Hall-Spencer JM (2010) The ecology of seamounts: Structure, function, and human impacts. Annual Review of Marine Science 2, 253-278.

Clark MR, Tittensor DP (2010) An index to assess the risk to stony corals from bottom trawling on seamounts. Marine Ecology 31, 200-211.

Clarke KR, Gorley RN (2006) PRIMER v6: User manual/tutorial. PRIMER-E, Plymouth, UK, $190 \mathrm{pp}$.

Coffey Natural Systems (2008) Environmental Impact Statement, Solwara 1 project, Nautilus Minerals Niugini limited, Main Report, Vol A. Coffey Natural Systems, Brisbane, Australia, $222 \mathrm{pp}$.

Collins PC, Croot P, Carlsson C, Colaço A, Grehan A, Hyeong K, Kennedy R, Mohn C, Smith S, Yamamoto H, Rowden AA (2013a) A primer for the Environmental Impact Assessment of mining at seafloor massive sulfide deposits. Marine Policy 42, 198-209.

Collins PC, Kennedy R, Copley JT, Boschen RE, Forde J, Se-Jong J, Lindsay D, Marsh L, Nye V, Patterson A, Watanabe H, Yamamoto H, Carlsson J, Thaler AD (2013b) 
VentBase: developing a consensus among stakeholders in the deep-sea regarding Environmental Impact Assessment for deep-sea mining - a workshop report. Marine Policy 42, 334-336.

Collins PC, Kennedy R, Van Dover CL (2012) A biological survey method applied to seafloor massive sulphides (SMS) with contagiously distributed hydrothermal-vent fauna. Marine Ecology Progress Series 452, 89-107.

Fonseca L, Brown C, Calder B, Mayer L, Rzhanov Y (2009) Angular range analysis of acoustic themes from Stanton Banks Ireland: a link between visual interpretation and multibeam echosounder angular signatures. Applied Acoustics 70, 1298-1304.

Galkin SV (1997) Megafauna associated with hydrothermal vents in the Manus Back-Arc Basin (Bismarck Sea). Marine Geology 142, 197-206.

Genin A, Dayton PK, Lonsdale PF, Spiess FN (1986) Corals on seamount peaks provide evidence of current acceleration over deep-sea topography. Nature 322, 59-61.

Grassle JF (1985) Hydrothermal vent animals: distribution and biology. Science 229, 713717.

Grigg RW (1997) Benthic communities on Lo'ihi submarine volcano reflect highdisturbance environment. Pacific Science 51, 209-220.

Grigg RW, Malaboff A, Chave EH, Landahl J (1987) Seamount benthic ecology and potential environmental impact from manganese crust mining in Hawaii. In: Keating $\mathrm{BH}$, Fryer P, Batiza R, Boehlert GW (eds.) Seamounts, islands, and atolls, Geophysical Monograph Series 43. American Geophysical Union, Washington, DC, pp 379-390.

Halfar J, Fujita RM (2007) Danger of deep-sea mining. Science 316, 987.

Hannington M, Jamieson J, Monecke T, Petersen S, Beaulieu S (2011) The abundance of seafloor massive sulfide deposits. Geology 39, 1155-1158.

Hubbs CL (1959) Initial discoveries of fish faunas on seamounts and offshore banks in the eastern Pacific. Pacific Science 13, 311-316.

Hughes Clarke JE, Danforth BW, Valentine P (1997) Areal seabed classification using backscatter angular response at $95 \mathrm{khz}$. High Frequency Acoustics in Shallow Water, 30 June - 4 July, 1997, Lerici, Italy.

International Seabed Authority (2010) Regulations on prospecting and exploration for polymetallic sulphides in the Area. ISBA/16/A/12/Rev.1. International Seabed Authority, Kingston, Jamaica, 49 pp.

Kaufmann RS, Wakefield WW, Genin A (1989) Distribution of epibenthic megafauna and lebensspuren on two central North Pacific seamounts. Deep-Sea Research 36, 18631896. 
Komai T, Tsuchida S, Segonzac M (2012) Records of species of the hippolytid genus Lebbeus White, 1847 (Crustacea: Decapoda: Caridea) from hydrothermal vents in the Pacific ocean, with descriptions of three new species. Zootaxa 3241, 35-63.

Le Chenadec G, Boucher J-M, Lurton X (2007) Angular dependence of k-distributed sonar data. IEEE Transactions on Geoscience and Remote Sensing 45, 1224-1235.

Levin LA, Demaster DJ, McCann LD, Thomas CL (1986) Effects of giant protozoans (class Xenophyophorea) on deep-seamount benthos. Marine Ecology Progress Series 29, 99104.

Limen H, Juniper SK, Tunnicliffe V, Clement M (2006) Benthic community structure on two peaks of an erupting seamount: Northwest Rota-1 Volcano, Mariana Arc, western Pacific. Cahiers de Biologie Marine 47, 457-463.

Lundsten L, Barry JP, Cailliet GM, Clague DA, DeVogelaere AP, Geller JB (2009) Benthic invertebrate communities on three seamounts off southern and central California, USA. Marine Ecology Progress Series 374, 23-32.

Lutz RA, Shank TM, Fornari DJ, Haymon RM, Lilley MD, Vondamm KL, Desbruyères D (1994) Rapid growth at deep-sea vents. Nature 371, 663-664.

McClain CR, Lundsten L, Barry J, DeVogelaere A (2010) Assemblage structure, but not diversity or density, change with depth on a northeast Pacific seamount. Marine Ecology an Evolutionary Perspective 31, 14-25.

Morato T, Hoyle SD, Allain V, Nicol SJ (2010) Seamounts are hotspots of pelagic biodiversity in the open ocean. Proceedings of the National Academy of Sciences of the United States of America 107, 9707-9711.

Nautilus Minerals Inc. (2014) Nautilus Minerals Inc. home page [Online]. Available: http://www.nautilusminerals.com/s/Home.asp (accessed November 27th 2014).

O'Hara TD (2007) Seamounts: centres of endemism or species richness for ophiuroids? Global Ecology and Biogeography 16, 720-732.

Pond DW, Dixon DR, Bell MV, Fallick AE, Sargent JR (1997) Occurrence of 16:2(n-4) and 18:2(n-4) fatty acids in the lipids of the hydrothermal vent shrimps Rimicaris exoculata and Alvinocaris markensis: nutritional and trophic implications. Marine Ecology Progress Series 156, 167-174.

Raymore PAJ (1982) Photographic investigations on three seamounts in the Gulf of Alaska. Pacific Science 36, 15-34.

Rowden AA, Clark MR, O'Shea S, Mcknight DG (2003) Benthic biodiversity of seamounts on the southern Kermadec Volcanic Arc. Marine Biodiversity Biosecurity Report 3, 
National Institute of Water and Atmospheric Research, Wellington, New Zealand, 23 pp.

Rowden AA, Dower JF, Schlacher TA, Consalvey M, Clark MR (2010a) Paradigms in seamount ecology: fact, fiction and future. Marine Ecology an Evolutionary Perspective 31, 226-241.

Rowden AA, Schlacher TA, Williams A, Clark MR and others (2010b) A test of the seamount oasis hypothesis: seamounts support higher epibenthic megafaunal biomass than adjacent slopes. Marine Ecology 31, 95-106.

Samadi S, Bottan L, Macpherson E, De Forges BR, Boisselier M-C (2006) Seamount endemism questioned by the geographic distribution and population genetic structure of marine invertebrates. Marine Biology 149, 1463-1475.

Schlacher TA, Baco AR, Rowden AA, O'Hara TD, Clark MR, Kelley C, Dower JF (2014) Seamount benthos in a cobalt-rich crust region of the central Pacific: conservation challenges for future seabed mining. Diversity and Distributions 20, 491-502.

Stull JK, Haydock Cl, Montagne DE (1986) Effects of Listriolobus pelodes (Echiura) on coastal shelf benthic communities and sediments modified by a major California wastewater discharge. Estuarine and Coastal Shelf Science 22, 1-17.

Sudarikov SM, Galkin SV (1995) Geochemistry of the Snake Pit vent field and its implications for vent and non-vent fauna. In: Parson LM, Walker CL, Dixon DR (eds.) Hydrothermal vents and processes, Vol 87. Geological Society of London, London, UK, pp 319-327.

Van Dover CL (2000) The ecology of deep-sea hydrothermal vents. Princeton University Press, Princeton, NJ, $424 \mathrm{pp}$.

Van Dover CL (2007) The biological environment of polymetallic sulphides deposits, the potential impact of exploration and mining on this environment, and data required to establish environmental baselines in exploration areas. In: Polymetallic sulphides and cobalt-rich ferromanganese crusts deposits: establishment of environmental baselines and an associated monitoring programme during exploration. International Seabed Authority, Kingston, Jamaica, pp 169-190.

Van Dover CL (2011) Mining seafloor massive sulphides and biodiversity: what is at risk? ICES Journal of Marine Science 68, 341-348.

Van Dover CL (2014) Impacts of anthropogenic disturbances at deep-sea hydrothermal vent ecosystems: a review. Marine Environmental Research 102, 59-72. 
Van Dover CL, Fry B, Grassle JM, Haumphris S, Rona PA (1988) Feeding biology of the shrimp Rimicaris exoculata at hydrothermal vents on the Mid-Atlantic Ridge. Marine Biology 98, 209-216.

Wessel P, Sandwell DT, Kim S-S (2010) The global seamount census. Oceanography 23, 24-33.

Wilson MFJ, O'Connell B, Brown C, Guinan JC, Grehan AJ (2007) Multiscale terrain analysis of multibeam bathymetry data for habitat mapping on the continental slope. Marine Geology 30, 3-35.

Wilson RR, Kaufmann RS (1987) Seamount biota and biogeography. In: Keating BH, Fryer P, Batiza R, Boehlert GW (eds.) Seamounts, islands and atolls, Geophysical Monograph Series 43. American Geophysical Union, Washington, DC, pp 355-377.

Wirsen CO, Jannasch HW, Molyneaux SJ (1993) Chemosynthetic microbial activity at MidAtlantic Ridge hydrothermal vent sites. Journal of Geophysical Research: Solid Earth 98, 9693-9703.

Wishner KF, Graff JR, Martin JW, Carey S, Sigurdsson H, Seibel BA (2005) Are midwater shrimp trapped in the craters of submarine volcanoes by hydrothermal venting? DeepSea Research Part I-Oceanographic Research Papers 52, 1528-1535.

Wright IC (1994) Nature and tectonic setting of the southern Kermadec submarine arc volcanoes: an overview. Marine Geology 118, 217-236.

Wright IC, Gamble JA (1999) Southern Kermadec submarine caldera arc volcanoes (SW Pacific): caldera formation by effusive and pyroclastic eruption. Marine Geology 161, 207-227. 


\title{
CHAPTER 4. Seafloor massive sulfide deposits support unique megafaunal assemblages: implications for seabed mining and conservation
}

\begin{abstract}
Mining of seafloor massive sulfides (SMS) is imminent, but the ecology of assemblages at SMS deposits is poorly known. Proposed conservation strategies include protected areas to preserve biodiversity at risk from mining impacts. Determining site suitability requires biological characterisation of the mine site and protected area(s). Video survey of a proposed mine site and protected area off New Zealand revealed unique megafaunal assemblages at the mine site. Significant relationships were identified between assemblage structure and environmental conditions, including hydrothermal features. Unique assemblages occurred at both active and inactive chimneys and are particularly at risk from mining-related impacts. The occurrence of unique assemblages at the mine site suggests that the proposed protected area is insufficient alone and should instead form part of a network. These results provide support for including hydrothermally active and inactive features within networks of protected areas and emphasise the need for quantitative survey data of proposed sites.
\end{abstract}




\section{Introduction}

Increasing anthropogenic pressure on terrestrial, fresh-water and marine ecosystems has resulted in the need for improved conservation measures, including the provision of suitable protected areas (Linke et al. 2011, Geldmann et al. 2013). This need is reflected in the Convention on Biological Diversity (CBD) which calls for signatory countries to conserve $17 \%$ of terrestrial and inland water, and $10 \%$ of coastal and marine areas by 2020 through "ecologically representative and well connected systems of protected areas and other effective area-based conservation measures" (United Nations Environment Programme 2011). However, established protected areas globally only cover approximately $13 \%$ of terrestrial and $3 \%$ of marine habitats (Watson et al. 2014). The majority of marine protected areas have been established in coastal areas and provide benefits such as preserving species and habitats, acting as controls to study fishing effects and as source sites for genetic diversity and recruitment to neighbouring fisheries (Costello 2014, Green et al. 2014). However, there is also a need to establish protected areas in the deep sea, which is exposed to anthropogenic pressures including disposal of rubbish, dumping of chemical and radioactive waste, extraction of oil and gas, and other extractive activities such as fishing and deep-sea mining (Ramirez-Llodra et al. 2011).

One of the deep-sea resources to be mined is seafloor massive sulfides (SMS), with exploitation expected to occur in the southwest Pacific before 2020 (Baker and Beaudoin 2013). SMS deposits form through hydrothermal activity. Hot acidic water filters up through the seabed and, as it cools, releases dissolved minerals that can accumulate to form chimney and mound structures on the seafloor. There are 165 recorded SMS deposits worldwide (Hannington et al. 2011), existing across a range of tectonic environments (Boschen et al. 2013). These deposits are rich in base metals, such as iron, copper, zinc and lead (Krasnov et al. 1995), which often occur at a mineral grade comparable to deposits on land (Hannington et al. 2011).

Five contracts for SMS exploration have been issued by the International Seabed Authority in international waters on the South West Indian Ridge, Central Indian Ridge and the Mid Atlantic Ridge (https://www.isa.org.jm/deep-seabed-minerals-contractors?atcontractors tabs alt=1). In the Western Pacific, Neptune Minerals Inc. holds tenements in the Exclusive Economic Zones of seven countries - Japan, Papua New Guinea, Solomon Islands, Vanuatu, Fiji, Tonga and New Zealand. These tenements cover approximately $175000 \mathrm{~km}^{2}$ of prospecting licence applications and granted prospecting licences (http://www.neptuneminerals.com/ourbusiness/tenements/). 
Alongside their mineral wealth, SMS deposits also provide a variety of benthic habitats that support different biological communities. These habitats include hydrothermally active areas, often with chimneys and vents; hydrothermally inactive areas with relict chimney structures; and non-hydrothermal hard substrata such as lava flows and bedrock. Active areas support a hydrothermal vent community that is reliant on hydrothermal activity to survive and cannot exist away from active vents (Van Dover 2000). Vent communities typically have a small number of species that occur in large numbers (Grassle 1985), with rapid growth rates of individuals enabling them to mature quickly and colonise new vent habitat (Lutz et al. 1994). Both inactive SMS areas and nonhydrothermal hard substrata are colonised by a peripheral community, typically consisting of background species that occur on hard substrata elsewhere within the deep sea (Galkin 1997, Collins et al. 2012). This fauna can develop large populations in close proximity to active vents by utilising the additional food sources, such as bacterial mat dislodged from the vents (Erickson et al. 2009). It has also been suggested that a third community, one consisting of specialised fauna adapted to the weathered sulphide environment, may exist at inactive SMS deposits (Van Dover 2011). However, there are a limited number of studies of inactive SMS deposits and only one has identified faunal assemblages that appear to be unique to inactive SMS areas (Boschen et al. 2015).

All communities inhabiting SMS deposits and the surrounding seabed are potentially at risk from mining activities. Although vent communities undergo natural habitat loss through changes in hydrothermal or volcanic activity (Lutz et al. 1994, Tunnicliffe et al. 1997), perturbation from mining could be an additional stressor, introducing the problem of cumulative negative impacts (Van Dover 2011). SMS mining is expected to remove the majority of fauna from the immediate area (Van Dover 2011, 2014), with additional impacts, such as habitat removal, altered hydrothermal flow and smothering with suspended sediment (Coffey Natural Systems 2008, Van Dover 2011, Boschen et al. 2013, Van Dover 2014). Many vent species are endemic to a particular region, and so habitat loss poses a serious risk to the persistence of certain vent fauna. The fauna found in the peripheral and inactive communities is typically composed of sessile, slow-growing suspension feeders (Galkin 1997, Collins et al. 2012, Boschen et al. 2015) and may take decades to recover from disturbance, if they are able to recover at all (Van Dover 2011, Boschen et al. 2013).

Within the New Zealand region, SMS deposits occur in the northern section of the New Zealand Exclusive Economic Zone (EEZ). These deposits are rich in silver and gold (de Ronde et al. 2011) and prospecting licences were issued for multiple areas along the 
Kermadec Volcanic Arc to Neptune Minerals Inc. in 2002 (https://permits.nzpam.govt.nz/aca/). Hydrothermal communities along the Kermadec Volcanic Arc include species endemic to the region, such as the vent mussels Gigantidas gladius and Vulcanidas insolatus (Von Cosel and Marshall 2003, 2010) and the vent shrimps Alvinocaris alexander and Lebbeus wera (Ahyong 2009). There is also preliminary evidence for unique assemblages of fauna that occur in regions of inactive SMS deposits (Boschen et al. 2015). However, the large video samples (200 m length) used by Boschen et al. (2015) may not have adequately accommodated the patchiness of SMS deposits, complicating the attempt to establish clear linkages between unique assemblages and inactive SMS habitat.

One of the proposed mitigation strategies for SMS mining is to preserve at-risk habitats and communities through the provision of protected areas, which is a wellestablished concept in both terrestrial and marine conservation (Pressey and Botrill 2009, Partnership for Interdisciplinary Studies of Coastal Oceans 2007). In waters beyond national jurisdiction, protected areas include "preservation reference zones", defined as "areas in which no mining shall occur to ensure representative and stable biota of the seabed in order to assess any changes in the biodiversity of the marine environment" (International Seabed Authority 2010). Such areas, also known as "set-aside sites" and "Reference Sites", should have similar physical and biological characteristics to the mine site and should be located so as not to be impacted by mining activities (Coffey Natural Systems 2008, Collins et al. 2013). These sorts of recommendations are sound in principle but have had limited field testing to date, with only one previous study on the practical applications of Reference Sites for SMS mining (Collins et al. 2012).

As part of an initial survey of the Kermadec Volcanic Arc SMS deposits, Neptune Minerals Inc. identified a potential mine site, termed "Proteus 1", and a Reference Site on Rumble II West Seamount (Fig. 1). The survey report suggested there could be differences between the seabed communities at these sites, however this was based on limited shipboard real-time observations (Beaumont and Rowden 2011). The key objective of the present study was to determine the structure of megafaunal assemblages at both sites, their linkages with environmental variables and ultimately to assess whether the Reference Site would be a suitable protected area for the proposed mine site of Proteus 1. An additional aim was to investigate the possible existence of assemblages unique to inactive SMS areas and if they exist, to evaluate the conservation management implications. 


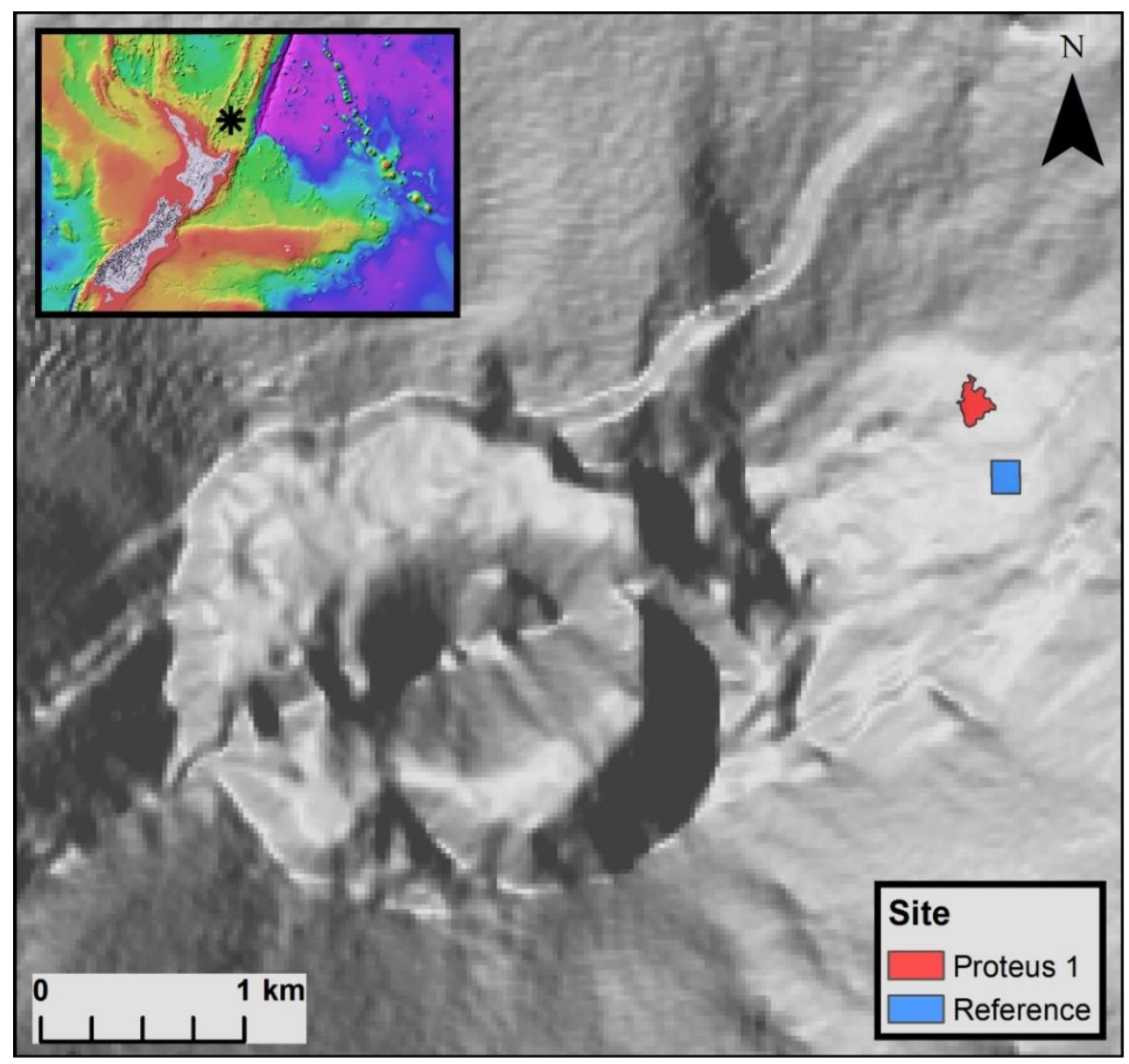

Figure 1. Location of study sites, Proteus 1 and the Reference Site, on a digital terrain model of Rumble II West Seamount. Inset: Location of Rumble II West on the Kermadec Volcanic Arc, as indicated by the star. The Arc is represented by the parallel raised areas of bathymetry (in orange) that stretch northeast from New Zealand towards Tonga.

\section{Materials and Methods}

\subsection{Study area}

Two sites were targeted for survey; a previously identified SMS deposit, Proteus 1, and a Reference Site. Both sites are located on the north-eastern flank of Rumble II West Seamount on the Kermadec Volcanic Arc (Fig. 1). The deposit was selected for its commercial interest, with a ship-based multibeam survey by Neptune Minerals Inc. identifying numerous hydrothermal chimney structures, indicative of SMS areas. At the time of the survey, Rumble II West Seamount was considered to contain relict SMS deposits, with no active hydrothermal areas. The Reference Site, covering a similar area, was selected to be similar to the deposit in terms of depth and topography based on preliminary visual interpretation of the multibeam-derived bathymetry at sea. The SMS deposit and Reference Site are $200 \mathrm{~m}$ apart to limit the potential effect of faunal changes with geographic distance. 


\subsection{Image data collection and analysis}

Photographic transect data (predominantly video footage) were collected during an industry survey by Neptune Minerals Inc. aboard RV Dorado Discovery between 1st March and 11th May 2011 (Beaumont and Rowden 2011). Imagery was obtained using the Remotely Operated Vehicle (ROV) Zeus II, operated by Odyssey Marine Exploration. The ROV was equipped with a high definition video camera and a stills camera, although as the latter was only operational for the first four dives, analyses were conducted solely using video footage. The video camera had a pan and tilt mechanism and an adjustable lighting system, but there was no laser scale available for any of the imagery. The ROV was piloted to fly approximately $1-6 \mathrm{~m}$ above the seabed for the video survey with frequent stops for geological sample collection. A total of six dives was completed over Proteus 1 and the Reference Site.

For analysis of the video, ROV tracks were divided into $15 \mathrm{~m}$ long segments (using ArcMap 10.3) to enable fine-scale spatial resolution of faunal distribution data. A range of video segment lengths was trialled $(10,15,20$ and $25 \mathrm{~m}$ ) to determine the segment length that achieved the best compromise between obtaining high spatial resolution and retaining informative assemblage structure data. Visual assessment of MDS plots (see Data analysis section) from each spatial scale confirmed $15 \mathrm{~m}$ to be the most appropriate segment length (Fig. S1 - S8). On occasion, ROV tracks overlapped both within and between dives, resulting in the potential for duplicate faunal records. To address this problem in areas of high overlap, observations from different dives were combined and 'new' tracks were created following the original tracks as closely as possible. This procedure allowed for a greater number of $15 \mathrm{~m}$ segments to be incorporated into the analysis whilst removing the issue of duplicate observational records at the same position.

The video segments were analysed using Ocean Floor Observation Protocol (OFOP) software (version 3.3.5, Scientific Abyss Mapping Services, http://www.ofop-bysams.eu/). Synchronising video footage and navigation files through OFOP enables users to generate automatically geo-referenced faunal observation files during footage playback. All megafauna were identified to the highest taxonomic resolution possible, based on the list of putative taxa used by Boschen et al. (2015). Some fauna could be confidently identified to species level but the majority could only be identified to family level or higher. The faunal records obtained from video analysis were in the form of count data, which due to 1) changes in ROV altitude along transects, 2) the lack of laser scaling, and 3) the continuous nature of recording observations in OFOP, could not be translated to true abundance. Instead, the frequency of observations was used to give an indication of 
relative abundance. The faunal observations from OFOP files were plotted in ArcMap 10.3, and all observations that occurred along each $15 \mathrm{~m}$ segment were extracted. Only those sections of video transect where the seabed could be seen clearly were used for analysis, i.e. all sections where the seabed was obscured (due to poor lighting, suspended sediment or high altitude) were not used.

\subsection{Environmental data}

Substratum type was identified from the video by geologists during the ROV survey. A hierarchical classification was then applied to these records (Table 1) to include information on substratum morphology/size class and potential hydrothermal influence, and to make records consistent between dives. The reclassified substratum observations were plotted in ArcMap 10.3 and extracted along the $15 \mathrm{~m}$ segments used for faunal analysis. Position files used for the dive tracks (and $15 \mathrm{~m}$ segments) were smoothed and splined to remove spikes in position data, whereas substratum observations made by shipboard geologists had positions relating to the raw track files. This situation meant substratum observations did not always fall directly along the $15 \mathrm{~m}$ segments, so a $2 \mathrm{~m}$ radius was used to extract the substratum observations relating to each $15 \mathrm{~m}$ segment. Dead coral and dead vent mussel shell records were made from analysing the footage in OFOP in the form of semi-continuous count data, providing an indication of the relative abundance of the remains of these taxa as biogenic substrata.

Position information was obtained from the ROV navigation file. Additional environmental data - depth, as well as topographic variables such as rugosity, aspect, slope and curvature - were extracted from the multibeam data that were collected using an ROV-mounted Reson SeaBat $7125200 \mathrm{KHz}$ multibeam echosounder and processed using Reson PDS2000 V3.6.0.16 software. Three measures of seabed curvature (curvature, plan curvature, profile curvature) were used as each provides different information on the relative shape of terrain features. The 'profile curvature' of a surface affects the acceleration and deceleration of flow, 'plan curvature' affects the convergence and divergence of flow, whilst 'curvature' is calculated as a combination of the two separate measures. By considering the measures of curvature separately it is possible to gain a greater insight into the flow across a surface (Kimmerling et al. 2011). Processed data were gridded to $1 \mathrm{~m}$ cell size resolution and exported to ESRI grid formats for use in ArcGIS. Backscatter data, used to compare the relative hardness of substrata, were collected at $25 \mathrm{~m}$ resolution using the ship-mounted Reson SeaBat $816050 \mathrm{KHz}$ multibeam echo-sounder. The mean and standard deviation for each of the multibeam- 
derived variables at both spatial scales were calculated for each $15 \mathrm{~m}$ video segment. These measures were achieved by splitting the $15 \mathrm{~m}$ segments into points with $0.15 \mathrm{~m}$ spacing along each track, and adding the grid cell value of all relevant layers as an attribute to the point layer. The mean and standard deviation for each relevant attribute value were then calculated for all points of one segment. Means and standard deviations were calculated at different grid sizes. For the ROV-mounted multibeam-derived variables, curvature, plan curvature and profile curvature were only available at native resolution (1 $\mathrm{m}$ grid size). Depth and slope were available at $1 \mathrm{~m}$ and grid focal means of 3, 5, 7 and 15 (i.e., $3 \times 3,5 \times 5,7 \times 7$ and $15 \times 15$ grid cells of the original $1 \mathrm{~m}$ grids). Rugosity could only be calculated at grid focal means of 3 and 5 . The ship-mounted multibeam-derived measure of backscatter was only calculated at $25 \mathrm{~m}$ grid size. Calculating the means and standard deviations at multiple grid sizes enabled the environmental influences on assemblage structure to be investigated at the most appropriate spatial scale. Aspect was ultimately transformed into "northness" and "eastness" using the cosine and sine respectively of the aspect values.

Table 1. Substratum hierarchical classification developed from the geological observations to include information on consolidation, broad type, physical and chemical properties. Dead coral and dead vent mussel shells were added to the classification from additional observation in OFOP; '-' indicates no descriptor.

\begin{tabular}{|l|l|l|l|l|}
\hline $\begin{array}{l}\text { Consolidated/ } \\
\text { unconsolidated }\end{array}$ & Type & $\begin{array}{l}\text { Physical } \\
\text { modifier }\end{array}$ & $\begin{array}{l}\text { Chemical } \\
\text { modifier }\end{array}$ & Final substratum type \\
\hline Consolidated & Volcaniclastic rock & - & - & Volcaniclastic rock \\
\hline Consolidated & Lava flow & - & - & Lava flow \\
\hline Consolidated & Lava flow & Lobate/pillow & - & Lava flow lobate/pillow \\
\hline Consolidated & Lava flow & - & Oxide & Lava flow oxide \\
\hline Consolidated & Breccia & - & Altered & Breccia altered \\
\hline Consolidated & Breccia & - & Oxide & Breccia oxide \\
\hline Consolidated & Crust & - & Oxide & Crust oxide \\
\hline Consolidated & Chimney & - & Inactive & Chimney inactive \\
\hline Consolidated & Chimney & - & Active & Chimney active \\
\hline Consolidated & Mound & - & Inactive & Mound inactive \\
\hline Unconsolidated & Mound & - & Active & Mound active \\
\hline Unconsolidated & Talus & - & - & Talus \\
\hline Unconsolidated & Talus & Pebble & - & Talus pebble \\
\hline Unconsolidated & Talus & - & Oxide & Talus oxide \\
\hline Unconsolidated & Sediment & - & - & Sediment \\
\hline Unconsolidated & Sediment & - & Altered & Sediment altered \\
\hline Biogenic & Dead coral & - & - & Dead coral \\
\hline Biogenic & Dead mussel shells & - & - & Dead mussel shells \\
\hline
\end{tabular}




\subsection{Data analysis}

The faunal distribution data from the video samples were analysed using multivariate routines in the statistical software package PRIMER 6 (Clarke and Gorley 2006) with PERMANOVA+ (Anderson et al. 2008). Prior to analysis, count data were transformed. After trialling a range of transformations, square root was used, as it down-weighted the effect of abundant fauna sufficiently for the signal from rarer taxa to be observed, whilst still enabling the relative differences in abundance of taxa to influence the patterns in assemblage structure. The $15 \mathrm{~m}$ length of video samples meant there were some samples with no fauna observed; 26 of the 116 segments at Proteus 1 (22\%) and five of the 37 segments at the Reference Site (14\%) were characterised by megafaunal absence. To deal with this issue statistically, a 'dummy variable' of $n=1$ was introduced, enabling a zero-adjusted Bray-Curtis resemblance matrix to be created from the transformed data (Clarke et al. 2006). Hierarchical Cluster Analysis (CLUSTER) was performed on the resemblance matrix with a SIMPROF test (at $p=0.05$ ) to determine sample group structure in the faunal data, i.e. to identify 'assemblages'. Non-metric Multidimensional Scaling (MDS) plots were produced to visualise patterns in the grouping of samples associated with site and SIMPROF assemblage group. The spatial distributions of assemblages were mapped, using ArcMap 10.3, over digital terrain models generated from multibeam data. The Similarity Percentages (SIMPER) routine was used on transformed data to identify the taxa characterising each SIMPROF assemblage group (with a 99.9\% cumulative cut-off).

The spatial variability in the assemblage structure between sites was described using permutational multivariate analysis of variance (PERMANOVA). Prior to PERMANOVA, the potential effect of multivariate dispersion was assessed using a distance-based test for homogeneity of multivariate dispersions (PERMDISP), with 999 permutations. Deviations from centroid was chosen as the method giving the best overall results in terms of Type I error and power (Anderson 2006). Because PERMDISP analyses did not reveal any significant dispersion for the factor 'Site' $(F=1.284$, df1 = 1 , $\mathrm{df2}=151, \mathrm{p}[$ perm $]=0.312)$ PERMANOVA was employed. The effect of Site on assemblage structure was assessed using PERMANOVA, with Type III (partial) sums of squares, unrestricted permutation of raw data and 999 permutations. Type III (partial) sums of squares was chosen as the most conservative model in which the order that terms are fitted is not important (Anderson et al. 2008). Unrestricted permutation of raw data was selected as Site was the only factor (Anderson et al. 2008). 
The effect of environmental parameters on assemblage structure was assessed both between and within sites using distance-based linear models (DISTLM). Prior to DISTLM, correlation matrices were produced in PRIMER 6 to identify co-correlating variables. Where pairs of variables had a Pearson's correlation coefficient of 0.9 or larger, one of the co-correlating variables was excluded in order to remove redundant variables from the analysis, in accordance with the methodology proposed by Anderson et al. (2008). Initially, DISTLM was run with topographic variables at different grid sizes (1 m, and grid focal means $3,5,7$ and 15) to assess which spatial scale best explained the assemblage structure observed. The native resolution of $1 \mathrm{~m}$ (covering an area of $1 \mathrm{~m}^{2}$ ) had the highest $R^{2}$ value for both the grouped variable and ungrouped variable models and was used for all further analyses.

DISTLM was initially performed using grouped variables and then with the environmental variables ungrouped to investigate which individual variables were driving the observed patterns of environmental association with assemblage structure. The groups were determined by data type; depth, topography (curvature, plan-curvature, profilecurvature, slope, and aspect: rugosity could not be calculated at native resolution), substratum (backscatter and all substratum types without obvious hydrothermal signatures), substratum hydrothermal (substratum that was hydrothermally altered, had obvious oxide deposits or hydrothermal structures, such as chimneys and mounds), biogenic (dead coral), biogenic hydrothermal (dead mussel shells) and habitat heterogeneity (the standard deviation of each environmental variable). Both the grouped and ungrouped DISTLM tests used selection based on the Akaike Information Criterion (AIC), step-wise selection procedure and 999 permutations. AIC selection was chosen as the method to create the most parsimonious model, as it adds a 'penalty' for increases in the number of the predictor variables (Anderson et al. 2008). Step-wise selection was chosen as it allows for both the addition and removal of a term to the model at each step (Anderson et al. 2008). Distance-based redundancy analysis (dbRDA) plots were used to provide the best possible 2D visualisation of DISTLM results for individual environmental variables, with samples identified by their SIMPROF assemblage and vectors proportional to their contribution to the total variation. 


\section{Results}

\subsection{General seabed characteristics of the study sites}

Seabed characteristics derived from multibeam bathymetry indicated that Proteus 1 and the Reference Site are very similar in terms of area, depth and slope, with only minor differences in terms of aspect (Table 2). Although measures of seabed curvature differed slightly between the two sites, small standard deviations suggested this was unlikely to result in differences in assemblage structure between sites. In general, the multibeamderived values for seabed characteristics indicated that the two sites were sufficiently similar in terms of depth and topography for the Reference Site to be considered as a potential preservation reference zone, should the benthic assemblages be similar.

Table 2. Topographic summary of Proteus 1 and the Reference Site. Means and standard deviations (SD) of topographic variables were calculated at native resolution $\left(1 \mathrm{~m}^{2}\right)$. The total area of each site was also calculated. *Northness and eastness were calculated as the cosine and sine, respectively, of the aspect values, which are unit less. ${ }^{*}$ Measures of curvature have units of $1 / 100$ (z units).

\begin{tabular}{|c|c|c|c|}
\hline \multirow[t]{2}{*}{ Variable } & \multirow[t]{2}{*}{ Measurement } & \multicolumn{2}{|l|}{ Site } \\
\hline & & Proteus 1 & Reference \\
\hline Area $\left(m^{2}\right)$ & - & 22389 & 22671 \\
\hline \multirow[t]{2}{*}{ Depth (m) } & Mean & 1437 & 1430 \\
\hline & SD & 8.59 & 9.41 \\
\hline \multirow[t]{2}{*}{ Northness* } & Mean & -1.00 & -0.92 \\
\hline & SD & 0.99 & 0.19 \\
\hline \multirow[t]{2}{*}{ Eastness* } & Mean & 0.00 & 0.40 \\
\hline & SD & 0.11 & -0.98 \\
\hline \multirow[t]{2}{*}{ Curvature $^{\star \star}$} & Mean & 0.16 & -0.13 \\
\hline & SD & 117.69 & 90.21 \\
\hline \multirow[t]{2}{*}{ Plan curvature ${ }^{\star *}$} & Mean & 3.99 & 0.27 \\
\hline & SD & 68.41 & 52.60 \\
\hline \multirow[t]{2}{*}{ Profile curvature ${ }^{\star \star}$} & Mean & 4.14 & 0.14 \\
\hline & SD & 61.47 & 46.98 \\
\hline \multirow[t]{2}{*}{ Slope $\left(^{\circ}\right)$} & Mean & 21.91 & 20.31 \\
\hline & SD & 12.36 & 10.63 \\
\hline
\end{tabular}




\subsection{Assemblage structure}

In total, 42 putative taxa (Table 3) were identified from 153 video samples across the two sites. PERMANOVA results indicated a significant difference in assemblage structure by Site $(\mathrm{df}=1, \mathrm{SS}=19840, \mathrm{MS}=19840$, Pseudo- $F=9.626, \mathrm{p}[$ perm $]=0.001)$. Cluster analysis, as visualised by MDS, indicated that faunal records from the $15 \mathrm{~m}$ video segments of the Reference Site grouped together but within a portion of the cluster of Proteus 1 segments (Fig. 2A).

SIMPROF analyses identified 11 assemblages across the two sites, which were visualised by MDS (Fig. 2B). Six assemblages were only found at Proteus 1 and five assemblages were found at both Proteus 1 and the Reference Site. No assemblages were unique to the Reference Site (Fig. 3). The mapped spatial distribution of assemblages at Proteus 1 were clustered; assemblages I - V existed in close proximity in a series of four clusters in the northwest, north, east and southeast sectors of the site; assemblages $\mathrm{VI}$ $\mathrm{XI}$ also grouped together but were predominantly found in the south, southwest and west (Fig. 3A). No pattern was apparent for the spatial distribution of assemblages at the Reference Site (Fig. 3B). Assemblages unique to Proteus 1 were characterised by one to three taxa, whereas assemblages shared between Proteus 1 and the Reference Site were characterised by two to 14 taxa (Table 3). The assemblages can be broadly grouped into types according to their dominant taxa; corals, crinoids and sponges (VII - IX); corals mixed (X and $\mathrm{XI}$ ); shrimps (VI); hydrothermal vent fauna (I - III); corals and the urchin Dermechinus horridus (IV and V) (Table 4). 
Table 3. Taxa identified during analysis of video segments. Where numbers are included in the name (e.g. Hexactinellidae 1) this indicates a distinct taxon was observed but it could not be identified to species level.

\begin{tabular}{|c|c|c|}
\hline Kingdom & Phylum & Taxon \\
\hline Bacteria & & Bacterial mat \\
\hline \multirow[t]{36}{*}{ Animalia } & \multirow[t]{5}{*}{ Porifera } & Hexactinellidae \\
\hline & & Farreidae/Euretidae \\
\hline & & Hexactinellidae 1 \\
\hline & & Farreidae/Euretidae 2 \\
\hline & & Lefroyella sp \\
\hline & \multirow[t]{17}{*}{ Cnidaria } & Anthozoa 1 \\
\hline & & Anthozoa 2 \\
\hline & & Alcyonacea \\
\hline & & Alcyonacea 8 \\
\hline & & Antipatharia \\
\hline & & Antipatharia 5 \\
\hline & & Metallogorgia sp 1 \\
\hline & & Primnoidae/Isididae \\
\hline & & Primnoidae/lsididae 1 \\
\hline & & Primnoidae/Isididae 2 \\
\hline & & Primnoidae/Isididae 3 \\
\hline & & Primnoidae/Isididae 5 \\
\hline & & Primnoidae/Isididae 9 \\
\hline & & Anthomastus sp \\
\hline & & Caryophyllidae/Dendrophyllidae \\
\hline & & Actiniaria \\
\hline & & Actiniaria 1 \\
\hline & \multirow[t]{6}{*}{ Echinodermata } & Asteroidea \\
\hline & & Brisingida \\
\hline & & Comatulida \\
\hline & & Echinoidea \\
\hline & & Echinothuriidae \\
\hline & & Dermechinus horridus \\
\hline & \multirow[t]{3}{*}{ Crustacea } & Caridea \\
\hline & & Munididae \\
\hline & & Alvinocarididae/Hippolytidae \\
\hline & Brachiopoda & Brachiopoda \\
\hline & Mollusca & Bathymodiolus sp \\
\hline & \multirow[t]{2}{*}{ Annelida } & Echiura 1 \\
\hline & & Echiura 2 \\
\hline & Chordata & Ascidiacea 2 \\
\hline
\end{tabular}




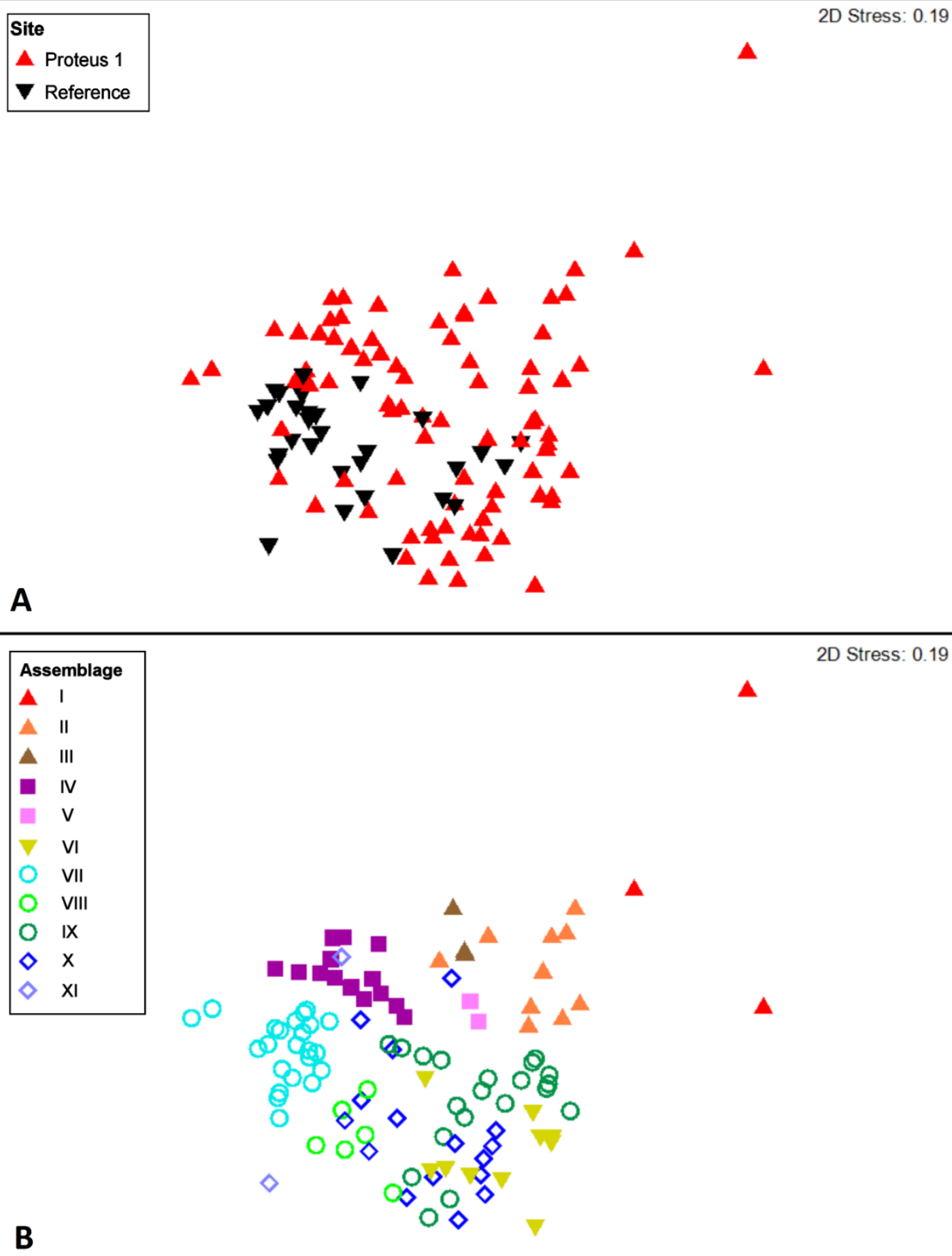

Figure 2. Non-metric Multi-dimensional scaling (MDS) plot of $15 \mathrm{~m}$ video samples labelled by (A) site (Proteus 1 and Reference) and (B) SIMPROF assemblages (I to XI). In 2B, assemblage symbols are as follows; filled upward pointing triangles: hydrothermal vent fauna; filled squares: corals and Dermechinus; filled downward triangles: shrimps; hollow circles: corals, crinoids and sponges; and hollow diamonds: mixed corals. Filled symbols: assemblages only found at Proteus 1, hollow symbols: assemblages found at both Proteus 1 and the Reference Site. 


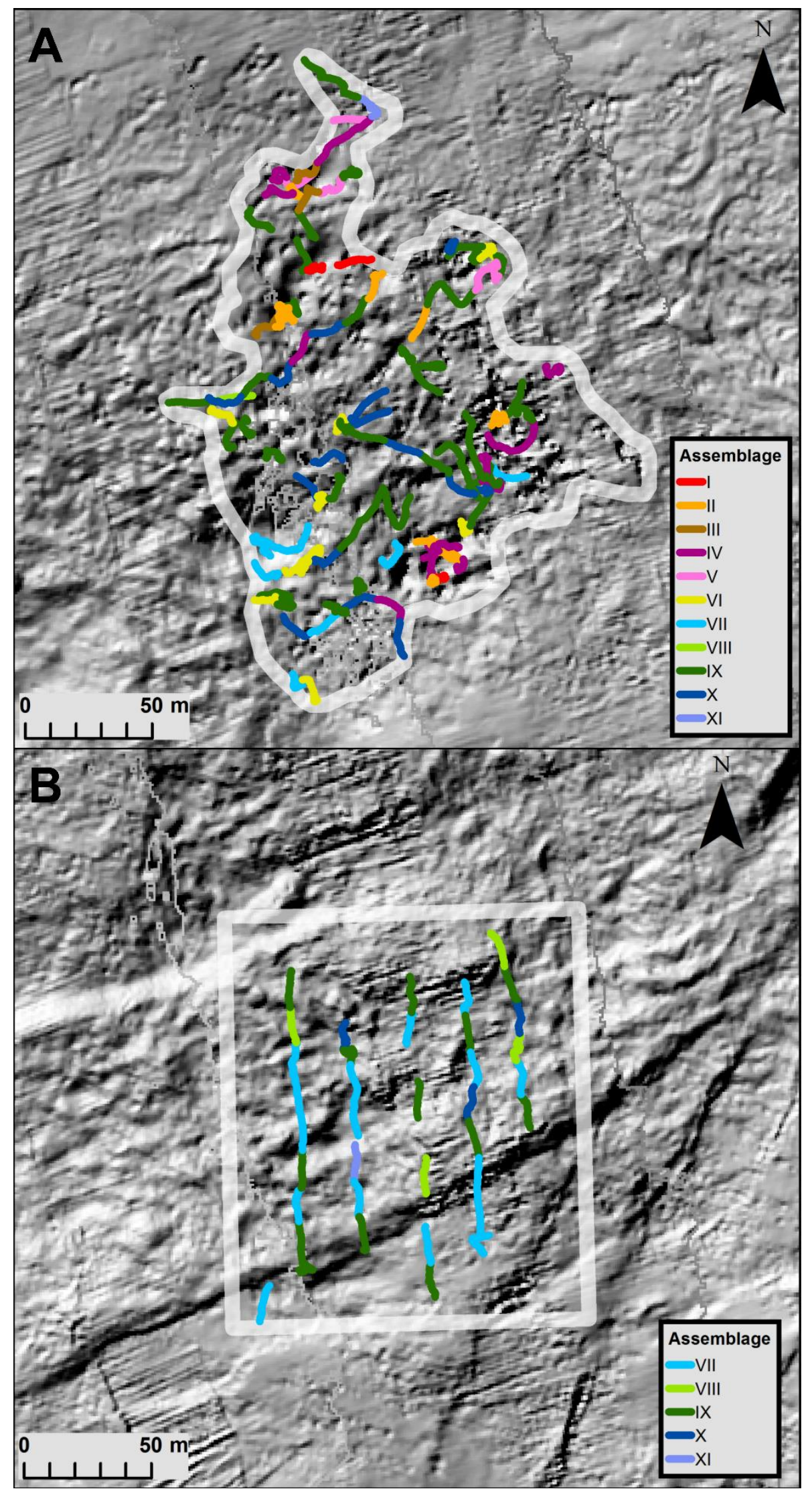

Figure 3. Digital terrain model maps of SIMPROF assemblage (I to $\mathrm{XI}$ ) distribution over Proteus 1 (A) and the Reference Site $(B)$. The thick pale grey lines indicate the spatial extent of each site. 
Table 4. Taxon composition determined by SIMPER for the SIMPROF assemblages (I to XI) at Proteus 1 and the Reference Site. Group similarity indicates the percentage similarity between 15 $\mathrm{m}$ samples within the assemblage group. The cut-off for cumulative percentage to group similarity was $99.9 \%$.

\begin{tabular}{|c|c|c|}
\hline $\begin{array}{l}\text { Assemblage } \\
\text { type }\end{array}$ & $\begin{array}{l}\text { Assemblage: } \\
\text { group } \\
\text { similarity (\%) }\end{array}$ & Taxa (contributing \% similarity) \\
\hline \multirow[t]{3}{*}{$\begin{array}{l}\text { Corals, } \\
\text { crinoids and } \\
\text { sponges }\end{array}$} & VII: 57.62 & 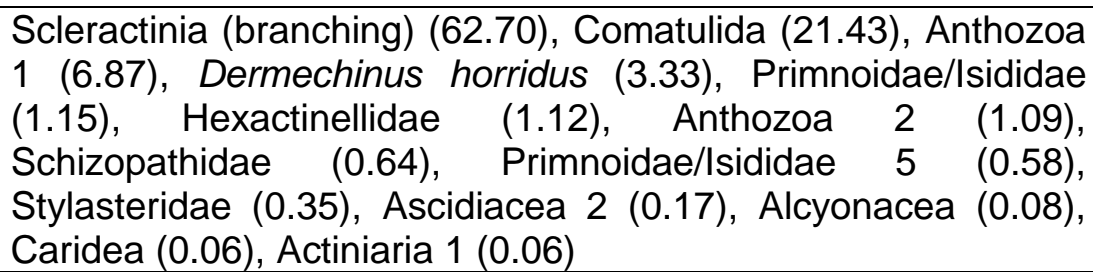 \\
\hline & VIII: 49.93 & 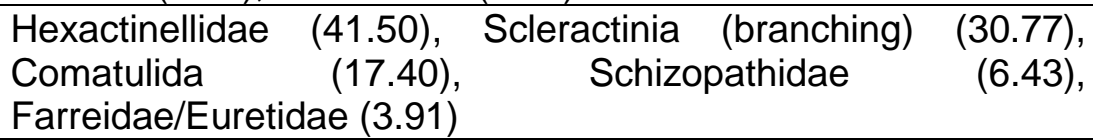 \\
\hline & IX: 2.76 & $\begin{array}{l}\text { Scleractinia (branching) (39.35), Hexactinellidae (36.03), } \\
\text { Anthozoa } 1 \text { (9.20), Comatulida (7.40), Primnoidae/lsididae } 3 \\
\text { (4.98), Actiniaria } 1 \text { (1.61), Antipatharia (1.42) }\end{array}$ \\
\hline \multirow[t]{2}{*}{ Corals mixed } & $\mathrm{X}: 43.22$ & $\begin{array}{l}\text { Schizopathidae (80.33), Anthozoa } 1 \text { (8.05), Primnoidae/lsididae } \\
\text { (5.24), Scleractinia (branching) (4.48), Dermechinus horridus } \\
\text { (0.91), Primnoidae/lsididae 5 }(0.39) \text {, Primnoidae/Isididae } 3 \\
\text { (0.37), Stylasteridae (0.24) }\end{array}$ \\
\hline & XI: 48.48 & Brachiopoda (69.10), Scleractinia (branching) (30.90) \\
\hline Shrimps & & Caridea (93.19), Comatulida (3.40), Schizopathidae (3.40) \\
\hline \multirow[t]{3}{*}{$\begin{array}{l}\text { Hydrothermal } \\
\text { vent fauna }\end{array}$} & I: 29.17 & $\begin{array}{l}\text { Bathymodiolus sp. (50.32), Vulcanolepas osheai (36.15), } \\
\text { Alvinocarididae/Hippolytidae (13.53) }\end{array}$ \\
\hline & II: 44.23 & Bacterial mat (67.05), Alvinocarididae/Hippolytidae (32.95) \\
\hline & & Dermechinus horridus (67.42), Bacterial mat (32.58) \\
\hline \multirow{2}{*}{$\begin{array}{l}\text { Corals and } \\
\text { Dermechinus } \\
\text { horridus }\end{array}$} & IV: 65.32 & $\begin{array}{l}\text { Scleractinia (branching) (53.80), Dermechinus horridus (42.72), } \\
\text { Bacterial mat (3.04), Anthozoa } 1 \text { (0.44) }\end{array}$ \\
\hline & $\mathrm{V}: 83.92$ & Dermechinus horridus (100.00) \\
\hline
\end{tabular}




\subsection{Environmental drivers of assemblage structure}

There were 34 individual variables available to the models, which were divided into seven groups. The environmental groups included in the best model $\left(A I C=1140.9, R^{2}=0.33\right.$, RSS $=2.207$ E5) were (in order of decreasing importance) biogenic, biogenic hydrothermal, depth, and substratum hydrothermal (Table 5). Using the ungrouped model, the individual variables that were included in the best model ( $A I C=1135.7, R^{2}=0.33$, RSS $=2.218$ E5) were (in order of decreasing importance) dead coral, chimney active, dead mussel shells, depth, sediment altered, standard deviation of slope, backscatter, volcaniclastic rock, chimney inactive, and talus oxide (Table 5). The importance of individual variables to the model was visualised in the $\operatorname{dbRDA}$ plot; vectors were proportional to their contribution to the total variation (Fig. 4). Interpreting the plot like a compass, the five longest vectors related to dead coral (westward); substrata indicative of hydrothermal activity (northward: chimney active; northwest: talus oxide and sediment altered); depth (southwest) and backscatter (southward). The corals, crinoid and sponge assemblages related most strongly to the dead coral vector; the hydrothermal vent fauna assemblages and the corals and $D$. horridus assemblages related to the vectors indicative of hydrothermal activity; the shrimp assemblages had the strongest association with depth; multiple assemblages were influenced by backscatter.

Table 5. DISTLM Pseudo- $F$ values when variables were made available to the model collectively (grouped) or individually (ungrouped). Displayed are the environmental variables and groups selected by DISTLM as part of the best model; '-' indicates the field is not applicable. SD: standard deviation.

\begin{tabular}{|l|l|l|l|}
\hline Model & Environmental Group & Environmental variable & Pseudo- $\boldsymbol{F}$ values \\
\hline \multirow{4}{*}{ Grouped } & Biogenic & - & 36.40 \\
\cline { 2 - 4 } & Biogenic hydrothermal & - & 3.95 \\
\cline { 2 - 4 } & Depth & - & 3.97 \\
\cline { 2 - 4 } & Substrata hydrothermal & - & 2.05 \\
\hline \multirow{5}{*}{ Ungrouped } & Biogenic & Dead coral & 36.40 \\
\cline { 2 - 4 } & Biogenic hydrothermal & Dead mussel shells & 4.06 \\
\cline { 2 - 4 } & Depth & Depth & 4.08 \\
\cline { 2 - 4 } & Substrata hydrothermal & Chimney active & 5.60 \\
\cline { 2 - 4 } & Sediment altered & 2.99 \\
\cline { 2 - 4 } & Chimney inactive & 1.88 \\
\cline { 2 - 4 } & Talus oxide & 2.10 \\
\cline { 2 - 4 } & Substrata & Backscatter & 2.16 \\
\cline { 2 - 4 } & & Volcaniclastic rock & 1.92 \\
\cline { 2 - 4 } & Habitat heterogeneity & Slope (SD) & 2.14 \\
\hline
\end{tabular}




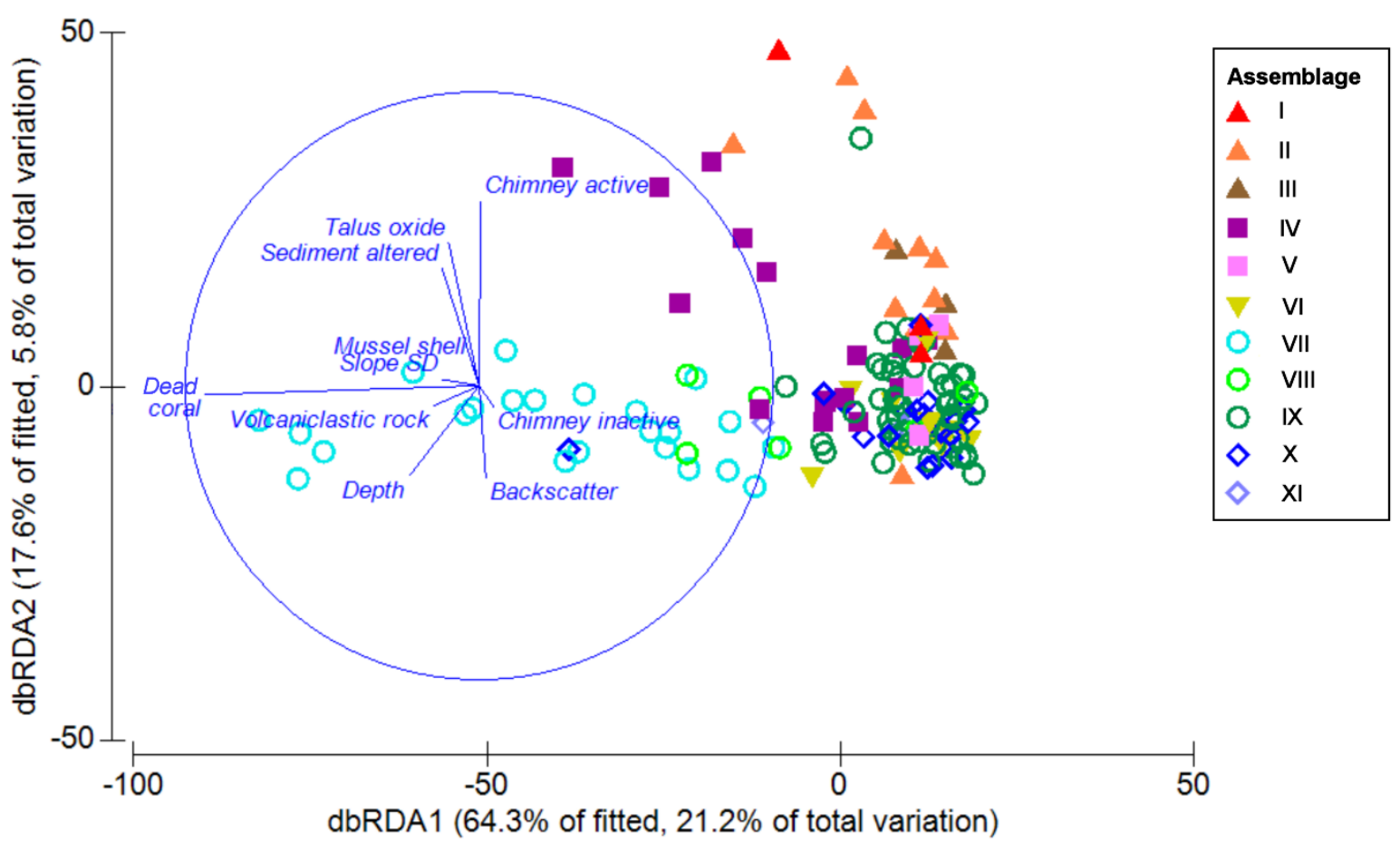

Figure 4. Distance-based redundancy analysis (dbRDA) plot to visualise DISTLM results in 2dimensional space for individual environmental variables across the two sites, Proteus 1 and the Reference Site. The coloured symbols represent SIMPROF assemblages (I to XI). Assemblage symbols are as follows; filled upward pointing triangles: hydrothermal vent fauna; filled squares: corals and Dermechinus; filled downward triangles: shrimps; hollow circles: corals, crinoids and sponges; and hollow diamonds: mixed corals. Filled symbols: assemblages only found at Proteus 1; hollow symbols: assemblages found at both Proteus 1 and the Reference site. Vectors length is proportional to their contribution to the total variation (see Table 4).

\section{Discussion}

The video survey at Rumble II West Seamount provided a detailed view of faunal assemblages at the potential mine site Proteus 1 and the Reference Site. These data were at a spatial scale sufficient to compare faunal assemblages between the two sites, consider the suitability of the Reference Site as a protected area, and to provide recommendations on environmental management in the region.

\subsection{Structure of assemblages shared between Proteus 1 and the Reference Site}

Proteus 1 and the Reference Site shared five megafaunal benthic assemblages. These were relatively diverse, and could be broadly split into two types; 1) Corals, crinoids and sponges, and 2) Mixed corals assemblages. In both cases, branching stony coral 
contributed more than $30 \%$ to the assemblage group similarity; these corals were also a significant component of some of the assemblages identified during a previous study at Rumble II West Seamount (Boschen et al. 2015). Video observations in the present study indicated the branching stony coral matrix provided a platform for other filter-feeding fauna, such as comatulid crinoids, actiniarian anemones, hexactinellid sponges, ascidians, brachiopods and various corals (e.g. antipatharian, schizopathid, primnoid/isidid). Thus, diverse filter feeding assemblages were established at both Proteus 1 and the Reference Site, with as many as 14 taxa identifiable from video footage (Fig. 5A). These associations highlight the importance of 'Biogenic' in the DISTLM grouped model and that of 'Dead coral' in explaining variation in assemblage structure in the ungrouped model.

\subsection{Structure of assemblages unique to Proteus 1}

There were six assemblages found only at the prospective mine site, Proteus 1 . These could be broadly separated into three types; 1) Shrimps, 2) Hydrothermal vent fauna, and 3) Corals and Dermechinus assemblages. The Shrimps assemblage was dominated by non-vent caridean shrimps; a similar assemblage was found in an earlier study at Rumble II West and Brothers seamounts and was attributed to vent association (Boschen et al. 2015).

The Hydrothermal vent fauna assemblages (Fig. 5B - D) consisted of bacterial mat, vent shrimps, stalked barnacles, bathymodiolid mussels, and occasionally the urchin $D$. horridus. Bacterial mat was observed either on the flanks of hydrothermally active mounds or on the sides of active chimneys (Fig. 5B) and in association with stalked barnacles and bathymodiolid mussels (Fig. 5D). Members of the alvinocarid/hippolytid vent shrimp category from the present study were also the dominant components of hydrothermal assemblages at Brothers Seamount, $100 \mathrm{~km}$ to the northeast of Proteus 1 (Boschen et al. 2015). There are five vent shrimp species found at seamounts along the Kermadec Volcanic Arc (Ahyong 2009); A. alexander, Alvinocaris longirostris, Alvinocaris niwa, Nautilocaris saintlaurentae and $L$. wera; all except $N$. saintlaurentae are endemic to the Kermadec Volcanic Arc. The Vulcanolepas osheai (previously Neolepas osheai) stalked barnacles at Proteus 1 were originally described from Brothers Seamount (Buckeridge 2000) and appear to be endemic to Brothers and Rumble II West seamounts (Clark and O'Shea 2001, Rowden et al. 2003, Clark et al. 2010, Beaumont and Rowden 2011). Three different species of hydrothermal vent mussels occur at multiple locations at vents along the Kermadec Volcanic Arc; Bathymodiolus manusensis, V. insolatus and G. gladius (Von Cosel and Marshall 2003, 2010); both V. insolatus and G. gladius are endemic to the New 
Zealand EEZ. The vent mussels at Proteus 1 could not be identified to species from the video footage but a physical sample collected during the survey indicates they could be an undescribed species (Bruce Marshall, The National Museum of New Zealand Te Papa Tongarewa, personal communication).

The occurrence of hydrothermal vent assemblages explains the importance of 'biogenic hydrothermal' and 'substrata hydrothermal' to the grouped DISTLM model and the contribution of 'dead mussel shells', 'chimney active', 'sediment altered', 'chimney inactive' and 'talus oxide' to the ungrouped model. The location of all the vent fauna observed at Proteus 1 and the corresponding hydrothermal areas can be seen in Fig. 6, with the main areas of hydrothermal activity in the northwest, east and southeast of the site. The significance of 'backscatter' and 'slope' in the DISTLM model probably relates to the occurrence of chimney structures and their influence on these seabed properties. Chimneys could also explain the significance of depth in the model; the range in average depth of video segments was 1436 - $1447 \mathrm{~m}$ at Proteus 1 and $1412-1443 \mathrm{~m}$ at the Reference Site. That such a small variation in depth would have a significant influence on assemblage structure is surprising, but when chimneys can be $1-10 \mathrm{~m}$ high, the presence or absence of chimneys within a video segment could considerably influence the average depth.

The corals and Dermechinus assemblages at the Proteus 1 site consisted of either the urchin $D$. horridus or a combination of $D$. horridus, branching scleractinian coral, a whip-like coral and bacterial mat. The proximity of coral and Dermechinus assemblages to hydrothermal areas suggests these taxa may benefit from consuming hydrothermal secondary production; non-vent communities in the Manus Basin were found to incorporate vent-derived material in their diet (Erickson et al. 2009). Video observations indicate that the coral and Dermechinus assemblages occur predominantly on inactive chimneys (Figs. 5E - F) and that inactive chimneys supporting these assemblages can occur in close proximity to active vents (Fig. 5B). Although urchins are not generally considered to be suspension feeders, there is some morphological and in situ evidence that $D$. horridus is able to feed on suspended matter (Fell 1976). By inhabiting tall chimney structures in close proximity to hydrothermal activity, suspension feeding corals and urchins would benefit from increased current flow and food supply; a relationship that is supported by the importance of 'chimney active' and 'chimney inactive' in the ungrouped DISTLM model, although not all inactive chimney structures support corals and Dermechinus assemblages (Fig. 5C). 


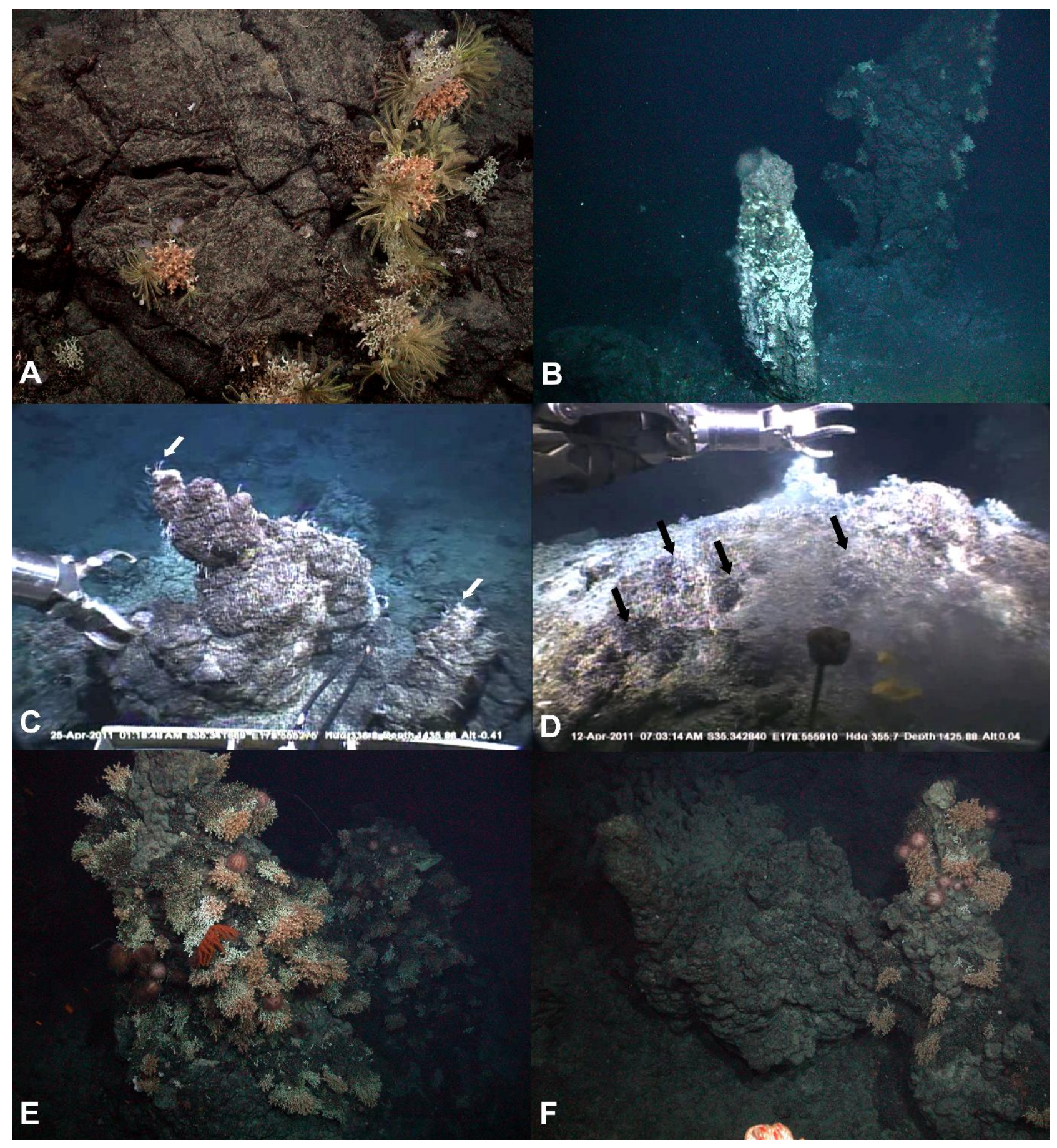

Figure 5. In situ seabed images including (A) corals, crinoids and sponges assemblages; (B-D) hydrothermal vent fauna assemblages; (E, F) corals and Dermechinus assemblages. Note not all inactive chimneys were colonised $(F)$ and inactive chimneys existed in close proximity to active chimneys (B). Arrows indicate Vulcanolepas osheai stalked barnacles (C) and Bathymodiolus sp. mussels (D). Images A, B, E and F were ROV stills, C and D are video frame grabs. Image credit: Neptune Minerals Inc. 


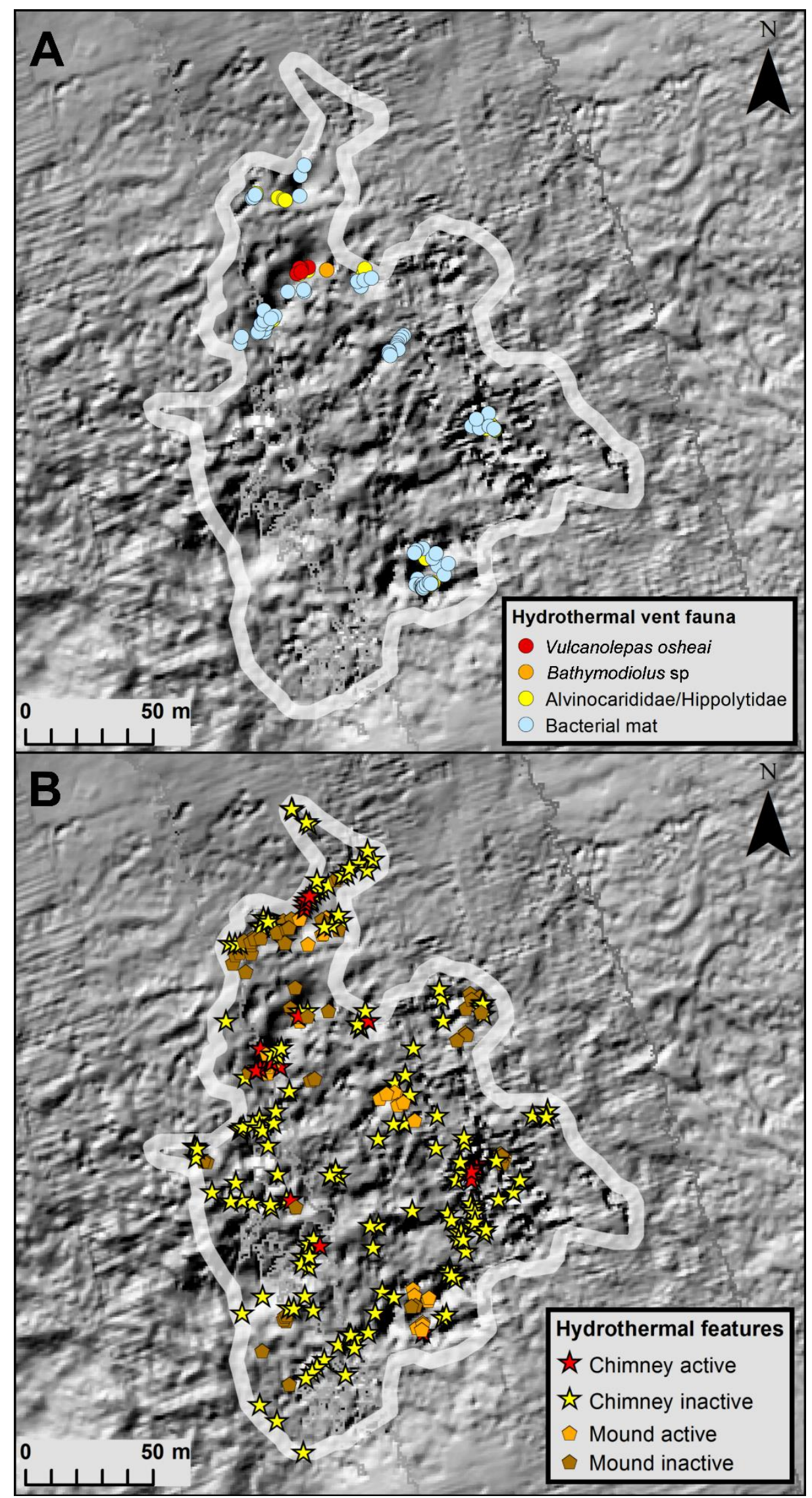

Figure 6. Location of $(A)$ hydrothermal vent fauna and bacterial mat, and $(B)$ hydrothermal features within the Proteus 1 site, as determined by video observations. 


\subsection{Implications for seabed mining and conservation}

Although five assemblages were shared between Proteus 1 and the Reference Site, six assemblages were unique to Proteus 1 . This means that the Reference Site is not a comprehensive representation of the biodiversity patterns present at Proteus 1 , and would therefore probably not on its own be a suitable preservation reference zone for any future proposed mining. However, the occurrence of assemblages shared between the sites indicates that the Reference Site could form part of a network of preservation sites that in combination represent the biological characteristics of Proteus 1. Depending on local current flow, which has not been characterised to date, the close proximity of the Reference Site to Proteus $1(200 \mathrm{~m})$ could impede its suitability as a preservation reference zone; sedimentation impacts at Solwara 1, a prospective SMS mine site in the Manus Basin, were predicted to extend to $1 \mathrm{~km}$ away from mining activity (Coffey Natural Systems 2008).

The occurrence of the corals and Dermechinus assemblages provides evidence for the hypothesised third community at SMS deposits; one unique to inactive sulfides. Although the corals and Dermechinus assemblages are not specifically adapted to the geological and microbial conditions of weathering sulfides as previously hypothesised (Van Dover 2011), assemblages dominated by large populations of Dermechinus only occur at these inactive SMS areas and so can be considered 'unique'. Although Dermechinus is found at other locations along the Kermadec Volcanic Arc and in the wider region, their occurrence in densities sufficiently large to dominate the assemblage appears to be related to inactive SMS areas, as documented in this study on Rumble II West. The discovery of unique assemblages at inactive SMS areas strongly supports their inclusion within conservation measures, such as preservation reference zones. These assemblages could be particularly at risk from mining activities; they have not been observed elsewhere on seamounts in the region to date, and suspension feeding taxa could be vulnerable to any turbidity plumes created during mining. Recovery of these assemblages after chimney removal is uncertain; once the inactive chimneys are removed suitable habitat may not be available for recolonisation. Equally, video observations indicate that not all chimneys support these assemblages and the distribution of assemblages can differ between sides of chimneys (Figs. $5 \mathrm{~B}, \mathrm{~F}$ ). Hence, there may be differences in the chemical and microbial composition, or food supply due to current flow, that affects chimney colonisation and the distribution of assemblages.

In the event that suitable inactive chimney habitat is available, it could still take centuries to establish mature corals and Dermechinus assemblages. Radiocarbon dating 
for the stony coral Solenosmilia variablis (the branching coral largely observed in this study), estimated the age of a colony recovered from off Tasmania at a similar depth (1454 $\mathrm{m}$ compared to $1437 \mathrm{~m}$, the mean depth of Proteus 1) to have a linear growth rate of 1.25 $\mathrm{mm} \mathrm{yr}^{-1}$ (Fallon et al. 2014). The absence of laser-scaling in the ROV imagery in the present study means that the size of in situ coral matrices cannot be measured accurately, however visual estimates suggest the coral colonies on Proteus 1 inactive chimneys are at least $20 \mathrm{~cm}$ high and could therefore be at least 160 years old.

A further complication for management is that the different SMS environments at Proteus 1 support different hydrothermal communities; the vent orifices and chimneys are colonised by bacterial mat and occasionally vent shrimps, whilst areas of lower level hydrothermal activity support stalked barnacles and bathymodiolid mussels. The patchy spatial distribution of these vent assemblages, the continuum of hydrothermal activity and the potential for a locally endemic species of bathymodiolid vent mussel makes establishing a single preservation reference zone with the same characteristics of Proteus 1 a challenging task. The diversity of assemblages and SMS environments at Proteus 1 is better suited to a network of preservation reference zones. This finding supports the management recommendations of a regional study (Boschen et al. 2015), where it was considered necessary to protect a network of areas within and amongst neighbouring seamounts to adequately preserve the assemblages present in areas that could potentially be licenced for SMS mining along the Kermadec Volcanic Arc.

The present and previous studies demonstrate the importance of studies conducted at multiple spatial scales; the regional significance of a potential preservation area can only be determined by a large-scale survey (Boschen et al. 2015), whilst the complex spatial heterogeneity of habitats and assemblages within an SMS deposit can only be accommodated by a site-scale survey, as detailed in the present study. This site-scale analysis is particularly important given the close proximity of potentially unique assemblages to prospective mine sites. Combining information from site-scale and largescale regional studies enables more robust recommendations to be made that not only inform site-level decisions made by SMS mining companies and environmental regulators, but also support the establishment of regional environmental management plans for SMS mining. These studies also illustrate the importance for selecting preservation areas based on quantitative data rather than reliance on geophysical proxies. 


\section{Acknowledgements}

We thank the crew and scientists aboard RV Dorado Discovery during the 2011 survey of seamounts on the Kermadec Volcanic Arc. We thank Neptune Minerals Inc. for making the video footage and environmental data available for use in this study, and supporting us to publish our findings in the scientific literature in accordance with the Code for Environmental Management of Marine Mining adopted by the International Marine Minerals Society. We also thank Jenny Beaumont (NIWA) for assistance with accessing the Neptune Minerals Inc. data; David Bowden (NIWA) for support with video analysis software; and Owen Anderson (NIWA) for comments on Dermechinus horridus ecology. REB was supported by PhD scholarship funding from NIWA and Victoria University of Wellington. This study is part of the NIWA project 'Deep-sea mining of the Kermadec Arc e Geophysical prospectivity and environmental impacts' funded by the New Zealand Ministry of Business, Innovation and Employment (formally the Foundation for Research, Science and Technology) (Contract C01X0702). We would also like to thank two anonymous reviewers of the manuscript for their constructive comments.

\section{References}

Ahyong S (2009) New species and new records of hydrothermal vent shrimps from New Zealand (Caridea: Alvinocarididae, Hippolytidae). Crustaceana 82, 775-794.

Anderson MJ (2006) Distance-based tests for homogeneity of multivariate dispersions. Biometrics 62, 245-253.

Anderson MJ, Gorley RN, Clarke KR (2008) PERMANOVA for PRIMER: guide to software and statistical methods. PRIMER-E, Plymouth, UK, 214 pp.

Baker E, Beaudoin $Y$ (eds.) (2013) Deep sea minerals: sea floor massive sulphides, a physical, biological, environmental, and technical review, Vol $1 \mathrm{~A}$. Secretariat of the Pacific Community, 52 pp.

Beaumont J, Rowden AA (2011) Preliminary observations on the biological communities at selected seamount sites on the Kermadec Volcanic Arc. National Institute of Water and Atmospheric Research, Wellington, New Zealand, 85 pp.

Boschen RE, Rowden AA, Clark MR, Barton SJ, Pallentin A, Gardner JPA (2015) Megabenthic assemblage structure on three New Zealand seamounts: implications for seafloor massive sulfide mining. Marine Ecology Progress Series 523, 1-14.

Boschen RE, Rowden AA, Clark MR, Gardner JPA (2013) Mining of deep-sea seafloor massive sulfides: a review of the deposits, their benthic communities, impacts from 
mining, regulatory frameworks and management strategies. Ocean and Coastal Management 84, 54-67.

Buckeridge JS (2000) Neolepas osheai sp. nov., a new deep-sea vent barnacle (Cirripedia: Pedunculata) from the Brothers Caldera, South-West Pacific Ocean. New Zealand Journal of Marine and Freshwater Research 34, 409-418.

Clark MR, Consalvey M, Baird SJ, Schnabel KE, Stewart R, Mitchell J, Hart A, Herrera S, Beaumount J, Hill P, Schwarz J, Holman M (2010) Voyage report of a survey of seamounts on the southern Kermadec Arc (TAN1007): second leg, biology. National Institute of Water and Atmospheric Research, Wellington, New Zealand, 48 pp.

Clark MR, O'Shea S (2001) Hydrothermal vent and seamount fauna from the southern Kermadec Ridge, New Zealand. InterRidge News 10, 14-17.

Clarke KR, Gorley RN (2006) PRIMER v6: User manual/tutorial. PRIMER-E, Plymouth, UK, $190 \mathrm{pp}$.

Clarke KR, Somerfield PJ \& Chapman MG (2006) On resemblance measures for ecological studies, including taxonomic dissimilarities and a zero-adjusted Bray-Curtis coefficient for denuded assemblages. Journal of Experimental Marine Biology and Ecology 330, 55-80.

Coffey Natural Systems (2008) Environmental Impact Statement, Solwara 1 project, Nautilus Minerals Niugini limited, Main Report, Vol A. Coffey Natural Systems, Brisbane, Australia, $222 \mathrm{pp}$.

Collins PC, Kennedy R, Copley JC, Boschen RE, Forde J, Se-Jong J, Lindsay D, Marsh L, Nye V, Patterson A, Watanabe H, Yamamoto H, Carlsson J, Thaler AD (2013) VentBase: developing a consensus among stakeholders in the deep-sea regarding environmental impact assessment for deep-sea mining - a workshop report. Marine Policy 42, 334-336.

Collins PC, Kennedy R, Van Dover CL (2012) A biological survey method applied to seafloor massive sulphides (SMS) with contagiously distributed hydrothermal-vent fauna. Marine Ecology Progress Series 452, 89-107.

Costello MJ (2014) Long live marine reserves: a review of experiences and benefits. Biological Conservation 176, 289-296.

de Ronde CEJ, Massoth GJ, Butterfield DA, Christenson BW, Ishibashi J, Ditchburn RG, Hannington MD, Braithwaite RL, Lupton JE, Kamenetsky VS, Graham IJ, Zellmer GF, Dziak RP, Embley RW, Dekov VM, Munnik F, Lahr J, Evans LJ, Takai K (2011) Submarine hydrothermal activity and gold-rich mineralization at Brothers Volcano, Kermadec Arc, New Zealand. Mineralium Deposita 46, 541-584. 
Erickson KL, Macko SA, Van Dover CL (2009) Evidence for a chemoautotrophically based food web at inactive hydrothermal vents (Manus Basin). Deep-Sea Research Part IITopical Studies in Oceanography 56, 1577-1585.

Fallon SJ, Thresher RE, Adkins J (2014) Age and growth of the cold-water scleractinian Solenosmilia variabilis and its reef on SW Pacific seamounts. Coral Reefs 33, 31-38.

Fell, FJ. (1976) The Cidaroidea (Echinodermata: Echinoidea) of Antarctica and the Southern Oceans. Doctor of Philosophy, University of Maine, ME, 294 pp.

Galkin SV (1997) Megafauna associated with hydrothermal vents in the Manus Back-Arc Basin (Bismarck Sea). Marine Geology 142, 197-206.

Geldmann J, Barnes M, Coad L, Craigie ID, Hockings M, Burgess ND (2013) Effectiveness of terrestrial protected areas in reducing habitat loss and population declines. Biological Conservation 161, 230-238.

Grassle JF (1985) Hydrothermal vent animals: distribution and biology. Science 229, 713717.

Green AL, Fernandes L, Almany G, Abesamis R, McLeod E, Alino PM, White AT, Salm R, Tanzer J, Pressey RL (2014) Designing marine reserves for fisheries management, biodiversity conservation, and climate change adaptation. Coastal Management 42, 143-159.

Hannington M, Jamieson J, Monecke T, Petersen S, Beaulieu S (2011) The abundance of seafloor massive sulfide deposits. Geology 39, 1155-1158.

International Seabed Authority (2010) Regulations on prospecting and exploration for polymetallic sulphides in the Area. ISBA/16/A/12/Rev.1. International Seabed Authority, Kingston, Jamaica, 49 pp.

International Seabed Authority (2014) Deep sea minerals contractors [Online]. Available: https://www.isa.org.jm/deep-seabed-minerals-contractors?atcontractors tabs alt=1\#qt-contractors tabs alt (accessed October $25^{\text {th }}$ 2015).

Kimmerling AJ, Buckley AR, Muehrchke PC, Muehrchke JO (2011) Map use: reading analysis interpretation, seventh ed. ESRI, $610 \mathrm{pp}$.

Krasnov SG, Cherkashev GA, Stepanova TV, Batuyev BN, Krotov AG, Malin BV, Maslov MN, Markov VF, Poroshina IM, Samovarov MS, Ashadze AM, Lazareva LI, Ermolayev IK (1995) Detailed geological studies of hydrothermal fields in the North Atlantic. In: Parson LM, Walker CL, Dixon DR (eds.) Hydrothermal vents and processes, Vol 87. Geological Society of London, London, UK, pp 43-64.

Linke S, Trak E, Nel J (2011) Freshwater conservation planning: the case for systematic approaches. Freshwater Biology 56, 6-20. 
Lutz RA, Shank TM, Fornari DJ, Haymon RM, Lilley MD, Vondamm KL, Desbruyères $D$ (1994) Rapid growth at deep-sea vents. Nature 371, 663-664.

Neptune Minerals Inc. (2015) Tenements [Online]. Available: http://www.neptuneminerals.com/our-business/tenements/ (accessed October 25 2015).

New Zealand Petroleum and Minerals (2014) Online permitting system [Online]. Available: https://permits.nzpam.govt.nz/aca/ (accessed October $25^{\text {th }}$ 2015).

Partnership for Interdisciplinary Studies of Coastal Oceans (2007) The science of marine reserves [Online]. Available: www.piscoweb.org (accessed October 3rd 2015).

Pressey RL, Botrill MC (2009) Approaches to landscape- and seascape-scale conservation planning: convergence, contrasts and challenges. Oryx 43, 464-475.

Ramirez-Llodra E, Tyler PA, Baker MC, Bergstad OA, Clark MR, Escobar E, Levin, LA, Menot L, Rowden AA, Smith CR, Van Dover CL (2011) Man and the last great wilderness: human impact on the deep sea. Plos One 6, 8, e22588.

Rowden AA, Clark MR, O'Shea S, Mcknight DG (2003) Benthic biodiversity of seamounts on the southern Kermadec Volcanic Arc. Marine Biodiversity Biosecurity Report 3, National Institute of Water and Atmospheric Research, Wellington, New Zealand, 23 $\mathrm{pp}$.

Tunnicliffe V, Embley RW, Holden JF, Butterfield DA, Massoth GJ \& Juniper SK (1997) Biological colonization of new hydrothermal vents following an eruption on Juan de Fuca Ridge. Deep-Sea Research Part I-Oceanographic Research Papers 44, 16271644.

United Nations Environment Programme (2011) Strategic plan for biodiversity 2011-2020: Further information related to the technical rational for the Aichi Biodiversity Targets, including potential indicators and milestones. Conference of the parties to the convention on biological diversity, 14 March 2011 Nagoya, Japan. UNEP/CBD/COP/10/INF/12/Rev.1, 31 pp.

Van Dover CL (2000) The ecology of deep-sea hydrothermal vents. Princeton University Press, Princeton, NJ, 424 pp.

Van Dover CL (2011) Mining seafloor massive sulphides and biodiversity: what is at risk? ICES Journal of Marine Science 68, 341-348.

Van Dover CL (2014) Impacts of anthropogenic disturbances at deep-sea hydrothermal vent ecosystems: a review. Marine Environmental Research 102, 59-72. 
Von Cosel R, Marshall BA (2003) Two new species of large mussels (Bivalvia: Mytilidae) from active submarine volcanoes and a cold seep off the eastern North Island of New Zealand, with description of a new genus. Nautilus 117, 2, 31-46.

Von Cosel R, Marshall BA (2010) A new genus and species of large mussel (Mollusca: Bivalvia: Mytilidae) from the Kermadec Ridge. Tuhinga 21, 59-73.

Watson JEM, Dudley N, Segan DB, Hockings M (2014) The performance and potential of protected areas. Nature 515, 67-73. 


\section{Supplementary information}

Non-metric Multi-dimensional scaling (MDS) plots for video segment length trials.

Data were square-root transformed, with a zero-adjusted Bray-Curtis resemblance matrix.

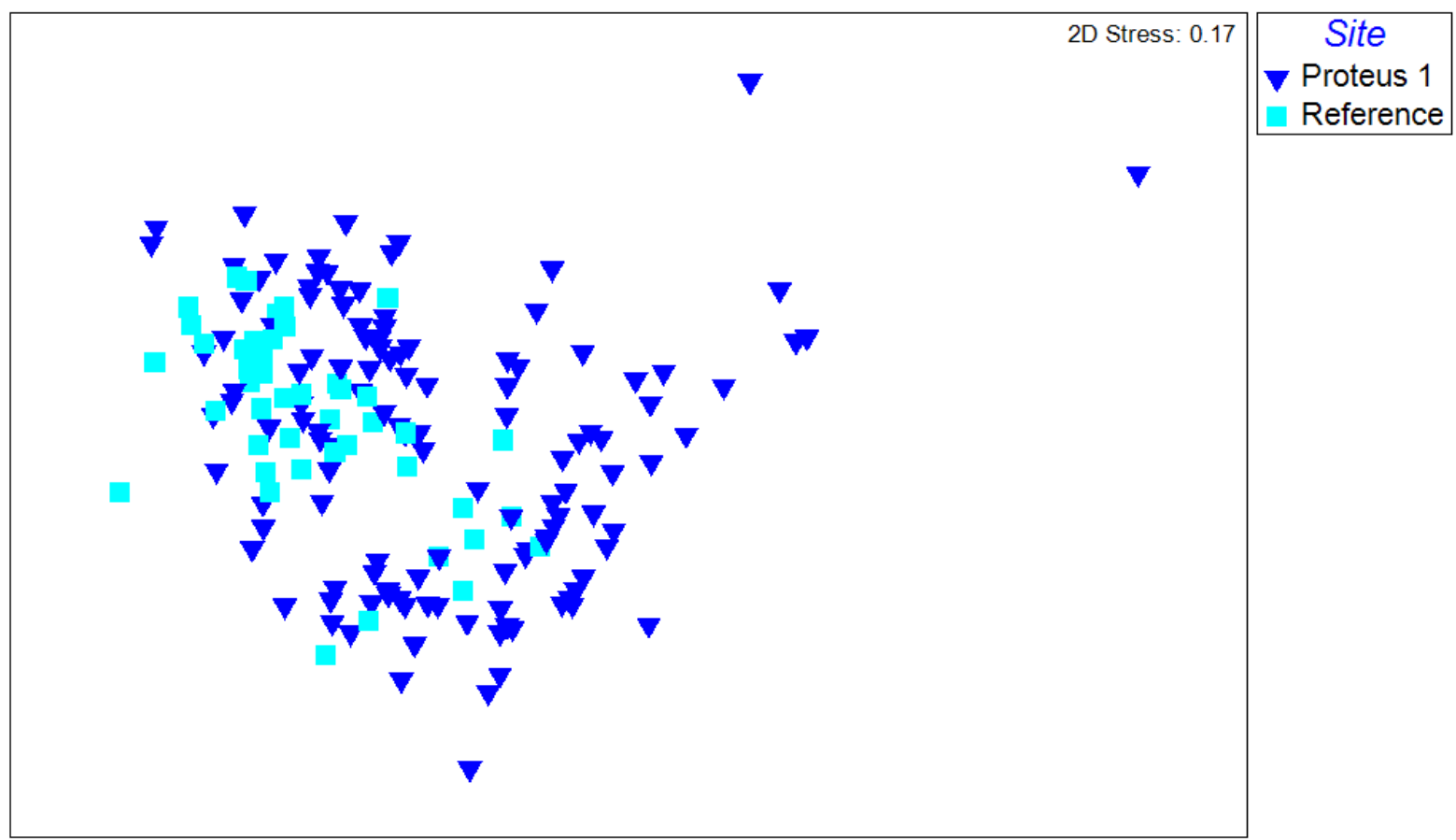

Figure S1. MDS plot of $10 \mathrm{~m}$ video segments, plotted by site. Dark blue triangles: Proteus 1; light blue squares: Reference Site.

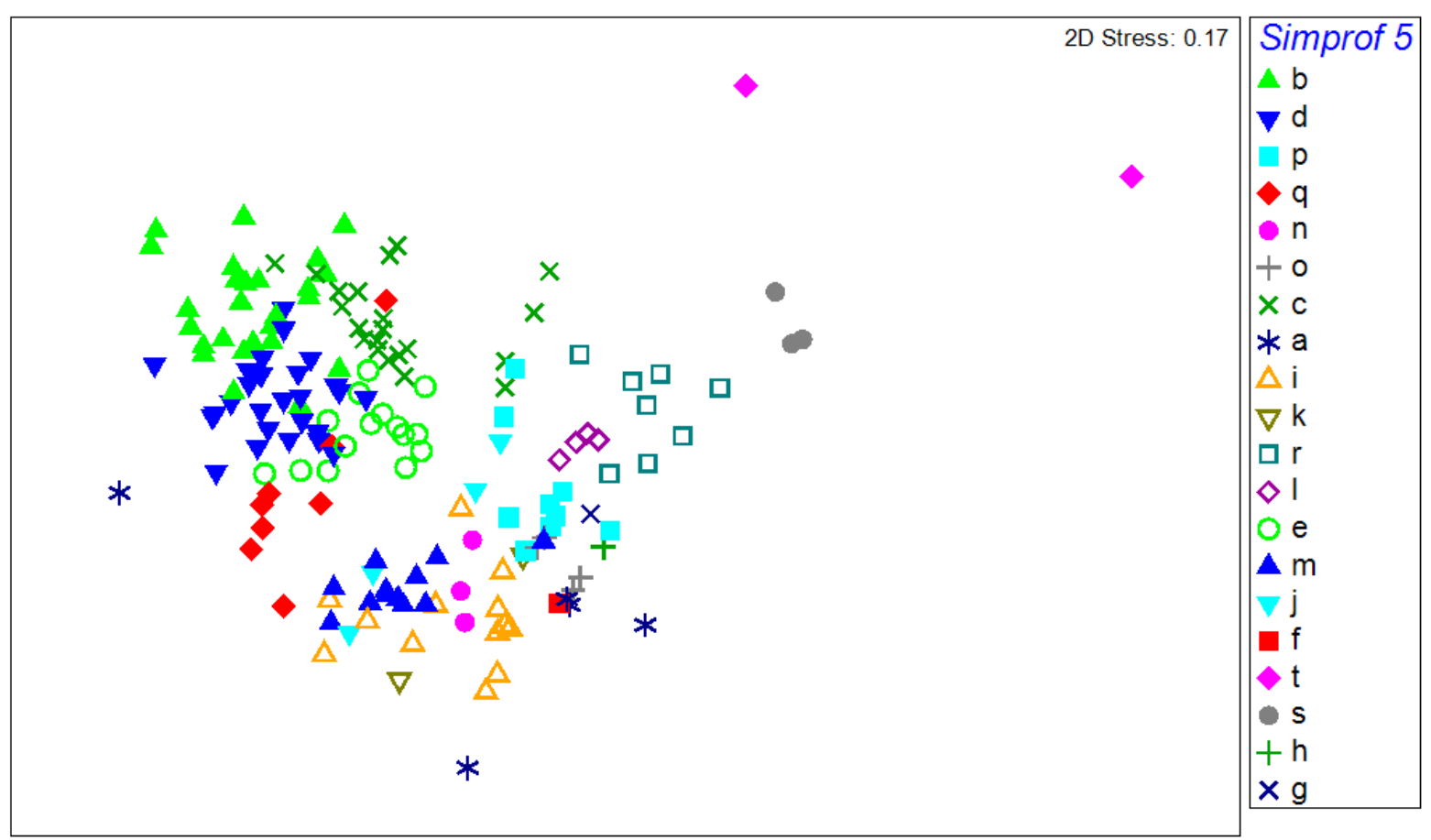

Figure S2. MDS plot of $10 \mathrm{~m}$ video segments, plotted by SIMPROF assemblage $(p=0.05)$. Each different colour/shape of symbol represents an assemblage type. 


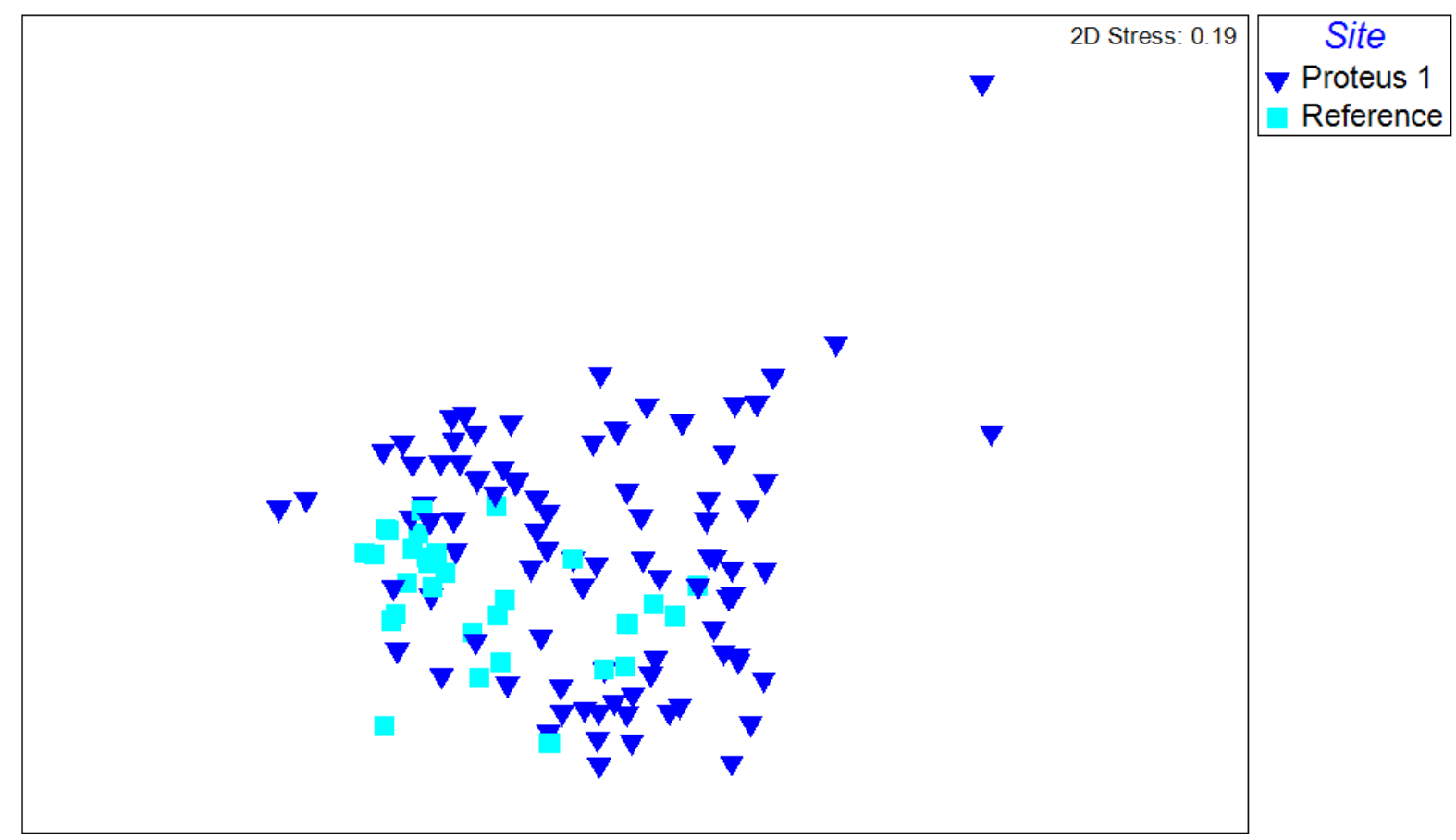

Figure S3. MDS plot of $15 \mathrm{~m}$ video segments, plotted by site. Dark blue triangles: Proteus 1; light blue squares: Reference Site.

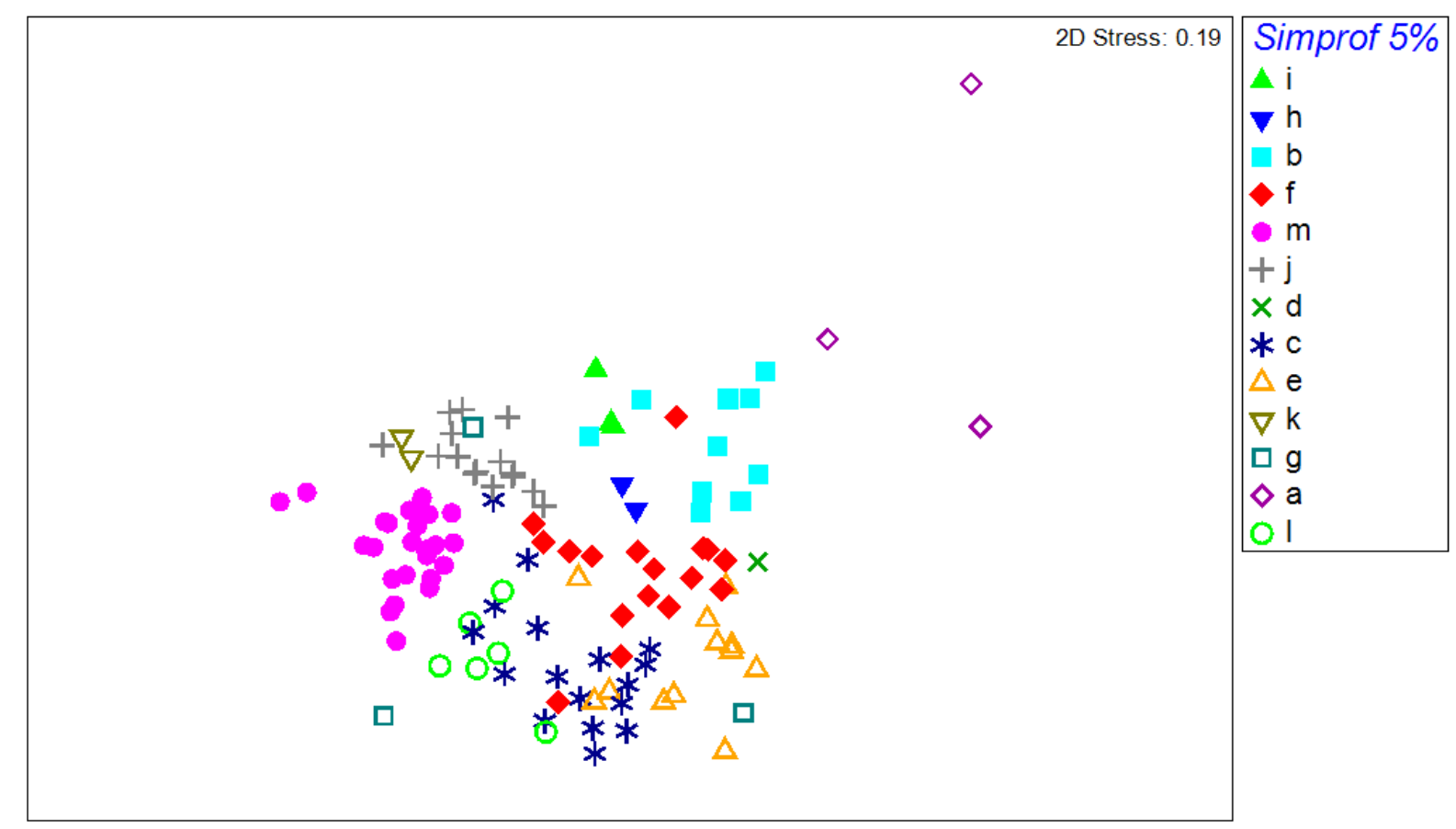

Figure S4. MDS plot of $15 \mathrm{~m}$ video segments, plotted by SIMPROF assemblage $(p=0.05)$. Each different colour/shape of symbol represents an assemblage type. 


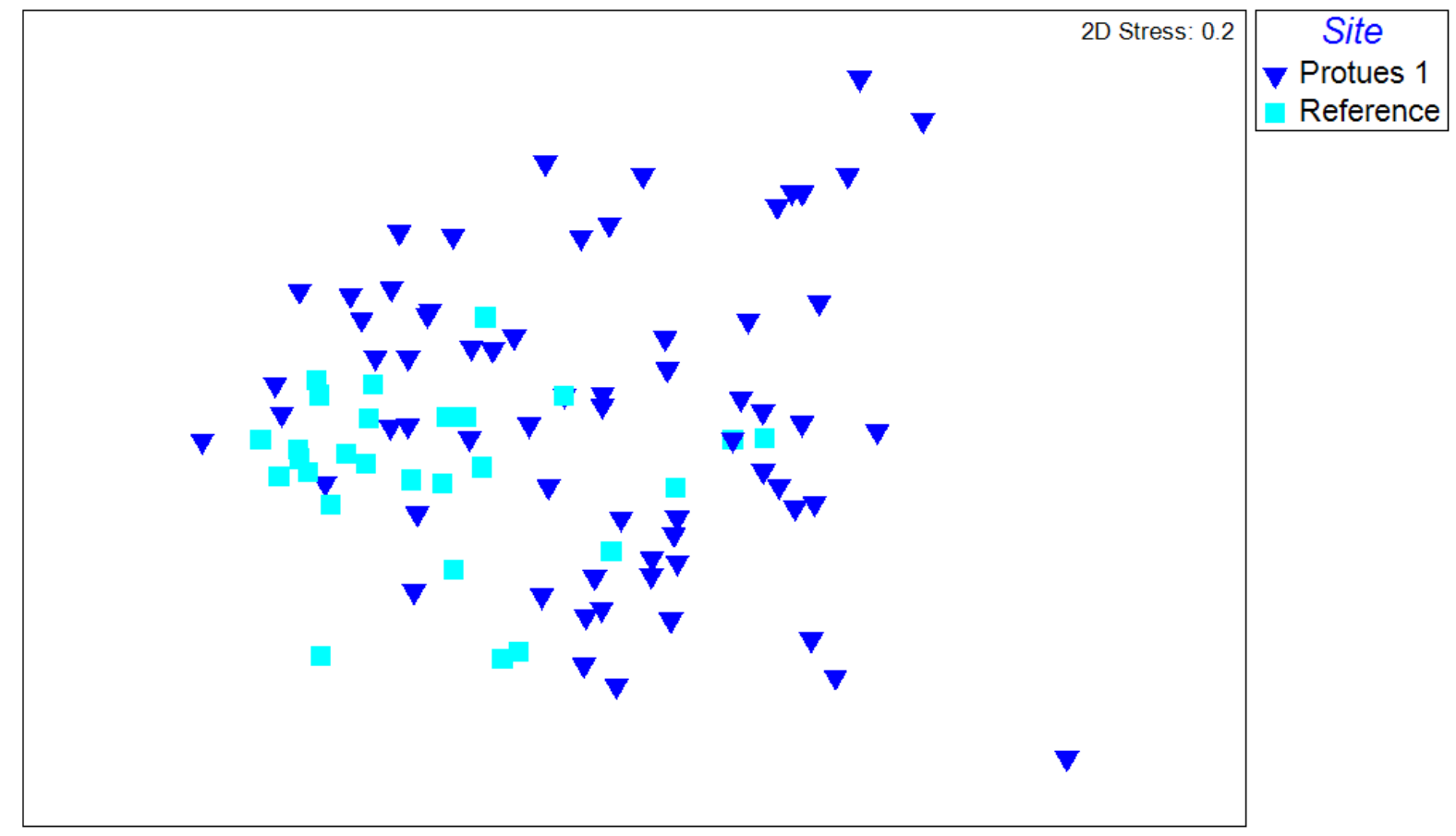

Figure S5. MDS plot of $20 \mathrm{~m}$ video segments, plotted by site. Dark blue triangles: Proteus 1; light blue squares: Reference Site.

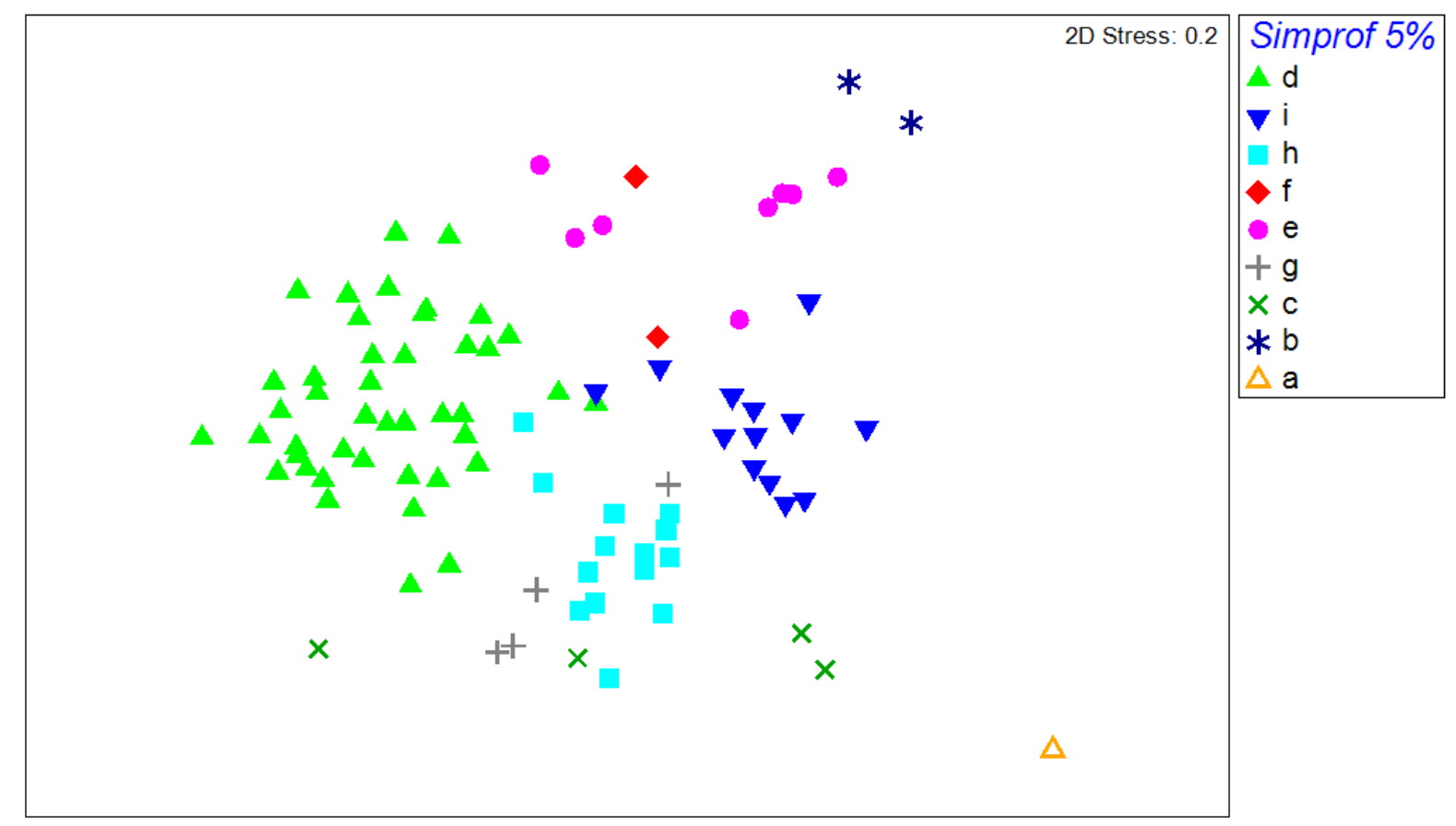

Figure S6. MDS plot of $20 \mathrm{~m}$ video segments, plotted by SIMPROF assemblage $(p=0.05)$. Each different symbol represents an assemblage type. 


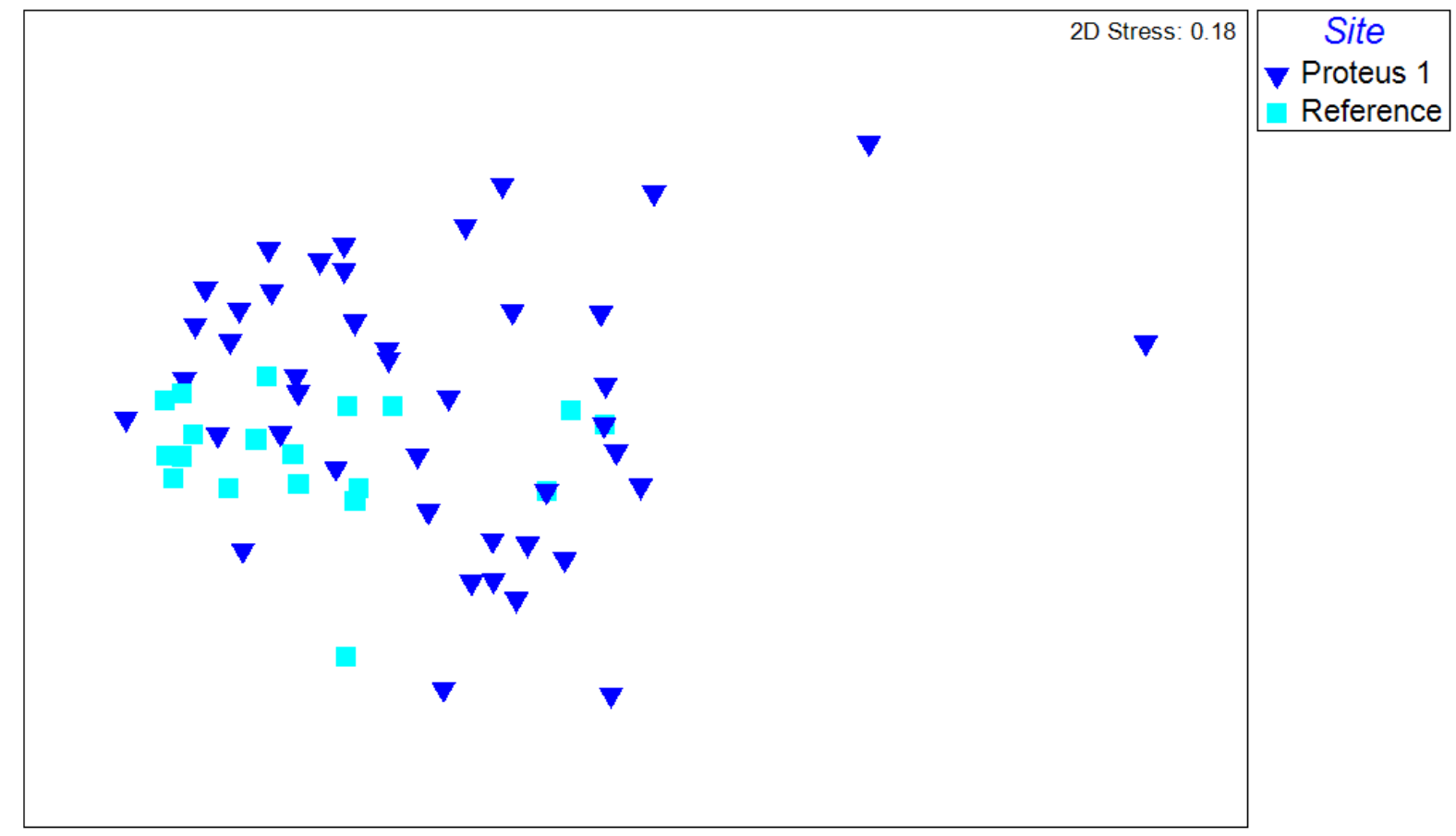

Figure S7. MDS plot of $25 \mathrm{~m}$ video segments, plotted by site. Dark blue triangles: Proteus 1; light blue squares: Reference Site.

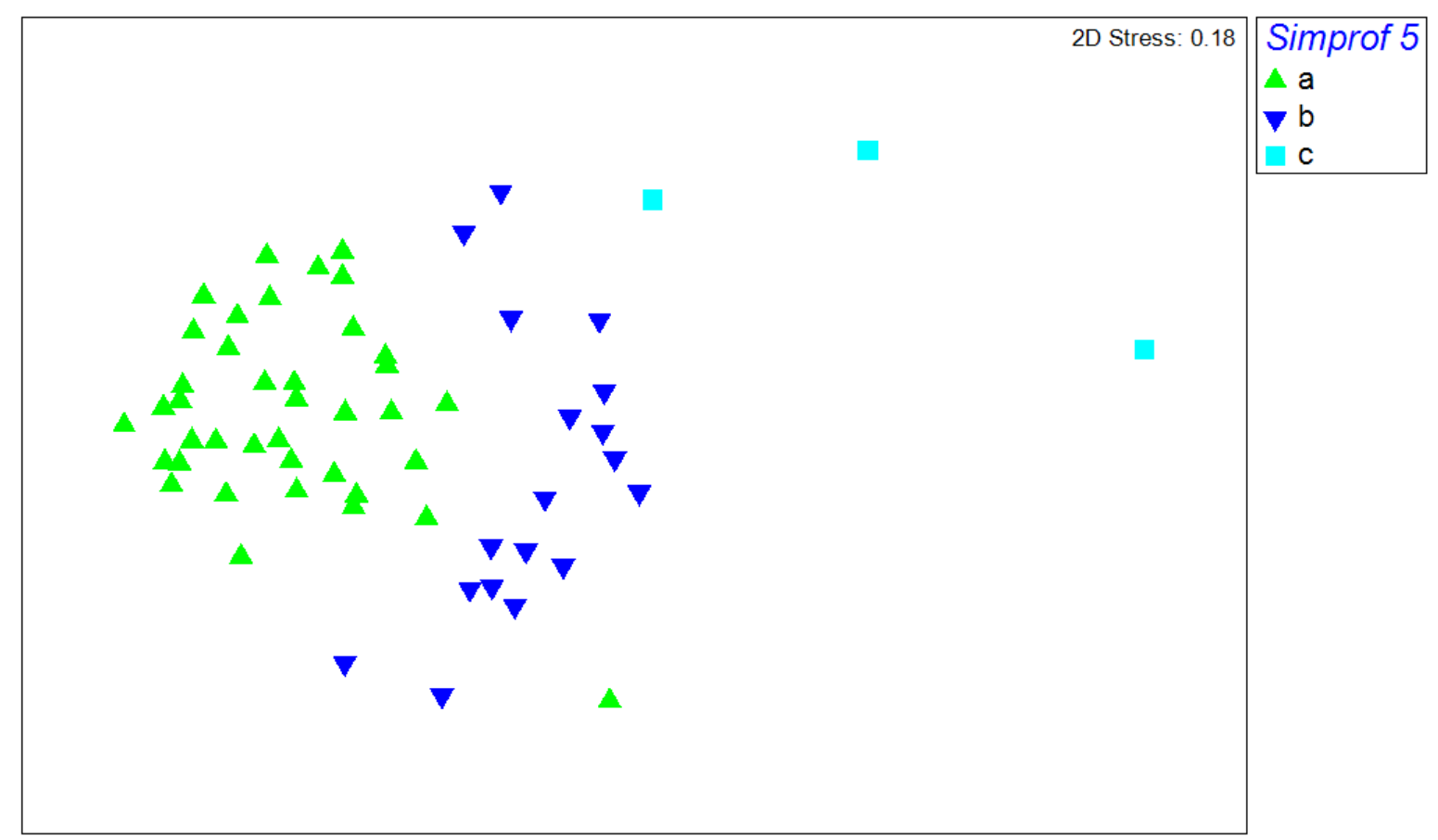

Figure S8. MDS plot of $25 \mathrm{~m}$ video segments, plotted by SIMPROF assemblage $(p=0.05)$. Each different symbol represents an assemblage type. 


\title{
CHAPTER 5. Limitations in the use of archived vent mussel samples to assess genetic connectivity amongst seafloor massive sulfide deposits: a case study with implications for environmental management
}

\begin{abstract}
Genetic connectivity studies can inform the design of mitigation strategies used in environmental management. However, the expense of developing species-specific molecular markers and collecting samples at appropriate spatial and temporal scales can be prohibitive. Using archived material and existing molecular markers may provide a costeffective way to assess population connectivity. Genetic connectivity studies are increasingly in demand in the deep sea in response to mounting anthropogenic pressures, including seafloor massive sulfide (SMS) mining. The feasibility of using archived material was assessed using the New Zealand-endemic vent mussel Gigantidas gladius, which inhabits areas licensed for the prospecting phase of SMS mining. Four molecular markers were tested, but only one (mitochondrial COI) provided suitable sequences. Of 942 specimens, only 150 individuals were informative, largely due to poor tissue quality of archived samples. Seven populations spanning the distributional range of G. gladius were assessed. The results indicate that $G$. gladius has high levels of gene flow amongst sites $10 \mathrm{~s}$ to $100 \mathrm{~s} \mathrm{~km}$ apart and limited genetic structure. Haplotypic diversity was not equally distributed amongst populations, with lower diversity for the Macauley Volcano population at the northern extent of the species distribution and greater diversity within central populations. Migrant exchange was also greatest between central populations, with one population at Rumble $\mathrm{V}$ Seamount appearing important in terms of maintaining genetic diversity within the Kermadec Volcanic Arc region. However, interpretation of the results should be viewed with caution as small sample sizes may have limited the ability to detect genetic structure. Despite these limitations, mitigation strategies that protect areas of seabed from mining activities should consider the genetic vulnerability of the population at the northern edge of the species' distribution and the significance of certain central populations.
\end{abstract}




\section{Introduction}

The deep sea is subject to an increasing number of anthropogenic pressures (RamirezLlodra et al. 2011). These pressures include deep-sea mining for resources such as cobalt-rich crusts, polymetallic nodules and seafloor massive sulfide (SMS). Of these, SMS deposits are expected to undergo exploitation before 2020 (Baker and Beaudoin 2013). SMS deposits form through hydrothermal activity and exhibit a patchy distribution along seafloor tectonic margins, with deposits occurring on average every $100 \mathrm{~km}$ along the oceanic plate boundaries (Hannington et al. 2011). Active deposits support chemosynthetic communities restricted to hydrothermally active areas; many of these hydrothermal fauna have limited distributions and are endemic to one region, such as the crab Kiwa tyleri, endemic to the East Scotia Ridge in the Southern Ocean (Marsh et al. 2012, Marsh et al. 2015) and the gastropod Ifremeria nautilei, restricted to three basins in the southwest Pacific (Bouchet and Warén 1991, Thaler et al. 2011). Such limited distributions make these species particularly vulnerable to disturbance. However there are many unknowns associated with the ecology of seabed communities found at SMS deposits, including the population connectivity of key species.

SMS mining activity is expected to remove all organisms inhabiting the area to be mined (Van Dover 2011, Boschen et al. 2013, Van Dover 2014), potentially influencing the persistence of vent species in the region. To ensure vent populations remain sufficiently connected to sustain regional genetic diversity and to facilitate any repopulation of the mine site, it is important to assess the genetic structure and connectivity of populations of species vulnerable to mining disturbance. Connectivity patterns can provide important information on the sources and sinks of genetic diversity within the region and can be used to inform decisions on suitable preservation or 'set-aside' areas to mitigate the effects of mining. For example, connectivity patterns of $I$. nautilei at SMS deposits in the Manus Basin identified the proposed set-aside site as an important source population in the region (Thaler et al. 2011), whilst in the deep sea, connectivity patterns of the quill worm Hyalinoecia longibranchiata within the New Zealand Exclusive Economic Zone (EEZ) raised questions on the suitability of existing Benthic Protected Areas (Bors et al. 2012).

To conduct genetic connectivity studies, many different marker types are available, based on an assessment of variation in allozymes, nuclear DNA, and organelle DNA, such as mitochondria (Hellberg et al. 2002, Liu and Cordes 2004, Freeland 2005). Each marker type has advantages and disadvantages, such as the relative cost, time and expertise required for development. Some markers are 'generic' and can be applied to multiple taxa. For DNA sequencing, these include the mitochondrial cytochrome $c$ oxidase subunit I 
$(C O /)$ and the nuclear internally transcribed spacer region (ITS), which are amplified with generic primers (White et al. 1990, Folmer et al. 1994). For DNA fragment analysis they include primers for amplified fragment length polymorphisms (AFLPs), randomly amplified polymorphic DNA (RAPDs) and sequence-related amplified polymorphisms (SRAPs). Other species-specific markers require more investment in development and characterization, such as microsatellites and single nucleotide polymorphisms (SNPs). Typically, suitable markers for population genetic connectivity studies must demonstrate intraspecific variation, be neutral (i.e. not subject to selection pressures), and have a known means of inheritance (Hellberg et al. 2002).

For assessments to be informative, sufficient individuals must be sampled from multiple populations spanning the geographic range of interest. However, obtaining sufficient fresh samples can be challenging, particularly within the marine environment, where the cost of sampling generally increases with depth and distance from shore. This challenge can be problematic in the deep sea, where financial and technical demands (such as vessel costs and the need for specialized sampling equipment) can inhibit collection of fresh material, restricting the spatial, and temporal coverage of samples. In the case of SMS mining, the first wave of exploitation is expected to occur within the EEZs of Pacific Island nations. Most of these nations have limited resources and the cost of collecting new samples at a range of spatial scales and developing new molecular markers could restrict the use of genetic connectivity studies. Although mining contractors would be expected to cover the cost of studies at prospective mine sites, connectivity studies outside of the mining lease area would not be sponsored. Regional-scale studies are essential for understanding the connectivity of vent organisms at meaningful biological spatial scales; cost-effective methods could enable large-scale studies to be conducted in resource-limited situations.

An alternative to obtaining fresh samples is to use archived material collected over many years and curated in national biological collections. Although this material has potential drawbacks, such as incomplete specimen records, small sample sizes and occasionally low quality DNA (Wandeler et al. 2007), it is less expensive than obtaining fresh material and could provide a collection of samples with suitable temporal and spatial coverage for genetic connectivity studies. Using generic molecular markers that can be applied to multiple taxa would overcome the expense and expertise required to develop new species-specific markers, which could be beneficial for scientists in nations where resources and expertise are limited. 
Multiple areas within the New Zealand EEZ have been licensed for the prospecting phase of SMS mining (Fig. 1, http://www.nzpam.govt.nz/cms/online-services/currentpermits/), but there is currently limited information on the population connectivity of species and assemblages which could be impacted. The mineral worth of New Zealand SMS deposits, which are rich in copper, zinc, gold and silver (de Ronde et al. 2011) is balanced by their biological value, with the deposits and the surrounding seabed supporting a wide range of benthic assemblages (Boschen et al. 2015). These assemblages include chemosynthetic species (Clark and O'Shea 2001, Rowden et al. 2003) such as the vent mussel Gigantidas gladius, which is often very abundant (Fig. 2) but is potentially vulnerable to disturbance from mining activity. G. gladius was chosen for this study because it inhabits multiple sites of active hydrothermal venting where licenses for the prospecting phase of SMS mining have been issued. As a vent obligate species endemic to the New Zealand EEZ (Von Cosel and Marshall 2003), any disturbance from mining activities could be particularly detrimental to the persistence of the species. Assessing the population genetic connectivity of species that are representative of vent systems is essential for designing management strategies to mitigate the impacts of mining on biodiversity within the Kermadec Volcanic Arc region. 


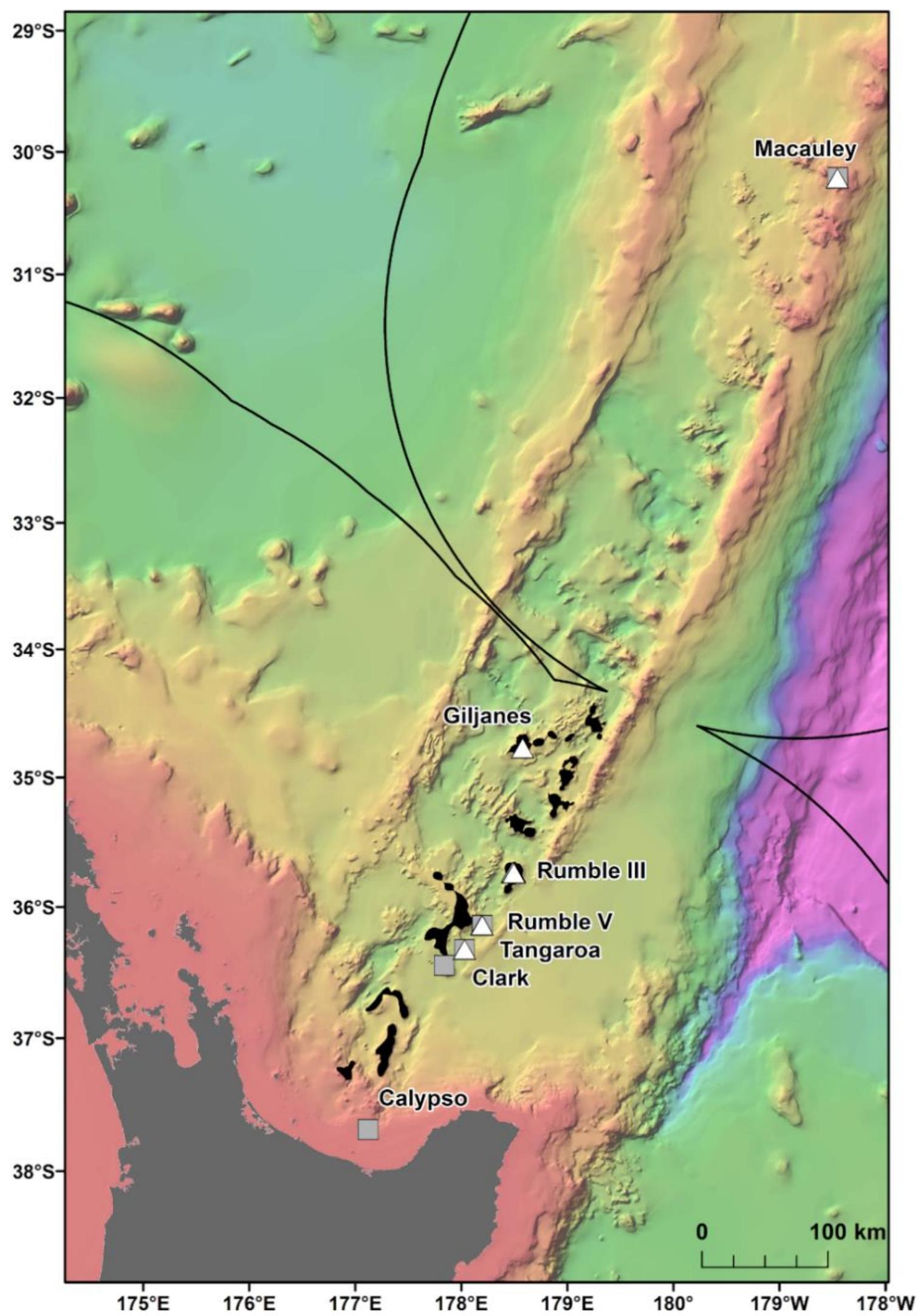

Figure 1. Gigantidas gladius sample locations along the Kermadec Volcanic Arc. Solid line indicates the New Zealand EEZ. Grey squares are samples used in this study, white triangles are excluded samples and black areas indicate where prospecting licenses have been issued for SMS mining. 


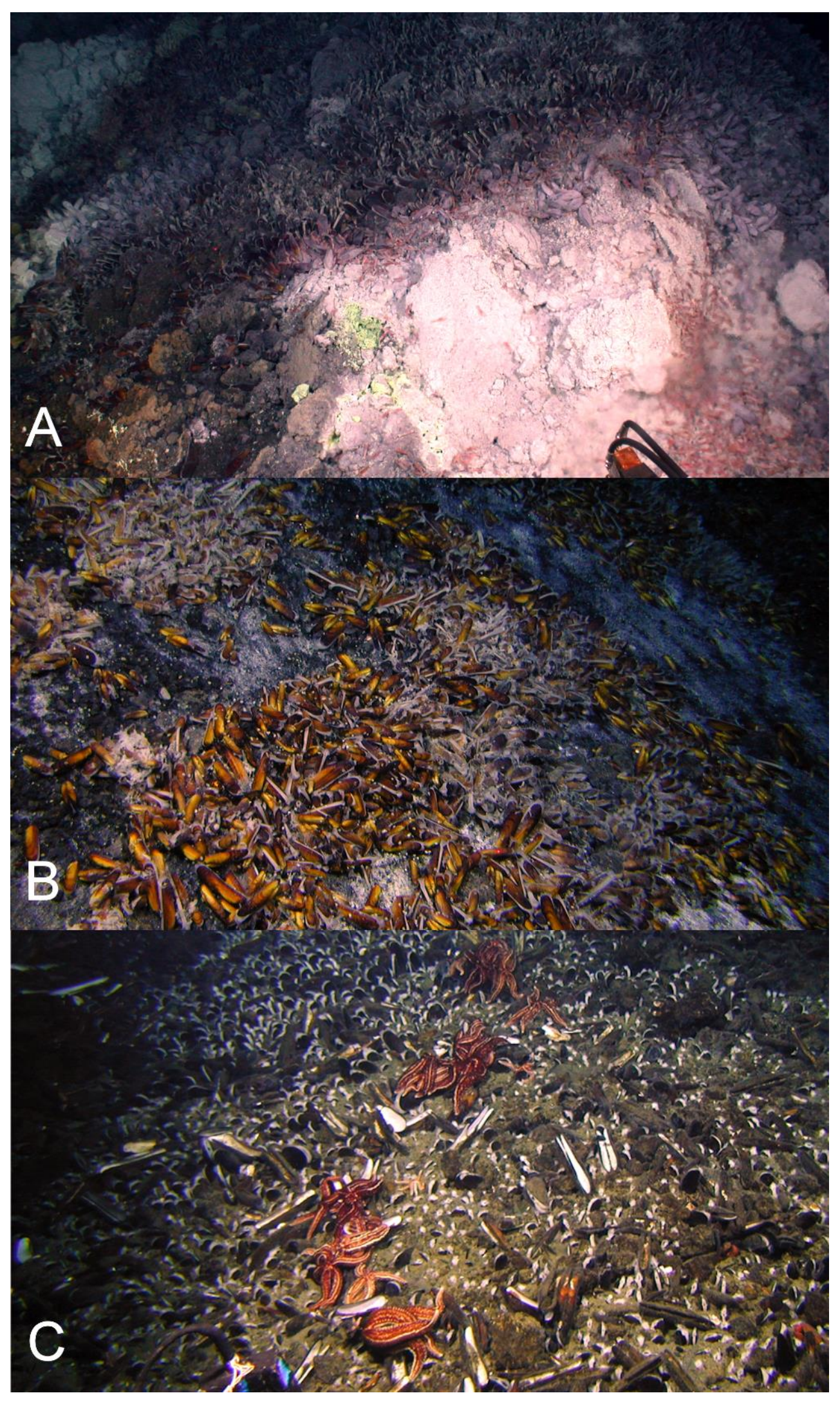

Figure 2. Gigantidas gladius adults and juveniles in situ at Rumble V Seamount, on the periphery of an active hydrothermal vent $(\mathbf{A})$, in clumps on the seabed $(\mathbf{B})$ and within the sediment, predated upon by the asteroid Sclerasterius eructans (C). Images are from the joint New Zealand-USA 2005 NOAA 'Ring of Fire Expedition'. Image credit NIWA. 


\section{Materials and Methods}

\subsection{Rationale}

This study assesses the feasibility of using generic markers and archived material in genetic connectivity studies through populations of the hydrothermal vent endemic mussel Gigantidas gladius from within the New Zealand EEZ. G. gladius was chosen for this study because it is well represented as archived material in the NIWA Invertebrate Collection (NIC) and samples span the entire known species' distribution (Fig. 1) from Macauley Volcano in the north to Calypso Vents in the south $(830 \mathrm{~km}$ distance and $\sim 7.5$ degrees of latitude), enabling the connectivity of all currently known populations to be assessed. The collections encompass more than a decade (November 2000 - October 2012) of sampling across a substantial depth range (191-884 m), enabling the investigation of connectivity over time and depth, as well as geographical space (Table 1, Table S1). Off-the-shelf extraction kits were used in the study as low-tech cost-effective options that would be suitable for use by scientists in nations where resources and expertise are limited. Generic markers were chosen as alternatives to the development of species-specific markers, enabling the feasibility of their use in low-cost connectivity studies to be assessed.

\subsection{Sampling and DNA extraction}

In total, 942 specimens of $G$. gladius were catalogued in the NIC as available for tissue sub-sampling. Where shells were available, the shell length of each individual was measured for cohort analysis. In expectation that different preservation methods and the length of time since sample collection would mean not all individuals had tissue of sufficient quality for genetic analysis (Wandeler et al. 2007), an initial analysis (DNA extraction, PCR and sequencing) of six individuals per catalogue lot number (sample) from the NIC was used to screen collections of specimens and identify samples with DNA of sufficient quality and quantity for analysis. In total, 792 individuals (84\% of those catalogued as available) were unsuitable for genetic analysis (Table S1). These included 53 paratypes, 75 preserved in formalin, approximately 20 that were too damaged to differentiate individually, 36 too small to dissect successfully, 669 with DNA of too low quality to sequence, as determined by NanoDrop ${ }^{\mathrm{TM}}$ ND-1000 (Thermo Scientific) quantification of DNA concentrations and the A260/A280 ratios, and 16 with sequences too poor to be used in analysis. As valuable taxonomic vouchers, the paratypes were unavailable to the study. A subset of formalin-preserved individuals was initially trialled but DNA extraction using a Genomic DNA Mini Kit (Tissue) (Geneaid Biotech Ltd., Taiwan) failed to obtain usable sequences, so formalin samples were excluded from further genetic 
analysis. Individuals that were too small to dissect (approx. $5 \mathrm{~mm}$ long) had insufficient DNA for successful extraction and so were discarded. As a result, only 150 sequences (16\% of the available individuals) from seven locations along the Kermadec Volcanic Arc were available for genetic analysis (Table 1). The individuals used for analysis were collected on multiple research cruises using different sampling gear between January 2000 and October 2012 (Table 1). All of the 150 sequences were from individuals fixed and stored in ethanol. A population consisted of all the individuals collected from a discrete sampling location (Table 1) and the seven populations used for analysis span the known distributional range of G. gladius; population 1, Macauley Volcano; populations 2, 3 and 4, Rumble V Seamount; population 5, Tangaroa Seamount; population 6, Clark Seamount; and population 7, Calypso Vents (Fig. 1).

DNA was extracted using a Genomic DNA Mini Kit (Tissue) (Geneaid Biotech Ltd., Taiwan) from mantle edge tissue $(\sim 5 \mathrm{~mm})$. Extraction followed the manufacturer's instructions, except that the Proteinase $\mathrm{K}$ step was increased from $30 \mathrm{~min}$ to 3 hours and the GBT buffer step was increased from 20 min to 1 hour to increase DNA yield, thus obtaining DNA of sufficient quantity and quality for sequencing. Two alternative DNA extraction kits (ISOLATE II Genomic DNA Kit, Bioline; DNeasy Blood \& Tissue Kit, Qiagen) were trialled but as the DNA yield and quality, as measured by NanoDrop ${ }^{\mathrm{TM}}$ quantification of DNA concentrations and the A260/A280 ratios, was similar amongst kits, the Genomic DNA Mini Kit was selected for all further extractions as the most cost effective option.

\subsection{DNA sequencing - PCR conditions and primers}

Four DNA regions were investigated; mitochondrial $\mathrm{CO}$, mitochondrial $\mathrm{NADH4}$, nuclear ITS and nuclear 28S. Primers used in this study were predominantly 'generic', being both widely available and applicable to multiple taxa. Primers and PCR cycle regimes are detailed in Table 2. PCRs were undertaken using a MultiGeneTM gradient thermocycler (Labnet International Inc., USA). The PCR mixture consisted of $2 \mu \mathrm{l}$ of 20-50 ng/ $\mu$ I DNA, $0.45 \mu \mathrm{l}$ each of $10 \mu \mathrm{M}$ forward and reverse primers (Integrated DNA Technologies, Singapore), $0.10 \mu \mathrm{l}$ of $5.5 \mathrm{U} \mu \mathrm{l}-1$ Fisher BioReagentsTM Taq DNA polymerase (Thermo Fisher Scientific Inc., USA), $1.50 \mu \mathrm{l}$ of the supplied 10x buffer, $0.6 \mu \mathrm{l} 5 \mathrm{mM}$ dNTP, $1.2 \mu \mathrm{l}$ of $25 \mathrm{mM} \mathrm{MgCl} 2$ and $0.60 \mu \mathrm{l} 10 \mathrm{mg} \mathrm{ml}-1$ bovine serum albumin (BSA). Total reaction volume was made up to $15 \mu \mathrm{l}$ using $8.10 \mu \mathrm{l}$ of double distilled $\mathrm{H}_{2} \mathrm{O}$. PCR products were visualized on a $1 \%$ agarose gel prepared with $0.5 \mathrm{~g}$ agarose and $50 \mathrm{ml} 0.5 \mathrm{x}$ TBE buffer. Gel band size was calculated using the molecular ladder Hyperladder ${ }^{\mathrm{TM}} 100$ bp (Bioline, UK). PCR products were loaded onto the gel using $5 x$ loading buffer (Bioline, UK). Gels were imaged 
using an Essential V2 UV transilluminator (Uvitec, Cambridge). All PCR products were cleaned prior to sequencing using ExOSAP-IT® (Affymetrix, USA) following manufacturer's instructions, except that only half the recommended volume of ExOSAP-IT® was required to produce sufficiently clean PCR products. Sanger ABI sequencing of cleaned PCR products was undertaken by Massey Genome Service (Massey University, New Zealand) on an ABI 3730 (Applied Biosystems Inc., USA). All individuals were sequenced using the forward primer. For quality control purposes, mussel-specific haplotype designations were checked by repeat sequencing of 12 individuals. 
Table 1. Gigantidas gladius specimens used for analysis from the NIWA Invertebrate Collection. For latitude and longitude, '-' refers to decimal degrees South and West respectively.

\begin{tabular}{|l|l|l|l|l|l|l|l|l|l|l|}
\hline Population & $\begin{array}{l}\text { Catalogue } \\
\text { Number }\end{array}$ & Voyage & Station \# & Date & $\begin{array}{l}\text { Place } \\
\text { name }\end{array}$ & Latitude & Longitude & $\begin{array}{l}\text { Depth } \\
\text { range } \\
\text { (m) }\end{array}$ & $\begin{array}{l}\text { Gear } \\
\text { sequences }\end{array}$ \\
\hline 1 & 87207 & TAN0206 & DR02/11 & $10 / 05 / 2002$ & $\begin{array}{l}\text { Macauley } \\
\text { Volcano }\end{array}$ & -30.2110 & -178.4492 & 230 & Rock dredge & 16 \\
\hline 2 & 32444 & KOK0506 & KOK0506/15 & $30 / 04 / 2005$ & $\begin{array}{l}\text { Rumble V } \\
\text { Seamount } \\
\text { Rumble V } \\
\text { Seamount }\end{array}$ & -36.1394 & 178.1957 & 379 & Submersible & 5 \\
\hline 3 & 19349 & KOK0505 & KOK0505/56 & $21 / 04 / 2005$ & 178.1982 & 486 & Submersible & 13 \\
\hline 3 & 32805 & KOK0505 & KOK0505/56 & $21 / 04 / 2005$ & $\begin{array}{l}\text { Rumble V } \\
\text { Seamount }\end{array}$ & -36.1407 & 178.1982 & 486 & Submersible & 2 \\
\hline \multirow{\infty}{\infty}{} & 84453 & KOK0505 & KOK0505/56 & $21 / 04 / 2005$ & $\begin{array}{l}\text { Rumble V } \\
\text { Seamount }\end{array}$ & -36.1407 & 178.1982 & 486 & Submersible & 16 \\
\hline 4 & 86447 & TAN1213 & TAN1213/59 & $26 / 10 / 2012$ & $\begin{array}{l}\text { Rumble V } \\
\text { Seamount }\end{array}$ & -36.1415 & 178.1997 & $405-408$ & Epibenthic sled & 23 \\
\hline 4 & 86448 & TAN1213 & TAN1213/59 & $26 / 10 / 2012$ & $\begin{array}{l}\text { Rumble V } \\
\text { Seamount }\end{array}$ & -36.1415 & 178.1997 & $405-408$ & Epibenthic sled & 8 \\
\hline 4 & 86462 & TAN1213 & TAN1213/59 & $26 / 10 / 2012$ & $\begin{array}{l}\text { Rumble V } \\
\text { Seamount }\end{array}$ & -36.1415 & 178.1997 & $405-408$ & Epibenthic sled & 34 \\
\hline 5 & 82111 & TAN1206 & TAN1206/17 & $16 / 04 / 2012$ & $\begin{array}{l}\text { Tangaroa } \\
\text { Seamount }\end{array}$ & -36.3247 & 178.0308 & $667-695$ & Epibenthic sled & 12 \\
\hline 5 & 82112 & TAN1206 & TAN1206/17 & $16 / 04 / 2012$ & $\begin{array}{l}\text { Tangaroa } \\
\text { Seamount }\end{array}$ & -36.3247 & 178.0308 & $667-695$ & Epibenthic sled & 18 \\
\hline 6 & 32448 & KOK0506 & KOK0506/4 & $28 / 04 / 2005$ & $\begin{array}{l}\text { Clark } \\
\text { Seamount }\end{array}$ & -36.4467 & 177.8417 & 884 & Submersible \\
\hline 7 & 32220 & SO192-2 & SO192-2/6 & $28 / 04 / 2007$ & $\begin{array}{l}\text { Calypso } \\
\text { Vents }\end{array}$ & -37.6882 & 177.1227 & 191 & $\begin{array}{l}\text { Remotely } \\
\text { Operated Vehicle }\end{array}$ & 1 \\
\hline
\end{tabular}


Table 2. Primers and PCR cycle regimes.

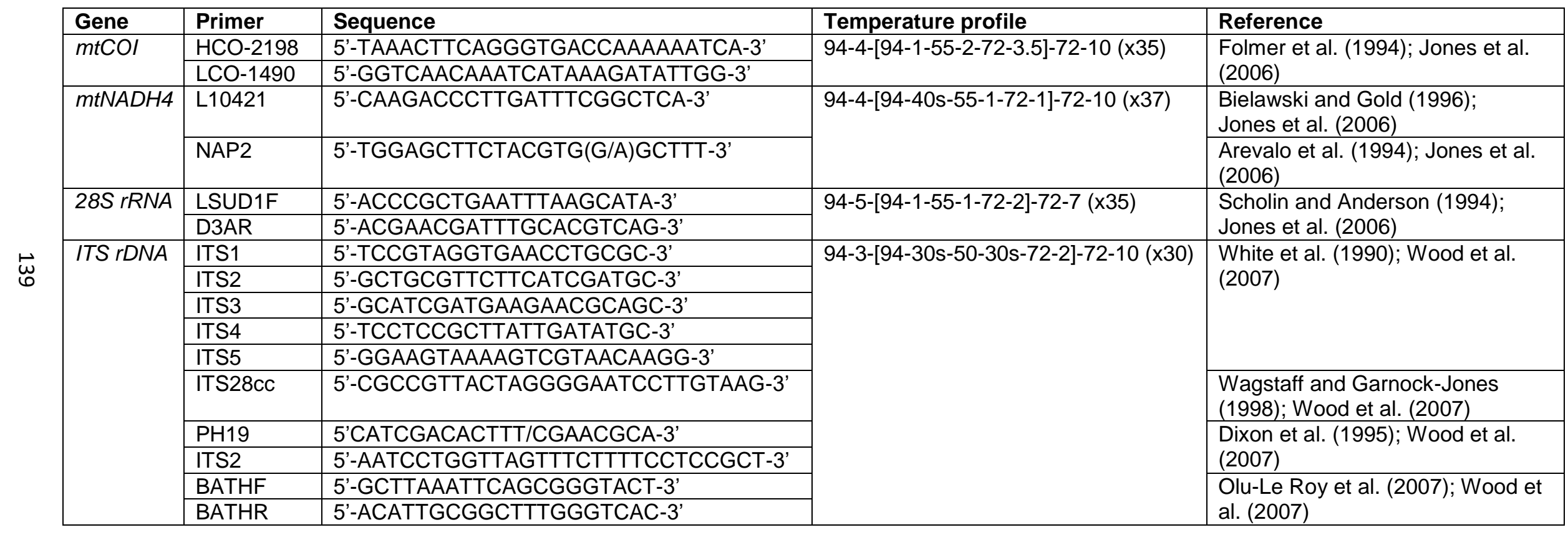




\subsection{Data analysis}

Sequences were aligned and edited using Geneious 6.06 software (http://www.geneious.com/) with default settings for Geneious alignment; 65\% similarity (5.0/-4.0) cost matrix, gap open penalty 12 , gap extension penalty 3 , global alignment with free end gaps. Sequence ends were trimmed to obtain sequences of $586 \mathrm{bp}$ length and miscalls were manually replaced by visually assessing peak height; ambiguous bases were replaced with the base that had the highest peak at that site. The base(s) characterizing each haplotype were checked for adequate peak height and differentiation. Haplotype validity was further checked by pairwise alignment in Geneious of the 12 duplicate sequences.

The Geneious alignment in fasta format was used as an input file for FaBox (Villesen 2007). Basic haplotypic diversity statistics for the seven populations were generated in FaBox and the project file was used as the input file for analyses using Arlequin v3.5.1.2 (Excoffier et al. 2005). To assess whether sufficient individuals were sampled to capture the haplotypic diversity of the seven populations, rarefaction curves (per population and overall) were calculated in RarefactWin (http://strata.uga.edu/software/Software.html) and plotted in Excel 2013. To visualize the connectivity of and relationships amongst haplotypes, a minimum spanning haplotype network (Bandelt et al. 1999) was generated using Popart (http://popart.otago.ac.nz), with the default epsilon value (0). The network was generated using the fasta file of the Geneious alignment, converted to nex format in DnaSPv5 (Librado and Rozas 2009). Haplotype pie charts for each population were generated in Excel 2013 and plotted over a base map in ArcMap 10.1 (Environmental Systems Research Institute, USA) to display the haplotype distribution along the Kermadec Volcanic Arc. Analysis of Molecular variance (AMOVA) tests (Excoffier et al. 1992) in Arlequin were used to investigate the effect of metapopulation (all 7 populations combined), location (North, Central or South Kermadec Volcanic Arc), year, and depth of collection on genetic connectivity amongst populations (Table 3). AMOVAs were performed using standard AMOVA computations (haplotypic format) and conventional F-statistics ( $\Phi$-statistics for DNA sequence data). Additional AMOVAs were conducted on population 4 (Station 59, Rumble V Seamount), population 5 (Station 17, Tangaroa Seamount) and combined population 4 and 5 to investigate the effect of age cohort (as determined by individual shell length) on genetic connectivity amongst individuals sampled from neighbouring seamounts in the same year. To assess the effect of geographic distance on genetic connectivity, a Mantel test (Mantel 1967, Smouse et. al 1986) was performed in Arlequin. The Mantel test was performed with 1000 
permutations, the distance matrix was a log of the distance between populations in meters and the ФST matrix was based on slatkinlinearfst (Slatkin 1995). The number of migrants between populations per generation was calculated using the formula $M=(1-\Phi S T) /(2 *$ ФST) (Excoffier et al. 2005).

The mitochondrial haplotype sequences from this study were submitted to GenBank. The accession numbers are as following: KU180249, KU180250, KU180251, KU180252, KU180253, KU180254, KU180255, KU180256, KU180257, KU180258, KU180259, KU180260, KU180261, KU180262, KU180263, KU180264, KU180265, KU180266, KU180267, KU180268, KU180269, KU180270, KU180271, KU180272, KU180273, KU180274, KU180275, KU180276, KU180277, KU180278, KU180279, KU180280, KU180281, KU180282, KU180283.

Table 3. Group structure used for AMOVA tests. Numbers in brackets relate to the group number that populations were assigned to for each AMOVA analysis. KVAN: Kermadec Volcanic Arc North, KVAC: Kermadec Volcanic Arc Central, KVAS: Kermadec Volcanic Arc South. Pop 6 and7 were too small ( $n=2$ and $n=1$, respectively) to be included in AMOVA analyses.

\begin{tabular}{|l|l|l|l|}
\hline Population & Region & Year & Depth \\
\hline Pop 1 (1) & KVAN (1) & $2002(1)$ & Shallow (1) \\
\hline Pop 2 (1) & KVAC (2) & $2005(2)$ & Medium (2) \\
\hline Pop 3 (1) & KVAC (2) & $2005(2)$ & Medium (2) \\
\hline Pop 4 (1) & KVAC (2) & $2012(3)$ & Medium (2) \\
\hline Pop 5 (1) & KVAC (2) & $2012(3)$ & Deep (3) \\
\hline Pop 6 & KVAC & 2005 & Deep \\
\hline Pop 7 & KVAS & 2007 & Shallow \\
\hline
\end{tabular}

\section{Results}

\subsection{Use of generic primers}

PCR amplification of the NADH4 gene was unsuccessful using the selected primers; no bands (DNA products from the PCR) were visible on a $1 \%$ agarose gel. For the $28 S$ gene, the region was successfully amplified but there was no sequence variation amongst the 20 test individuals, so the gene was not investigated further. The multiple primer pairs used to amplify the ITS region produced sequences of the expected length but the presence of multiple base peaks suggested that duplicate copies of ITS were present within the same individual. One short (200 bp) region of single copy ITS2 produced clean and usable sequences, but there was no variation within the region amongst the 20 test individuals and so the region was not used for analysis. The universal primers used for $\mathrm{CO}$ resulted in 586 bp of good quality sequence for 150 G. gladius individuals distributed across the 
seven populations. All analyses of population genetic connectivity were performed using these $\mathrm{CO}$ sequences.

\subsection{Quality control tests}

To check the observed high levels of haplotypic diversity, 12 individuals were repeat sequenced. Pairwise alignment of duplicate sequences demonstrated $100 \%$ identity of mussel-specific DNA sequences after ambiguous bases were resolved, indicating that the observed haplotypic diversity was real and not a PCR or sequencing artefact. Repeat sequencing indicated that sequencing using the forward primer was sufficient to consistently produce accurate sequences of the appropriate length and that duplicate sequencing using the reverse primer was not necessary.

Rarefaction curves of haplotypic diversity were used to assess sampling effort to capture genetic diversity within populations. Curves for all individuals regardless of population (Fig. 3A) did not approach an asymptote, suggesting that insufficient individuals were sampled to capture the full haplotypic diversity of the metapopulation. Similarly, rarefaction curves for individual populations (Fig. 3B) also did not approach an asymptote. The rarefaction curves for populations 4 and 5 had similar gradients, but the slope for population 3 was steeper and for populations 1 and 2 was shallower than for the other populations. Populations 6 and 7 were too small for rarefaction analysis.

\subsection{Patterns in genetic diversity}

In total, 35 mitochondrial DNA COI haplotypes were identified from the 150 individuals across seven populations. This diversity was not evenly distributed (Table 4), with population 4 having the greatest number of haplotypes, populations 3 and 5 exhibiting intermediate diversity and populations 1,2, 6 and 7 having the smallest number of haplotypes. In general, COI haplotypic diversity was a function of population sample size, with the notable exception of population 1. Haplotypic diversity was higher in the central part of the Kermadec Volcanic Arc (populations 3, 4 and 5; 13, 19 and 10 haplotypes, respectively) and lower at the northern and southern ends of the sampling range (population 1 and population 5; 2 and 1 haplotypes, respectively) (Fig. 4).

Many haplotypes were only observed in one individual ( $n=29$ or $83 \%$ of all haplotypes) with the occurrence of these 'private' haplotypes increasing with sample size, again with the exception of population 1 (Fig. 5). Six haplotypes were shared amongst populations; haplotypes 3 and 5 were found in all populations, haplotypes 1 and 11 were found in populations 3 and 4, and haplotypes 12 and 20 were found in populations 4 and 5 
(Fig. 5). The majority of haplotypes in the network are the result of a single mutational step from the most common haplotype, haplotype 3, or in some cases haplotype 5. Five intermediate haplotypes (represented by a double mutational step) were not sampled from the metapopulation.

Table 4. Basic population statistics summary information.

\begin{tabular}{|l|c|c|}
\hline Population & No. of COI sequences & No. of COI haplotypes \\
\hline 1- Macauley Volcano & 16 & 2 \\
\hline 2- Rumble V Seamount & 5 & 2 \\
\hline 3- Rumble V Seamount & 31 & 13 \\
\hline 4- Rumble V Seamount & 65 & 19 \\
\hline 5- Tangaroa Seamount & 30 & 10 \\
\hline 6- Clark Seamount & 2 & 1 \\
\hline 7- Calypso Vents & 1 & 1 \\
\hline
\end{tabular}

There has been extensive migrant exchange amongst populations along the Kermadec Volcanic Arc. The number of migrants per generation between pairs of populations (Table 5) was greatest between populations 2 and 3 (both on Rumble $\mathrm{V}$ Seamount) and also high between populations 3 and 5 and populations 3 and 6 . Populations 5 and 6 occurred on Tangaroa and Clark Seamounts respectively, the two seamounts closest to population 3, on Rumble V. Each population exchanged migrants with at least one other population, with population 3 the only population to exchange migrants with all other populations.

There was limited genetic structure amongst populations. The AMOVA test of metapopulation identified significant haplotypic variation amongst populations (Table 6a), with pairwise testing between populations identifying population 1 (on Macauley Volcano, the most isolated seamount) as being different from populations 3 and 5 . Populations 3 and 4 (both on Rumble $\mathrm{V}$ Seamount) were also significantly different from each other (Table 6b).

\subsection{Factors influencing genetic diversity}

There was no effect of geographical distance on genetic differentiation amongst the five populations (Mantel test results, $p=0.446)$. Small samples sizes at population 6 and $7(\mathrm{n}$ $=2$ and $n=1$, respectively) meant that these populations were excluded from AMOVA tests. These tests demonstrated there was no significant influence of location, year sampled or depth sampled on genetic structure. Focused AMOVA tests of the effect of cohort (shell length) within populations 4, 5 and 4 and 5 combined revealed no effect of individual size on genetic connectivity between populations. 
Table 5. The number of migrants per generation between pairs of populations.

\begin{tabular}{|l|c|c|c|c|c|c|c|}
\hline Population & Pop 1 & Pop 2 & Pop 3 & Pop 4 & Pop 5 & Pop 6 & Pop 7 \\
\hline Pop 1 & - & & & & & & \\
\hline Pop 2 & 0 & - & & & & & \\
\hline Pop 3 & 2.0 & 88.2 & - & & & & \\
\hline Pop 4 & 9.6 & 0 & 9.4 & - & & & \\
\hline Pop 5 & 5.5 & 0 & 24.3 & 0 & - & & \\
\hline Pop 6 & 0 & 0 & 33.2 & 0 & 0 & - & \\
\hline Pop 7 & 0.1 & 0.3 & 2.1 & 0.7 & 0.9 & 0 & - \\
\hline
\end{tabular}

Table 6a. Results for AMOVA grouped as metapopulation.

\begin{tabular}{|l|l|l|l|l|l|}
\hline $\begin{array}{l}\text { Source of } \\
\text { variation }\end{array}$ & d.f. & $\begin{array}{l}\text { Sum of } \\
\text { squares }\end{array}$ & $\begin{array}{l}\text { Variance } \\
\text { component }\end{array}$ & P-value & $\begin{array}{l}\text { Percentage of } \\
\text { variation }\end{array}$ \\
\hline $\begin{array}{l}\text { Amongst } \\
\text { populations }\end{array}$ & 4 & 2.317 & $0.011 \mathrm{Va}$ & $0.016 \pm 0.004$ & 3.63 \\
\hline $\begin{array}{l}\text { Within } \\
\text { populations }\end{array}$ & 142 & 41.622 & $0.293 \mathrm{Vb}$ & & 96.37 \\
\hline Total & 146 & 43.939 & 0.304 & & \\
\hline
\end{tabular}

Table 6b. Pairwise testing between populations. Red: significant $P$-value (5\%). Top section of matrix, P-values; bottom of matrix, $\Phi_{\mathrm{ST}}$.

\begin{tabular}{|c|c|c|c|c|c|c|}
\hline & \multicolumn{5}{|c|}{ Population $P$-value (5 \%) } \\
\hline & & 1 & 2 & 3 & 4 & 5 \\
\hline \multirow{5}{*}{ 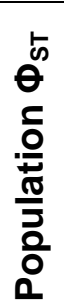 } & 1 & - & $0.447 \pm 0.017$ & $0.000 \pm 0.000$ & $0.066 \pm 0.007$ & $0.044 \pm 0.006$ \\
\hline & 2 & -0.029 & - & $0.523 \pm 0.019$ & $0.999 \pm 0.001$ & $0.999 \pm 0.001$ \\
\hline & 3 & 0.199 & 0.006 & - & $0.017 \pm 0.004$ & $0.118 \pm 0.011$ \\
\hline & 4 & 0.050 & -0.079 & 0.051 & - & $0.883 \pm 0.011$ \\
\hline & 5 & 0.083 & -0.078 & 0.020 & -0.012 & - \\
\hline
\end{tabular}




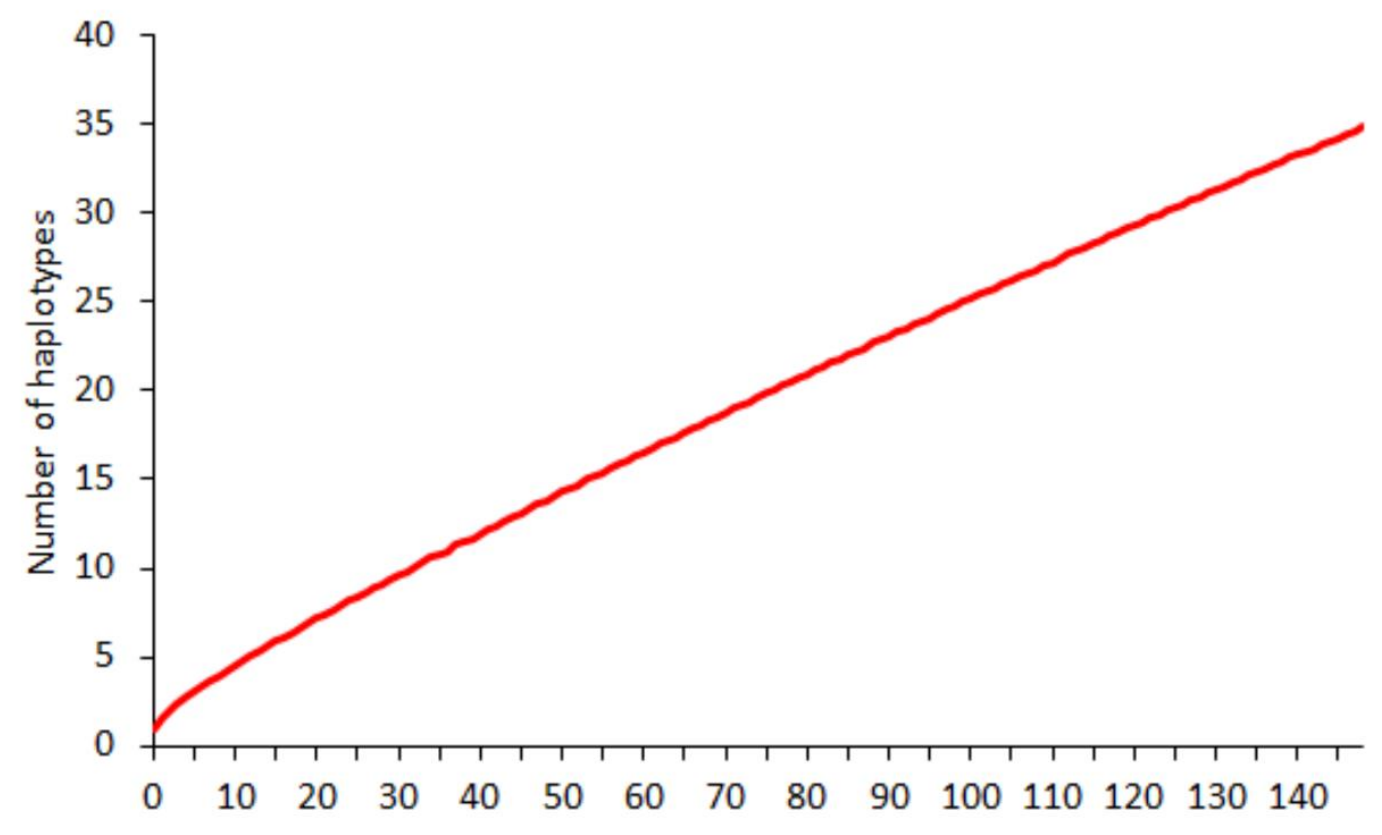

A Number of individuals

-All populations

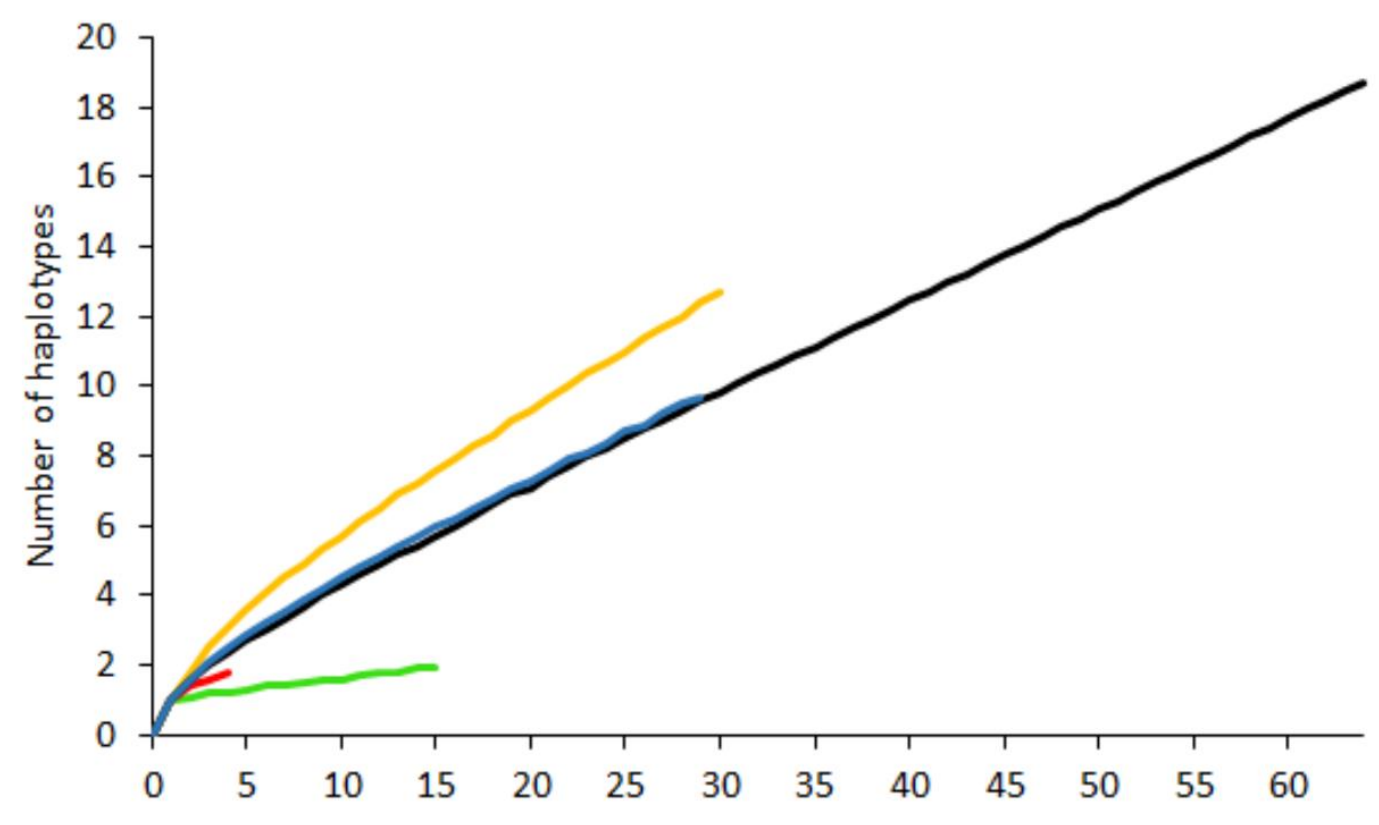

B Number of individuals - Pop1 - Pop2 - Pop3 -Pop4 - Pop5

Figure 3. Rarefaction curves for haplotype diversity for all Gigantidas gladius individuals (A) and per population (B); populations 6 and 7 were too small for rarefaction analysis. 


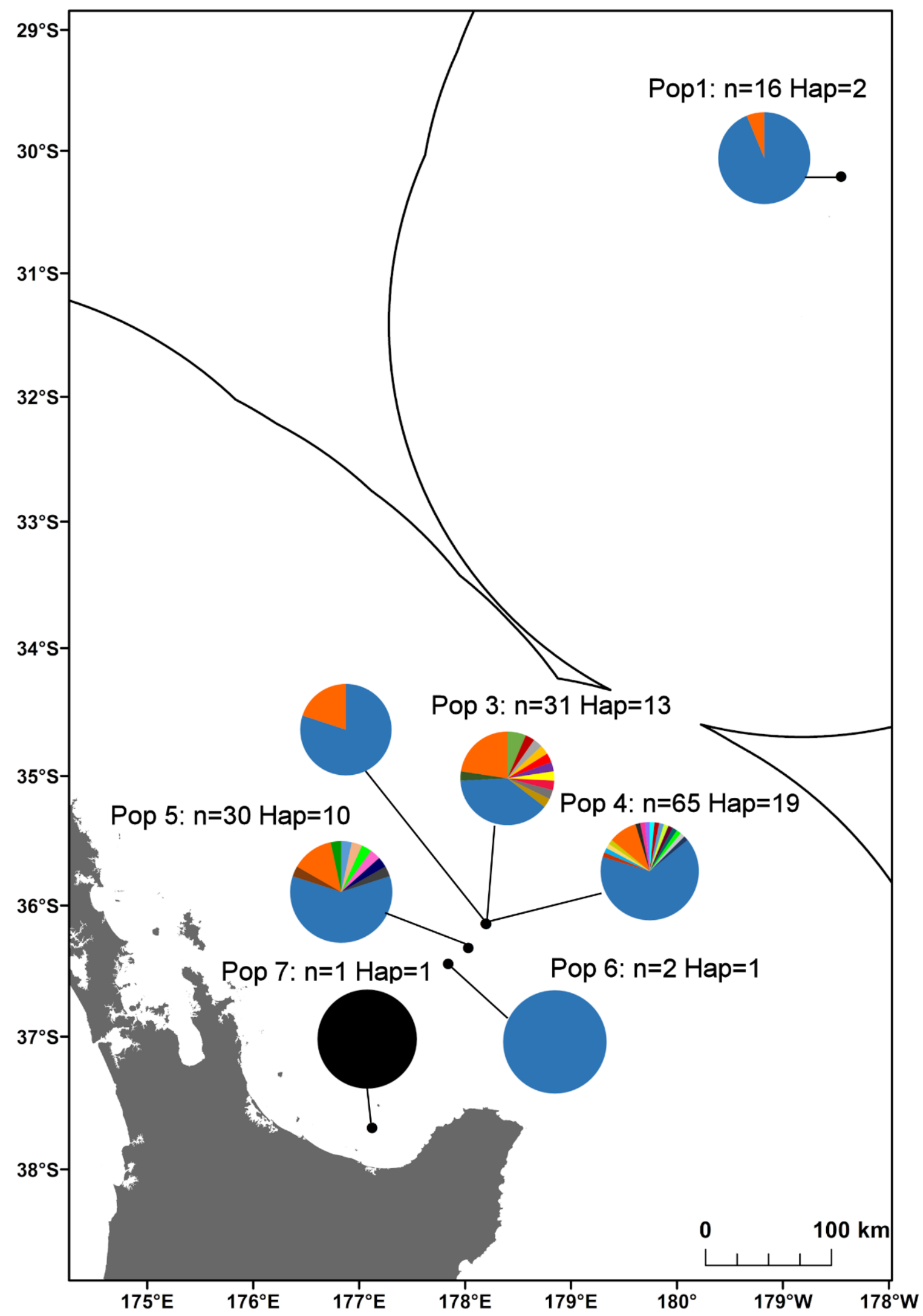

Figure 4. Haplotype diversity along the Kermadec Volcanic Arc for the seven populations of Gigantidas gladius. Each haplotype is represented by a different coloured slice of the pie chart. ' $n$ ' is the number of individuals sequenced per population, 'Hap' is the number of haplotypes. 


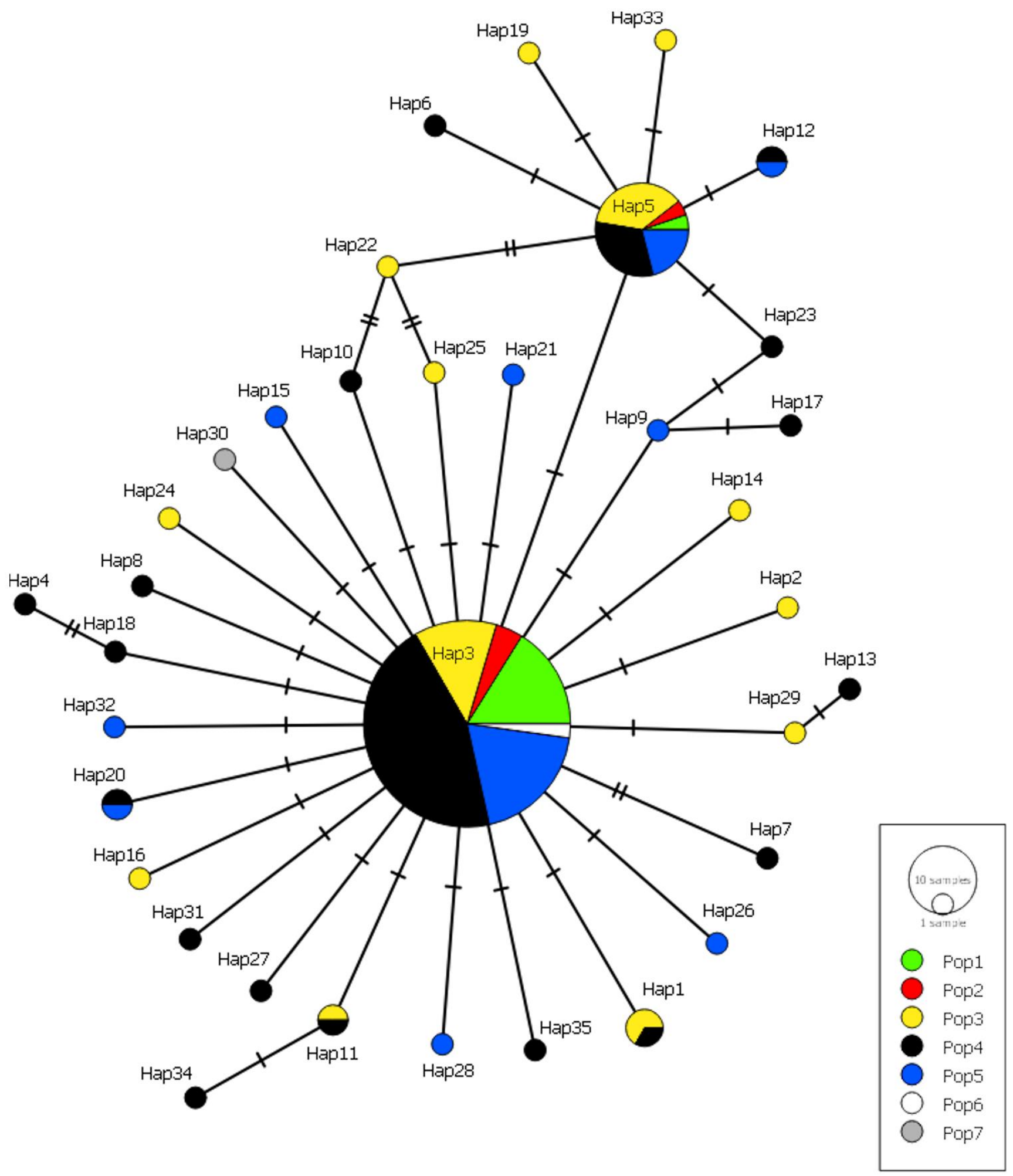

Figure 5. Minimum-spanning haplotype network for all Gigantidas gladius individuals from the seven populations. Circle size is proportional to the number of individuals with that haplotype, lines indicate relatedness of haplotypes. Line breaks indicate mutational steps in the connectivity between haplotypes. 


\section{Discussion}

The present study assessed the feasibility of using archived G. gladius samples to investigate patterns of genetic connectivity. Emphasis was placed on the use of standard, cost effective laboratory and analytical approaches, because many countries that will experience vent mining activities in the near future may not have the highly developed infrastructure or experience necessary for in depth genetic connectivity research. Below, the implications of connectivity patterns for G. gladius are considered, particularly in light of proposed SMS mining activities within the New Zealand EEZ. The practicalities and limitations of the current approach are also discussed, with particular consideration given to the ability to provide robust recommendations for environmental management.

\subsection{Population genetic connectivity of Gigantidas gladius}

Gigantidas gladius exhibited high haplotypic diversity along the Kermadec Volcanic Arc; 35 mitochondrial haplotypes within 150 individuals. This diversity was comparable to the closely related hydrothermal vent mussel Bathymodiolus thermophilus, where 10 mitochondrial haplotypes occurred within 58 individuals in the eastern Pacific (Craddock et al. 1995) and to both Bathymodiolus platifrons and Bathymodiolus japonicus off Japan, where there were 15 mitochondrial haplotypes in 40 individuals and 20 haplotypes in 41 individuals respectively (Kyuno et al. 2009, Miyazaki et al. 2013).

The star-like pattern of the haplotype network suggests that a recent expansion event has occurred, which could result from rapid colonization of new hydrothermal habitat. Hydrothermal vent systems are ephemeral, with tectonic and volcanic activity creating new habitat that is rapidly colonized by vent organisms (Lutz et al. 1994, Tunnicliffe et al. 1997). Many of the individuals used in this study were juveniles, which points to the possibility of a recent recruitment event. Star-like mitochondrial networks, implying recent population expansion, exist for many vent organisms (Vrijenhoek 2010), including B. platifrons and B. japonicus (Kyuno et al. 2009, Miyazaki et al. 2013).

There was limited genetic structure amongst $G$. gladius populations, but no significant structuring effect was evident (i.e. no effect of location/distance, depth, year or individual size). A previous study on G. gladius (then called Bathymodiolus new species NZ-1) sampled from two seamounts (Rumble V and Rumble III Seamounts; $50 \mathrm{~km}$ apart) also found no population structure using $\mathrm{CO}$, although using allozymes, pooled populations from one seamount were different to those at the other seamount (Smith et al. 2004). There was also no significant effect of individual size on genetic structure and no difference between populations on the same seamount (Smith et al. 2004). These earlier 
results agree in general with our findings using $\mathrm{CO}$ from a considerably larger collection of G. gladius samples, namely that there is high gene flow between populations along the Kermadec Volcanic Arc, although limited genetic structure was identified in the current study through pairwise testing.

A lack of geographic signal in patterns of genetic diversity was also found for $B$. thermophilus, with no evidence for barriers to gene flow across the known species' range of $2370 \mathrm{~km}$ (Craddock et al. 1995), whilst there was no effect of depth on connectivity amongst populations of the chemosynthetic seep mussel Bathymodiolus childressi (Carney et al. 2006). Another study found no differentiation amongst populations of $B$. platifrons and $B$. japonicus inhabiting both hydrothermal vent and cold seep habitats, with extensive gene flow between populations $1500 \mathrm{~km}$ apart (Kyuno et al. 2009, Miyazaki et al. 2013). Although B. platifrons and B. japonicus populations occur at both vents and seeps, which could improve dispersal through stepping-stones of reducing habitats (Smith 1989), to date $G$. gladius has only been positively identified at vent habitats. Apparent high gene flow amongst Bathymodiolus populations is thought to result from them having a planktotrophic larval stage, which is able to spend approximately a year in the plankton (Arellano and Young, 2009) and so potentially disperse over large distances. Although the reproductive mode of $G$. gladius has not been determined, it is thought to have planktotrophic larvae from the shape of the prodissoconch (Von Cosel and Marshall 2003) and so could have long-lived larvae with high dispersal potential. Such larvae could be sufficiently long-lived to populate sites as far north as Macauley Volcano, facilitating genetic exchange amongst populations.

The large number of migrants between $G$. gladius populations supports the concept of panmixia, with high levels of genetic connectivity amongst populations. However, the degree of exchange between populations is not equal, as indicated by the differences in migration rates and relative differences in haplotypic diversity. In particular, population 3 has the highest number of migrants and it also exchanges migrants with all other populations, suggesting it could be a key population for maintaining genetic diversity within the Kermadec Volcanic Arc region. The relatively lower haplotypic diversity of population 1 suggests it could be more isolated than other populations along the Arc and so is more vulnerable to disturbance. Population 1 is also genetically distinct from populations 3 and 5 (Rumble $V$ and Tangaroa Seamounts respectively), which supports this concept of relative isolation. Long-lived planktotrophic larvae should be capable of reaching population 1 at Macauley Volcano, but an absence of suitable habitat between central populations and Macauley could preclude a 'stepping-stone' mode of connectivity between central and 
northern populations. Sampling has occurred on hydrothermally active seamounts of the Arc both south and north of Macauley, but there are no records of additional G. gladius populations from sampling efforts $440 \mathrm{~km}$ to the north or between Macauley and Giljanes Seamount to the south, a distance of $580 \mathrm{~km}$ (Fig. 1). G. gladius can colonize a suite of hydrothermal habitats, including hard and soft substrata and both high and diffuse flow vent sites (Fig. 2), across a depth range of 191 - $884 \mathrm{~m}$ (Table 1, Table S1). Whilst G. gladius is thought to host chemoautotrophic bacteria (Von Cosel and Marshall 2003) it may also be an opportunistic suspension feeder in the same way as $B$. thermophilus (Page et al. 1991). By inhabiting multiple hydrothermal habitat types over a $900 \mathrm{~m}$ depth range and exhibiting a flexible feeding strategy, G. gladius increases the potential for colonization success. As a result, a lack of suitable hydrothermal habitat between Macauley and central populations seems unlikely to be the reason for the relative genetic isolation of population 1. Instead, larval dispersal distance could be limited by prevalent deep-sea currents. The East Cape Eddy may influence circulation down to $1000 \mathrm{~m}$ depth (Chiswell and Sutton 2015) and so constrain the majority of larvae within the central Kermadec Volcanic Arc. The mean flow along the Arc at $1000 \mathrm{~m}$ is thought to be southwards from Macauley towards the central populations (Chiswell et al. 2015), which could explain the lower haplotypic diversity of population 1, as larval dispersal to Macauley could be restricted to occasions when breeding events coincide with shifts in the dominant current flow. These patterns in current flow could explain the restriction of G. gladius to the Kermadec Volcanic Arc region. However, greater resolution on deep-sea currents along the Kermadec Volcanic Arc would be needed before current flow could be confirmed as the reason for the lower haplotypic diversity of population 1.

\subsection{Limitations associated with the use of archived material and generic molecular markers}

There are known drawbacks to the use of archived material in population genetic connectivity assessments, including small sample sizes and the likelihood of low quality DNA (Wandeler et al. 2007). However, archived material also has the potential to provide valuable samples. The G. gladius material archived in the NIC represents all of the available samples for this species, spanning the known distributional range of $830 \mathrm{~km}$ and nearly eight degrees of latitude, thus providing an opportunity to characterize the genetic connectivity across an entire species' range. It is also a large collection in terms of number of individuals, and is therefore an appropriate target for investigation. However, of the 942 individuals available, ultimately only 150 could be used for this study. A high rate of 
sample loss also occurred in similar studies using archived material, such as investigations using deep-sea coral tissue (Miller et al. 2010).

Small samples sizes can fail to capture the total haplotypic diversity, leave gaps in coverage across space or time, and limit the power of statistical tests (e.g. G. gladius AMOVA tests for the effect of location, depth, year, individual size) with the problem that such limitations complicate interpretation of the results. In the case of G. gladius, although panmixia is biologically feasible, the apparent lack of genetic structuring factors could also result from low statistical power to detect differences amongst populations. Although larger sample sizes would enable more robust statistical testing, it is often not possible and many deep-sea connectivity studies have to make do with far fewer specimens, in some cases less than 10 individuals per population (Miller et al. 2010, Bors et al. 2012). As such, although the small numbers of individuals used for the present study are far from ideal, they are within the range commonly seen in deep-sea studies.

The majority of specimens omitted from this study were excluded due to low quality DNA, an acknowledged risk of using archived material (Wandeler et al. 2007). Low quality DNA also has the potential to overestimate genetic diversity due to errors during amplification and sequencing (Sefc et al. 2007). As DNA quality of archived material tends to decrease with time, the risk of such errors increases with specimen age. As far as it was possible to ascertain, there was no evidence for a bias in genetic diversity associated with sample age, and hence presumptive DNA quality, of G. gladius. In particular, the highest genetic diversity was actually observed in the freshest sample (population $4: \mathrm{n}=65$, haplotype $=19$, sampled 2012), suggesting that the high haplotypic diversity observed for G. gladius is real and not due to preservation artefacts.

Four universal markers were trialled in this study, but only one was able to provide sequences suitable for population genetic connectivity assessment. This apparently low level of success highlights a problem with so-called universal markers - they are not necessarily applicable to all species or samples. Investment in further troubleshooting and testing is always possible but adds significant time and cost to a project, and also requires a higher level of technical expertise, which may not be available in all cases. For $G$. gladius, it was not feasible to troubleshoot for $N A D H 4$ or to resolve the issue of duplicate ITS sequences. Although ITS sequences have been successfully used in phylogenetic studies of other mussels, such as shallow water Perna spp. (Wood et al. 2007), studies using ITS from Bathymodiolus spp. required an additional cloning step as part of the amplification process (Jollivet et al. 1998, Olu-Le Roy et al. 2007), presumably to overcome the issue of multiple copies. Ideally, studies should incorporate both 
mitochondrial (e.g. COI) and nuclear (e.g. ITS) markers to test for patterns of genetic connectivity, but as in the case for this study, only one marker may be informative.

For G. gladius, the only successful marker was mitochondrial COI, which although commonly used to investigate interspecific genetic variation, demonstrated sufficient intraspecific variation to be used in this study. COI has been used in other deep-sea studies to assess population connectivity of the squat lobster Munida gracilis and quill worm Hyalinoecia longibranchiata (Bors et al. 2012) and the hydrothermal vent gastropod Ifremeria nautilei (Thaler et al. 2011). Using mitochondrial DNA from bivalves can be complicated by separate male and female mitochondrial genomes being transmitted independently to offspring (Fisher and Skibinski 1990). However, there is no evidence to date for gender-biased mitochondria in G. gladius' closest relatives, Bathymodiolus spp. (Won et al. 2003, Jones et al. 2006), and mitochondrial sequences are commonly used in phylogenetic studies of this group (Smith et al. 2004, Jones et al. 2006, Fontanez and Cavanaugh 2013). As such, we consider mitochondrial COI to be a suitable marker for connectivity assessment of G. gladius.

The limitations encountered in this study suggest that, using the cost-effective techniques described, archived material alone may be insufficient to assess genetic connectivity. As genetic techniques, such as formalin extraction, advance and become more affordable, samples that have historically been problematic to sequence may become available for use in connectivity studies. Although, at the present, archived material alone may be insufficient for conducting relatively low-tech, cost-effective connectivity studies, it may be used as a valuable starting point to identify spatial or temporal 'gaps' in existing material. This could permit the use of available resources to target gaps as priorities for the collection of fresh samples. Once suitable supplementary fresh material has been collected and sequences obtained, more robust environmental management recommendations can be made. A suggested work flow to obtain sequences from appropriate archived material, resulting in recommendations for management, is detailed in Fig. 6.

\subsection{Implications for the environmental management of SMS mining}

SMS mining activities have the potential to impact benthic organisms, such as G. gladius, mainly through habitat removal, altered hydrothermal flow or smothering with suspended sediment (Coffey Natural Systems 2008, Van Dover 2011, Boschen et al. 2013, Van Dover 2014). One of the proposed mitigation strategies for SMS mining is the designation of 'setaside' areas to preserve similar habitat and biodiversity within the region (International 
Seabed Authority 2010, Collins et al. 2013a, Collins et al. 2013b). This includes the conservation of genetic diversity, with patterns in population connectivity providing important information on the sources and sinks of diversity and the potential for recolonization of impacted habitat.

A number of populations of $G$. gladius inhabit areas within the New Zealand EEZ that have been licensed for the prospecting phase of SMS mining and are potentially at risk from mining activities. The results from our study suggest that although there is generally high genetic diversity within and high gene flow amongst populations for $G$. gladius, this is not distributed equally amongst populations and any set-aside area or network of set-aside sites would need to take this into consideration. For example, detrimental impacts to population 1 from mining activity could result in the loss of the northern extent of the species' distribution, contracting the known species range by 4.5 degrees of latitude. Equally, the high haplotypic diversity of population 3 and high migrant exchange between population 3 and all other populations suggests that it may be a source population. As such, population 3 is of particular importance in maintaining genetic diversity at the metapopulation level and may require protection, because disturbance to this population from mining activities has the potential to impact genetic diversity at a regional scale.

SMS mining is expected to occur on a relatively small spatial scale, with the impacts of mining predicted to be localized. For example at Solwara 1, an SMS deposit in the Manus Basin, the area of seabed licensed for exploitation is only $0.112 \mathrm{~km}^{2}$, whilst the majority of sedimentation impacts are expected to occur within $1 \mathrm{~km}$ of the discharge site (Coffey Natural Systems 2008). The nature of exploitation, removing relatively small mineral-rich patches within a wider area, reflects the distribution of deposits, which is determined by hydrothermal activity. Many organisms that rely on hydrothermal activity and so inhabit these deposits subsequently have a patchy spatial distribution, with the potential for small-scale genetic variation amongst patches that could be lost through mining activity. For example, along the East Pacific Rise, genetic differentiation was discovered between patches of the vent tubeworm Riftia pachyptila just $400 \mathrm{~m}$ apart (Shank and Halanych 2007). Although vents undergo natural habitat loss through volcanic and tectonic events, mining activities could compound this effect (Van Dover 2011), potentially enhancing the loss of localized-genetic structure. To investigate small spatial scale genetic differentiation, it is important to assess genetic connectivity not just over the 100 s or 1000 s of km that may encompass a species' range, but also at smaller spatial scales appropriate to mining disturbance. Such a nested design was used in a study of $I$. 
nautilei in the Manus Basin and demonstrated panmixia across all spatial scales, with no barriers to connectivity between individuals amongst patches within an SMS depositmound, amongst SMS mounds within a site, or amongst sites within a vent field (Thaler et al. 2011). In the one instance where archived samples of $G$ gladius occurred at multiple locations within the same seamount, Rumble V, there was evidence of genetic structure between two of the three populations. However, these populations were sampled seven years apart, so whether the difference in population structure relates to genetic patchiness within seamounts or temporal variation is unknown.

Although this study demonstrates that archived material can provide important information for environmental management, this material may be insufficient on its own for assessing the genetic connectivity of populations at SMS deposits. However, archived material can be used to inform targeted sampling (Fig. 6). Combining archived and fresh material may be a cost effective strategy to provide samples with sufficient spatial and temporal coverage for connectivity studies at SMS deposits. Although sampling is necessary to characterize and assess the suitability of potential set-aside areas, collecting from these sites also has the potential to impact resident populations. Conducting connectivity assessments with both archived and fresh material may reduce the impact of sampling at potential set-aside sites and would be a strategy in-line with guidelines for responsible sampling at hydrothermal vents (Devey 2007, InterRidge 2009).

\section{Conclusions}

The use of archived material in genetic connectivity studies is known to have limitations, many of which were encountered in this study. In particular, largely due to issues with sample preservation and DNA quality, only $16 \%$ of the catalogued G. gladius individuals yielded suitable DNA sequences for analysis. Although the connectivity results for $G$. gladius suggest high gene flow between populations with limited genetic structuring, small sample sizes reduced the power of statistical tests and ultimately mean results must be interpreted with caution. This study suggests that the use solely of archived material may be insufficient to generate robust results to inform management decisions. However, in the absence of fresh samples, using archived material can provide information that would otherwise be unavailable for making such decisions. Connectivity assessments using archived material may also be used to identify gaps in existing material, informing targeted sampling to provide the additional material required for robust statistical testing. Strategic sampling to fill gaps in archived sample coverage would be a practical option for studies where obtaining fresh samples is particularly challenging, such as within the deep sea. 
Establishing open-access reference collections for deep-sea samples, as well as the development of mechanisms whereby global genetic expertise can utilize such samples, would further facilitate the use of archived material in connectivity studies. Maximizing the use of archived material would also serve to reduce the expense and environmental disturbance of sampling for fresh material.

Stage 1. Identify target taxa from existing biological collections

Candidate taxa need to have;

- Appropriate spatial coverage: samples span the extent of disturbance and/or the regional extent of the species

- Appropriate temporal coverage: samples span biologically meaningful timescales to investigate changes in connectivity over time

- Sufficient individuals at each sample location

Stage 2. Check suitability of selected archived material Selected material needs to be;

- Preserved appropriately: usually ethanolor frozen; DNA from dry or formalin-preserved samples may be damaged

- Suitable for tissue sub-sampling: type material may be unavailable for dissection, smaller individuals may not have sufficient tissue for successful DNA extraction

Stage 3. Test subset of selected material using genetic markers

- Subsets of approx. $n=6$ from each sample are screened using the chosen markers

- Selected genetic markers are checked for suitability (sufficient intraspecific variation, neutrality)

- Samples and/or markers that fail to provide sequences of sufficient quality are discarded

Stage 4. Batch process successful archived material

- All suitable archived material is processed using the selected genetic markers

- Spatial/temporaldistribution of sequences assessed against the original objectives Insufficient sequences

Stage 5 . Identify priorities for new sampling

- Spatial gaps in sequence distribution identified and prioritised for future samplecollection

- Additional samples are collected and processed

Stage 7. Results are interpreted to generate environmental management recommendations

Figure 6. Suggested stepwise plan for using archived biological material in population genetic connectivity assessments with the aim to inform environmental management decisions. 


\section{Acknowledgements}

We thank the NIWA Invertebrate Collection staff (Kareen Schnabel, Sadie Mills and Dean Stotter) for their assistance in locating G. gladius material. We also thank the scientists and crew aboard the research voyages used to collect this material and acknowledge the support of the institutions involved with these voyages. The NIWA Invertebrate Collection provided specimens collected under the following projects: 'Seamounts: their importance to fisheries and marine ecosystems', funded by the former New Zealand Foundation for Research, Science and Technology; 'Impact of resource use on vulnerable deep-sea communities' project (DSC) (CO1X0906), funded by the Ministry of Business, Innovation \& Employment (MBIE); 'Nascent Inter-Ridge Volcanic And Neotectonic Activity', funded by the Ministry for Primary Industries (MPI), in collaboration with Auckland University, GNS Science (NZ) and the University of New Hampshire (USA) and with funding from the DSC program; the joint New Zealand-USA 2005 NOAA 'Ring of Fire Expedition'; 'Marine Geoscientific Research on Input and Output in the Tonga-Kermadec Subduction Zone', a joint German-Canadian-New Zealand expedition led by the University of Kiel and the Federal Institute for Geosciences and Natural Resources; 'Scientific Observer Program' funded by MPI. RB would like to thank Catarina Silva for assistance in the laboratory work involved in this study. RB is supported by PhD scholarship funding from NIWA and Victoria University of Wellington. The research reported here is part of the NIWA project 'Deep-sea mining of the Kermadec Arc - Geophysical prospectivity and environmental impacts' funded by the New Zealand Ministry of Business, Innovation and Employment (formally the Foundation for Research Science and Technology) (contract CO1X0702). We would also like to thank two anonymous reviewers for their constructive comments on the manuscript.

\section{References}

Arellano SM, Young CM (2009) Spawning, development, and the duration of larval life in a deep-sea cold-seep mussel. Biological Bulletin 216, 149-162.

Arevalo E, Davis SK, Sites W Jr. (1994). Mitochondrial DNA sequnce divergence and phylogenetic relationships among eight chromosome races of the Scleroporus grammicus complex (Phrynosomatidae) in Central Mexico. Systematic Biology 43, 387418.

Baker E, Beaudoin Y (eds.) (2013) Deep sea minerals: sea floor massive sulphides, a physical, biological, environmental, and technical review, Vol $1 \mathrm{~A}$. Secretariat of the Pacific Community, 52 pp. 
Bandelt H, Forster P, Röhl A (1999) Median-joining networks for inferring intraspecific phylogenies. Molecular Biology and Evolution 16, 37-48.

Bielawski JP, Gold JR (1996) Unequal synonymous substitution rates within and between two protein-coding mitochondrial genes. Molecular Biology and Evolution 13, 889-892.

Bors EK, Rowden AA, Maas EW, Clark MR, Shank TM (2012) Patterns of deep-sea genetic connectivity in the New Zealand region: implications for management of benthic ecosystems. Plos One 7, e49474.

Boschen RE, Rowden AA, Clark MR, Barton SJ, Pallentin A, Gardner JPA (2015) Megabenthic assemblage structure on three New Zealand seamounts: implications for seafloor massive sulfide mining. Marine Ecology Progress Series 523, 1-14.

Boschen RE, Rowden AA, Clark MR, Gardner JPA (2013) Mining of deep-sea seafloor massive sulfides: a review of the deposits, their benthic communities, impacts from mining, regulatory frameworks and management strategies. Ocean and Coastal Management 84, 54-67.

Bouchet P, Warén A (1991) Ifremeria nautilei, a new gastropod from hydrothermal vents, probably associated with symbiotic bacteria. Comptes Rendus de l'Académie des Sciences Paris Series III 312, 495-501.

Carney SL, Formica MI, Divatia H, Nelson K, Fisher CR, Schaeffer SW (2006) Population structure of the mussel "Bathymodiolus" childressi from Gulf of Mexico hydrocarbon seeps. Deep-Sea Research Part I-Oceanographic Research Papers 53, 1061-1072.

Chiswell SM, Bostock HC, Sutton PJH, Williams MJM (2015) Physical oceanography of the deep seas around New Zealand: a review. New Zealand Journal of Marine and Freshwater Research 49, 286-317.

Chiswell SM, Sutton PJH (2015) Drifter- and float-derived mean circulation at the surface and $1000 \mathrm{~m}$ in the New Zealand region. New Zealand Journal of Marine and Freshwater Research 49, 259-277.

Clark MR, O'Shea S (2001) Hydrothermal vent and seamount fauna from the southern Kermadec Ridge, New Zealand. InterRidge News 10, 14-17.

Coffey Natural Systems (2008) Environmental Impact Statement, Solwara 1 project, Nautilus Minerals Niugini limited, Main Report, Vol A. Coffey Natural Systems, Brisbane, Australia, 222 pp.

Collins PC, Croot P, Carlsson C, Colaço A, Grehan A, Hyeong K, Kennedy R, Mohn C, Smith S, Yamamoto H, Rowden A (2013a) A primer for the Environmental Impact Assessment of mining at seafloor massive sulfide deposits. Marine Policy 42, 198-209. 
Collins PC, Kennedy R, Copley JT, Boschen R, Forde J, Se-Jong J, Lindsay D, Marsh L, Nye V, Patterson A, Watanabe H, Yamamoto H, Carlsson J, Thaler AD (2013b) VentBase: developing a consensus among stakeholders in the deep-sea regarding Environmental Impact Assessment for deep-sea mining - a workshop report. Marine Policy 42, 334-336.

Craddock C, Hoeh WR, Lutz RA, Vrijenhoek RC (1995) Extensive gene flow among mytilid (Bathymodiolus thermophilus) populations from hydrothermal vents of the eastern Pacific. Marine Biology 124, 137-146.

de Ronde CEJ, Massoth GJ, Butterfield DA, Christenson BW, Ishibashi J, Ditchburn RG, Hannington MD, Brathwaite RL, Lupton JE, Kamenetsky VS, Graham IJ, Zellmer GF, Dziak RP, Embley RW, Dekov VM, Munnik F, Lahr J, Evans LJ, Takai K (2011) Submarine hydrothermal activity and gold-rich mineralization at Brothers Volcano, Kermadec Arc, New Zealand. Mineralium Deposita 46, 541-584.

Devey CW, Fisher CR, Scott S (2007) Responsible science at hydrothermal vents. Oceanography 20, 162-171.

Dixon DR, Sole-Cava AM, Pascoe PL, Holland PWH (1995). Periostracal adventitious hairs on spat of the mussel Mytilus edulis. Journal of the Marine Biological Association of the United Kingdom 75, 363-372.

Excoffier L, Laval G, Schneider S (2005) Arlequin ver. 3.0: An integrated software package for population genetics data analysis. Evolutionary Bioinformatics Online 1, 47-50.

Excoffier L, Smouse P, Quattro J (1992) Analysis of molecular variance inferred from metric distances among DNA haplotypes: application to human mitochondrial DNA restriction data. Genetics 131, 479-491.

Fisher C, Skibinski D (1990) Sex-biased mitochondrial DNA heteroplasmy in the marine mussel Mytilus. Proceedings of the Royal Society B: Biological Sciences 242, 149-156.

Folmer O, Black MB, Hoeh WR, Lutz RA, Vrijenhoek R (1994) DNA primers for amplification of mitochondrial cytochrome $\mathrm{c}$ oxidase subunit I from diverse metazoan invertebrates. Molecular Marine Biology and and Biotechnology 3, 294-299.

Fontanez KM, Cavanaugh CM (2013) Phylogenetic relationships of hydrothermal vent mussels (Bathymodiolinae) and their symbionts. Marine Ecology Progress Series 474, 147-154.

Freeland J (2005) Molecular markers in ecology. In: Kirk H (ed.) Molecular Ecology. John Wiley and Sons, Chichester, UK, pp 1-62.

Hannington M, Jamieson J, Monecke T, Petersen S, Beaulieu S (2011) The abundance of seafloor massive sulfide deposits. Geology 39, 1155-1158. 
Hellberg ME, Burton RS, Neigel JE, Palumbi SR (2002) Genetic assessment of connectivity among marine populations. Bulletin of Marine Science 70, 273-290.

International Seabed Authority (2010) Regulations on prospecting and exploration for polymetallic sulphides in the Area. ISBA/16/A/12/Rev.1. International Seabed Authority, Kingston, Jamaica, 49 pp.

InterRidge (2009) InterRidge statement of commitment to responsible research practices at deep-sea hydrothermal vents [Online]. Available: http://www.interridge.org//RStatement (accessed March 27th 2015).

Jollivet D, Comtet T, Chevaldonné P, Hourdez S, Desbruyères D, Dixon DR (1998) Unexpected relationship between dispersal strategies and speciation within the association Bathymodiolus (Bivalvia)-Branchipolynoe (Polychaeta) inferred from the rDNA neutral ITS2 marker. Cahiers de Biologie Marine 39, 359-362.

Jones WJ, Won YJ, Maas PAY, Smith PJ, Lutz RA, Vrijenhoek RC (2006) Evolution of habitat use by deep-sea mussels. Marine Biology 148, 841-851.

Kyuno A, Shintaku M, Fujita $Y$, Matsumoto $H$, Utsumi $M$, Watanabe $H$, Fujiwara $Y$, Miyazaki J-I (2009) Dispersal and differentiation of deep-sea mussels of the genus Bathymodiolus (Mytilidae, Bathymodiolinae). Journal of Marine Biology 2009, 1-15.

Librado P, Rozas J (2009) DnaSP v5: a software for comprehensive analysis of DNA polymorphism data. Bioinformatics 25, 11, 1451-1452.

Liu ZJ, Cordes JF (2004) DNA marker technologies and their applications in aquaculture genetics. Aquaculture 238, 1-37.

Lutz RA, Shank TM, Fornari DJ, Haymon RM, Lilley MD, Vondamm KL, Desbruyères $D$ (1994) Rapid growth at deep-sea vents. Nature 371, 663-664.

Mantel N (1967). The detection of disease clustering and a generalized regression approach. Cancer Research 27, 209-220.

Marsh L, Copley JT, Huvenne VAI, Linse K, Reid WDK, Rogers AD, Sweeting CJ, Tyler PA (2012) Microdistribution of faunal assemblages at deep-sea hydrothermal vents in the Southern Ocean. Plos One 7, e48348.

Marsh L, Copley JT, Tyler PA, Thatje S (2015) In hot and cold water: differential life-history traits are key to success in contrasting thermal deep-sea environments. Journal of Animal Ecology 2015, 1-15.

Miller K, Williams A, Rowden AA, Knowles C, Dunshea G (2010) Conflicting estimates of connectivity among deep-sea coral populations. Marine Ecology an Evolutionary Perspective 31, 144-157. 
Miyazaki Jl, Beppu S, Kajio S, Dobashi A, Kawato M, Fujiwara Y, Hirayama H (2013) Dispersal ability and environmental adaptability of deep-sea mussels Bathymodiolus (Mytilidae: Bathymodiolinae). Open Journal of Marine Science 3, 31-39.

Olu-Le Roy K, Von Cosel R, Hourdez S, Carney SL, Jollivet D (2007) Amphi-Atlantic coldseep Bathymodiolus species complexes across the equatorial belt. Deep-Sea Research 54, 1890-1911.

Page HM, Faila-Médioni A, Fisher CR, Childress JJ (1991) Experimental evidence for filter-feeding by the hydrothermal vent mussel, Bathymodiolus thermophilus. Deep-Sea Research 38, 1455-1461.

Ramirez-Llodra E, Tyler PA, Baker MC, Bergstad OA, Clark MR, Escobar E, Levin LA, Menot L, Rowden AA, Smith CR, Van Dover CL (2011) Man and the last great wilderness: human impact on the deep sea. Plos One 6, 8, e22588.

Rowden AA, Clark MR, O'Shea S, Mcknight DG (2003) Benthic biodiversity of seamounts on the southern Kermadec Volcanic Arc. Marine Biodiversity Biosecurity Report 3, National Institute of Water and Atmospheric Research, Wellington, New Zealand, 23 pp.

Scholin CA, Anderson DM (1994) Identification of group-and strain-specific generic markers for globally distributed Alexandrium (Dinophyceae). I. RFLP analysis of SSU rRNA genes. Journal of Phycology 30, 44-54.

Sefc K, Payne R, Sorenson M (2007) Single base errors in PCR products from avian museum specimens and their effect on estimates of historical genetic diversity. Conservation Genetics 8, 879-884.

Shank TM, Halanych KM (2007) Toward a mechanistic understanding of larval dispersal: insights from genomic fingerprinting of the deep-sea hydrothermal vent tubeworm Riftia pachyptila. Marine Ecology an Evolutionary Perspective 28, 25-35.

Slatkin M (1995) A measure of population subdivision based on microsatellite allele frequencies. Genetics 139, 457-462.

Smith CR (1989) Vent fauna on whale remains. Nature 341, 27-28.

Smith PJ, Mcveagh SM, Won Y, Vrijenhoek RC (2004) Genetic heterogeneity among New Zealand species of hydrothermal vent mussels (Mytilidae: Bathymodiolus). Marine Biology 144, 537-545.

Smouse PE, Long, JC, Sokal RR (1986). Multiple regression and correlation extensions of the Mantel Test of matrix correspondence. Systematic Zoology 35, 627-632.

Thaler AD, Zelnio K, Saleu W, Schutttz TF, Carlsson J, Cunningham C, Vrijenhoek RC, Van Dover CL (2011) The spatial scale of genetic subdivision in populations of 
Ifremeria nautilei, a hydrothermalvent gastropod from the Southwest Pacific. BMC Evolutionary Biology 11, 372.

Tunnicliffe V, Embley RW, Holden JF, Butterfield DA, Massoth GJ, Juniper SK (1997) Biological colonization of new hydrothermal vents following an eruption on Juan de Fuca Ridge. Deep-Sea Research Pt I-Oceanographic Research Papers 44, 1627-1644. Van Dover CL (2011) Mining seafloor massive sulphides and biodiversity: what is at risk? ICES Journal of Marine Science 68, 341-348.

Van Dover CL (2014) Impacts of anthropogenic disturbances at deep-sea hydrothermal vent ecosystems: a review. Marine Environmental Reserch 102, 59-72.

Villesen P (2007) FaBox: an online toolbox for fasta sequences. Molecular Ecology Notes 7, 965-968.

Von Cosel RM, Marshall BA (2003) Two new species of large mussels (Bivalvia: Mytilidae) from active submarine volcanoes and a cold seep off the eastern North Island of New Zealand, with description of a new genus. Nautilus 117, 2, 31-46.

Vrijenhoek RC (2010) Genetic diversity and connectivity of deep-sea hydrothermal vent metapopulations. Molecular Ecology 19, 4391-4411.

Wagstaff SJ, Garnock-Jones PJ (1998) Evolution and bigeography of the Hebe compex (Scrophulariaceae) inferred from ITS sequences. New Zealand Journal of Botany 36, 425-437.

Wandeler P, Hoeck PEA, Keller LF (2007) Back to the future: museum specimens in population genetics. Trends in Ecology and Evolution 22, 634-642.

White TJ, Bruns T, Lee S, Taylor J (1990) Amplification and direct sequencing of fungal ribosomal RNA genes for phylogenetics. In: Innis MA, Gelfand, DH, Sninsky JJ, White TJ (eds.) PCR Protocols: A Guide to Methods and Applications. Academic Press, San Diego, CA, pp 315-322.

Won Y, Young CR, Lutz RA, Vrijenhoek RC (2003) Dispersal barriers and isolation among deep-sea mussel populations (Mytilidae: Bathymodiolus) from eastern Pacific hydrothermal vents. Molecular Ecology 12, 169-184.

Wood AR, Apte S, Macavoy ES, Gardner JPA (2007) A molecular phylogeny of the marine mussel genus Perna (Bivalvia: Mytilidae) based on nuclear (ITS1\&2) and mitochondrial (COI) DNA sequences. Molecular Phylogenetics and Evolution 44, 685-698. 


\section{Supplementary Information}

\section{Gigantidas gladius samples excluded from analysis}

Table S1. Gigantidas gladius specimens catalogued in the NIWA Invertebrate Collection but excluded from the analysis. *Fisheries trip locations reported to one decimal place. For latitude and longitude, '-' refers to decimal degrees South and West respectively.

\begin{tabular}{|c|c|c|c|c|c|c|c|c|c|c|}
\hline $\begin{array}{l}\text { Reason } \\
\text { excluded }\end{array}$ & $\begin{array}{c}\text { Catalogue } \\
\text { Number }\end{array}$ & Voyage & Station ID\# & Date & $\begin{array}{l}\text { Place } \\
\text { name }\end{array}$ & Latitude & Longitude & $\begin{array}{c}\text { Depth } \\
\text { range }(m)\end{array}$ & Gear & $\begin{array}{l}\text { Number of } \\
\text { individuals }\end{array}$ \\
\hline \multirow{4}{*}{ Paratype } & 5063 & TAN0107 & TAN0107/230 & $24 / 05 / 2001$ & $\begin{array}{l}\text { Rumble V } \\
\text { Seamount }\end{array}$ & -36.1413 & 178.1950 & $360-755$ & Epibenthic sled & 15 \\
\hline & 5073 & KAH0011 & KAH0011/12 & 02/11/2000 & $\begin{array}{l}\text { Rumble III } \\
\text { Seamount }\end{array}$ & -35.7341 & 178.4849 & 216 & Epibenthic sled & 30 \\
\hline & 18029 & TAN0107 & TAN0107/230 & $24 / 05 / 2001$ & $\begin{array}{l}\text { Rumble V } \\
\text { Seamount }\end{array}$ & -36.1413 & 178.1950 & $360-755$ & Epibenthic sled & 7 \\
\hline & 18029 & TAN0107 & TAN0107/230 & 24/05/2001 & $\begin{array}{l}\text { Rumble V } \\
\text { Seamount }\end{array}$ & -36.1413 & 178.1950 & $360-755$ & Epibenthic sled & 1 \\
\hline \multirow{5}{*}{$\begin{array}{l}\text { Formalin- } \\
\text { preserved }\end{array}$} & 15268 & KOK0505 & KOK0505/56 & 21/04/2005 & $\begin{array}{l}\text { Rumble V } \\
\text { Seamount }\end{array}$ & -36.1407 & 178.1982 & 486 & Submersible & 30 \\
\hline & 82110 & TAN1206 & TAN1206/17 & $16 / 04 / 2012$ & $\begin{array}{l}\text { Tangaroa } \\
\text { Seamount }\end{array}$ & -36.3247 & 178.0308 & $667-695$ & Epibenthic sled & 10 \\
\hline & 86967 & TAN0107 & TAN0107/5 & $19 / 05 / 2001$ & $\begin{array}{l}\text { Rumble III } \\
\text { Seamount }\end{array}$ & -35.7397 & 178.4975 & $220-420$ & Epibenthic sled & 30 \\
\hline & 87205 & TAN0107 & TAN0107/235 & $24 / 05 / 2001$ & $\begin{array}{l}\text { Rumble V } \\
\text { Seamount }\end{array}$ & -36.1393 & 178.1960 & $367-672$ & Epibenthic sled & 2 \\
\hline & 87307 & KAH0011 & KAH0011/11 & 01/11/2000 & $\begin{array}{l}\text { Rumble III } \\
\text { Seamount }\end{array}$ & -35.7410 & 178.4882 & $660-853$ & Epibenthic sled & 3 \\
\hline \multirow{2}{*}{ Smashed } & 5075 & KAH0011 & КАН0011/12 & 01/11/2000 & $\begin{array}{l}\text { Rumble III } \\
\text { Seamount }\end{array}$ & -35.7415 & 178.4983 & $312-437$ & Epibenthic sled & 10 \\
\hline & 87306 & KAH0011 & KAH0011/12 & 02/11/2000 & $\begin{array}{l}\text { Rumble III } \\
\text { Seamount }\end{array}$ & -35.7341 & 178.4849 & 216 & Epibenthic sled & 10 \\
\hline \multirow{3}{*}{ Too small } & 5075 & KAH0011 & KAH0011/12 & 01/11/2000 & $\begin{array}{l}\text { Rumble III } \\
\text { Seamount }\end{array}$ & -35.7415 & 178.4983 & $312-437$ & Epibenthic sled & 15 \\
\hline & 19349 & KOK0505 & KOK0505/56 & $21 / 04 / 2005$ & $\begin{array}{l}\text { Rumble V } \\
\text { Seamount }\end{array}$ & -36.1407 & 178.1982 & 486 & Submersible & 19 \\
\hline & 86447 & TAN1213 & TAN1213/59 & 26/10/2012 & $\begin{array}{l}\text { Rumble V } \\
\text { Seamount }\end{array}$ & -36.1415 & 178.1997 & $405-408$ & Epibenthic sled & 2 \\
\hline
\end{tabular}




\begin{tabular}{|c|c|c|c|c|c|c|c|c|c|c|}
\hline \multirow{13}{*}{$\begin{array}{l}\text { Poor } \\
\text { DNA }\end{array}$} & 5072 & TAN0107 & TAN0107/325 & $24 / 05 / 2001$ & $\begin{array}{l}\text { Rumble V } \\
\text { Seamount }\end{array}$ & -36.1377 & 178.1957 & $415-485$ & Epibenthic sled & 50 \\
\hline & 5075 & $\mathrm{KAH} 0011$ & KAH0011/12 & $01 / 11 / 2000$ & $\begin{array}{l}\text { Rumble III } \\
\text { Seamount }\end{array}$ & -35.7415 & 178.4983 & $312-437$ & Epibenthic sled & 37 \\
\hline & 18029 & TAN0107 & TAN0107/230 & $24 / 05 / 2001$ & $\begin{array}{l}\text { Rumble V } \\
\text { seamount }\end{array}$ & -36.1413 & 178.1950 & $360-755$ & Epibenthic sled & 7 \\
\hline & 24594 & 9912 & TRIP1597/79 & 10/02/2002 & $\begin{array}{l}\text { Giljanes } \\
\text { Seamount }\end{array}$ & $-34.8^{*}$ & $178.6^{*}$ & 680 & Bottom Trawl & 3 \\
\hline & 86967 & TAN0107 & TAN0107/5 & $19 / 05 / 2001$ & $\begin{array}{l}\text { Rumble III } \\
\text { Seamount }\end{array}$ & -35.7397 & 178.4975 & $220-420$ & Epibenthic sled & 77 \\
\hline & 87106 & TAN0107 & TAN0107/216 & $23 / 05 / 2001$ & $\begin{array}{l}\text { Rumble III } \\
\text { Seamount }\end{array}$ & -35.7397 & 178.4960 & $230-420$ & Epibenthic sled & 100 \\
\hline & 87205 & TAN0107 & TAN0107/235 & $24 / 05 / 2001$ & $\begin{array}{l}\text { Rumble V } \\
\text { Seamount }\end{array}$ & -36.1393 & 178.1960 & $367-672$ & Epibenthic sled & 2 \\
\hline & 87206 & TAN0107 & TAN0107/230 & $24 / 05 / 2001$ & $\begin{array}{l}\text { Rumble V } \\
\text { seamount }\end{array}$ & -36.1413 & 178.1950 & $360-755$ & Epibenthic sled & 7 \\
\hline & 87309 & TAN0107 & TAN0107/324 & $24 / 05 / 2001$ & $\begin{array}{l}\text { Rumble V } \\
\text { Seamount }\end{array}$ & -36.1382 & 178.1957 & $470-730$ & Epibenthic sled & 27 \\
\hline & 87474 & TAN0107 & TAN0107/2 & $19 / 05 / 2001$ & $\begin{array}{l}\text { Rumble III } \\
\text { Seamount }\end{array}$ & -35.7397 & 178.4973 & $207-382$ & Epibenthic sled & 49 \\
\hline & 91949 & TAN0205 & TAN0205/55 & $21 / 04 / 2002$ & $\begin{array}{l}\text { Macauley } \\
\text { Cone }\end{array}$ & -30.2173 & -178.4518 & $480-504$ & Rock dredge & 30 \\
\hline & 5072 & TAN0107 & TAN0107/325 & $24 / 05 / 2001$ & $\begin{array}{l}\text { Rumble V } \\
\text { Seamount }\end{array}$ & -36.1377 & 178.1957 & $415-485$ & Epibenthic sled & 37 \\
\hline & 87106 & TAN0107 & TAN0107/216 & $23 / 05 / 2001$ & $\begin{array}{l}\text { Rumble III } \\
\text { Seamount }\end{array}$ & -35.7397 & 178.4960 & $230-420$ & Epibenthic sled & 153 \\
\hline \multirow{5}{*}{$\begin{array}{c}\text { Poor } \\
\text { sequence }\end{array}$} & 19349 & KOK0505 & KOK0505/56 & $21 / 04 / 2005$ & $\begin{array}{l}\text { Rumble V } \\
\text { Seamount }\end{array}$ & -36.1407 & 178.1982 & 486 & Submersible & 10 \\
\hline & 32805 & KOK0505 & KOK0505/56 & $21 / 04 / 2005$ & $\begin{array}{l}\text { Rumble V } \\
\text { Seamount }\end{array}$ & -36.1407 & 178.1982 & 486 & Submersible & 1 \\
\hline & 82111 & TAN1206 & TAN1206/17 & $16 / 04 / 2012$ & $\begin{array}{l}\text { Tangaroa } \\
\text { Seamount }\end{array}$ & -36.3247 & 178.0308 & 667-695 & Epibenthic sled & 1 \\
\hline & 82124 & TAN1206 & TAN1206/17 & $16 / 04 / 2012$ & $\begin{array}{l}\text { Tangaroa } \\
\text { Seamount }\end{array}$ & -36.3247 & 178.0308 & 667-695 & Epibenthic sled & 1 \\
\hline & 84453 & KOK0505 & KOK0505/56 & $21 / 04 / 2005$ & $\begin{array}{l}\text { Rumble V } \\
\text { Seamount }\end{array}$ & -36.1407 & 178.1982 & 486 & Submersible & 3 \\
\hline
\end{tabular}




\section{CHAPTER 6: Synopsis}

Determining suitable environmental management strategies for SMS mining needs to utilise all of the available information, including that provided by the preceding chapters. The integrated findings of this thesis highlight the need for a network of protected seabed areas along the Kermadec Volcanic Arc to help mitigate the impacts of any future SMS mining activities. This network should be highly connected (as determined by genetic connectivity) and include both hydrothermally active and inactive SMS areas to conserve 1) the endemic vent fauna in active areas and 2) the unique assemblages found in both environments.

Concepts from broader ecological and conservation theory could aid the establishment of a protected area network along the Arc (detailed in Chapter 1) but it remains a daunting prospect. To provide some of the background necessary for environmental managers, this thesis offers a condensed review of the current knowledge pertinent to the environmental management of SMS deposits (Chapter 2: Boschen et al. 2013). One of the biggest issues for management of Kermadec Volcanic Arc SMS deposits is the lack of information regarding benthic assemblages colonising deposits and the degree of connectivity amongst assemblages at different locations. To help address this knowledge gap, this thesis adopted a multidisciplinary approach. First, video surveys provided detailed information on SMS deposit and wider seamount assemblages at two spatial scales (Chapters 3 and 4: Boschen et al. 2015b, Boschen et al. 2016b). Second, molecular techniques were used to assess the genetic connectivity of populations of an endemic hydrothermal vent mussel colonising areas previously licenced for the prospecting phase of SMS mining (Chapter 5: Boschen et al. 2015a). A critical overview of these studies, including how their key findings can contribute to protected area network design, forms the basis of this Synopsis (Chapter 6).

The research presented here includes an account of assemblage structure at a licenced SMS deposit, with only one previous account published globally to date (Collins et al. 2012). The studies in this thesis also provide the first description of assemblages unique to inactive sulfide areas, lending a degree of support to the existence of fauna endemic to the weathered sulfide environment (Van Dover 2011). The assemblage structure surveys at both spatial scales are statistically robust with considerable spatial coverage; the three-seamount survey analysed a total of $49.8 \mathrm{~km}$ of seabed transects, whilst the mine and Reference site comparison analysed $2.3 \mathrm{~km}$ of transect across the two 
sites. The population connectivity study on Gigantidas gladius was the first to investigate patterns of genetic connectivity of a hydrothermal vent species endemic to New Zealand and provided insights into the suitability of archived material for connectivity assessments. Overall the studies reported in this thesis contribute significantly to the field of SMS deposit ecology, as detailed above. However, due to a number of obstacles relating to data and sample availability, the conclusions that can be drawn from this research are subject to some constraints.

The genetic connectivity of G. gladius populations along the Arc had access to 942 individuals accessioned within the NIWA Invertebrate Collection (NIC). However, only 150 individuals were able to provide usable sequences for genetic analysis, largely due to poor tissue quality of archived samples. Small sample sizes limited the ability to detect genetic structure amongst populations, meaning caution must be taken when using these results to develop management recommendations. These specimens represent all of the available G. gladius samples archived globally; for population connectivity patterns to be further substantiated there would need to be extensive additional sampling of $G$. gladius. Different molecular markers can provide different views of connectivity, whilst different species at SMS deposits could also exhibit varying patterns of connectivity amongst populations (Boschen et al. 2016a). Recommendations for future SMS deposit connectivity studies would be to supplement archived material with fresh collections in order to provide sufficient individuals for robust statistical analysis; and to utilise multiple molecular markers across a range of species to provide a more holistic view of connectivity amongst SMS deposits.

Although the spatial coverage of the seamount survey was considerable, Rumble II East, Brothers and Rumble II West are just three of the 78 seamounts that occur along the Kermadec Volcanic Arc, many of which fall within areas previously licenced for the prospecting phase of SMS mining (Fig. 1). Little is published on the benthic assemblages at the majority of these seamounts; for a protected area network to be established, the survey techniques employed in this study would need to be extended across a greater array of seamounts along the Kermadec Volcanic Arc.

Both the seamount and site-comparison studies used contiguous video transect data that was subsequently divided into smaller segments for analysis. This introduces the issue of spatial auto-correlation; adjacent samples are more likely to be similar than those further away. Although spatial auto-correlation does not bias towards finding a certain result, it can influence significance testing, as the samples are not independent (Wilson 1999). The issue occurs at all scales; samples a few cm's apart can be similar within a $1 \mathrm{~m}$ 
sample, but so can samples a few km's apart when the sampled area is $100 \mathrm{~km}$ (Wilson 1999). Future studies using video transect data should investigate options that can address the issue of spatial auto-correlation, such as patch models (Watkins and Wilson 1992), accumulation of variation within areas (Wilson and Roxburgh 1994), rotation and random shifts methods (Palmer and van der Maarel 1995) and the random patterns test (Roxburg and Chesson 1998).

For the two-site survey, although spatial coverage within the proposed mine site and proposed reference site was extensive, the study was limited, in that it only compared one potential mine site, Proteus 1, with one potential reference site. Whilst the number of sites is often constrained for deep sea studies as a result of survey logistics and cost, this restricts the conclusions that can be drawn. Without replication, it is difficult to know if survey results are 'normal' or the result of a rare event that depends on space and time; the only way to increase reliability is repetition (Schmitz 2007). Replication, in terms of multiple survey sites and re-visiting the same sites on multiple occasions, is essential to address the natural spatial and temporal environmental variability at SMS sites. To investigate the effect of SMS mining on benthic assemblages and to determine the suitability of protected areas, survey design should incorporate multiple un-impacted (control or set aside) and impacted (mined) sites (Collins et al. 2013a), sensu Beyond Before-After-Control-Impact (BACl: Green 1979, Underwood 1991, 1992). Although the expense of surveying multiple sites in the deep sea is often prohibitive, replication is as important in forming robust scientific conclusions within the deep sea as it is in other environments; only by using methodologies as rigorous as those in the terrestrial, freshwater and shallow marine environments can SMS ecosystems be effectively managed under the precautionary principle (Collins et al. 2013b).

It should also be noted that one reference site does not equal a network of protected areas. The only other study to compare a mine and reference site (Solwara 1 and South Su respectively, off Papua New Guinea; Collins et al. 2012) identifies a single site for protection in the case of mining at Solwara 1. The regulations issued by the International Seabed Authority for the prospecting and exploration phases of SMS mining do not stipulate the number of protected areas required or make any recommendations for these areas to form a network (International Seabed Authority 2010). As such, the 'one mine site, one reference site' model currently implemented by Nautilus is technically in line with current international environmental regulations for SMS mining. However, the use of a single protected area to mitigate the impact of anthropogenic disturbance is at variance with international conservation measures for shallow marine environments, where there is 
a move towards coherent networks of protected areas (IUCN 2008). Regulations for the commercial exploitation phase of SMS mining have yet to be released by the International Seabed Authority, so it remains to be seen whether these guidelines reflect the widelyaccepted need for networks of protected areas in the deep sea, as opposed to single sites (Van Dover et al. 2012, International Seabed Authority 2011).

Whilst the survey tracks in the three-seamount study were distributed in a similar manner across the three seamounts, the pattern of survey was different between Proteus 1 and the Reference Site. The survey tracks at the Reference Site were distributed as linear, equally spaced transects across the site; those at Proteus 1 were meandering and overlapping, concentrated around the areas of hydrothermal activity. Whilst it is well known that surveys comparing sites should use the same methods to avoid introducing sampling bias, this is not always possible. For the comparison of Proteus 1 and the Reference Site, the video data was provided by a previously undertaken industry survey, so it was not possible to design transects that sampled both sites in a similar fashion. The use of fortuitous industry data can enable studies that would not otherwise be possible, however for robust recommendations to be made on protected area suitability, there needs to be a dedicated survey of multiple mine and reference sites that uses the same methods across all sites.

It should also be considered that the three-seamount and site-comparison studies were only able to assess the structure of megabenthic assemblages and did not consider any of the other size fractions of benthic fauna at SMS deposits. 'Megabenthic' is often defined operationally; in these studies, the term refers to organisms visible from video survey, typically larger than $5 \mathrm{~cm}$ in size. As the term 'community' in an ecological sense refers to "the individuals of all species that potentially interact within a single patch or local area of a habitat" (Holyoak et al. 2005, p8); these studies were only able to characterise assemblage structure and not the community structure of SMS deposits as a whole. To achieve this, there would need to be additional surveys focussed on biological sampling (such as sleds, grabs, cores or suction) to collect and asses the macro-, micro- and meiofaunal assemblage structure. Combining information across the size fractions of the benthic fauna would enable a true community perspective on SMS deposit ecology to be established.

There are still large gaps in our appreciation of SMS ecology that will hinder the progress of designing suitable management strategies. The biggest of these is to what degree habitats subjected to SMS mining are able to recover, and how long recovery may take. This is a complex issue and was unfortunately beyond the scope of this thesis to 
address. Without a precedent for SMS mining, it is hard to predict the impact it could have on benthic assemblages and develop appropriate mitigation strategies. In the absence of controlled experiments to determine the effects of SMS mining, any predictions are based on the impact of and recovery from large scale natural disturbances, such as those resulting from volcanic and tectonic activity (Lutz et al. 1994, Shank et al. 1998, Tunnicliffe et al. 1997). However, as the mechanisms of these disturbances differ from those involved in SMS mining, the impacts they have on the benthic fauna could also be different.

Ultimately, until a mining operation proceeds to the commercial exploitation stage and its management strategy is implemented and evaluated, whether the proposed protection measures are adequate will remain unknown. Alternative mitigation methods, such as organism relocation and the provision of artificial substrata in an effort to restore mined areas also remain to be tested (Van Dover et al. 2014). Although restoration programmes are common in terrestrial and freshwater environments to facilitate recovery, preliminary studies have indicated the cost of restoring areas mined for SMS may be prohibitive (Van Dover et al. 2014). With the general uncertainty around the recovery and restoration of mined areas, designating a coherent network of protected areas appears to be the most pragmatic mitigation strategy currently available to environmental managers. Such a strategy would be in line with the Precautionary Approach, as defined in Principle 15 of the Rio Declaration (United Nations Environment Programme 1992).

Since the completion of these studies, the New Zealand government has announced the Kermadec Ocean Sanctuary (Ministry for the Environment 2015); a $620000 \mathrm{~km}^{2}$ area of seabed that will provide protection from mining for all of the assemblages at SMS deposits in the far north of the EEZ (Fig. 1). However, many of the benthic assemblages at seamounts south of the Sanctuary are not afforded the same protection, including those inhabiting the three seamounts studied in this thesis. Brothers, Rumble II East and Rumble II West are within the Tectonic Reach Benthic Protection Area (BPA), which protects them from bottom trawling, but does not provide any protection from mining. There are other seamounts south of Tectonic Reach that have been previously licenced for the prospecting phase of SMS mining and are not currently afforded any form of protection (Fig. 1). 


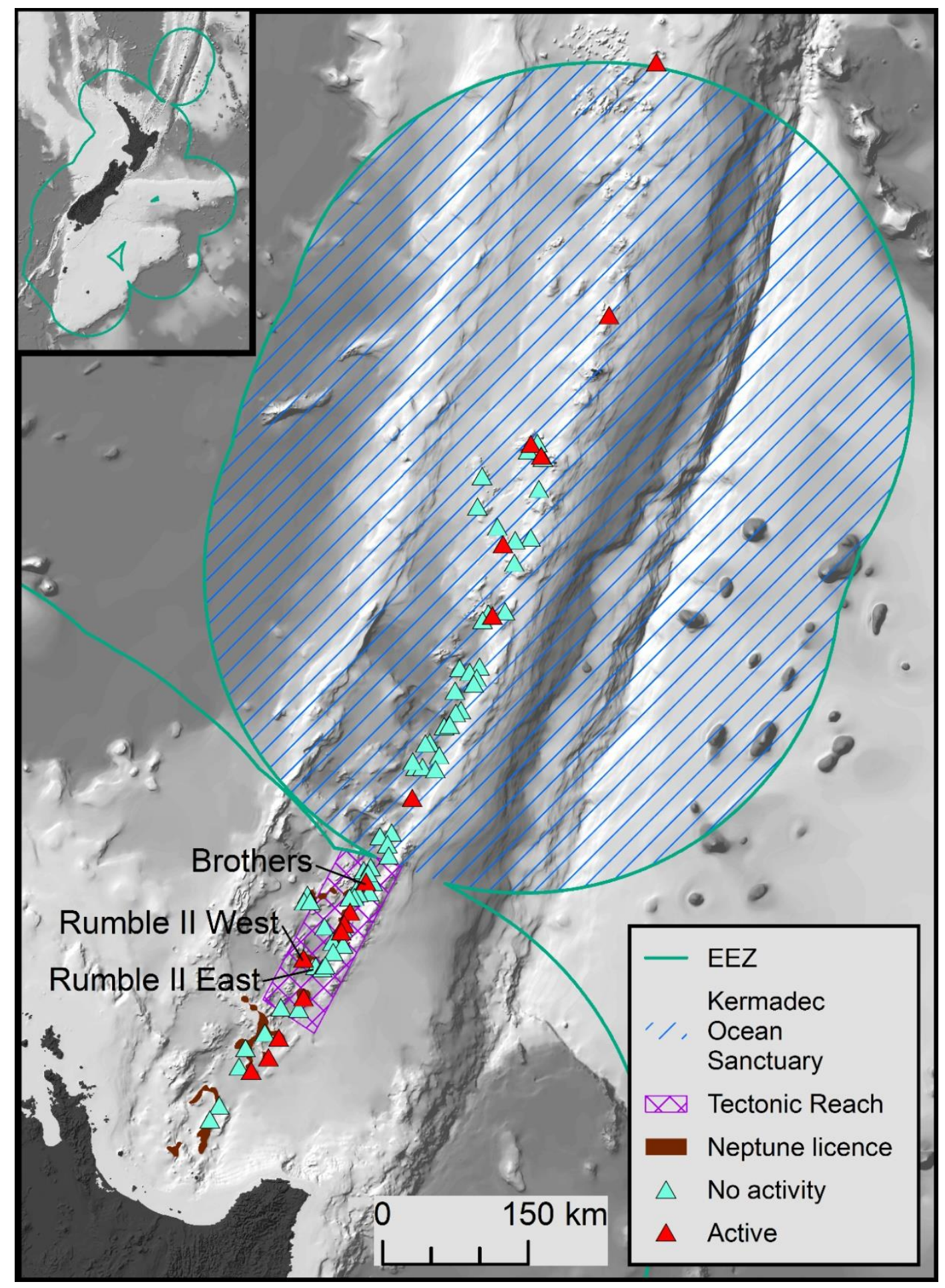

Figure 1. The location of marine boundaries, protected areas, SMS prospecting licenses and seamounts along the Kermadec Volcanic Arc, relative to New Zealand. Main figure: the New Zealand Exclusive Economic Zone (EEZ: green line), the Kermadec Benthic Protection Area (BPA) and the proposed Kermadec Ocean Sanctuary (blue diagonal lines), Tectonic Reach BPA (purple hash), Neptune Minerals Inc. prospecting licence areas (dark brown), and seamounts coded by hydrothermal activity; no hydrothermal activity detected (no activity: pale green triangles) and active (red triangles). The three labelled seamounts (Brothers, Rumble II West, Rumble II East) are the locations for the three studies. Inset: New Zealand mainland and EEZ. 
To ensure benthic assemblages at SMS deposit communities along the Kermadec Volcanic Arc are suitably protected, there needs to be a systematic approach to conservation planning, as more typically used in terrestrial, freshwater and shallow marine environments (Margules and Pressey 2000). Conservation planning is the process of deciding how best to utilize conservation resources to minimise the loss of biodiversity, amongst other valued natural elements (Pressey and Botrill 2009). Pressey and Logan (1997) outlined a basic six-step process that could be adapted for the Arc;

1) Compilation of biodiversity data along the Arc, to which this thesis contributes;

2) Identify conservation objectives, such as preserving biodiversity that could otherwise be lost through mining activities;

3) Review current achievement of conservation objectives, including existing preservation areas, such as BPAs and the Kermadec Ocean Sanctuary;

4) Select additional sites as necessary to create a coherent network, for example by including unprotected areas south of Tectonic Reach;

5) Apply conservation actions, including formal designation of new areas;

6) Manage selected areas to maintain their conservation value.

The basic six-step process of Pressey and Logan (1997) was later expanded to include five prior steps, acknowledging the placement of conservation planning within an often complex socio-economic and political environment (Pressey and Botrill 2009). These stages include 1) Costing the planning process; 2) Engaging with stakeholders; 3) Describing the regional context; 4) Identifying conservation goals; and 5) Collecting data on socio-economic considerations (Pressey and Botrill 2009). These additional aspects are important elements of conservation planning within the terrestrial environment, where there is often a need to consider multiple land-uses, acknowledging that sites with conservation value may also be of interest for economic development (Pressey and Botrill 2009).

An example of systematic conservation planning within the deep sea is the world's first Chemosynthetic Ecosystem Reserve, 'Endeavour Hydrothermal Vents Marine Protected Area' (EHV MPA). EHV MPA contains five vent fields split between four management areas catering for observational research, education and outreach and more intrusive research, demonstrating that it is possible to integrate multiple seabed uses and graded levels of protection into hydrothermal vent management (Fisheries and Oceans Canada 2009). Systematic conservation planning has also been used to design a network 
of protected areas ('Areas of Particular Environmental Interest' - APEIs) for polymetallic nodule mining at the Clarion-Clipperton Fracture Zone (CCZ) in the abyssal Pacific (Wedding et al. 2013, Wedding et al. 2015). A network of nine large APEls covering an area of $144000 \mathrm{~km}^{2}$ was established across the CCZ; although the network may not be placed in the most optimal arrangement, with the best network arrangement as determined by science compromised by existing licence claims (Wedding et al. 2013, Wedding et al. 2015).

If deep-sea mining continues to be of interest to the New Zealand government, it would be necessary to negotiate multiple seabed uses along the Arc, with some SMS deposits protected from mining and others ear-marked for exploitation. Undertaking these negotiations prior to additional licence areas being granted is essential, to ensure there is the opportunity to establish protected areas in ecologically optimal locations. Such decisions could be made more transparently and inclusively using a systematic conservation planning approach that actively engages with multiple stakeholders. In the case of determining a coherent network of protected areas along the Kermadec Volcanic Arc, systematic conservation has the added advantage that site connectivity can be integrated with the planning to determine protected area configurations that would best support persistence of populations amongst sites (Kininmonth et al. 2011).

In summary, this thesis offers an important contribution to the field of SMS deposit ecology. The research reported here provides information essential not only to the environmental management of SMS deposits within the New Zealand EEZ but also relevant to the management of benthic assemblages at deposits in other locations. Five contracts for SMS exploration have been issued in international waters (International Seabed Authority 2016), whilst the first SMS commercial exploitation licence has already been issued to Nautilus Minerals Inc. for seabed offshore of Papua New Guinea (Nautilus Minerals Inc. 2016). Elsewhere in the Western Pacific, Neptune Minerals Inc. holds tenements in the EEZs of Japan, Papua New Guinea, Solomon Islands, Vanuatu, Fiji,

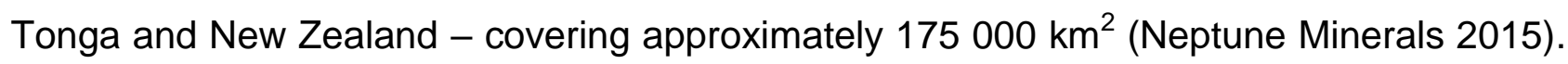
With the first SMS mining projects expected to undertake commercial mining before 2020 (Baker and Beaudoin 2013), there is an urgent need to characterise the ecology of SMS deposits in order to provide the information required to develop coherent networks of protected areas, ideally as part of a systematic conservation planning approach. 


\section{References}

Baker E, Beaudoin Y (eds.) (2013) Deep sea minerals: sea floor massive sulphides, a physical, biological, environmental, and technical review, Vol 1A. Secretariat of the Pacific Community, 52 pp.

Boschen RE, Collins PC, Tunnicliffe V, Carlsson J, Gardner JPA, Loew J, McCrone A, Metaxas A, Sinniger F, Swaddling A (2016a) A primer for use of genetic tools in selecting and testing the suitability of set-aside sites protected from deep-sea seafloor massive sulfide mining activities. Ocean \& Coastal Management 122, 37-48.

Boschen RE, Rowden AA, Clark MR, Gardner JPA (2015a) Limitations in the use of archived vent mussel samples to assess genetic connectivity among seafloor massive sulfide deposits: a case study with implications for environmental management. Frontiers in Marine Science 2, 1-14.

Boschen RE, Rowden AA, Clark MR, Barton SJ, Pallentin A, Gardner JPA (2015b) Megabenthic assemblage structure on three New Zealand seamounts: implications for seafloor massive sulfide mining. Marine Ecology Progress Series 523, 1-14.

Boschen RE, Rowden AA, Clark MR, Gardner JPA (2013) Mining of deep-sea seafloor massive sulfides: A review of the deposits, their benthic communities, impacts from mining, regulatory frameworks and management strategies. Ocean \& Coastal Management 84, 54-67.

Boschen RE, Rowden AA, Clark MR, Pallentin A, Gardner JPA (2016b) Seafloor massive sulfide deposits support unique megafaunal assemblages: implications for seabed mining and conservation. Marine Environmental Research 115, 78-88.

Collins PC, Croot P, Carlsson C, Colaço A, Grehan A, Hyeong K, Kennedy R, Mohn C, Smith S, Yamamoto H, Rowden A (2013a) A primer for the Environmental Impact Assessment of mining at seafloor massive sulfide deposits. Marine Policy 42, 198-209.

Collins PC, Kennedy R, Copley JT, Boschen RE, Forde J, Se-Jong J, Lindsay D, Marsh L, Nye V, Patterson A, Watanabe H, Yamamoto H, Carlsson J, Thaler AD (2013b) VentBase: Developing a consensus among stakeholders in the deep-sea regarding environmental impact assessment for deep-sea mining - a workshop report. Marine Policy 42, 334-336.

Collins PC, Kennedy R, Van Dover CL (2012) A biological survey method applied to seafloor massive sulphides (SMS) with contagiously distributed hydrothermal-vent fauna. Marine Ecology Progress Series 452, 89-107.

Fisheries and Oceans Canada (2009) Endeavour Hydrothermal Vents Marine Proteced Area management plan. Fisheries and Oceans Canada, Vancouver, Canada, 42 pp. 
Green RH (1979) Sampling design and statistical methods for environmental biologists. Wiley, New York, NY, 272 pp.

Holyoak M, Leibold MA, Mouquet NM, Holt RD, Hoopes MF (2005) Metacommunities: a framework for large-scale community ecology. In: Holyoak M, Leibld MA, Holt RD (eds.) Metacommunities: spatial dynamics and ecological communities. University of Chicago Press, Chicago, IL, pp 1-31.

International Seabed Authority (2010) Regulations on prospecting and exploration for polymetallic sulphides in the Area. ISBA/16/A/12/Rev.1. International Seabed Authority, Kingston, Jamaica, 49 pp.

International Seabed Authority (2011) Environmental management of deep-sea chemosynthetic ecosystems: justification of and considerations for a spatially-based approach. ISA Technical Study Series, 9. International Seabed Authority, Kingston, Jamaica, $79 \mathrm{pp}$.

International Seabed Authority (2016) Deep seabed minerals contractors - overview [Online]. Available: https://www.isa.org.jm/deep-seabed-minerals-contractors?qtcontractors tabs alt=1 (accessed May 20th 2016).

IUCN (2008) Establishing resilient marine protected area networks - making it happen. IUCN World Commission on Protected Areas (IUCN-WCPA), National Oceanic and Atmospheric Administration and The Nature Conservancy, Washington, DC, 118 pp.

Kininmonth S, Beger M, Bode M, Peterson E, Adams VM, Dorfman D, Brumbaugh DR, Possingham HP (2011) Dispersal connectivity and reserve selection for marine conservation. Ecological Modelling 222, 1272-1282.

Lutz RA, Shank TM, Fornari DJ, Haymon RM, Lilley MD, Vondamm KL, Desbruyères D (1994) Rapid growth at deep-sea vents. Nature 371, 663-664.

Margules CR, Pressey RL (2000) Systematic conservation planning. Nature 405, 243-253. Ministry for the Environment (2015) Kermadec Ocean Sanctuary [Online]. Available: www.mfe.govt.nz (accessed May 20 ${ }^{\text {th }}$ 2016).

Nautilus Minerals Inc. (2016) The pipeline: PNG [Online]. Available: http://www.nautilusminerals.com/irm/content/png.aspx?RID=258 (accessed May 16th 2016).

Neptune Minerals (2015) Our business: Tenements [Online]. Available: http://www.neptuneminerals.com/our-business/tenements/ (accessed May 20th 2016).

Palmer MW, van der Maarel E (1995) Variance in species richnes, species association, and niche limitation. Oikos 73, 203-213. 
Pressey RL, Botrill MC (2009) Approaches to landscape- and seascape-scale conservation planning: convergence, contrasts and challenges. Oryx 43, 464-475.

Pressey RL, Logan VS (1997) Inside looking out: findings of research on reserve selection relevant to 'off-reserve' nature conservation. In: Hale P, Lamb D (eds.) Conservation outside nature reserves, Centre for Conservation Biology, University of Queensland, Brisbane, Australia, pp 407-418.

Schmitz OJ (2007) Protecting biological diversity and ecosystem function. Ecology and ecosystem conservation. Island Press, Washington, DC, pp 115-125.

Shank TM, Fornari DJ, Von Damm KL, Lilley MD, Haymon RM, Lutz RA (1998) Temporal and spatial patterns of biological community development at nascent deep-sea hydrothermal vents (9 degrees 50 ' N, East Pacific Rise). Deep-Sea Research Part IITopical Studies in Oceanography 45, 465-515.

Tunnicliffe V, Embley RW, Holden JF, Butterfield DA, Massoth GJ, Juniper SK (1997) Biological colonization of new hydrothermal vents following an eruption on Juan de Fuca Ridge. Deep-Sea Research Part I-Oceanographic Research Papers 44, 16271644.

Underwood A (1991) Beyond BACl: Experimental designs for detecting human environmental impacts on temporal variations in natural populations. Marine and Freshwater Research 42, 569-587.

Underwood AJ (1992) Beyond BACl: the detection of environmental impacts on populations in the real, but variable, world. Journal of Experimental Marine Biology and Ecology 161, 145-178.

United Nations Environment Programme. Rio Declaration on Environment and Development [Online]. Available: http://www.unep.org/documents. multilingual/default.asp?documentid=78\&articleid=116 3 (accessed December 19th 2012).

Van Dover CL (2011) Mining seafloor massive sulphides and biodiversity: what is at risk? ICES Journal of Marine Science 68, 341-348.

Van Dover CL, Aronson J, Pendleton L, Smith S, Arnaud-Haond S, Moreno-Mateos D, Barbier E, Billett D, Bowers K, Danovaro R, Edwards A, Kellert S, Morato T, Pollard E, Rogers A, Warner R (2014) Ecological restoration in the deep sea: Desiderata. Marine Policy 44, 98-106.

Van Dover CL, Smith CR, Ardron J, Dunn D, Gjerde K, Levin L, Smith S (2012) Designating networks of chemosynthetic ecosystem reserves in the deep sea. Marine Policy 36, 378-381. 
Watkins AJ, Wilson JB (1992) Fine-scale community structure of lawns. Journal of Ecology 80, 15-24.

Wedding LM, Friedlander AM, Kittinger JN, Watling L, Gaines SD, Bennett M, Hardy SM, Smith CR (2013) From principles to practice: a spatial approach to systematic conservation planning in the deep sea. Proceedings Royal Society Biology 280, 1773.

Wedding LM, Reiter SM, Smith CR, Gjerde KM, KIttinger JN, Friedlander AM, Gaines SD, Clark MR, Thurnherr AM, Hardy SM, Crowder LB (2015) Managing mining of the deep seabed. Science 349, 6244, 144-145.

Wilson JB (1999) Assembly rules in plant communities. In: Weiher E, Keddy P (eds.) Ecological assembly rules: perspectives, advances, retreats. University Press, Cambridge, UK, pp 130-164.

Wilson JB, Roxburg SH (1994) A demonstration of guild-based assembly rules for a plant community, and determination of intrinsic guilds. Oikos 69, 267-276. 